\title{
Quantifying changes in ecological function of headwater catchments following large-scale surface mining in southern West Virginia
}

\author{
Gretchen Anne Gingerich \\ West Virginia University
}

Follow this and additional works at: https://researchrepository.wvu.edu/etd

\section{Recommended Citation}

Gingerich, Gretchen Anne, "Quantifying changes in ecological function of headwater catchments following large-scale surface mining in southern West Virginia" (2009). Graduate Theses, Dissertations, and Problem Reports. 2816.

https://researchrepository.wvu.edu/etd/2816

This Thesis is protected by copyright and/or related rights. It has been brought to you by the The Research Repository @ WVU with permission from the rights-holder(s). You are free to use this Thesis in any way that is permitted by the copyright and related rights legislation that applies to your use. For other uses you must obtain permission from the rights-holder(s) directly, unless additional rights are indicated by a Creative Commons license in the record and/ or on the work itself. This Thesis has been accepted for inclusion in WVU Graduate Theses, Dissertations, and Problem Reports collection by an authorized administrator of The Research Repository @ WVU. For more information, please contact researchrepository@mail.wvu.edu. 
Quantifying Changes in Ecological Function of Headwater Catchments Following Largescale Surface Mining in Southern West Virginia

\author{
Gretchen Anne Gingerich
}

Thesis submitted to the Davis College of Agriculture, Natural Resources, and Design at West Virginia University in partial fulfillment of the requirements for the degree of

Master of Science

in

Wildlife and Fisheries Resources

J. Todd Petty, Ph.D., Major Advisor

James T. Anderson, Ph.D., Committee Member

Paul F. Ziemkiewicz, Ph.D., Committee Member

Division of Forestry and Natural Resources

Morgantown, West Virginia

2009

Key words: decomposition, dissolved organic carbon, mitigation, ecological units, coal mining, amphibian colonization, macroinvertebrate colonization, surface mine reclamation, wetland creation, elevated conductivity and total dissolved solids

Copyright 2009 Gretchen Anne Gingerich 


\begin{abstract}
Quantifying Changes in Ecological Function of Headwater Catchments Following Largescale Surface Mining in Southern West Virginia

Gretchen Anne Gingerich
\end{abstract}

West Virginia is one of the leading producers of coal in the United States. Large scale surface mining (mountaintop removal mining, MTR) has become commonplace in $\mathrm{WV}$ as a technique for accessing thin layers of coal that may be difficult or impossible to access through traditional underground mining techniques. MTR disturbs large areas of land and often results in a complete rearrangement of headwater catchments. Although restoring original pre-mining conditions is ideal, it is usually unrealistic in this region. Consequently, the extent to which post-reclamation watersheds function relative to the pre-mining conditions is unclear. The objectives of this study were to 1) quantify the functional value of reference headwater streams and post-reclamation aquatic features, 2) determine whether ecological functions are adequately replaced after mining and reclamation, and 3) develop recommendations for mining reclamation and direction for future studies.

Typically during mining and reclamation, steep, forested, ephemeral and intermittent stream channels that existed pre-mining are replaced with unforested, gently rolling terrain. Intermittent and perennial aquatic channels develop along the mine perimeter. These channels are constructed as sediment control complexes during the mining and mine-reclamation process. These aquatic features remain on the landscape post-reclamation and were the focus of this study's functional evaluation. Elevated metal concentrations were observed during some seasons at some mined locations. Overall, however, the reclamation process appears to do a good job of controlling metal contamination in water runoff. Perimeter channels, however, produced significantly higher levels of alkalinity, calcium, iron, magnesium, sulfate, specific conductivity, and total dissolved solids (TDS). Previous studies have shown these parameters to have significant downstream impacts on aquatic communities. These parameters are difficult to treat on-site and may be best managed at a watershed scale through the protection of undisturbed headwater catchments.

Over time, the reclaimed perimeter channels become vegetated with obligate wetland species, creating a considerable difference between mined and reference channels with regard to vegetation assemblages, canopy cover, and aquatic habitat quality. Species richness of macroinvertebrates and amphibians remains comparable between mined and reference channels. However, there is a distinct shift from sensitive, lotic taxa to tolerant, lentic taxa.

Reclaimed perimeter channel sites have a reduced ability to breakdown organic matter (OM), most likely as a result of reduced mechanical abrasion and reduced microbial activity due to elevated conductivity. Nevertheless, mined channels have significantly higher OM retention than reference channels. Consequently, perimeter channels show significantly higher overall processing power than reference channels. In other words, OM that enters a perimeter channel is retained and processed locally at a higher rate, whereas a greater proportion of OM entering a reference channel is transported downstream before being processed. As a result of higher OM retention and 
processing power, perimeter channels exported significantly more winter dissolved organic carbon (DOC) than reference stream sites.

This study represents a snapshot of relatively young (3 to 20 year old) reclaimed sites. Changes in vegetation, from open grassland to closed canopy forests, are expected as plant succession occurs over time. In addition, leaching of soluble salts may moderate many of the noted parameters such as alkalinity and sulfate that constitute high TDS values. Still, little is known about the rates and controlling factors of temporal changes. Overall, a combination of on-site reclamation, off-site mitigation for lost structural components, and compensation at a watershed scale may be the best solution for shortcomings in current permitting and reclamation processes. Protecting native stream channels within mining-impacted watersheds would serve both as a source of dilute fresh water to compensate for alkaline drainage parameters and as a safeguard against the regional extinction of sensitive taxa.

Key words: decomposition, dissolved organic carbon, mitigation, ecological units, coal mining, amphibian colonization, macroinvertebrate colonization, surface mine reclamation, wetland creation, elevated conductivity and total dissolved solids 
Acknowledgements

Thanks are due to all who helped in the lab and field with data collection. Special thanks to Gabriel Strain for his assistance with amphibian sampling and identification. Thanks to the committee members for their guidance and to the Office of Surface Mining (OSM) for funding this study. Thanks to Gina Bays, Mitch Kalos, Alex Neal, Kenny Daniel, John McHale, and Randy Maggard for their assistance with this project. And thanks to George Merovich and Eric Merriam for assistance with R programming. 


\section{Table of Contents}

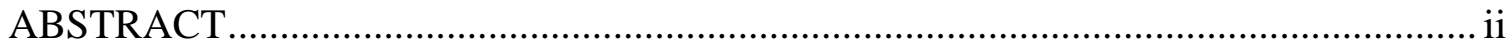



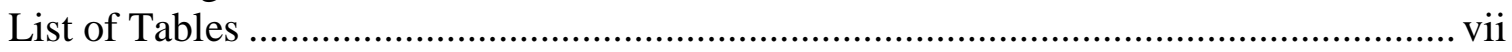

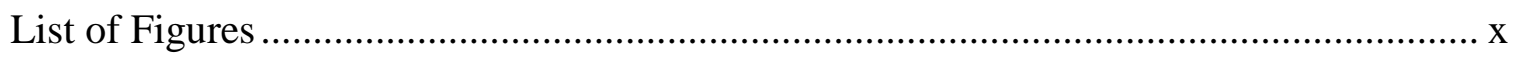

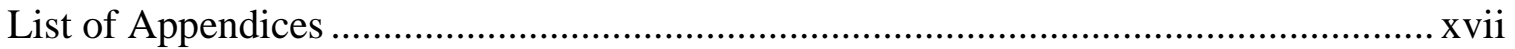

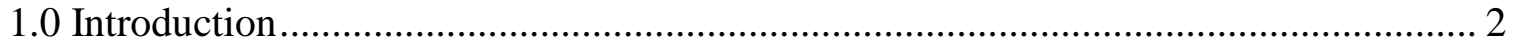

1.1 Surface Mining and Reclamation...................................................................... 2

1.2 Downstream Effects of Mining-related Disturbance ............................................... 2

1.3 Cumulative Impacts of Headwater Functional Losses .......................................... 5

1.4 Current Management Practices ........................................................................ 6

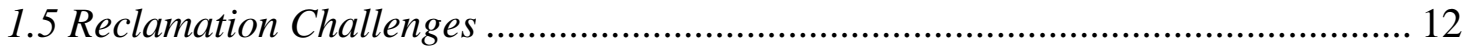

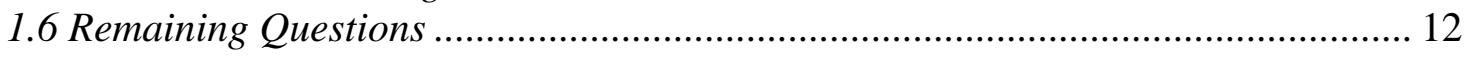

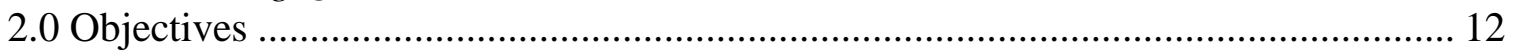



3.1 Study Area

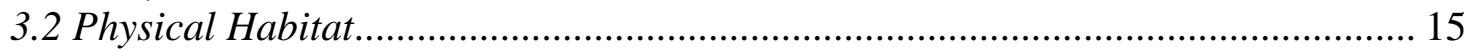

3.3 Water Chemistry, Temperature, and Discharge ................................................ 16

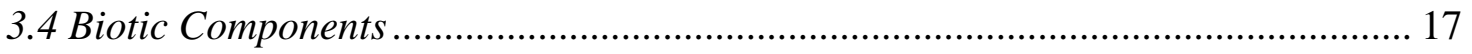

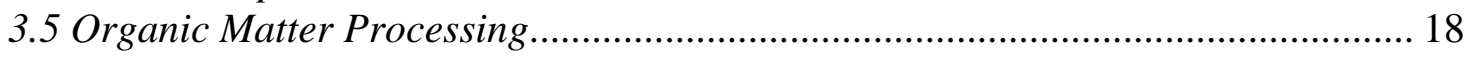

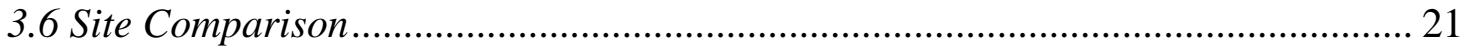

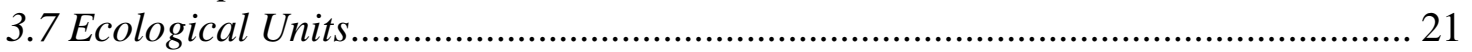

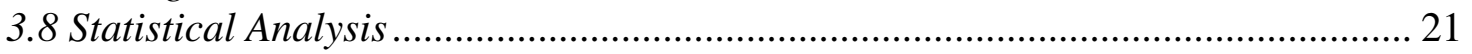



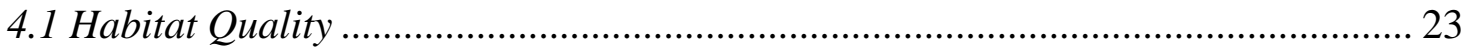

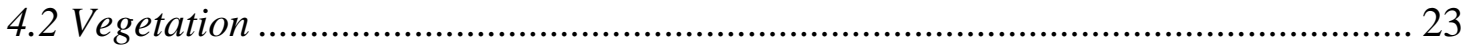

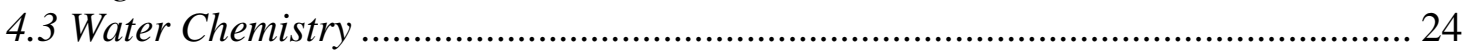

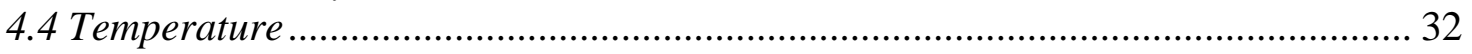

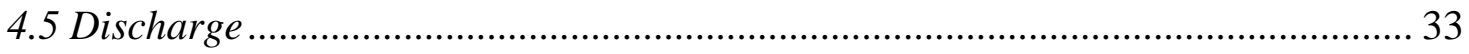

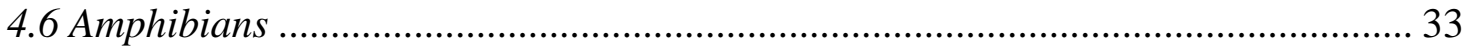

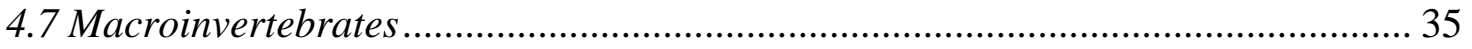

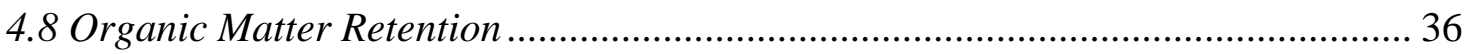

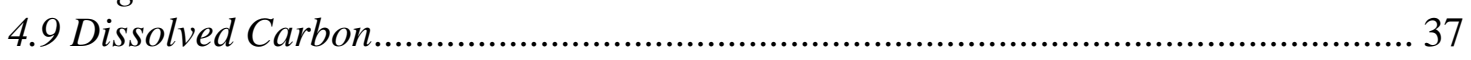



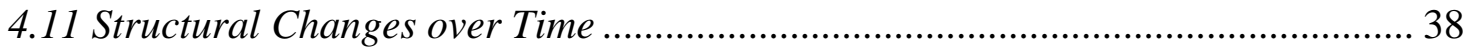

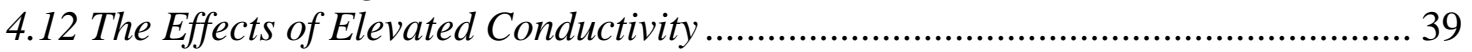





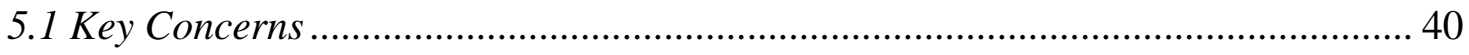

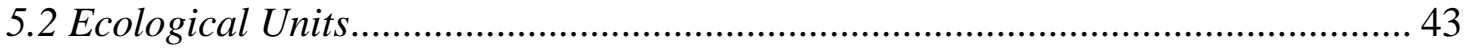

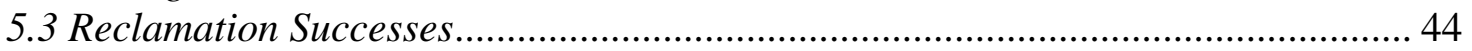

5.4 Are Ecological Functions Reclaimed Locally?.................................................... 49

5.5 Watershed Scale Perspective .............................................................................. 50

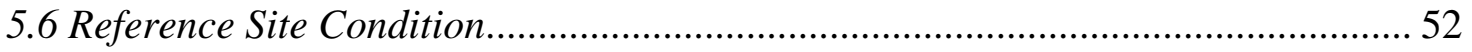

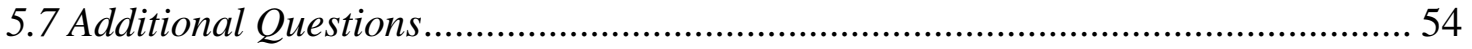



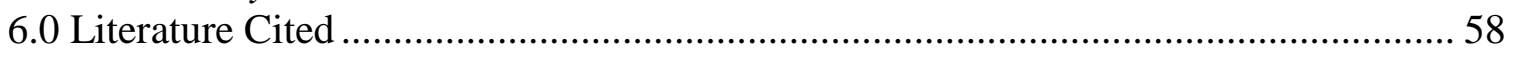






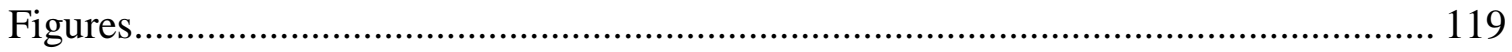




\section{List of Tables}

Table 1. Site name, site code, site type, approximate age, mean discharge, calculated drainage area (DA), and HUC 10 watershed (as defined by the Natural Resources Conservation Service), latitude and longitude in decimal degrees for reclaimed mine perimeter channels and reference streams. $\mathrm{P}=$ reclaimed mine perimeter channel. $\mathrm{R}=$ reference site. na $=$ not applicable.

Table 2. Sampled parameters for reclaimed mine perimeter channels and reference sites with sampling dates.

Table 3. Habitat assessment scores for reclaimed mine perimeter channels and reference streams. RBP $=$ Rapid Bioassessment Protocol, USM= Unified Stream Method, FCU= Functional Channel Unit Assessment, BEHI= Bank Erosion Hazard Index, and ORAM = Ohio Rapid Assessment Method. Mean and standard deviation by site type are given in the last two rows. Perimeter channel sites are listed in increasing age since reclamation. Statistical significance is indicated by $*=<0.05$.

Table 4. Mean and standard error for site types. Water chemistry means were calculated using $1 / 2$ the method detection limit (MDL) for values at MDL. T test statistics for means $*=<0.05, * *=<0.005, * * *=<0.001$.

Table 5. Percentage of vegetation from vegetation survey for reference sites and reclaimed mine perimeter channels. Mean and standard deviation by site type are given in the last two rows. Perimeter channel sites are listed in increasing age since reclamation. Statistical significance is indicated by $*=<0.05$.

Table 6. Percent canopy cover and tree count data for reference sites and reclaimed mine perimeter channels. Mean and standard deviation by site type are given in the last two rows. Perimeter channel sites are listed in increasing age since reclamation. Statistical significance is indicated by $*=<0.05$.

Table 7. Repeated measures ANOVA analysis of seasonal parameters for reclaimed mine perimeter channels and reference streams. Statistical significance is indicated by $*=<0.05, * *=<0.005, * * *=<0.001$.

Table 8. Temperature data $\left({ }^{\circ} \mathrm{C}\right)$ for reference sites and reclaimed mine perimeter channels for periods when streams contained water. Mean and standard deviation by site type are given in the last two rows. Perimeter channel sites are listed in increasing age since reclamation. No data were recovered from P_WO. Statistical significance is indicated by $*=<0.05, * *=<0.005, * * *=<0.001 \ldots 104$

Table 9. Amphibian abundance survey totals, for four sample periods, observed on reclaimed mine perimeter channels and reference sites. Frog and salamander species' preference for grassland or forest was based on information from Green and Pauley (1987). Mean and standard deviation by site type are given in the 
last two rows. Perimeter channel sites are listed in increasing age since reclamation. Statistical significance is indicated by $*=<0.05$.

Table 10. Larval amphibian biomass (g/100 ${ }^{2}$ ) for four sampling occasions observed on reclaimed mine perimeter channels and in reference sites. Mean and standard deviation by site type are given in the last two rows. Perimeter channel sites are listed in increasing age since reclamation. 106

Table 11. ANCOVA analysis of the effects of site type, conductivity, and their interaction on various ecological measures in reclaimed mine perimeter channels and reference sites. Degrees of freedom $=7$. Statistical significance is indicated by $*=<0.05, * *=<0.005, * * *=<0.001$.

Table 12. Combined larval and adult amphibian density (individuals $/ \mathrm{m}^{2}$ ) observed on reclaimed mine perimeter channels and reference sites for four sample periods. Mean and standard deviation by site type are given in the last two rows. Perimeter channel sites are listed by increasing age since reclamation. 108

Table 13. Frog and salamander species expected (Exp) to occur in grassland and forest in southwestern West Virginia, based on Green and Pauley (1987) compared to those actually observed (Obs) as (a) adults during visual encounter surveys (VES) (seen or heard), in (l) larval surveys, or (b) for both larval and VES. The preceding "p" indicates individuals encountered in perimeter sites and " $\mathrm{r}$ " indicates occurance within reference sites.

Table 14. Macroinvertebrate measurements from reclaimed mine perimeter channels and reference sites. Mean and standard deviation by site type are given in the last two rows. Perimeter channel sites are listed in increasing age since reclamation. Statistical significance is indicated by $*=<0.05$

Table 15. Percent of macroinvertebrates by feeding guild observed on reclaimed mine perimeter channels and reference sites. Guilds include collector gatherer (CG), filterer (FI), scraper (SC), shredder (SH), predator (PR), omnivore (OM), and unknown (UN). Mean and standard deviation by site type are given in the last two rows. Perimeter channel sites are listed in increasing age since reclamation. Statistical significance is indicated by $*=<0.05$

Table 16. Mean organic matter transport distances and retention rate for reclaimed mine perimeter channels and reference sites. Mean and standard deviation by site type are given in the last two rows. Perimeter channel sites are listed in increasing age since reclamation. Statistical significance is indicated by $*=$ $<0.05$.

Table 17. Dissolved organic carbon measures (mg/L) for reference sites and reclaimed mine perimeter channels. Reference sites did not contain water at the time of autumn sampling. Autumn samples for P_ST were contaminated. Site mean is the mean of spring, summer, and winter only. Mean and standard deviation by site type are given in the last two rows. Perimeter channel sites are listed in 
increasing age since reclamation. Statistical significance is indicated by *= $<0.05$.

Table 18. Total dissolved carbon measures (mg/L) for reference sites and reclaimed mine perimeter channels. Reference sites did not contain water at the time of autumn sampling. Autumn samples for P_ST were contaminated. Site mean is the mean of spring, summer, and winter only. Mean and standard deviation by site type are given in the last two rows. Perimeter channel sites are listed in increasing age since reclamation. Statistical significance is indicated by *= $<0.05$.

Table 19. Mean total weight (g), mean organic (g) and inorganic mass (g), percent organic, percent organic mass lost, decomposition rate $(\mathrm{k})$. and processing power observed on reclaimed mine perimeter channels and reference sites after 325 days of exposure. Mean and standard deviation by site type are given in the last two rows. Perimeter channel sites are listed in increasing age since reclamation. Statistical significance is indicated by $*=<0.05$.

Table 20. Correlation of parameters with decomposition rates and mean conductivity for reference sites and reclaimed mine perimeter channels. Mean and standard error are given in the first two rows

Table 21. Ecological units (EU) ratios, EU $\mathrm{I}_{\mathrm{I}}$ ratios (calculated using ideal reference means), perimeter means, reference means, and ideal reference means for reclaimed mine perimeter channels and reference sites. Species parameters are standardized by the area of aquatic feature sampled. 


\section{List of Figures}

Figure 1. Site locations and HUC 12 watersheds for reference sites (gray dots) and perimeter channels (black dots).

Figure 2. A.) A typical headwater system: two ephemeral streams (dotted line) feeding into an intermittent (dashed line), feeding into a perennial (solid line), and finally to a broad river. B.) A series of sediment ponds, or wetlands, on the perimeter of a valley-fill system. This system usually has an intermittent or perennial outflow off-site to a larger system.

Figure 3. Directly comparable and indirectly comparable site parameters for reference and reclaimed surface mine sites.

Figure 4. Seasonal $\mathrm{pH}$ for reclaimed mine perimeter channels and reference streams combined by site type. A range of $\mathrm{pH}$ 6.0-8.0 (dashed lines) is considered normal or acceptable.

Figure 5. Seasonal dissolved oxygen $(\mathrm{mg} / \mathrm{L})$ for reclaimed mine perimeter channels and reference streams combined by site type. A limit of $5.0 \mathrm{mg} / \mathrm{L}$ (dashed line) is recommended for the health of aquatic life.

Figure 6. Seasonal manganese (mg/L) for reclaimed mine perimeter channels and reference streams combined by site type. The WWF limit is $1 \mathrm{mg} / \mathrm{L}$ (dashed line). Method detection limits (MDL) were $0.017 \mathrm{mg} / \mathrm{L}$. Reference sites did not contain enough water for sampling in autumn.

Figure 7. Seasonal iron (mg/L) for reclaimed mine perimeter channels and reference streams combined by site type. A limit of $1.0 \mathrm{mg} / \mathrm{L}$ is recommended for the health of aquatic life (dashed line). Reference sites did not contain enough water for sampling in autumn.

Figure 8. Seasonal zinc (mg/L) for reclaimed mine perimeter channels and reference streams combined by site type. MDL was $0.016 \mathrm{mg} / \mathrm{L}$ (dotted line). The recommended level for the health of aquatic life is $0.04 \mathrm{mg} / \mathrm{L}$ (dashed line). Reference sites did not contain enough water for sampling in autumn.

Figure 9. Seasonal selenium (mg/L) for reclaimed mine perimeter channels and reference streams combined by site type. The WWF limit is $0.005 \mathrm{mg} / \mathrm{L}$ (dashed line). MDL was $0.045 \mathrm{mg} / \mathrm{L}$ (dotted line). Reference sites did not contain enough water for sampling in autumn.

Figure 10. Seasonal nitrite (mg/L) for reclaimed mine perimeter channels and reference streams combined by site type. R_HC experienced a summer measure of $46.230 \mathrm{mg} / \mathrm{L}$ (not shown) after disturbance. Reference sites did not contain enough water for sampling in autumn. 
Figure 11. Seasonal nitrate (mg/L) for reclaimed mine perimeter channels and reference streams combined by site type. The WWF limit is $90 \mathrm{mg} / \mathrm{L}$ (dashed line). Reference sites did not contain enough water for sampling in autumn.

Figure 12. Seasonal total phosphorus (mg/L) for reclaimed mine perimeter channels and reference streams combined by site type. In 1986, EPA recommended a 0.1 $\mathrm{mg} / \mathrm{L}$ limit for streams not emptying into reservoirs. Reference sites did not contain enough water for sampling in autumn.

Figure 13. Seasonal barium (mg/L) for reclaimed mine perimeter channels and reference streams combined by site type. Reference sites did not contain enough water for sampling in autumn.

Figure 14. Seasonal ammonia (mg/L) for reclaimed mine perimeter channels and reference streams combined by site type. The recommended limit for aquatic life health is $0.05 \mathrm{mg} / \mathrm{L}$ (dashed line). Reference sites did not contain enough water for sampling in autumn.

Figure 15. Seasonal cobalt (mg/L) for reclaimed mine perimeter channels and reference streams combined by site type. There is no recommended limit for aquatic health. MDL was $0.015 \mathrm{mg} / \mathrm{L}$ (dotted line). Reference sites did not contain enough water for sampling in autumn.

Figure 16. Seasonal copper $(\mathrm{mg} / \mathrm{L})$ for reclaimed mine perimeter channels and reference streams combined by site type. The WWF limit is $0.006 \mathrm{mg} / \mathrm{L}$ (dashed line). MDL was $0.015 \mathrm{mg} / \mathrm{L}$ (dotted line). Reference sites did not contain enough water for sampling in autumn.

Figure 17. Seasonal cadmium (mg/L) for reclaimed mine perimeter channels and reference streams combined by site type. The WWF limit is $0.007 \mathrm{mg} / \mathrm{L}$ (dashed line). However, method detection limit (MDL) was 0.014 (dotted line). Reference sites did not contain enough water for sampling in autumn. 135

Figure 18. Seasonal acidity (mg/L) for reclaimed mine perimeter channels and reference streams combined by site type. Reference sites did not contain enough water for sampling in autumn. 136

Figure 19. Seasonal alkalinity (mg/L) for reclaimed mine perimeter channels and reference streams combined by site type. An alkalinity of $>20 \mathrm{mg} / \mathrm{L}$ (dashed line) is considered to have good buffering capacity. Reference sites did not contain enough water for sampling in autumn.

Figure 20. Seasonal calcium (mg/L) for reclaimed mine perimeter channels and reference streams combined by site type. Reference sites did not contain enough water for sampling in autumn.

Figure 21. Seasonal magnesium (mg/L) for reclaimed mine perimeter channels and reference streams combined by site type. Streams with magnesium sources 
usually have levels of 5-50 mg/L (dashed lines). Reference sites did not contain enough water for sampling in autumn.

Figure 22. Seasonal sulfate $(\mathrm{mg} / \mathrm{L})$ for reclaimed mine perimeter channels and reference streams combined by site type. Perimeter sites measured above $250 \mathrm{mg} / \mathrm{L}$ (dashed line). Reference sites did not contain enough water for sampling in autumn....

Figure 23. Seasonal chromium (mg/L) for reclaimed mine perimeter channels and reference streams combined by site type. The WWF limit for chromium is 0.01 $\mathrm{mg} / \mathrm{L}$ (dashed line). MDL was $0.012 \mathrm{mg} / \mathrm{L}$ (dotted line). Reference sites did not contain enough water for sampling in autumn...

Figure 24. Seasonal conductivity $(\mu \mathrm{S} / \mathrm{cm})$ for reclaimed mine perimeter channels and reference streams combined by site type. A conductivity of $500 \mu \mathrm{S} / \mathrm{cm}$ (dashed line) is the EPA recommended upper limit for healthy fisheries.

Figure 25. The percent of mean TDS that was composed of bicarbonate, calcium, magnesium, sulfate, chloride, and sodium for reclaimed surface mine perimeter channel and reference sites. Perimeter channels are presented in order of age since reclamation.

Figure 26. Seasonal aluminum (mg/L) for reclaimed mine perimeter channels and reference streams combined by site type. The WWF limit is $0.75 \mathrm{mg} / \mathrm{L}$ (dashed line). Method detection limits (MDL) were $0.021 \mathrm{mg} / \mathrm{L}$ (dotted line). Reference sites did not contain enough water for sampling in autumn.

Figure 27. Seasonal nickel (mg/L) for reclaimed mine perimeter channels and reference streams combined by site type. Method detection limit (MDL) was $0.019 \mathrm{mg} / \mathrm{L}$ (dotted line). The WWF limit is $0.088 \mathrm{mg} / \mathrm{L}$ (dashed line). Reference sites did not contain enough water for sampling in autumn.

Figure 28. Seasonal chloride (mg/L) for reclaimed mine perimeter channels and reference streams combined by site type. Recommended limit for the protection of aquatic life is $600 \mathrm{mg} / \mathrm{L}$. R_HC experienced a summer measure of 1070.73 mg/L (not shown) after disturbance. Reference sites did not contain enough water for sampling in autumn.

Figure 29. Seasonal sodium (mg/L) for reclaimed mine perimeter channels and reference streams combined by site type. Perimeter channels measured above $20 \mathrm{mg} / \mathrm{L}$ (dashed line). Summer R_HC measured $293.22 \mathrm{mg} / \mathrm{L}$ (not shown). Reference sites did not contain enough water for sampling in autumn.

Figure 30. Mean daily temperature for reclaimed mine perimeter channels $(\mathrm{P})$ and reference sites $(\mathrm{R})$ during periods when streams contained water. The mean of these temperatures is $11.7^{\circ} \mathrm{C}$ (dashed line). 
Figure 31. Maximum daily temperature for reclaimed mine perimeter channels $(\mathrm{P})$ and reference sites $(\mathrm{R})$ during periods when streams contained water. The mean of these temperatures is $22.9^{\circ} \mathrm{C}$ (dashed line).

Figure 32. Minimum daily temperature for reclaimed mine perimeter channels (P) and reference sites $(\mathrm{R})$ during periods when streams contained water. The mean of these temperatures is $4.7^{\circ} \mathrm{C}$ (dashed line).

Figure 33. Seasonal discharge $\left(\mathrm{m}^{3} / \mathrm{s}\right)$ for reclaimed mine perimeter channels and reference streams combined by site type. The mean discharge is $0.0057 \mathrm{~m}^{3} / \mathrm{s}$ (dashed line).

Figure 34. Mean amphibian density and standard error on reclaimed mine perimeter channels and reference sites determined from amphibian abundance surveys performed on four sample dates. Perimeter channel sites are listed in increasing age since reclamation. Perimeter channel sites are shown in black, and reference channel sites are shown in gray. 152

Figure 35. NMDS ordination analysis distinguishing site type by amphibian community data with overlaying significant vegetation vectors. Vegetation vectors include percent open water, grass, cattail, bare ground, percent canopy cover (Pct.Canopy.Cover), fern, and species per $\mathrm{km}^{2}$. The direction of the vector indicates the direction of influence the vector has on determining community composition. The size of the character indicates the species richness of the site with larger characters indicating sites with greater richness.

Figure 36. NMDS ordination analysis distinguishing site type by amphibian community data with overlaying significant water chemistry vectors. The direction of the vector indicates the direction of influence the vector has on determining community composition. Vector measures include mean conductivity (Cond), sulfate $\left(\mathrm{SO}_{4}\right)$, magnesium (Mg), mean total dissolved solids (Avg.TDS), calcium (Ca), alkalinity (Alk), and iron (Fe). The size of the character indicates the species richness of the site with larger characters indicating sites with greater richness.

Figure 37. Mean conductivity versus amphibian species richness for four sampling periods. Reclaimed mine perimeter channel sites are represented by black triangles and dotted regression line. Reference sites are represented by black circles and solid regression line.

Figure 38. Mean conductivity versus the total number of larval amphibian species for four sampling periods. Reclaimed mine perimeter channel sites are represented by black triangles and dotted regression line. Reference sites are represented by black circles and solid regression line. 156

Figure 39. Mean conductivity versus the total number of larval amphibians captured during four amphibian sampling periods. Reclaimed mine perimeter channel 
sites are represented by black triangles and dotted regression line. Reference sites are represented by black circles and solid regression line.

Figure 40. Mean conductivity versus mean percentage of amphibian species present that utilize lotic habitat. Reclaimed mine perimeter channel sites are represented by black triangles and dotted regression line. Reference sites are represented by black circles and solid regression line. 158

Figure 41. Mean conductivity versus the percentage of amphibian species present, during four sampling periods, that utilize forest habitat. Reclaimed mine perimeter channel sites are represented by black triangles and dotted regression line. Reference sites are represented by black circles and solid regression line.

Figure 42. Mean conductivity versus the percentage of amphibian species present that utilize grassland habitat. Reclaimed mine perimeter channel sites are represented by black triangles and dotted regression line. Reference sites are represented by black circles and solid regression line.

Figure 43. Mean conductivity versus WVSCI score for the spring 2008 sampling period. Reclaimed mine perimeter channel sites are represented by black triangles and dotted regression line. Reference sites are represented by black circles and solid regression line.

Figure 44. Mean conductivity versus percent EPT for the spring 2008 sampling period. Reclaimed mine perimeter channel sites are represented by black triangles and dotted regression line. Reference sites are represented by black circles and solid regression line.

Figure 45. Mean conductivity versus EPT species richness for the spring 2008 sampling period. Reclaimed mine perimeter channel sites are represented by black triangles and dotted regression line. Reference sites are represented by black circles and solid regression line.

Figure 46. Mean conductivity versus percentage of shredders for the spring 2008 sampling period. Reclaimed mine perimeter channel sites are represented by black triangles and dotted regression line. Reference sites are represented by black circles and solid regression line

Figure 47. NMDS ordination analysis distinguishing site type by macroinvertebrate community data with overlaying significant environmental vectors. The direction of the vector indicates the direction of influence the vector has on determining community composition. Vector measures include $\mathrm{NH}_{3}$, mean summer discharge (Avg.Summer.Q), and selenium (Se). The size of the site character indicates the family richness of the site with larger characters indicating sites with greater richness.

Figure 48. NMDS ordination analysis distinguishing site type by macroinvertebrate community data with Spearman rank correlations are annotated along each axis. 
The size of the site character indicates the species richness of the site with larger characters indicating sites with greater richness.

Figure 49. Seasonal DOC measurements for reclaimed mine perimeter channels and reference sites combined by site type. Mean DOC is $2.60 \mathrm{mg} / \mathrm{L}$ (dashed line). Reference sites did not contain enough water for autumn sampling. 167

Figure 50. Mean total carbon for reclaimed mine perimeter channels and reference sites given by concentration of dissolved organic carbon (DOC) and inorganic carbon (IC). Perimeter channel sites are listed in increasing age since reclamation. . 168

Figure 51. Mean percent organic mass lost from original leaf litter inputs after 325 days of exposure on reclaimed mine perimeter channels and reference sites. Perimeter channel sites are listed in order of increasing age since reclamation. Perimeter channel sites are shown in black and reference channel sites are shown in gray.

Figure 52. Decomposition rate (-k) of Quercus palustris (pin oak) leaf litter on reclaimed mine perimeter channels and reference streams after $\sim 325$ days of exposure. Perimeter channel sites are listed in increasing age since reclamation. Perimeter channel sites are shown in black and reference channel sites are shown in gray.

Figure 53. Mean conductivity versus mean percent organic mass lost from leaf litter packs after 325 days. Reclaimed mine perimeter channel sites are represented by black triangles and dotted regression line. Reference sites are represented by black circles and solid regression line.

Figure 54. Mean conductivity versus mean percent organic matter composition in leaf litter packs after 325 days. Reclaimed mine perimeter channel sites are represented by black triangles and dotted regression line. Reference sites are represented by black circles and solid regression line.

Figure 55. Mean conductivity versus mean total weight of leaf litter packs after 325 days. Reclaimed mine perimeter channel sites are represented by black triangles and dotted regression line. Reference sites are represented by black circles and solid regression line.

Figure 56. Mean sodium (mg/L) levels for reclaimed mine perimeter channel sites in order of age since reclamation. Confidence interval for reference sites (-16.7 $71.1 \mathrm{mg} / \mathrm{L}$ ) is not shown.

Figure 57. Mean conductivity $(\mu \mathrm{S} / \mathrm{cm})$ levels for reclaimed mine perimeter channel sites in order of age since reclamation. Confidence interval for reference sites (-179 $-1101 \mu \mathrm{S} / \mathrm{cm}$ ) is shown (dotted line).

Figure 58. Percent cattail for reclaimed mine perimeter channel sites in order of age since reclamation. Confidence interval for reference sites was zero. 
Figure 59. Trees per $\mathrm{km}^{2}$ for reclaimed mine perimeter channel sites in order of age since reclamation. Confidence interval for reference sites $(4.8-13.5)$ is not shown.

Figure 60. Total invertebrate richness for reclaimed mine perimeter channel sites in order of age since reclamation. Confidence interval for reference sites (5 - 9) is

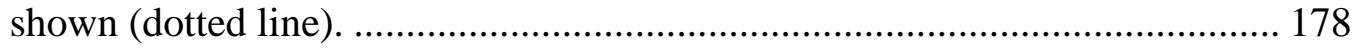

Figure 61. Percent tolerant invertebrates for reclaimed mine perimeter channel sites in order of age since reclamation. Confidence interval for reference sites (17 - 67) is shown (dotted line)

Figure 62. Percent grassland amphibians for reclaimed mine perimeter channel sites in order of age since reclamation. Confidence interval for reference sites (0) is not shown. 180 


\section{List of Appendices}

Appendix A. Seasonal water chemistry measures for reference sites and reclaimed mine perimeter channels. Reference sites did not contain enough water for sampling during autumn. MDL= method detection limit. Mean and standard deviation by site type are given in the last two rows. Perimeter channel sites are listed in increasing age since reclamation.

Appendix B. Seasonal temperature data for reference sites and perimeter channels for periods when streams contained water. Mean and standard deviation by site type are given in the last two rows. Perimeter channel sites are listed in order of increasing age since reclamation.

Appendix C. Adult amphibian abundance totals observed on reclaimed mine perimeter channels and reference streams for four sample periods. Totals by site type are given in the last two columns. Totals by site are given in the last two rows. Perimeter channel sites are listed in increasing age since reclamation.

Appendix D. Larval amphibian abundance survey totals observed on reclaimed mine perimeter channels and reference streams for four sample periods. Totals by site type are given in the last two columns. Totals by site are given in the last two rows. Perimeter channel sites are listed in increasing age since reclamation.

Appendix E. Combined larval and adult amphibian abundance survey totals observed on reclaimed mine perimeter channels and reference sites for four sample periods. Totals by site type are given in the last two columns. Totals by site are given in the last two rows. Perimeter channel sites are listed in order of increasing age since reclamation.

Appendix F. Macroinvertebrate abundance data given by Order (when known) for reclaimed mine perimeter channels and reference sites. Mean and standard deviation by site type are given in the last two columns. Perimeter channel sites are listed in order of increasing age since reclamation.

Appendix G. Macroinvertebrate abundance data given as a percent by Order (when known) for reclaimed mine perimeter channels and reference streams. Mean and standard deviation by site type are given in the last two columns. Perimeter channel sites are listed in order of increasing age since reclamation.

Appendix H. Macroinvertebrate abundance data given by Genus (when known) for reclaimed mine perimeter channels and reference streams. Mean and standard deviation by site type are given in the last two columns. Perimeter channel sites are listed in order of increasing age since reclamation. 


\title{
Chapter 1
}

Quantifying Changes in Ecological Function of Headwater Catchments Following Largescale Surface Mining in Southern West Virginia

\section{Gretchen Anne Gingerich ${ }^{1}$}

\author{
J. Todd Petty ${ }^{2}$
}

${ }^{1}$ Division of Forestry and Natural Resources, Wildlife and Fisheries Resources Program, West Virginia University, PO Box 6125, Percival Hall, Morgantown, WV 26506

2 address correspondence to J. Todd Petty, Ph.D., Division of Forestry and Natural Resources, Wildlife and Fisheries Resources Program, West Virginia University, PO Box 6125, Percival Hall, Morgantown, WV 26506. email: jtpetty@wvu.edu phone: (304) 293-2278 fax: (304) 293-2441

Submitted in the style of:

Restoration Ecology 


\subsection{Introduction}

\subsection{Surface Mining and Reclamation}

West Virginia is a leading producer of coal in the United States. Effectively managing the development of large-scale surface mines in southern West Virginia may be one of the most pressing environmental issues in the United States at this time. Large scale surface mining, commonly known as mountaintop removal mining (MTR), generates substantial volumes of excess spoil which are placed in external fills, permanently altering headwater streams. Individual fills may range from less than 25 hectares to hundreds of hectares and extend for thousands of meters in the watershed. The West Virginia Department of Environmental Protection (WVDEP) Code of State Rules stipulates “...no significant adverse impact to the chemical, physical, hydrologic, or biological components of aquatic ecosystems shall be allowed” (WVDEP 2007). Despite reclamation efforts, there remains considerable uncertainty over whether aquatic features on reclaimed mines are fulfilling Clean Water Act standards or are effective in recovering lost headwater functions.

\subsection{Downstream Effects of Mining-related Disturbance}

Several studies have been conducted on the effects of large-scale disturbances including deforestation, urbanization, and mining. There is some agreement about the general effects of these on local hydrology. Generally expected is an increase in runoff, stream flashiness, nutrients, relative abundance of exotic species, erosion potential, conductivity, sedimentation, metals, discharge, totals suspended and dissolved solids, and temperature (Likens et al. 1970, Dick et al. 1983, Martin et al. 1984, Bonta 2000, Tiwary 
2001, Wiley et al. 2001, Bonta \& Dick 2003, Wiley \& Brogan 2003, USEPA 2005, Hartman et al. 2005, Maloney 2005, Meyer et al. 2005). Additionally, a decrease in organic matter export, streambed stability, macroinvertebrate richness and diversity, and pH may also be expected (Likens et al. 1970, Dick et al. 1983, Blevins 1991, Hartman et al. 2005, Maloney 2005, Meyer et al. 2005, Pond et al. 2008).

One of the largest issues resulting from disturbance caused by surface mining is the increase in total dissolved solids (TDS), salinity, and specific conductivity (all of which are highly correlated) in the resulting surface and groundwater. Efforts to remove or reduce TDS focus mainly on creating settlement ponds. Often the size of the sediment pond is significant enough to allow intentional or un-intentional hydrophytic vegetation growth. High TDS may negatively influence the biota of an aquatic feature. Spieles and Mitsch (2000) found that mean diel dissolved oxygen and specific conductivity were the best environmental predictors of invertebrate community metrics. Elevated conductivity, particularly, has been shown to interfere with the osmoregulation of macroinvertebrates (Wichard 1973, McCulloch 1993). Specific conductivity explained $16.4 \%$ of the differences in community structure (Spieles \& Mitsch 2000). Ephemeroptera, specifically, have been shown to display the greatest response to increases in specific conductivity in waters affected by surface mining within the Appalachian region (Hartman et al. 2005, Pond et al. 2008).

Threat from acid mine drainage (AMD) exists when the pyritic minerals in coal and overburden are exposed to water and oxygen. The water leaving these sites is often highly acidic with high sulfate and monomeric aluminum concentrations (Baker et al. 
1996, Merovich et al. 2007). When this water enters native catchments, aquatic ecosystems experience biological degradations such as altered periphyton community (Meegan \& Perry 1996), reduced macroinvertebrate species richness, density, and biomass (Krueger \& Waters 1983), and altered fish community assemblage (Krueger \& Waters 1983, Baker et al. 1996, McClurg et al. 2007).

Macroinvertebrates are ubiquitous in natural settings and display diverse responses to environmental stresses. In part because of the community response, the analysis of benthic macroinvertebrates is generally accepted as a good measure of stream health (Purcell et al. 2002, Merovich \& Petty 2007). Mining related impacts have been shown to result in a degradation of macroinvertebrate community structure and shifts in community composition primarily through an overall reduction in sensitive macroinvertebrate taxa (Garcia-Criado et al. 1999, Kennedy et al. 2003, Pond et al. 2008, Merriam 2009).

MTR and valley fill construction have also been shown to result in general degradation of stream fish communities. Stauffer and Ferreri (2002) found reduced fish species and reduced benthic fish species after mining-related impacts. Fulk et al. (2003) also found a reduction in overall Index of Biotic Integrity (IBI) scores in sites associated with mining. This was largely due to a reduction in minnow species and benthic insectivores.

Despite documented negative impacts of mining to downstream ecosystems and water quality, debate ensues over whether these impacts could, or should, be considered sources of impairment. 


\subsection{Cumulative Impacts of Headwater Functional Losses}

Broad concern also exists over the effects of cumulative loss of headwater ecosystem functions from multiple mined watersheds. Over time, the cumulative effects of loss of headwater functions could cause unacceptable impacts to larger waterbodies downstream (Zedler 2003, USEPA 2005).

Previous literature has emphasized the connectivity of upstream functional and ecological processes to downstream ecosystem function and value (Vannote et al. 1980, Gomi et al. 2002, Lowe et al. 2006, Meyer et al. 2007, Wipfli et al. 2007). Generally, the ecological functions of individual headwater streams include the transport of invertebrates and organic matter and providing important trophic linkages (Wipfli 2005). Allochthonous headwater streams form an essential linkage in energy flow from upland forested watersheds to broad, turbid rivers downstream (Vannote et al. 1980). Fisher and Likens (1973) estimated that 66\% of the annual energy budget of a second order stream was exported downstream. Native channels act as a source of coarse and fine particulate organic matter (CPOM/FPOM) for downstream trophic webs (Cummins \& Klug 1979, Vannote et al. 1980, Cummins et al. 1989, Wallace et al. 1997). The losses of these energy sources may negatively affect overall productivity in downstream habitats.

Headwaters also act as refugia and source populations for downstream assemblages (Lowe \& Bolger 2002, Meyer at al. 2007). Disturbed sites often benefit from the presence of these undisturbed sites as a source of re-colonization (Brown \& Kodricbrown 1977). However, re-colonization may be affected by both the extent of the watershed affected and to the life histories of at-risk species to determine regional habitat 
needs (Lowe et al. 2006). Ensuring the connectivity of first-order streams may be essential for ensuring the survival of some species, such as Gyrinophilus porphyriticus (spring salamander) (Lowe \& Bolger 2002, Lowe et al. 2006).

Additionally, the watershed-scale cumulative effects of mining may be confounded by the presence of other stressors within the watershed. Merriam (2009) found additive negative effects of mining and residential development on water chemistry and habitat degradation. Some studies show no cumulative effects of mining within watersheds on factors such as macroinvertebrate community structure (Fulk et al. 2003, Pond et al. 2008). However, studies have documented significant relationships between the density of mining within a watershed and the degradation of physical, chemical and biological conditions in streams (Maret \& MacCoy 2002, Maret et al. 2003, Bruns et al. 2005). Although there is potential for such effects, the reality of this concern is currently largely undocumented.

\subsection{Current Management Practices}

Management techniques and best management practices (BMPs) exist to manage mining related impacts such as AMD production, sediment control, loss of vegetation, and increased concentration of water chemistry parameters. AMD is largely avoided both by restriction in the permitted locations of coal extraction and by material handling BMPs (Johnson \& Hallberg 2005). Historically produced AMD is commonly mitigated for using limestone treatments (Weatherley 1988, McClurg et al. 2007).

On-site reclamation is often used to prevent, or lessen, potential downstream impacts. The purpose of reclamation is to improve the quality of the land by restoring 
pre-disturbance function (Bradshaw 1984). Additionally, reclamation seeks to reduce threats to downstream ecosystems such as impairment in water chemistry, channel sedimentation, impairment of riparian vegetation and aquatic habitat, and alteration to hydrology (primarily to peak flows) (Halverson \& Sidel 1997). Surface mine reclamation became mandated in 1977 with the passage of the Surface Mining Control and Reclamation Act (SMRCA). Since that time, return of the site slopes to approximate the original contours and re-vegetation of the site to "a diverse, effective, and permanent vegetative cover of the same seasonal variety and native to the area and capable of selfregeneration and plant succession" within 5 years of mining has been required for bond release. Additionally, in terms of function, SMRCA requires "those actions taken to restore mined land to a post-mining land use approved by the Division of Mined Land Reclamation.” Reclamation, however, does not imply the return of an ecosystem to an original state but does imply return to a functional state (Bradshaw 1996).

\section{Erosion Control}

According to Nicolau (2003), reproduction of the original topography of an area during reclamation is considered the geomorphic ideal; however, it is not always appropriate in steeper areas. Most surface mining in West Virginia occurs in steep, forested, headwater areas. Mining and filling these areas removes the forested cover and may alter the gradient. In the case of mountain top removal mining, steep, forested headwater streams are replaced by herbaceous vegetation, unconsolidated fill, and erosion control features. Typical erosion control consists of boulder-filled groin ditches and perimeter sediment ponds. These sediment ponds may be isolated or connected in 
series. They may or may not have downstream outflows. Often the size of the sediment pond is significant enough to allow intentional or un-intentional hydrophytic vegetation growth. Atkinson and Cairns (1994) found that of 14 "accidentally-formed" wetlands in a coal mined area in the Appalachians, all contained at least 26 obligate wetland plant species.

Although some studies have recommended both revegetation and removal of sediment ditches to reduce chemical load rates after reclamation (Bonta \& Dick 2003), other authors encourage wetland construction in mined areas (Wieder \& Lang 1984, Cole \& Lefebvre 1991, Atkinson \& Cairns 1994, Horstman et al. 1998). In several studies, constructed wetlands, particularly emergent wetlands, were found to support substantial waterfowl, anuran, and macroinvertebrate diversity (Horstman et al. 1998, Balcombe et al. 2005a,b). Wetlands were also found to be sinks for nitrogen, phosphorus, and carbon depending on their location in the watershed, residence time of water, and the volume of discharge (Raisin et al. 1997, Whiting \& Chanton 2001). Results suggest rapid recovery of a watershed from disturbance. Constructed wetlands, in particular, demonstrate the botanical and biogeochemical characteristics of natural wetlands within a short time (less than 10 years), perhaps even within three to four years (Cole \& Lefebvre 1991, Karamat et al. 1998, Maloney 2005). However, many would argue that a substantially longer period is more likely (Roberts 1993, Malakoff 1998, Zedler 2004).

\section{Water Quality}

Increasingly, retention ponds, or wetlands, are constructed in hopes of reducing unwanted water quality parameters such as dissolved metals (Sobolewski 1999). 
Wetlands have been shown to be effective at removing aluminum, arsenic, cadmium, cobalt, copper, cyanide, iron, lead, manganese, nickel, uranium, and zinc (Sobolewski 1999). Sobolewski (1999) found that shallow depth and large inputs of organic matter were key characteristics of wetlands effective at removing metals from the water column. Aquatic macrophytes play an essential role in removing metals from the water column by creating an environment suitable for metal removal (Brix 1994); but macrophyte removal usually accounts for only a minor proportion of total mass removed (Sobolewski 1999). Of macrophytes that are known to volunteer-establish on reclaimed and abandoned surface mines, Jones et al. (1993) found the average number of species per site was 18 with a maximum of 34 and a minimum of 7 . Of those species, the rank of importance by cover and frequency placed Typha sp., Scirpus cyperinus, Juncus acuminatus, and Juncus effusus in the top four. Fortunately, metal removal by wetland ecosystems is not restricted to a particular plant species or climate (Prasad \& Freitas 1999, Sobolewski 1999). Sobolewski (1999) did find that the $\mathrm{pH}$ of the drainage itself may influence the effectiveness of the wetland at removing metals, with acidic drainage impeding metal removal.

Microbial activity within the wetland plays an important role in metal removal (Sobolewski 1999). Microbial activity, combined with oxygen released from plant roots, creates an environment containing both aerobic and anaerobic conditions that allows for oxidation and reduction reactions simultaneously within the same location (Brix 1994). This allows metals to be removed from solution and retained in the sediments in stable, biologically unavailable forms (Sobolewski 1999). 


\section{$\underline{\text { Restoring Vegetation }}$}

Obstacles to establishing vegetation on mined sites include low $\mathrm{pH}$ (Haufler et al. 1978, Stocum 1980), soil compaction (Daniels \& Amos 1981), elevated surface temperatures (Deely \& Borden 1973, Stocum 1980, Bell \& Unger 1981), and lack of nutrients such as nitrogen and phosphorus (Haufler et al. 1978, Andrews 1992). Additionally, colonization by native plants may be hindered by distance to intact forests and sources of seed, soil compaction by machinery (Davison et al. 1984), and competition by intentionally planted non-native plants (Connell \& Slatyer 1977). After 35 years post mining, Holl (2002) found reclaimed mine sites differed substantially from reference sites in terms of vegetation.

Depending on the species, initial vegetation establishment may either encourage, not effect, or inhibit additional species establishment (Connell \& Slatyer 1977). Reclaimed sites are often seeded with rapidly growing non-native species, such as the grass Festuca arundinacea, for erosion control purposes. These species may hinder succession by native species and overall ecosystem recovery (Brenner et al. 1984, Burger \& Torbet 1990, Hughes 1992, Chambers et al. 1994, Holl \& Cairns 1994, Skousen et al. 1994, Torbet et al. 2000, Allen et al. 2001, Skousen et al. 2006).

Reclaimed mine sites are often planted with Pinus strobus (eastern white pine), a pine often native to mined catchments. Although $P$. strobus is effective at increasing tree basal area on site, it may hinder establishment of herbaceous vegetation as the canopy becomes more closed (Ashby 1964, Schuster \& Hutnik 1987, Holl 2002). Additionally, pine plantations have lower wildlife value than hardwood stands (Leedy 1981). 
However, establishment of tree species in general is advised as some vegetative species may be unable to colonize without presence of a canopy (Holl \& Cairns 1994).

Holl and Cairns (1994) found the number of species increased with age since reclamation. Other authors found a large number of native species had colonized reclaimed surface mines after 10-15 years (Thompson et al. 1984, Skousen et al. 1994, Thompson et al. 1996, Rodrigue 2001). Often reclaimed sites are dominated by generalist species such as Acer rubrum (Holl 2002) and species dependent on insect activity or gravity for seed dispersal are not present (Holl 2002, McLachlan \& Bazely 2001). Holl (2002) estimates a time period of over 35 years before reclaimed sites host a vegetative community fully comparable to reference sites.

Suggestions for the improvement of vegetation establishment include keeping reclaimed mine sites within 50 meters from intact forest to provide a seed source (Holl 2002), additional research on naturalized ground covers such as wildflowers that would not impede vegetation succession (Holl 2002), planting a variety of tree species for a diverse canopy (Holl 2002), improvement of within-site environmental conditions (Holl \& Cairns 1994), and movement of soil from imminently mined locations to reclaimed sites (Garrison 1992).

Parameters that cannot be reclaimed on-site are often mitigated for off-site usually through habitat enhancement structures and channel reconfiguration techniques that seek to improve water quality, in stream habitat, and bank stabilization (Bernhardt et al. 2007). 


\subsection{Reclamation Challenges}

Despite BMPs, challenges in mining reclamation still exist. The production of AMD and the export of sediments are largely avoided but high TDS and conductivity concentrations remain and are exported downstream (Pond et al. 2008, Minter 2009, Merriam 2009). Additionally, the ecological functions of reclaimed mine sites are largely unmeasured and the effectiveness of off-site mitigation efforts to recapture discrepancies in function may be questioned.

\subsection{Remaining Questions}

Numerous important questions remain. To what extent do reclaimed headwater watersheds function in comparison to native headwater watersheds? Which ecosystem structures and functions may be completely lost despite reclamation? Which functions are significantly reduced? Which functions are comparable? Which functions are increased? Which functions may improve with time? Do techniques exist to improve functional reclamation? Which remaining functional deficits need to be addressed through off-site mitigation?

\subsection{Objectives}

The overriding objective of this research project was to quantify and contrast ecological function of reference aquatic features to post-reclamation aquatic features that develop on reclaimed surface mines in southern West Virginia. The long-range goal is to maximize the functional value of on-site aquatic features and the recovery of lost 
headwater functions throughout the Appalachian region. In this study, we addressed the following specific objectives:

\section{Objectives:}

1. quantify the functional value of reference headwater streams and of postreclamation aquatic features;

2. determine whether ecological functions are adequately replaced after mining and reclamation; and

3. develop recommendations for mining reclamation and direction for future studies.

\subsection{Methods}

\subsection{Study Area}

Perimeter channel sites consisted of five boulder-filled, sediment control structures on the perimeter of reclaimed surface mine lands in the coal-rich region southwest of Charleston, WV (Fig. 1). Within the region, typical post-reclamation surface mine structures are composed of a re-contoured and re-vegetated “on-bench” site located adjacent to, and at greater elevation than, adjacent valley fills associated with the site. The chosen sites varied in drainage area and age since reclamation but all were designed so that any overland flow from reclaimed mine lands drained towards the perimeter of the site and into the perimeter channels. All sites drained towards an "onbench" outflow notch in the berm that surrounded the reclaimed surface mine perimeter. Figure 2 illustrates a typical reclaimed mine perimeter channel series in comparison to a 
typical undisturbed headwater system. Study reaches within the sites began one retention

cell above the channel series off-site outflow notch and continued upstream a length of 10 times the mean channel width. If the outflow notch was located at the confluence of two perimeter channels, the wetter channel series was chosen.

These features were constructed primarily for the purpose of slowing and retaining water to allow the settling-out of suspended sediments and some ions from the water column before discharge of water off-site. Information on estimated age since reclamation was included in the study, however, no information on the site's history of maintenance dredging and re-contouring since reclamation was obtained. Therefore, overall age since reclamation may not represent a continuous successional trajectory. Additionally, perimeter channel sites were not intentionally designed to encourage ecological function. Any vegetation growth or colonization by macroinvertebrates or amphibians was not an intended use of the structure.

Reference sites consisted of five intermittent streams within the region that were of the best sites available within a reasonable proximity to perimeter channel sites. These were relatively unaffected by disturbance and accessible by road. Sites were selected using winter and spring 2008 water chemistry measurements as well as topographic maps and general knowledge of the area. Reach length was measured at 10 times the mean stream width with a minimum length of $50 \mathrm{~m}$. A list of site names, watersheds, and drainage areas are given in Table 1. 


\subsection{Physical Habitat}

\section{Habitat Quality}

Habitat analysis was performed using classification systems such as Virginia Unified Stream Method (USACOE 2007), West Virginia Functional Channel Unit Assessment (USACOE \& VADEQ 2007), Wildland Hydrology’s Bank Erosion Hazard Index (Rosgen 2001), Environmental Protection Agency Rapid Bioassessment Protocol (Barbour et al. 1999), and Ohio Rapid Assessment Method (Mack 2001). These systems use simple measurements and visual assessments to assign sites numerical scores to each site. Categorical habitat qualifiers (e.g. excellent, good, poor) were derived from calculated scores.

\section{$\underline{\text { Vegetation }}$}

Vegetation was sampled according to protocols adapted from Batzer et al. (2004), Balcombe (2005, b), and Rentch et al. (2008). Thirty meter long transects were run across the site perpendicular to the length of the stream or perimeter channel. A pin flag was used every $2 \mathrm{~m}$ along the transect to record any intercepting vegetation. Additionally, fifteen $1 \times 1 \mathrm{~m}$ plots were placed along each transect. Within each plot, percent cover was estimated using 14 categories (bare ground, cattail, exposed substrate, fern, forb, grass, moss, open water, rush, sedge, shrub, submerged vegetation, tree, and vine). All course woody debris within the plot was tallied and recorded. Canopy cover was estimated using a spherical densitometer. Diameter at breast height (dbh) and species was recorded for any trees $>2.5 \mathrm{~cm}$ dbh and within $10 \mathrm{~m}$ of the transect. Any additional species not captured in survey measurements were noted. 


\subsection{Water Chemistry, Temperature, and Discharge}

\section{Water Chemistry}

Sites were visited seasonally from February 2008 to May 2009. A list of sample dates is given in Table 2. Instantaneous water chemistry measurements were taken at each visit with a Yellow Springs Instrument (YSI) 650 multi-parameter probe equipped with a 600XL sonde. The YSI was calibrated before every site visit. The probe measured temperature, $\mathrm{pH}$, conductivity, and dissolved oxygen.

Seasonal water samples were taken to analyze dissolved water chemistry including metals and nutrients following protocols by Merovich et al. (2007). Grab samples were taken by completely filling a sampling bottle under the water's surface. Filtered samples were taken using a vacuum pump and mixed ester cellulose membrane $0.45 \mu \mathrm{m}$ filter. Nitric acid $\left(\mathrm{HNO}_{3}\right)$ was added to keep all solutes in solution. Analysis was performed by the National Research Center for Coal and Energy at West Virginia University, Morgantown, WV. Alkalinity was measured in $\mathrm{CaCO}_{3}$ equivalents and presented as mg/L. If samples were measured below the method detection limit (MDL), one half of the MDL was used in analysis. Samples measuring below MDL are presented as "MDL" in figures. Mean seasonal data was calculated using three seasons only (spring, summer, and winter) because of the absence of water during autumn sampling.

Specific limits for parameters were taken from West Virginia guidelines for warm water fisheries and comply with EPA regulations. For limits dependent on hardness, a hardness of 0-50 mg/L was used to determine limits. Total dissolved solids (TDS) was calculated by summing seasonal measurements for dissolved ions. 


\section{Water Temperature}

Hourly temperature readings were taken from June 2008 until June 2009 using HOBO U22 Water Temp Pro v2 loggers (Onset Computer Corporation, Pocasset, MA). No temperature readings were recovered from P_WO before the temperature logger was buried by bulldozer activity. Loggers for R_WO and R_MW ceased logging prior to June 2009 and resulted in incomplete data. Data from periods when loggers were inundated were used for analysis.

\section{Discharge}

Discharge was calculated from width, depth, and flow measurements taken at each site visit. Flow was measured using a Flow Mate 2000 flow meter. Measurements were summarized by season for analysis.

\subsection{Biotic Components}

\section{$\underline{\text { Amphibians }}$}

Amphibians were sampled seasonally in early and late spring and early and late summer (March, May, June, and July) of 2008. This series of sampling sought to maximize the diversity captured for each site as well as sample during all potential breeding seasons for probable amphibian species. Adult assemblages were estimated using Visual Encounter Surveys (VES) performed in accordance with protocols set by Crump and Scott (1994). Larval Surveys were adapted from methods by Shaffer et al. (1994). The surveys were comprised of consistent meter-long sweeps with a D-frame net in open-water and consistent meter by half-meter area searches in stream channels. Each search was done at 10 random locations over the length of the site. 


\section{Macroinvertebrates}

Macroinvertebrates were sampled in spring and fall 2008. Within lotic systems, macroinvertebrates were sampled using protocols established by Merovich and Petty (2007), which are slight modifications of procedures described by the West Virginia Department of Environmental Protection's Watershed Assessment Program and the EPA’s Rapid Bioassessment Protocols for wadeable streams (WVDEP 1996, Barbour et al. 1999). Within each reach, four representative riffles were sampled using a $250 \mu \mathrm{m}$ Dframe kicknet. Within lentic systems, a D-frame net was used to take jab samples at 10 random locations along the reach. Lentic samples were taken according to protocols set by King and Richardson (2002) and Balcombe et al. (2005a). Samples were preserved with 70\% ethanol and identified to the lowest possible taxonomic level. Fall 2008 samples were obtained in perimeter sites only due to low water in reference sites. Consequently, we analyzed data from spring samples only.

Stream condition was derived from macroinvertebrate samples using a modified West Virginia Stream Condition Index (WVSCI) score developed by Merriam (2009) from original Gerritsen et al. (2000) protocols. This index uses family-level community metrics to categorize stream condition as either poor, marginal, good, or excellent.

\subsection{Organic Matter Processing}

\section{Organic Matter Retention}

OM transport was measured using methods adapted by Minter (2009) from protocols established by Speaker et al. (1984), Webster et al. (1994), Raikow et al. (1995), and Lamberti (1996). Cumulative retention was measured using artificial sticks, 
consisting of painted dowel rods, and instantaneous retention was measured using artificial leaves, consisting of rectangles of blue construction paper. Fifty dowel rods were placed in a riffle at the upstream end of the reach. They remained on-site and the cumulative distance they traveled was measured at four intervals over 195 days (on the day of release and then after approximately 1 month, 2 months, and 6 months). Twenty artificial leaves were also placed in a riffle at the upstream end of each reach seasonally. They were allowed to travel downstream for 30 minutes then their distances traveled were recorded.

Retention rate was calculated for each site using the cumulative distances traveled by artificial sticks. The equation $T_{d}=T_{0} e^{-k d}$, where $T_{d}$ is the percentage of released sticks remaining in transport at distance $\mathrm{d}, \mathrm{T}_{\mathrm{o}}$ is the original number of sticks released, and $\mathrm{k}$ is the instantaneous rate of retention, was used to calculate retention rate (Speaker et al. 1984, Raikow et al. 1995, Minter 2009).

\section{Dissolved Organic Carbon}

Seasonal water samples were taken from each site. Samples were filtered with a $0.45 \mu \mathrm{m}$ filter and treated with nitric acid $\left(\mathrm{HNO}_{3}\right)$. Samples were analyzed using a Sievers 5310c laboratory TOC Analyzer to estimate total dissolved carbon and dissolved organic carbon concentrations.

\section{Organic Matter Decomposition}

Leaf litter packs were constructed from plastic mesh bags (10 mm mesh size). This allowed the bag to hold material in one location without restricting access to the material by invertebrates or breakdown of the material by water flow. Bags were filled 
with $10 \mathrm{~g}$ of Quercus palustris (pin oak) leaves collected after abscission and air-dried for approximately two weeks to a constant mass. Bags were grouped in sets of six and anchored in riffles throughout the reach length. An additional set of litter bags was taken to the site and returned to the lab to calculate for handling loss. Litter bags were randomly sampled after $45,75,90,120,195$, and 325 days on site. Bags were returned to the lab on ice and rinsed in a $250 \mu \mathrm{m}$ sieve. Macroinvertebrates present in litter bags were collected, preserved, and identified. Leaf litter was placed in brown paper bags and dried for approximately 48-72 hours to a constant mass. After drying, leaf litter was reduced to particulate size and subsampled. A subsample of $250 \mu \mathrm{g}$ was placed into pans and incinerated to determine the ash free dry mass. Methods were adapted from protocols by Benfield (1996). Decomposition rates (-k) were determined from the linear regression of the plot of the number of days of exposure versus the log-transformed percent ash-free dry mass (\% AFDM). AFDM was calculated using the following formula from Benfield (1996):

$\left(\right.$ Equation 1) \% Organic Matter $=\left(\mathrm{DM}_{\text {sample }}-\mathrm{AM}_{\text {sample }}\right) / \mathrm{DM}_{\text {sample }} \mathrm{x} 100$ $\mathrm{AFDM}=\mathrm{DM} \times \mathrm{\%}$ Organic Matter $\%$ AFDM remaining $=100-(($ initial - final $) /$ initial $x$ 100 $)$ Where: $\mathrm{DM}=$ dry mass; $\mathrm{AM}=$ ash mass The slope of the line after regression provided the rate of decomposition $(\mathrm{k})$. Expected decomposition rates for Quercus range from $\mathrm{k}=(0.0014)$ to $\mathrm{k}=(0.021)$ (Beiser et al. 1991, D’Angelo \& Webster 1992). 


\section{Processing Power}

Processing power was defined as the ability of a site to retain and process organic matter locally. Processing power of each site was calculated by multiplying the instantaneous rate of decomposition by the instantaneous rate of retention.

\subsection{Site Comparison}

Because pre-mining reference sites were intermittent streams and postreclamation perimeter channels sites resembled wetlands, measured parameters differed in terms of how directly comparable they were. Some parameters such as water chemistry and decomposition rate are directly comparable between site types (Fig. 3). However, some parameters such as gradient and vegetation community may not be directly comparable between site types.

\subsection{Ecological Units}

Ecological units (EUs) (Petty \& Thorne 2005, Merovich \& Petty 2007) were calculated for parameters selected as important metrics for both perimeter and reference site types. They were calculated by dividing the perimeter mean by the reference mean for each parameter. EUs with values greater than one represent ecosystem parameters with higher values on the perimeter channel sites than in reference catchments. EUs with values less than one represent ecosystem parameters with higher values in reference streams than in perimeter channels.

\subsection{Statistical Analysis}

Data were transformed using $\log _{10}$, arcsine, and square roots of measured values before analysis in order to approximate normality within the data. Correlation analysis 
was run on all parameters to quantify relationships between ecosystem parameters and both conductivity and time (with respect to perimeter channels only). T-tests were used to test for statistical differences in ecosystem parameters between site types (perimeter and reference). Repeated measures ANOVAs were used to test for seasonal variation in ecosystem parameters between perimeter and reference sites. ANCOVAs were used to test for interactive effects of site type and specific conductivity on ecosystem parameters. Relation among macroinvertebrate and amphibian communities and environmental variables were examined using non-metric multidimensional scaling (NMDS). NMDS is a statistical ordination, developed by Clarke (1993). This nonparametric analysis involves iterative solutions that allow species composition data to be plotted in ordination space with reduced stress (McCune \& Grace 2002). This analysis enables the determination of community similarities as well as the influence of environmental variables on community composition. Additionally, Spearman rank correlations were run between NMDS scores and community metrics (Merovich \& Petty 2007, McClurg et al. 2007, Merriam 2009).

All statistical analyses were conducted using the program R Project for Statistical computing version 2.8.1 (R Development Core Team 2008) unless otherwise stated. NMDS analysis was run using the package vegan (Oksanen et al. 2008). All values were considered significant at an alpha level of 0.05 unless otherwise indicated. 
4.0 Results

\subsection{Habitat Quality}

Habitat quality measures were consistently higher in reference channels than in perimeter channels regardless of the assessment protocol. EPA rapid bioassement protocol (RBP) scores averaged 78 for perimeter channels and 150 for reference sites (Table 3). Mean scores for the Virginia unified stream method (VA USM) were 4 for perimeter channels and 6 for reference sites. West Virginia functional channel unit (WV FCU) assessment scores averaged 3 for perimeter channels and 9 for reference sites. In the case of Wildland Hydrology's bank erosion hazard index (BEHI), the higher the score, the more prone a site is to erosion. BEHI scores averaged 23 for perimeter channels and 39 for reference sites. All habitat assessments were significantly higher in reference sites than in perimeter channels (Table 4).

The Ohio Rapid Assessment Method (ORAM) version 5.0 was designed to rank overall wetland quality and to categorize natural wetlands based on amount of disturbance (Mack 2001). The higher the score, the less disturbed the wetland. Perimeter channels averaged an ORAM score of 35 and reference sites averaged 61. ORAM scores were significantly higher in perimeter channels than in reference sites (Table 4).

\subsection{Vegetation}

Perimeter channel sites were dominated by forb (22\%), grass (22\%), cattail (21\%), and open water (13\%) (Table 5). Reference sites were dominated by bare ground (29\%), forb (22\%), trees (16\%), and fern (11\%). Mean percent canopy cover was 4\% for perimeter channels and 91\% for reference sites (Table 6). Perimeter channels had, on 
average $0.3 \pm 0.6$ trees and $0.1 \pm 0.2$ tree species per $\mathrm{km}^{2}$ survey versus an average of 9.2 \pm 5 trees and $2.5 \pm 0.7$ species per $\mathrm{km}^{2}$ in reference sites. All vegetation measures were significantly different between site types except for percent open water and forb.

\subsection{Water Chemistry}

Parameters that Were Similar Between Site Types

\section{$\mathrm{pH}$}

The majority of sites had mean seasonal $\mathrm{pH}$ measurements that fell within the range of 6.0-8.0 (Fig. 4). Mean summer $\mathrm{pH}$ was significantly higher in perimeter channels (7.39) than in reference channels (6.74) (Table 4). Greater pH variation occurred among reference sites than among perimeter channel sites. One reference site, R_WO, had consistently low pH ranging from a low of 4.35 in summer to a high of 5.82 in autumn. When excluding R_WO from the analyses, $\mathrm{pH}$ was similar between reference sites (7.15 excluding R_WO) and perimeter channel sites. No significant difference in mean $\mathrm{pH}$ was observed between reference and perimeter channel sites (Table 4).

\section{Dissolved Oxygen}

Dissolved oxygen (DO) levels below $5.0 \mathrm{mg} / \mathrm{L}$ stress aquatic life. Statistically significant trends were shown for DO in regards to season (Table 4). The seasonal mean for all sites was above the $5.0 \mathrm{mg} / \mathrm{L}$ level except R_ME which had a summer mean of 4.5 mg/L (Fig. 5). Perimeter channel sites averaged $8.7 \mathrm{mg} / \mathrm{L}$ and reference sites averaged $9.9 \mathrm{mg} / \mathrm{L}$ for the study duration. No significant difference in dissolved oxygen concentrations was observed between reference and perimeter channel sites (Table 4). 
Dissolved oxygen did, however, show statistically significant trends with regards to seasonal concentration (Table 7).

Manganese

West Virginia water quality criteria in conformance with USEPA regulations limits manganese within warm-water fisheries (WWF) to a level of $1 \mathrm{mg} / \mathrm{L}$. Most perimeter channels averaged above this limit and reference sites averaged below this level (Fig. 6). Reference site R_WO’s spring, summer, and winter measurements were 1.87, 1.90, and $1.10 \mathrm{mg} / \mathrm{L}$ respectively. Mean seasonal measurement for perimeter channels was $0.3 \mathrm{mg} / \mathrm{L}$. Mean seasonal measurement for reference sites was $0.1 \mathrm{mg} / \mathrm{L}$ excluding measurements from R_WO (0.4 mg/L for all reference sites). No significant difference in manganese concentrations was observed between reference and perimeter channel sites (Table 4). Seasonal water chemistry measurements for each site can be found in Appendix A.

Iron

The WWF limit for iron is $1.5 \mathrm{mg} / \mathrm{L}$ (Fig. 7). All sites were below this level. Mean seasonal measurements were $0.10 \mathrm{mg} / \mathrm{L}$ for perimeter channels and $0.06 \mathrm{mg} / \mathrm{L}$ for reference sites. Mean iron concentrations were not significantly different between site types (Table 4).

Zinc

The WWF level for zinc is $0.04 \mathrm{mg} / \mathrm{L}$. Most site measurements were below these levels (Fig. 8). Autumn measures for P_BH $(0.115 \mathrm{mg} / \mathrm{L})$ and P_WO $(0.141 \mathrm{mg} / \mathrm{L})$ exceeded recommended levels. Seasonal measurements for perimeter channels averaged 
$0.020 \mathrm{mg} / \mathrm{L}$ and $0.042 \mathrm{mg} / \mathrm{L}$ for reference sites. No significant difference in zinc concentrations was observed between reference and perimeter channel sites (Table 4).

Selenium

WWF level for selenium is $0.005 \mathrm{mg} / \mathrm{L}$. However, method detection limits (MDL) of the water sample analysis technique were $0.045 \mathrm{mg} / \mathrm{L}$. All sites were at this detection level except for autumn measurements for P_ST $(0.173 \mathrm{mg} / \mathrm{L})$ and P_WO (0.148 mg/L) (Fig. 9). No significant difference in selenium concentrations was observed between reference and perimeter channel sites (Table 4).

Nitrite

The WWF limit for nitrite is $5 \mathrm{mg} / \mathrm{L}$ of nitrite. Most seasonal measurements for nitrite were below $0.1 \mathrm{mg} / \mathrm{L}$ (Fig. 10). Summer measurement for P_WO was $0.40 \mathrm{mg} / \mathrm{L}$. Summer measurement for R_HC was $46.23 \mathrm{mg} / \mathrm{L}$ after disturbance. Mean seasonal measurements were $0.04 \mathrm{mg} / \mathrm{L}$ for perimeter channels and $0.02 \mathrm{mg} / \mathrm{L}$ for reference sites, excluding R_HC measurements (reference site mean was $3.10 \mathrm{mg} / \mathrm{L}$ including all sites). No significant difference in nitrite concentrations was observed between reference and perimeter channel sites (Table 4).

Nitrate

The WWF limit for nitrate is $90 \mathrm{mg} / \mathrm{L}$. The majority of sites were below $20 \mathrm{mg} / \mathrm{L}$ (Fig. 11). Summer and autumn measurements for P_WO were $143.8 \mathrm{mg} / \mathrm{L}$ and 79.3 $\mathrm{mg} / \mathrm{L}$ respectively. Mean seasonal measurements were $0.8 \mathrm{mg} / \mathrm{L}$ for reference sites and $0.6 \mathrm{mg} / \mathrm{L}$ for perimeter channels excluding P_WO measurements (perimeter site mean 
was 11.0 including all sites). No significant difference in nitrate concentrations was observed between reference and perimeter channel sites (Table 4).

Total Phosphorus

In 1986, the EPA recommended a phosphorus level of $0.1 \mathrm{mg} / \mathrm{L}$ for rivers not emptying into reservoirs. All sites were below this level except P_WO which measured $0.68 \mathrm{mg} / \mathrm{L}$ (winter) after disturbance (Fig. 12). Mean seasonal measurements were 0.07 mg/L (0.04 mg/L excluding P_WO) for perimeter channels and $0.05 \mathrm{mg} / \mathrm{L}$ for reference sites. No significant difference in total phosphorus concentrations was observed between reference and perimeter channel sites (Table 4).

Barium

All sites measured below $1.0 \mathrm{mg} / \mathrm{L}$ of barium for all seasons. Generally sites measured below $0.2 \mathrm{mg} / \mathrm{L}$ except R_HC which measured $0.887 \mathrm{mg} / \mathrm{L}$ in summer (Fig. 13). Mean seasonal measurements were $0.016 \mathrm{mg} / \mathrm{L}$ for perimeter channels and 0.093 $\mathrm{mg} / \mathrm{L}$ for reference sites. No significant difference in barium concentrations was observed between reference and perimeter channel sites (Table 4).

Ammonia

The WWF limit for ammonia is $0.05 \mathrm{mg} / \mathrm{L}$. All sites were below this level except for P_ST which measured $0.087 \mathrm{mg} / \mathrm{L}$ (autumn) and R_HC which measured 0.056 (summer) after disturbance (Fig. 14). Mean seasonal measurements were $0.007 \mathrm{mg} / \mathrm{L}$ for perimeter channels and $0.013 \mathrm{mg} / \mathrm{L}$ for reference sites. No significant difference in ammonia concentrations was observed between reference and perimeter channel sites (Table 4). 


\section{Cobalt}

There are no recommended limits for cobalt. MDL for cobalt during analysis was $0.015 \mathrm{mg} / \mathrm{L}$. Measurements for all sites were at the MDL except for P_BH $(0.021 \mathrm{mg} / \mathrm{L}$; autumn), P_ST (0.054 mg/L; autumn), P_WO (0.021 mg/L; summer), and P_SU (0.018 mg/L; summer) (Fig. 15). Mean seasonal measurements were $0.011 \mathrm{mg} / \mathrm{L}$ for perimeter channels and $0.009 \mathrm{mg} / \mathrm{L}$ for reference sites. No significant difference in cobalt concentrations was observed between reference and perimeter channel sites (Table 4).

\section{Copper}

The WWF limit for copper is $0.006 \mathrm{mg} / \mathrm{L}$. MDL during analysis for copper was $0.015 \mathrm{mg} / \mathrm{L}$. All sites were at MDL except P_BH which measured $0.027 \mathrm{mg} / \mathrm{L}$ (autumn) and P_ST which measured $0.061 \mathrm{mg} / \mathrm{L}$ (autumn) (Fig. 16). Mean seasonal measurements for analysis were $0.008 \mathrm{mg} / \mathrm{L}$ for perimeter channels and $0.008 \mathrm{mg} / \mathrm{L}$ for reference sites. No significant difference in copper concentrations was observed between reference and perimeter channel sites (Table 4).

\section{Cadmium}

The WWF limit for cadmium is $0.007 \mathrm{mg} / \mathrm{L}$. However, MDL for cadmium was $0.014 \mathrm{mg} / \mathrm{L}$. All sites measured at the MDL except P_BH which measured $0.023 \mathrm{mg} / \mathrm{L}$ (autumn) and P_ST which measured 0.057 mg/L (autumn) (Fig. 17). Mean seasonal measurements for analysis were $0.007 \mathrm{mg} / \mathrm{L}$ for perimeter channels and $0.008 \mathrm{mg} / \mathrm{L}$ for reference sites. No significant difference in cadmium concentrations was observed between reference and perimeter channel sites (Table 4). 


\section{$\underline{\text { Parameters that Differed Between Site Types }}$}

Acidity

Perimeter channels averaged 0 mg/L acidity for all seasons (Fig. 18). Reference sites averaged $13 \mathrm{mg} / \mathrm{L}$ over the duration of the study. Mean acidity was significantly lower in perimeter channels than in reference sites (Table 4).

\section{Alkalinity}

Waters with alkalinity measures above $20 \mathrm{mg} / \mathrm{L}$ are considered to have good buffering capacity. Alkalinity averaged $138 \mathrm{mg} / \mathrm{L}$ for perimeter channels and $5 \mathrm{mg} / \mathrm{L}$ for reference sites (Fig. 19). Mean alkalinity concentrations were significantly higher in perimeter channels than reference sites (Table 4).

\section{Calcium and Magnesium}

Mean seasonal measurements of calcium were significantly higher in perimeter channels (163 mg/L) than in reference sites (21 mg/L) (Fig. 20, Table 4). Streams with magnesium sources usually have levels of 5-50 mg/L. Mean seasonal measurements of magnesium were also significantly higher in perimeter channels $(154 \mathrm{mg} / \mathrm{L})$ than in reference sites (9 mg/L) (Fig. 21, Table 4).

Sulfate

Perimeter channels measured above $250 \mathrm{mg} / \mathrm{L}$ and reference streams measured below this level (Fig. 22). Mean seasonal measurements for perimeter channels were 1008 mg/L. Mean seasonal measurements for reference sites were 32 mg/L. Mean sulfate levels were significantly different between site types. Mean sulfate concentrations were significantly higher in perimeter channels than reference sites (Table 4). 


\section{Chromium}

The WWF limit for chromium is $0.01 \mathrm{mg} / \mathrm{L}$. However, MDL for chromium was

$0.012 \mathrm{mg} / \mathrm{L}$. All sites measured below $0.03 \mathrm{mg} / \mathrm{L}$ except P_ST which measured 0.066 mg/L (autumn) (Fig. 23). The mean seasonal measurements were $0.006 \mathrm{mg} / \mathrm{L}$ for perimeter channels and $0.009 \mathrm{mg} / \mathrm{L}$ for reference sites. Chromium concentrations were significantly higher in perimeter channel sites than in reference sites (Table 4).

Specific Conductivity and TDS

The U. S. Environmental Protection Agency (EPA) recommends a specific conductivity level of 150- $500 \mu \mathrm{S} / \mathrm{cm}$ for aquatic health. Mean specific conductivity exceeded the recommended level of $500 \mu \mathrm{S} / \mathrm{cm}$ at all perimeter channels for all seasons during the study period (Fig. 24). The mean measured specific conductivity for perimeter channels was $2197 \mu \mathrm{S} / \mathrm{cm}$. Reference sites averaged below $500 \mu \mathrm{S} / \mathrm{cm}$ with the exception of R_HC which measured 2362 (spring) and 2632 (summer) due to an upstream disturbance. Mean specific conductivity for reference sites, excluding R_HC, was $141 \mu \mathrm{S} / \mathrm{cm}$ (overall mean was $461 \mu \mathrm{S} / \mathrm{cm}$ for reference sites). Mean conductivity levels were significantly higher in perimeter channels than reference sites (Table 4). Specific conductivity was positively correlated with mean alkalinity, discharge, calcium, iron, magnesium, sulfate, summer $\mathrm{pH}$, TDS, percent macroinvertebrate predator, and percent open water (Table 4). Conductivity was negatively correlated with percent Ephemeroptera, Plecoptera, and Trichoptera (EPT), and EPT richness (Table 4).

Mean TDS was also significantly higher in perimeter channels than in reference sites (Table 4). Mean TDS measures were $1501 \mathrm{mg} / \mathrm{L}$ in perimeter channels and 103 
$\mathrm{mg} / \mathrm{L}$ in reference sites. TDS was composed primarily of bicarbonate, calcium, magnesium, sulfate, chloride, and sodium (Fig. 25). The mean percent of TDS composed of sulfate in perimeter channels was $66 \%$ and $43 \%$ in reference sites. TDS also showed significant trends in relation to seasonal concentrations (Table 7).

$\underline{\text { Parameters with Unusual Values }}$

Aluminum

The WWF limit for aluminum is $0.75 \mathrm{mg} / \mathrm{L}$. Seasonal measurements for all sites were below these levels except for R_WO (Fig. 26). R_WO measured 3.0 mg/L (spring), $3.1 \mathrm{mg} / \mathrm{L}$ (summer), and $1.3 \mathrm{mg} / \mathrm{L}$ (winter). Mean seasonal measurements were $0.1 \mathrm{mg} / \mathrm{L}$ for perimeter channels and $0.5 \mathrm{mg} / \mathrm{L}$ for reference sites. No significant difference in aluminum concentrations was observed between reference and perimeter channel sites (Table 4).

Nickel

The WWF limit for nickel is $0.088 \mathrm{mg} / \mathrm{L}$. All sites measured below this level for all seasons except P_WO which measured $0.132 \mathrm{mg} / \mathrm{L}$ (summer) and $0.144 \mathrm{mg} / \mathrm{L}$ (winter) (Fig. 27). Mean seasonal measurements for perimeter channels were $0.034 \mathrm{mg} / \mathrm{L}$ (0.016 mg/L excluding P_WO) and $0.024 \mathrm{mg} / \mathrm{L}$ for reference sites. No significant difference in nickel concentrations was observed between reference and perimeter channel sites (Table 4).

Chloride

The WWF limit for chloride is $250 \mathrm{mg} / \mathrm{L}$. Most seasonal chloride measures were below this limit (Fig. 28). Seasonal measures for P_BH were $43.1 \mathrm{mg} / \mathrm{L}$ (spring), 90.6 
(summer), $111.2 \mathrm{mg} / \mathrm{L}$ (autumn), and $24.3 \mathrm{mg} / \mathrm{L}$ (winter). Seasonal measures for R_HC after disturbance were $1070.7 \mathrm{mg} / \mathrm{L}$ (summer) and $102.4 \mathrm{mg} / \mathrm{L}$ (winter). Mean seasonal measurements for perimeter channels were $13.8 \mathrm{mg} / \mathrm{L}$ (4.5 mg/L excluding P_BH) and 11.4 mg/L (1.17 mg/L excluding R_HC) for reference sites. No significant difference in chloride concentrations was observed between reference and perimeter channel sites (Table 4).

\section{Sodium}

All sites measured below 20 mg/L except P_BH, P_ST, and R_HC (Fig. 29). P_BH measured $40.3 \mathrm{mg} / \mathrm{L}$ (spring), $44.3 \mathrm{mg} / \mathrm{L}$ (summer), $61.4 \mathrm{mg} / \mathrm{L}$ (autumn), and 28.4 mg/L (winter). P_ST measured 20.9 mg/L (spring). R_HC measured 293.2 mg/L (summer) and $44.0 \mathrm{mg} / \mathrm{L}$ (winter) after disturbance. Mean seasonal measurements were $7.8 \mathrm{mg} / \mathrm{L}$ for perimeter channels, excluding P_BH (13.2 mg/L including all sites), and 1.6 mg/L for reference sites, excluding R_HC (23.7 mg/L including all sites). No significant difference in sodium concentrations was observed between reference and perimeter channel sites (Table 4).

\subsection{Temperature}

Continuous temperature loggers providing a year's worth of data showed perimeter channels to have a similar temperature range to reference sites $\left(10.44 \pm 0.56{ }^{\circ} \mathrm{C}\right.$ vs $9.59 \pm 1.67^{\circ} \mathrm{C}$ respectively) (Table $4 \&$ Table 8 ). There was no overall trend in temperature between site types (Fig. 30, 31 \& 32). Statistically significant trends were shown for temperature in regards to season (Table 7). Seasonal temperature measurements are summarized in Appendix B. 


\subsection{Discharge}

Statistically significant trends were shown for discharge in regards to season (Table 7). Seasonal discharge averaged higher in perimeter channels than in reference sites $\left(0.00897 \mathrm{~m}^{3} / \mathrm{s}\right.$ vs. $0.00233 \mathrm{~m}^{3} / \mathrm{s}$ respectively) (Fig. 33). Mean spring discharge was significantly higher in perimeter channel sites than reference sites (Table 4). Flows were highest for all sites in winter. All reference streams except R_WO had little to no flow from late summer through early autumn. Perimeter channel sites showed more variation between their seasonal averages than reference sites. Mean seasonal standard deviation was $\pm 0.0089 \mathrm{~m}^{3} / \mathrm{s}$ for perimeter channels and $\pm 0.0021 \mathrm{~m}^{3} / \mathrm{s}$ for reference sites.

\subsection{Amphibians}

Perimeter channels contained, on average, more larval amphibians than reference sites (avg 19 vs 8 individuals) and supported about the same number of species (avg 2 species) (Table 9). Mean larval biomass also averaged higher in perimeter channels (1.33

$\left.\mathrm{g} / \mathrm{m}^{2}\right)$ than reference sites $\left(0.05 \mathrm{~g} / 100 \mathrm{~m}^{2}\right)$ (Table 10$)$. Perimeter channels contained, on average, less adult amphibians than reference sites (avg 5 vs 28 individuals) but supported a similar number of adult species (avg 2 vs 3 species). When the effects of conductivity were removed, larval amphibian richness, total number of larval amphibians, and the percent of lotic-utilizing amphibians was statistically different between site types with perimeter channels supporting more larva and reference sites supporting more lotic-utilizing species (Table 11). Overall density was not statistically different between perimeter channels and reference sites (Table 4, Table 12, Fig. 34). Amphibian survey data can be found in Appendices C-E. 
Perimeter channels supported primarily terrestrial and aquatic frogs that use lentic systems. Reference sites supported primarily aquatic salamanders that use lotic systems (Table $9 \&$ Table 13). The species of both site types were able to use forest habitats but perimeter channels supported a statistically significant higher percentage of grasslandutilizing species (Table 4). Additionally, perimeter channels supported a significantly lower percentage of lotic-utilizing species and a significantly higher percentage of lenticutilizing species (Table 4). The percent of lentic species was positively correlated with conductivity and percent lotic species was negatively correlated with conductivity (Table 4).

NMDS ordination analysis revealed clustering by site types. Amphibian community structure was primarily influenced by vegetation and water chemistry parameters including percent open water, grass, cattail, bare ground, canopy cover, fern, and number of species per $\mathrm{km}^{2}$ (Fig. 35). Increasing percent open water, grass and cattail indicated a perimeter- type amphibian community while increasing percent bare ground, canopy cover, fern, and species per $\mathrm{km}^{2}$ indicated a reference- type community structure. Statistically significant water chemistry influences included mean specific conductivity, sulfate, magnesium, mean total dissolved solids, calcium, alkalinity, and iron (Fig. 36). Increasing measures of all these parameters indicated a perimeter- type community composition. Additionally, ANCOVA analysis revealed significant interactions between site type and site conductivity for amphibian species richness, larval richness, total number of amphibians, mean number of amphibians, number of larval amphibians, mean density, and percent forest-utilizing amphibians (Table 11, Fig. 38-42). 


\subsection{Macroinvertebrates}

Perimeter channels and reference sites had similar macroinvertebrate family richness and biomass. Perimeter channels had an average of 8 families and reference sites had an average of 7 families (Table 14). Perimeter channels had an average biomass of $31.76 \mathrm{~g} / \mathrm{m}^{2}$ and reference sites had an average of $34.47 \mathrm{~g} / \mathrm{m}^{2}$. Perimeter channels had a higher percentage of tolerant species (70\% vs $42 \%$ ) and chironomids (58\% vs $32 \%$ ) than reference sites (not statistically different, Table 4). Perimeter channels had a significantly lower percentage of Ephemeroptera, Plecoptera, and Trichoptera (EPT) (5\%) than reference sites (48\%) and a significantly lower EPT richness (1 vs 4) (Table 4). These parameters, along with WVSCI score, were significantly different with regards to mean conductivity (Table 11). Additional ANCOVA analysis revealed significant interactions between site type and site conductivity for percent EPT, EPT richness, and total richness (Table 11, Fig. 43-46).

Macroinvertebrate data were used to rank the quality of site habitat using the West Virginia Stream Condition Index (WVSCI). WVSCI ranks overall stream quality based on measures of the benthic invertebrate community. The higher the score, the better the stream condition. Perimeter channels had an average WVSCI score of 48 (Poor) and reference sites had an average score of 68 (Marginal). Excluding R_WO, the mean score for reference sites was 74 (Good). Perimeter channels ranged from poor to marginal and reference sites ranged from poor to excellent.

Both perimeter channel and reference sites were dominated by collector-gatherer functional feeding groups (Table 15). Perimeter channels were composed of 74\% 
collector-gatherers, $8 \%$ predators, $8 \%$ omnivores (primarily planktonic species), and 2\% shredders. Reference sites were composed of 57\% collector-gatherers, 27\% shredders, $5 \%$ predators, and 3\% omnivores. Perimeter channel communities were composed of primarily lentic-inhabiting species while reference communities were primarily loticinhabiting species. Macroinvertebrate abundance data are reported in Appendices F-H.

NMDS analysis showed clustering of sites by site type with P_AR tending to have a community type more similar to reference sites and R_HC having a community type more similar to perimeter sites (Fig. 47). P_WO and R_WO were somewhat separate from the rest of the sites and plotted out in the positive NMDS 1 and positive NMDS 2 quadrant. Increasing selenium, ammonia, and summer discharge were significant predictors of community composition but did not seem to be associated with any particular group of sites. Additionally, WVSCI score, percent tolerant taxa, percent EPT, EPT richness, percent unknown feeding group, percent shredder, and percent omnivore were correlated with community composition (Fig. 48).

\subsection{Organic Matter Retention}

Retention was significantly higher in perimeter channels than in reference sites for measures of mean cumulative stick distance traveled, mean cumulative stick distance per day, number of sticks exiting the reach, and percent of sticks retained (Table 4, Table 16). No movement of artificial sticks or leaves was recorded in any perimeter channel sites except P_WO. Mean distance traveled by artificial leaves at P_WO was $2.60 \mathrm{~m}$. Mean cumulative distance traveled per day by artificial sticks at P_WO was $0.06 \mathrm{~m} / \mathrm{day}$. Mean cumulative distance traveled by artificial sticks was $0.00 \mathrm{~m} /$ day in perimeter 
channels, excluding P_WO, and $0.06 \mathrm{~m} /$ day in reference sites. Mean distance traveled by artificial leaves was $0.00 \mathrm{~m}$ in perimeter channels, excluding P_WO, and $0.42 \mathrm{~m}$ in reference sites. Overall retention rate was not significantly different between site types. Perimeter channels averaged a rate of -0.064 and reference sites averaged -0.020 .

\subsection{Dissolved Carbon}

\section{Dissolved Organic Carbon}

Perimeter channels averaged higher dissolved organic carbon (DOC) concentrations than reference sites (Table 17, Fig. 49), but only mean winter DOC levels were significantly higher in perimeter channels than reference sites (Table 4). Mean DOC for three seasons with water was $3.27 \pm 2.09 \mathrm{mg} / \mathrm{L}$ for perimeter channels and 1.51 $\pm 0.64 \mathrm{mg} / \mathrm{L}$ for reference sites. Statistically significant trends were shown for DOC in regards to season (Table 7). Seasonal DOC was not correlated with seasonal discharge as expected (McDowell \& Likens 1988c, Collier et al. 1989, Hinton et al. 1997, Meyer et al. 1998, Dawson et al. 2002, Spencer et al. 2007).

\section{$\underline{\text { Total Carbon }}$}

Total Carbon (TC) measures were statistically higher in perimeter channels than reference sites for all seasons (Table 4, Fig. 50). Mean TC for spring, summer, and winter (reference sites did not contain enough water for sampling in autumn) was $18.5 \pm$ $2.1 \mathrm{mg} / \mathrm{L}$ for perimeter channels and $2.6 \pm 0.3 \mathrm{mg} / \mathrm{L}$ for reference sites (Table 18).

\subsection{Decomposition and Processing Power}

Perimeter channels averaged $47 \pm 2 \%$ loss of organic matter after about 325 days, whereas reference sites averaged $62 \pm 19 \%$ loss (Table 19). Reference sites lost $41 \%$ 
(R_HC) (200 days), 89\% (R_LF), 71\% (R_ME), 63\% (R_MW), and 48\% (R_WO) (Fig. 51). However, when calculated, neither the decomposition rate nor the percent organic mass lost were significantly different at a 95\% confidence interval. When the effects of conductivity were removed, however, mean total weight of litter bags after 325 days was significantly different between site types (Table 11).

The mean calculated decomposition rate for perimeter channels was $-0.00213 \pm$ 0.00038 and the mean rate for reference sites was $-0.00348 \pm 0.00196$. Figure 52 shows the rates for each site. These rates are within the range of 0.0014-0.021 suggested by Beiser et al. (1991) and D’Angelo and Webster (1992). Decomposition rate was positively correlated with WVSCI score, percent EPT, percent unknown invertebrates, total number of adult amphibians, total number of adult amphibian species, mean percent of organic matter lost, and mean cumulative stick distance (Table 20). Percent shredders was not correlated with decomposition as expected (Table 20). Additionally, ANCOVA analysis revealed significant interactions between site type and site conductivity for decomposition rate, mean percent organic matter remaining, and mean percent of organic matter lost (Table 11, Fig. 53-55).

Overall processing power was not statistically different between site types (Table 4). Processing power averaged 0.013 in perimeter channels and 0.007 in reference sites (Table 19).

\subsection{Structural Changes over Time}

Overall, few correlations between perimeter channel characteristics and age since reclamation were observed. Chloride and sodium (Fig. 56) were correlated with age 
primarily because of elevated levels within the oldest site P_BH. TDS and conductivity (Fig. 57) were not correlated with age since reclamation; conductivity remains elevated over time. In terms of vegetative community structure, percent cattail was correlated with age as well as percent fern, species per $\mathrm{km}^{2}$, and trees per $\mathrm{km}^{2}$ (Fig. 58 \& 59). However, correlations of the former three categories are due to zero values for all sites except for P_BH. Macroinvertebrate community structure showed significant correlation with age since reclamation in terms of total family richness (Fig. 60). Correlation with percent filterer was due to $2 \%$ presence in P_ST and $8 \%$ in P_BH. Percent tolerant species and percent chironomid were not correlated with age (Fig. 61). Total adult amphibian species and percent grassland amphibians were negatively correlated with age since reclamation (Fig. 62). No decomposition parameters were correlated with age since reclamation.

\subsection{The Effects of Elevated Conductivity}

Conductivity and associated parameters were some of the most outstanding differences between site types. ANCOVA analysis was run on decomposition and biotic metrics to determine any confounding effects of elevated conductivity levels on measures within sites. Significant interactions between site type and conductivity were found for decomposition rate, mean percent organic matter after 325 days, mean percent organic mass lost, WVSCI score, percent EPT, EPT richness, total invertebrate richness, amphibian richness, larval amphibian richness, total number of amphibians, mean number of amphibians, total number of larval amphibians, mean amphibian density, and percent forest-utilizing amphibians (Table 11). Additionally, mean total weight after 325 
days, WVSCI score, percent EPT, EPT richness, amphibian richness, and larval amphibian richness were found to be significantly different by mean conductivity.

\subsection{Ecological Units}

EUs were calculated from parameters deemed to be important characterizers between perimeter and reference sites. Among those with means greater in perimeter channels were percentage of mean larval amphibian biomass, mean conductivity, retention rate, mean DOC, processing power, lentic amphibian species, and macroinvertebrate species richness. Those with means greater in reference sites were invertebrate biomass, WVSCI score, decomposition rate, EPA RBP, EPT richness, percentage EPT, and percentage of lotic amphibian species (Table 21).

\subsection{Discussion}

\subsection{Key Concerns}

Elevated conductivity appeared to be the primary determinant of reduced biological conditions and ecosystem processes in reclaimed perimeter channels. ANCOVA analysis revealed key interactions between site type (perimeter channel and reference site) and conductivity with regards to OM decomposition and invertebrate and amphibian metrics (Table 11).

\section{The Effect Conductivity and Site Type on Decomposition}

Although not previously indicated in published literature, ANCOVA analysis indicated a significant effect of site type and conductivity on OM decomposition rate (Table 11). Overall analysis indicated that conductivity may be influencing 
decomposition rate in perimeter channels, possibly through reduced microbial activity. Simon et al. (2009) found differences in stream OM decomposition rates along a pH gradient. They determined that reduced decomposition was the result of altered microbial assemblages and reduced microbial activity under low $\mathrm{pH}$ conditions (Simon et al. 2009). Additional studies have linked reduced microbial biomass and respiration with reduced decomposition rates within acidified streams (Mulholland et al. 1987, Griffith \& Perry 1994, Meegan et al. 1996, Niyogi et al. 2001). Although the sites in this study did not suffer from reduced pH (except for R_WO), increased conductivity may have similar effects on microbial community structure, biomass, or respiration.

\section{The Effect Conductivity and Site Type on Macroinvertebrates}

Within the central Appalachian region, the order Ephemeroptera usually account for $25-50 \%$ of the total spring macroinvertebrate community in relatively undisturbed headwater streams (Pond et al. 2008). Ephemeroptera have also been found to show the greatest response to increases in specific conductivity in waters affected by surface mining within the region (Hartman et al. 2005, Pond et al. 2008). Consistent with previous studies, the relatively undisturbed reference sites contained a significantly higher percentage of EPT than perimeter channel sites. Additionally, a significant interaction between site type and conductivity was shown for WVSCI score, percent EPT, EPT richness, and total invertebrate richness (Table 11). EPT species are considered taxa indicative of good water quality and many cannot be supported in perimeter channel sites due to conversion from lotic to lentic conditions in addition to elevated TDS and specific conductivity (Pond et al. 2008). One possible mechanism for 
this is the relationship between elevated conductivity and interference with the osmoregulation of macroinvertebrates (Wichard 1973, McCulloch 1993).

The shift in community composition from a community supporting a large percentage of shredders to a community supporting a large percentage of collector gatherers (primarily chironomids) may have downstream implications. Shredders play an important role within the aquatic continuum by feeding on coarse particulate organic matter (CPOM) and converting it to fine particulate organic matter (FPOM) (Cummins \& Klug 1979). FPOM, in turn, is exported as a food resource base for collector-gatherers (Short \& Maslin 1977). If the shredder community is lost or reduced, shortcomings in trophic linkages may affect the entire aquatic ecosystem.

\section{The Effect Conductivity and Site Type on Amphibians}

Elevated conductivity levels also had a significant influence on amphibian assemblage composition. Specifically, a strong interaction was shown between conductivity and site type for the numbers of amphibians (primarily larva), overall richness, amphibian density, and percent of forest-utilizing species (Table 11). Most of these metrics are associated with the larval component of the amphibian population. These metrics are quantitative indicators of the shift in community compositions between site types. Differences in water chemistry such as elevated sulfate, calcium, magnesium, and alkalinity, however, did not seem to deter amphibians from using these sites overall.

The difference in number of adults versus larval amphibians at the two site types can be explained by the differences in the communities that both inhabit and use the aquatic features. Reference sites were inhabited by stream salamanders that live and 
breed within the stream. The difference in quantity of adults and larva at these sites may be due to the ability to more easily locate and capture the larger, adult salamanders as well as the relatively small number of eggs deposited by these salamander species ( $\sim 20)$ (Green \& Pauley 1987). The large quantity of larval versus adult amphibians in perimeter channels may be explained by the utilization of these sites by both lentic-using species as well as tree frogs inhabiting adjacent, intact forests that utilize these lentic sites

for breeding. Both lentic frogs and tree frogs may lay as many as 1000-2000 eggs (Green \& Pauley 1987). Frog larva are more easily captured than stream salamander larva as they tend to congregate at pond margins and are more visible. Additionally, frog adults are harder to locate and capture than their larva.

\subsection{Ecological Units}

To assist with quantitative calculation of on-site shortcomings, EUs have been developed. EUs present a proportional difference in measures found at perimeter channel sites versus those found at reference sites. The differences represent aspects of the original site that have been lost and would be difficult to restore on-site because of the conversion of low TDS lotic channels to high TDS lentic channels. Overall the EUs show that perimeter channels were functionally similar to reference channels in terms of amphibian biomass and OM processing. Substantial shortcomings were present with regards to species composition shifts, losses of sensitive invertebrate taxa, and overall invertebrate taxa richness. Attempts to compensate for shortcomings captured in the ratios by re-constructing stream structure on-site are ill-advised because of the difficulties associated with constructing a lotic system "from scratch" (Palmer et al. 2009). 
Therefore, perimeter channels should be designed as lentic systems and EUs should be applied to sites outside the mine permit boundary on an aquatic surface area basis (Merovich \& Petty 2007). For example, to compensate for a reduction in overall WVSCI score, off-site mitigation projects to enhance lotic habitat for invertebrates can be conducted at a rate of 1 meter of mitigation for every $0.71 \mathrm{~m}$ of perimeter channel. The application of EUs at a watershed scale may allow off-set of functional and structural losses that occur despite reclamation efforts.

\subsection{Reclamation Successes}

Amphibian Community

Perimeter channel and reference sites supported two very different amphibian community types, however, overall diversity and number of species supported was comparable. Perimeter channels supported a majority of generalist species, such as Rana clamitans (green frog) and Notophthalmus v. viridescens (red spotted newt), and tree frog larva such as Hyla chrysoscelis (Cope’s gray tree frog). Reference sites supported stream salamanders, primarily Desmognathus monticola (seal salamander) and Desmognathus fuscus (northern dusky salamander).

Overall, preferences of the species themselves to use or inhabit lentic versus lotic waters were the driving factors of community composition. Primarily those species that prefer lotic habitats were found in reference sites and those species preferring lentic habitats for breeding or feeding were found in perimeter channel habitats. However, the vegetational differences between these site types may be the second most important characteristic. The amphibian community structure is highly correlated to the type and 
quality of vegetation present. Young, sparsely vegetated perimeter channels (such as P_WO) did not support larval amphibians despite being equally as close to intact forest as other perimeter channel sites.

In terms of number of species, both site types supported an average of two larval species and approximately two adult species. Overall diversity remained the same; however, there was an unmistakable shift in community type. Lotic and forest species were replaced by grassland-inhabiting, lentic species. Perimeter channels supported the larva of forest species such as Hyla chrysoscelis (Cope's gray tree frog) and Pseudacris c. crucifer (northern spring peeper) (Table 13, Appendix D). These sites most likely benefited from close proximity to intact forest (Hecnar \& M’Closkey 1996, Stevens et al. 2002). Constructed wetlands have been reported to be colonized by ubiquitous anurans such as gray tree frog, American toad, spring peeper, and Rana catesbeiana (American bullfrog) within two years of creation (Perry et al. 1996, Mierzwa 2000, Pechmann et al. 2001). All of the perimeter channels in this study were older than three years since reclamation and showed colonization by amphibians. No positive correlation between amphibian community metrics and age since reclamation was found. Negative correlations were shown between total adult amphibian species and percent of grassland amphibians and age since reclamation (Table 4). This means that the number of adult amphibians, presumably grassland species, reduced over time. It is difficult to determine why this might have occurred by sampling five perimeter channels. As the perimeter channels age, there may be a significant change in an unmeasured parameter such as mean water depth or cattail density that dissuaded use by grassland adults. 
The colonization by amphibians shortly after wetland establishment is consistent with patterns found in accidentally formed and constructed wetlands (Kent \& Langston 2000, Pollio 2005). Although other studies found greater numbers of species in these wetlands than we found (Pollio 2005), this study found six of nine species expected to occur in grassland areas (Table 13). Additionally, studies have shown the number of amphibian species found in newly created pools was positively correlated with the distance of these pools to forests (Laan \& Verboom 1990). As the perimeter channels in this study were not intentionally designed as wetlands to support amphibians, considering wetland habitat during perimeter channel construction may lead to an increase in the number of species using the wetlands, as long as minimal distance to intact forest is maintained.

Macroinvertebrate Community

Perimeter channels and reference sites had similar macroinvertebrate family richness and biomass but significantly different community composition. Perimeter channels overall, however, supported a comparable number of macroinvertebrates and number of species. Perimeter channels were dominated by lentic species, such as Odonates, and were dominated by collector-gathers (primarily chironomids). Reference sites were dominated by lotic species and had a higher percentage of shredders than perimeter channel sites.

\section{Decomposition and Carbon Cycling}

Mean decomposition rates for both site types were within ranges suggested by Beiser et al. (1991) and D’Angelo and Webster (1992). OM decomposition rates showed 
a significant overall effect of site type and mean conductivity. Decomposition rates were not, however, correlated with parameters known to affect decomposition such as temperature, nutrient concentration, hydrology, dissolved oxygen, percentage of shredders, or pH (Whiles \& Wallace 1997, Graça et al. 2001, Swan 2004, Simon et al. 2009) (Table 4). However, these parameters were also not significantly different between site types with the exception of summer $\mathrm{pH}$ and spring discharge. Although discharge did not differ between site types, hydrology in terms of lentic versus lotic systems did. Therefore, it is likely that, the difference in aquatic system type itself affects the potential breakdown rate between perimeter channel and reference site types.

Field observations over the course of the study support the idea that the lotic component to sites contributed to their overall loss of organic matter. The position of the bags and securing rope in relation to the rebar stake, the amount of movement from the original placement, the degree of distress to the mesh bag, and the integrity of the remaining material indicate that the majority of material lost from reference site bags was lost through mechanical abrasion.

The difference in the degree of water flow between site types is evidenced by differences in organic matter retention. No movement of artificial sticks or leaves was recorded at any perimeter channel sites except P_WO (which has the highest gradient of perimeter channels) (Table 16). Of the perimeter channel sites, P_WO also had the highest decomposition rate (Table 19). Overall distance traveled by artificial sticks and leaves was greater in reference sites than in perimeter channels. 
Winter DOC levels in perimeter channels were statistically higher than in reference sites, despite a loss of original topsoil. Because of the relation between DOC and soil type and chemistry (McDowell \& Likens 1988, Dawson et al. 2002, Ankers et al. 2003), it is unlikely that the DOC in perimeter channel systems originates from the soil of the reclaimed site. Perimeter channel DOC is also unlikely to originate from leaf litter inputs as found by Hongve (1999). Perimeter channels have a low percent canopy cover and are usually at or above the canopy height of adjacent intact forest.

This knowledge, along with comparable processing power rates between site types, indicates that the high DOC concentrations within perimeter channels is most likely originating from on-site inputs of detritus from aquatic macrophytes. Specifically, the high percent cover emergent vegetation and higher retention capability of perimeter channels allows organic material to be effectively cycled within the perimeter channels Anderson and Mitsch (2006) found that the percentage of soil organic matter content within riverine wetlands increased about one percent every three years. This concurs with correlations in this study between age since reclamation and percent cattail (Table 4). The high retention ability of these sites combined with increasing cattail coverage may lead to increased mean DOC concentrations with age since reclamation. This trend is seen in all but the oldest site (P_BH) (Table 17).

Perimeter channels overall resemble wetlands more than streams. Because wetlands of this type are uncommon within West Virginia, it may be difficult to evaluate their function as wetlands. An expected range of DOC levels, especially, may be difficult to evaluate without local reference wetlands because of the complexity of parameters that 
determine DOC concentration as well as the natural DOC flux inherent from environmental conditions. For instance, Mann and Wetzel (1995) found DOC levels fluctuated naturally with seasonal macrophyte growth and bacterial production within riverine wetlands. Additionally, geographic region, elevation, season, and degree of exposure may influence local DOC fluctuation.

Seasonal DOC concentration was not correlated with seasonal discharge as expected (McDowell \& Likens 1988c, Collier et al. 1989, Hinton et al. 1997, Meyer et al. 1998, Dawson et al. 2002, Spencer et al. 2007). This may be due to the mining disturbance at perimeter channel sites resulting in large, reclaimed catchments with relatively low OM inputs from tree canopies. Reference site concentrations were within the range of $0.673-2.94 \mathrm{mg} / \mathrm{L}$ for forested watersheds within the region (Meyer \& Tate 1983; Tate \& Meyer 1983). Perimeter channel mean concentrations were less than annual mean concentrations of $9.8 \pm 1.5 \mathrm{mg} / \mathrm{L}$ for wetland-dominated watersheds reported by Eimers et al. (2008). Both mean concentrations, however, are comparable to mean annual concentrations ranging from $7.1-48.2 \mathrm{mg} / \mathrm{L}$ within the ponded portion of riverine wetlands (Mann \& Wetzel 1995).

\subsection{Are Ecological Functions Reclaimed Locally?}

The process of site reclamation is intended to offset any geomorphic or ecological losses (Bradshaw 1984, Holl 2002). Although full re-creation of the original topography of an area during reclamation is considered the geomorphic ideal, it is not always appropriate, or feasible, in steeper areas (Nicolau 2003). Ecologically, Hilderbrand et al. (2005) urge the setting of realistic restoration goals and argue that "scientifically 
defensible end points of functional or structural equivalence” need to be set. In the case of mountaintop removal mining in West Virginia, the site is converted from a steep, forested headwater stream to an unforested site with rolling terrain and wetland-like aquatic features. Despite this conversion, the question remains if ecological functions such as supporting biological communities and downstream energy export are adequately reclaimed.

Functional downstream export of carbon is supported by the on-site generation of DOC. Higher retention capabilities of perimeter sites allows for increased opportunity for decomposition. Overall processing power is comparable in perimeter sites and reference sites. Mechanical breakdown of OM is lost, but decomposition rates are comparable.

In terms of biotic communities, both amphibians and macroinvertebrates showed similar diversities on mined and unmined sites. However, communities shifted from lotic communities supporting sensitive taxa to lentic communities supporting generalists and tolerant taxa. Any retention of biotic communities by perimeter channels may be favorably influenced by the proximity of intact forest. These areas may encourage biotic use of perimeter sites and act as a source for colonizers.

\subsection{Watershed Scale Perspective}

The change in site type from forested stream to perimeter channel resulted in a shift in vegetation, amphibian, and macroinvertebrate composition that cannot be reclaimed on-site. The new system cannot support the same community types. In 
response to the loss of pre-existing communities, off-site mitigation that supports healthy, native biotic communities must be pursued.

Additionally, the shift in communities from lotic, sensitive taxa to lentic, generalist taxa may become problematic as the cumulative effects from stream to stream and watershed to watershed are considered over a region (Lowe \& Bolger 2002, Lowe et al. 2006, Pond et al. 2008). Disturbance at a local scale may influence the ability of populations to re-colonize at a regional scale (Lowe \& Bolger 2002). Although prevention of species loss at a local scale may not be possible, it can be prevented at the watershed scale. Consideration must be given to protect portions of a mined watershed to act as sites for wildlife protection and source populations for continued re-colonization (Lowe et al. 2006, Pond et al. 2008). Consideration must be given both to the extent of the watershed affected and to the life histories of at-risk species to determine regional habitat needs (Lowe et al. 2006). Ensuring the connectivity of first-order streams may be essential for ensuring the survival of some species, such as Gyrinophilus porphyriticus (spring salamander) (Lowe \& Bolger 2002, Lowe et al. 2006).

The change in water chemistry resulting in increased alkalinity, manganese, TDS, calcium, magnesium, sulfate, and specific conductivity also cannot be reclaimed on-site. This increase in water parameters can be a compounded problem in the watershed as a whole depending on the extent to which the watershed is mined. Pond et al. (2008) found that the evidence of mining and reclamation on the water chemistry (especially specific conductivity) was greatly reduced in watersheds that contained a higher percentage of unmined tributaries. The best way to handle changes in water chemistry resulting from 
watershed scale disturbance may be dilution at a watershed scale, primarily through planned protection of headwater streams (Saunders et al. 2002. Lowe et al. 2006). By preserving a percentage of tributaries within the mined watershed as undisturbed sites and sources of dilute water, cumulative downstream changes in water chemistry may be avoided (Saunders et al. 2002, Merriam 2009). This may be an especially pertinent solution because mining and its effects may not be the only stressor to local watersheds within the region. Historical mining and non-residential development may compound watershed-wide stresses to ecological function (Merriam 2009).

\subsection{Reference Site Condition}

Reference sites were selected for this study based on winter and spring water chemistry measures, topographic maps, and a general knowledge of the area. The reference streams selected were known to drain watersheds with no surface mining activities and no residential development. Preliminary measures of water quality indicated that all streams were in reasonably good condition for streams in this region.

Unfortunately, two of the reference sites, R_HC and R_WO, later displayed water chemistry that was less than ideal. R_WO had lower than average $\mathrm{pH}$ as well as higher acidity, aluminum, manganese, calcium, manganese, conductivity, and sulfate than other reference sites. The water chemistry of this site is indicative of streams impacted by acid mine drainage (Merovich et al. 2007). Consequently, this site is presumed to be influenced by historic underground mining. It is not clear why initial water quality measures did not show signs of impairment. However, we know from studies in other watersheds that water quality in streams impacted by acid mine drainage (AMD) can vary 
significantly from one season to the next (Merovich et al. 2007). The poor water quality conditions of R_WO likely contributed to measures of organic matter decomposition, and amphibian and macroinvertebrate diversity that were substantially lower than those of other reference sites.

Another reference site, R_HC, was impacted by some unknown, non-mining related disturbance upstream in summer 2008. During this period, a natural gas line and access road were installed and waste water from gas well drilling may have been introduced to the stream. Prior to disturbance, R_HC possessed water quality characteristics very similar to the other high quality reference sites. Following disturbance, all pore spaces within the R_HC stream bed were filled with sediment resulting in loss of habitat for amphibians and macroinvertebrates. Additionally, R_HC water chemistry measures showed an increase in nitrite, conductivity, barium, sodium, and chloride.

Although R_HC and R_WO possessed less-than-ideal biotic and abiotic conditions, these sites were included in most analyses comparing un-mined reference stream channels to reclaimed mine perimeter channels. Excluding them would have reduced our sample size from five to three and made direct comparisons between site types difficult. In addition, we believe that the range of conditions observed at reference sites is representative of streams draining watersheds that have not been surface mined (Minter 2009, Merriam 2009). Because of the topography and geology of the area, it is likely that one in five watersheds in the region will be affected by legacy impacts from 
underground mining and increasingly streams are being impacted by gas extraction or other non-mining related disturbance (Merriam 2009).

\subsection{Additional Questions}

Previous literature has emphasized the connectivity of upstream functional and ecological processes to downstream ecosystem function and value (Vannote et al. 1980, Gomi et al. 2002, Lowe et al. 2006, Meyer et al. 2007, Wipfli et al. 2007). If downstream functions and values are to be maintained, the watershed function as a whole must be considered (Lowe \& Bolger 2002, Saunders et al. 2002, Lowe et al. 2006, Pond et al. 2008). The functions considered by this study were the downstream export of energy in terms of on-site OM retention and decomposition and off-site DOC export and the support of biologic community structure and diversity. Additional studies may seek to understand possible losses in function of the downstream export of particulate organic matter (POM), emphasized by Vannote et al. (1980), and gaps in ecological function originating from the physical gap between perimeter channel off-site outflow points and native stream channels.

Native channels act as a source of coarse and fine particulate organic matter (CPOM/FPOM) for downstream trophic webs (Cummins \& Klug 1979, Vannote et al. 1980, Cummins et al. 1989, Wallace et al. 1997). This is generated by macroinvertebrate activity as well as mechanical breakdown of organic matter. Since perimeter channels have a different macroinvertebrates community than reference sites, and because the mechanical component caused by lotic waters is lost, there may be an additional 
functional loss of CPOM/FPOM export. Additional studies may investigate potential shortcomings in CPOM and FPOM production and export.

The reclaimed perimeter channels in this study consisted of retained water prevented from escaping off the mine perimeter by berms. These features drained towards a central point where an off-site flow was created by perforating the berm. The water was then allowed to drain off-site, downhill and rejoin native streams. The physical area in between the point where water exits the reclaimed site and rejoins native channels may act as an additional site of disturbance as no native channel exists and exported water creates a new channel. Future studies may seek to measure the differences in water chemistry between the uphill off-site flow point and the junction where the flow joins native channels. Specifically, what changes in DOC may occur between those two points? Additionally, does the transitional zone allow for increases or decreases in TDS, total suspended solids (TSS), and specific conductivity?

The reclaimed perimeter channels in this study resemble wetlands. However, no comparison was made between the ecological function of these sites as wetlands and the ecological function of similar wetlands within the region. Rough comparisons can be made via published literature. Overall, DOC concentrations and decomposition rates were comparable to published values (Beiser et al. 1991, D’Angelo \& Webster 1992, Mann \& Wetzel 1995). The DOC concentrations and decomposition rates expected for wetlands within the study site may differ, however, because of regional factors such as elevation, growing season, geology, etc. Future studies may seek to compare perimeter site function to the function of comparable wetlands within the region. 
This study also did not investigate differences in the functions of perimeter channels in terms of their overall construction and design. Comparison to native wetlands may aid in guiding design suggestions such as recommended percent of open water and water depth. At this point, variation exists from site to site in terms of how mine sites are reclaimed and how perimeter channels are designed. These differences seem to originate from both the time period of the reclamation and the company performing the reclamation. Future studies may seek to discover if increases in functional recovery can be gained simply by perimeter channel design. Specifically, can conductivity and TDS be further reduced on-site and can intentional design increase the diversity and structure of biotic communities?

\subsection{Summary}

Although perimeter channels support on-site biotic communities, decomposition rate, and processing power comparable to pre-mining condition, the manner of conducting these ecological functions differs. Perimeter channels have lost lotic components that aid in OM decomposition and downstream transport. Biotic communities have shifted from supporting sensitive, lotic taxa to supporting generalist, lentic taxa. Increases in water chemistry parameters such as alkalinity, conductivity, and related parameters cannot be mitigated for on-site and must be considered at a watershed scale. Native headwater streams within the affected watershed must be protected to act as refugia and source populations for biota and sources of fresh-water for the watershedwide dilution of exported water. Off-site mitigation can compensate for on-site shortcomings through the application of EUs. Additional research may provide insights 
into the linkages between perimeter channels and native catchments and suggestions for future perimeter channel design. 


\subsection{Literature Cited}

Allen, E. B., J. S. Brown, and M. F. Allen.2001. Restoration of plant, animal and microbial diversity. Pages 185-202 in Encyclopedia of Biodiversity, S. Levin, editor, Academic Press, San Diego, CA.

Anderson, N. H. 1992. Influence of disturbance on insect communities in Pacific Northwest streams. Hydrobiologia 248:79-92.

Anderson, C. J., and W. J. Mitsch. 2006. Sediment, carbon, and nutrient accumulation at two 10-year-old created riverine marshes. Wetlands 26:779-792.

Andrews, J. 1992. Soil productivity model to assess forest site quality on reclaimed surface mines. Thesis. Virginia Polytechnic Institute and State University, Blacksburg, VA.

Ankers, C., D. E. Walling, and R. P. Smith. 2003. The influence of catchment characteristics on suspended sediment properties. Hydrobiologia 494:159-167.

Ashby, W. C. 1964. Vegetation development on a strip-mined area in southern Illinois. Illinois State Academy of Science Transcript. 57:78-83. 
Atkinson, R. B., and J. J. Cairns. 1994. Possible use of wetlands in ecological restoration of surface mined lands. Journal of Aquatic Ecosystem Stress and Recovery 3:139-144.

Baker, J. P., J. Van Sickle, C. J. Gagen, D. R. DeWalle, W. E. Sharpe, R. F. Carline, B. P. Baldigo, P. S. Murdoch, D. W. Bath, W. A. Kretser, H. S. Simonin, and P. J. Wigington. 1996. Episodic acidification of small streams in the Northeastern United States: effects on fish populations. Ecological Applications 6:422-437.

Balcombe, C. K., J. T. Anderson, R. H. Fortney, and W. S. Kordek. 2005a. Aquatic macroinvertebrate assemblages in mitigated and natural wetlands. Hydrobiologia 541:175-188.

Balcombe, C. K., J. T. Anderson, R. H. Fortney, and W. S. Kordek. 2005b. Vegetation, invertebrate, and wildlife community rankings and habitat analysis of mitigation wetlands in West Virginia. Wetlands Ecology and Management 13:517-530.

Balcombe, C. K., J. T. Anderson, R. H. Fortney, J. S. Rentch, W. N. Grafton, and W. S. Kordek. 2005. A comparison of wetland plant communities in mitigation and reference wetlands in the Mid-Appalachians. Wetlands 25:130-142.

Barbour, M. T., J. Gerritsen, B. D. Snyder, and J. B. Stribling. 1999. Rapid bioassessment protocols for use in streams and wadeable rivers: periphyton, benthc macroinvertebrates, 
and fish. EPA/Second ed. United States Environmental Protection Agency, Washington, D.C.

Batzer, D. P., B. J. Palik, and R. Buech. 2004. Relationships between environmental characteristics and macroinvertebrate communities in seasonal woodland ponds of Minnesota. Journal of the North American Benthological Society 23:50-68.

Beiser, M. C., S. Testa III, and N. G. Aumen. 1991. Macroinvertebrate trophic composition and processing of four leaf species in a Mississippi stream. Journal of Freshwater Ecology 6:23-33.

Bell, T. J., and I. A. Ungar. 1981. Factors affecting the establishment of natural vegetation on a coal strip mine spoil bank in southeastern Ohio. American Midland Naturalist 105:19-31.

Benfield, E. F. 1996. Leaf breakdown in stream ecosystems. Pages 579-589 in F.R. Hauer, and G. A. Lamberti. Methods in stream ecology. Academic Press, Inc. San Diego, CA.

Benfield, E. F., and J. R. Webster. 1985. Shredder abundance and leaf breakdown in an Appalachian mountain stream. Freshwater Biology 15:113-120. 
Bernhardt, E. S., E. B. Sudduth, M. A. Palmer, J. D. Allan, J. L. Meyer, G. Alexander, J. Follstad-Shah, B. Hassett, R. Jenkinson, R. Lave, J. Rumps, and L. Pagano. 2007. Restoring rivers one reach at a time: results from a survey of U.S. restoration practitioners. Restoration Ecology 15:482-493.

Black, P. E. 1997. Watershed functions. Journal of the American Water Resources Association 33:1-11.

Blevins, D. W. 1991. Hydrology and water chemistry of an abandoned surface coal mine, Southwestern Henry County, Missouri- 1984-86. USGS/Water-Resources Investigations Report 90-4047: 59. United States Geological Survey, Rolla, MO.

Bonta, J. V. 2000. Impact of coal surface mining and reclamation on suspended sediment in three Ohio watersheds. Journal of the American Water Resources Association 36:869887.

Bonta, J. V., and W. A. Dick. 2003. Impact of coal surface mining and reclamation on surface water chemical concentrations and load rates in three Ohio watersheds. Journal of the American Water Resources Association 39:793-815.

Bradshaw, A. D. 1984. Land restoration: now and in the future. Proceedings of the Royal Society of London B, 223, 1-23. 
Bradshaw, A. D. 1996. Underlying principles of restoration. Canadian Journal of Fisheries and Aquatic Sciences 53:3-9.

Brenner, F. J., M. Werner, and J. Pike. 1984. Ecosystem development and natural succession in surface coal mine reclamation. Ministry of the Environment 6:10-22.

Brix, H. 1994. Functions of macrophytes in constructed wetlands. Water Science and Technology 29:71-78.

Brown, J. H., and A. Kodricbrown. 1977. Turnover rates in insular biogeography: effect of immigration on extinction. Ecology 58:445-449.

Bruns, D. A. 2005. Macroinvertebrate response to land cover, habitat, and water chemistry in a mining-impacted river ecosystem: a GIS watershed analysis. Aquatic Sciences 67:403-423.

Burger, J. A., and J. L. Torbert. 1990. Mine land reclamation for wood production in the Appalachian region. Pages 159-163 in J. Skousen, J. Sencindiver, and D. Samuel, editors. Proceedings of the 1990 Mining and Reclamation Conference and Exhibition, Volume I. West Virginia University, Morgantown, WV. 
Chambers, J. C., R. W. Brown, and B. D. Williams. 1994. An evaluation of reclamation success on Idaho’s phosphate mines. Restoration Ecology 2:4-16.

Clark, M. J., M. S. Cresser, R. Smart, P. J. Chapman, and A. C. Edwards. 2004. The influence of catchment characteristics on the seasonality of carbon and nitrogen species concentration in upland rivers of Northern Scotland. Biogeochemistry 68:1-19.

Clarke, K. R. 1993. Non-parametric multivariate analyses of changes in community structure. Australian Journal of Ecology 18:117-143.

Connell, J. H., and R. O. Slatyer. 1977. Mechanisms of succession in natural communities and their role in community stability and organization. American Naturalist 111:1119-1141.

Cole, C. A., and E. A. Lefebvre. 1991. Soil and water characteristics of a young surface mine wetland. Environmental Management 15:403-410.

Collier, K. J., R. J. Jackson, and M. J. Winterbourn. 1989. Dissolved organic carbon dynamics of developed and undeveloped wetland catchments in Westland, New Zealand. Archiv für Hydrobiologie 117:21-38. 
Courtemanch, D. L. 1996. Commentary on the subsampling procedures used for rapid bioassessments. Journal of the North American Benthological Society 15:381-385.

Creed, I. F., S. E. Sanford, F. D. Beall, L. A. Molot, and P. J. Dillon. 2003. Cryptic wetlands: integrating hidden wetlands in regression models of the export of dissolved organic carbon from forested landscapes. Hydrological Processes 17:3629-3648.

Crump, M. L., and Scott, N. J., Jr. 1994. Standard techniques for inventory and monitoring: visual encounter surveys. Pages 84-92 in W. R. Heyer, M. A. Donnely, R. W. McDiarmid, L. C. Hayek, and M. S. Foster, editors. Measuring and monitoring biological diversity. Standard methods for amphibians. Smithsonian Institution, Washington, D.C.

Cummins, K. W., M. A. Wilzbach, D. M. Gates, J. B. Perry, and W. B. Taliferro. 1989. Shredders and riparian vegetation. BioScience 39:24-30.

Cummins, K. W., and M. J. Klug. 1979. Feeding ecology of stream invertebrates. Annual Review of Ecology, Evolution, and Systematics. 10:147-172.

Cushman, S. A. 2006. Effects of habitat loss and fragmentation on amphibians: a review and prospectus. Biological Conservation 128:231-240. 
Daniels, W. L., and D. F. Amos. 1981. Mapping, characterization and genesis of mine soils on a reclamation research area in Wise County, Virginia. Pages 261-265 in Symposium on Surface Mining Hydrology, Sedimentology and Reclamation. University of Kentucky, Lexington, KY.

D’Angelo, D. J., and J. R. Webster. 1992. Natural and constrainment-induced factors influencing the breakdown of dogwood and oak leaves. Hydrobiologia 237:39-46.

Davis, J. D., P. Horwitz, R. Norris, B. Chessman, M. McGuire, B. Sommer, and K. Trayler. 1999. Wetland bioassessment manual (macroinvertebrates). National Wetlands Research and Development Program. Land and Water Resources Research and Development Corporation, Canberra, Australia.

Davidson, W. H., R. J. Hutnik, and D. E. Parr. 1984. Reforestation of mined land in the northeastern and north-central U.S. North. Journal of Applied Forestry 1:7-11.

Dawson J. J. C., M. F. Billett, C. Neal, and S. Hill. 2002. A comparison of particulate, dissolved and gaseous carbon in two contrasting upland streams in the UK. Journal of Hydrology 257:226-246. 
Deely, D. J., and F. Y. Borden. 1973. High surface temperatures on strip-mine soils. Pages 69-79 in R. J. Hutnik, and G. Davis, editors. Ecology and reclamation of devastated land. Gordon and Breach, New York, NY.

deMaynadier, P. G. and M. L. Hunter Jr. 1999. Forest canopy closure and juvenile emigration by pool-breeding amphibians in Maine. Journal of Wildlife Management 63:441-450.

Dick, W. A., J. V. Bonta, F. Haghiri, J. R. Page. 1983. Stream water quality of two small watersheds as affected by surface coal mining. Journal of Environmental Quality 12: 351-358.

Eimers, M. C., S. A. Watmough, J. M. Buttle, and P. J. Dillon. 2008. Examination of the potential relationship between droughts, sulphate and dissolved organic carbon at a wetland-draining stream. Global Change Biology 14:938-948.

Fisher, S. G., and G. E. Likens. 1973. Energy flow in Bear Brook, New Hampshire: an integrative approach to stream ecosystem metabolism. Ecological Monographs 43:421439. 
Flory, E. A., and A. M. Milner. 1999. Influence of riparian vegetation on invertebrate assemblages in a recently formed stream in Glacier Bay National Park, Alaska. Journal of the North American Benthological Society 18:261-273.

Fulk, F., B. Autrey, J. Hutchens, J. Gerritsen, J. Bourton, C. Cresswell, and B. Jessup. 2003. Ecological assessment of streams in the coal mining region of West Virginia using data collected by the U.S. EPA and environmental consulting firms. Appendix D in Programmatic Environmenal Impact Statement on Mountaintop Mining/Valley Fills in Appalachia. United States Environmental Protection Agency, Region 3, Philadelphia, PA.

Garcia-Criado, F., A. Tome, F. J. Vega, and C. Antolin. 1999. Performance of some diversity and iotic indices in rivers affected by coal mining in northwestern Spain. Hydrobiologia 394:209-217.

Gardner, T. A., J. Barlow, and C. A. Peres. 2007. Paradox, presumption and pitfalls in conservation biology: the importance of habitat change for amphibians and reptiles. Biological Conservation 138:166-179.

Garrison, R. 1992. Reforestation at the Centralia mine: an award winning effort. Pages 624-629 in Proceedings of the $9^{\text {th }}$ Annual Meeting of the American Society for Surface Mining and Reclamation. American Society of Surface Mining and Reclamation, Princeton, WV. 
Gerritsen, J., J. Burton, and M. T. Barbour. 2000. A stream condition index for West Virginia wadeable streams. Tetra Tech, Inc., Owings Mills, MD

Gibbs, J. P. 1998. Amphibian movements in response to forest edges, roads, and streambeds in southern New England. Journal of Wildlife Management 62:584-589.

Gomi, T., R. C. Sidle, and J. S. Richardson. 2002. Understanding processes and downstream linkages of headwater systems. Bioscience 52:905-196.

Graça, M. A. S., R. C. F. Ferreira, and C. N. Coimbra. 2001. Litter processing along a stream gradient: the role of invertebrates and decomposers. Journal of the North American Benthological Society 20:408-420.

Green, N. B., and T. K. Pauley. 1987. Amphibians and reptiles in West Virginia. University of Pittsburgh Press, Pittsburgh, PA.

Griffith, M. B., and S. A. Perry. 1994. Fungal biomass and leaf litter processing in streams of different water chemistry. Hydrobiologia 294:51-61. 
Growns, I., C. Schiller, N. O’Connor, A. Cameron, and B. Gray. 2006. Evaluation of four live-sorting methods for use in rapid biological assessments using macroinvertebrates. Environmental Monitoring and Assessment 117:173-192.

Halverson, H. G., and R. C. Sidle. 1997. Cumulative effects of mining on hydrology, water quality, and vegetation. Pages 99-103 in General Technical Report NE 164. United States Department of Agriculture, Northeastern Forest Experimental Station, Newtown Square, PA.

Handel, S. N. 2003. Terrestrial plant populations of forested and reclaimed sites. Appendix in USEPA. Mountaintop mining/valley fills in Appalachia. EPA/Final Programatic Impact Statement. United States Environmental Protection Agency, Region 3, Philadelphia, PA.

Hannaford, M. J., and V. H. Resh. 1995. Variability in macroinvertebrate rapidbioassessment survey and habitat assessments in a northern California stream. Journal of the North American Benthological Society 14:430-439.

Hartman, K. J., M. D. Kaller, J. W. Howell, and J. A. Sweka. 2005. How much do valley fills influence headwater streams? Hydrobiologia 532:91-102. 
Haufler, J. B., R. L. Downing, and B. S. McGinnes. 1978. Factors influencing the revegetation success of orphan mines in southwest Virginia. Pages 287-293 in D. E. Samuel, J. R. Stauffer, C. H. Hocutt, and W. T. Mason, editors. Surface mining and fish/wildlife needs in the eastern United States. West Virginia University, Morgantown, WV.

Hecnar, S. J., and R. T. M’Closkey. 1996. Regional dynamics and the status of amphibians. Ecology 77:2091-2097.

Hemond, H. F. 1989. Wetlands as the source of dissolved organic carbon to surface waters, Berlin, 7-12 May, 1989. Dahlem workshop on organic acids in aquatic ecosystems, Berlin, Germany.

Hilderbrand. R. H., A. C. Watts, and A. M. Randle. 2005. The myths of restoration ecology. Ecology and Society 10:1-11.

Hinton, M. J., S. L. Schiff, and M. C. English. 1997. The significance of storms for the concentration and export of dissolved organic carbon from two Precambrian Shield catchments. Biogeochemistry 36:67-88. 
Hobbie, J. E., and G. E. Likens. 1973. Output of phosphorus, dissolved organic carbon, and fine particulate carbon from Hubbard Brook watersheds. Limnology and Oceanography 18:734-742.

Holl, K. D. 2002. Long-term vegetation recovery on reclaimed coal surface mines in the eastern USA. Journal of Applied Ecology 39:960-970.

Holl, K. D., and J. C. Cairns Jr. 1994. Vegetational community development on reclaimed coal surface mines in Virginia. Bulletin of the Torrey Botanical Club 121:327337.

Hongve, D. 1999. Production of dissolved organic carbon in forested catchments. Journal of Hydrology 224:91-99.

Horstman, A. J., J. R. Nawrot, and A. Woolf. 1998. Mine-associated wetlands as avian habitat. Wetlands 18:298-304.

Hose, G., E. Turak, and N. Waddell. 2004. Reproducibility of AUSRIVAS rapid bioassessments using macroinvertebrates. Journal of North American Benthological Society 23:126-139. 
Hughes, H. G. 1992. Establishment of native hardwoods on mined lands revegetated under current regulations. Page 601-606 in Proceedings of the $9^{\text {th }}$ Annual Meeting of the American Society for Surface Mining and Reclamation, Princeton, WV.

Hutchens, J. J. Jr., and J. B. Wallace. 2002. Ecosystem linkages between southern Appalachian headwater streams and their banks: leaf litter breakdown and invertebrate assemblages. Ecosystems 5:80-91.

Jones, D. H., R. B. Atkinson, J. Jr. Cairns. 1993. The distribution of wetland macrophytes in accidental wetlands on surface mined land in southwest Virginia. Virginia Journal of Science 44:148.

Karamat, R. S., D. A. Mays, and R. W. Taylor. 1998. Development of natural conditions in constructed wetlands: biological and chemical changes. Ecological Engineering 12:125-131.

Kennedy, A. J., D. S. Cherry, and R. J. Currie. 2003. Field and laboratory assessment of a coal processing effluent in the Leading Creek watershed, Meigs County, Ohio. Archives of Environmental Contamination and Toxicology 44:324:331.

Kent, D. M., and M. A. Langston. 2000. Wildlife use of a created wetland in central Florida. Florida Scientist 63:17-19. 
King, R. S., and C. J. Richardson. 2002. Evaluating subsampling approaches and macroinvertebrate taxonomic resolution for wetland bioassessment. Journal of the North American Benthological Society 21:150-171.

Krueger, C. C., and T. F. Waters. 1983. Annual production of macroinvertebrates in three streams of different water quality. Ecology 66:840-850.

Laan, R., and B. Verboom. 1990. Effects of pool size and isolation of amphibian communities. Biological Conservation 54:251-262.

Lamberti, G. A., Gregory, S. V. 1996. Transport and retention of CPOM in F. R. Hauer and G. A. Lamberti, editors. Methods in Stream Ecology. Academic Press, New York, NY.

Leedy, D. L. 1981. Coal surface mining reclamation and fish/wildlife relationships in the eastern United States 1981. FWS/OBS-80/24. United States Department of the Interior, Washington, DC.

Likens, G. E., F. H. Bormann, N. M. Johnson, D. W. Fisher, and R. S. Pierce. 1970. Effects of forest cutting and herbicide treatment on nutrient budgets in the Hubbard Brook watershed-ecosystem. Ecological Monographs 40:23-47. 
Lowe, W. H., and D. T. Bolger. 2002. Local and landscape-scale predictors of salamander abundance in New Hampshire headwater streams. Conservation Biology 16:183-193.

Lowe, W. H., G. E. Likens, and M. E. Power. 2006. Linking scales in stream ecology. BioScience 56:591-597.

Mack, J. J. 2001. Ohio rapid assessment method for wetlands v. 5.0, user's manual and scoring forms. OHEPA/WET/2001-1. Ohio Environmental Protection Agency, Division of Surface Water, 401/Wetland Ecology Unit, Columbus, OH.

Malakoff, D. 1998. Restored wetlands flunk real-world test. Science 280:371-372.

Maloney, K. O. 2005. The influence of catchment-scale disturbance on low-order streams at Fort Benning, Georgia, United States. Dissertation. Auburn University, Auburn, AL. Abstracts International Part B: Science and Engineering 65:5513.

Mann, C. J., and R. G. Wetzel. 1995. Dissolved organic carbon and its utilization in a riverine wetland ecosystem. Biogeochemistry 31:99-120. 
Maret, T. R. and D. E. MacCoy. 2002. Fish assemblages and environmental variables associated with hard-rock mining in the Coeur d'Alene River basin, Idaho. Transactions of the American Fisheries Society 131:865-884.

Maret, T. R., D. J. Cain, D. E. MacCoy, T. M. Short. 2003. Response of benthic invertebrate assemblage to metal exposure and bioaccumulation assoiated with hard-rock mining in northwestern streams, USA. Journal of the North American Benthological Society 22:5898-620.

Martin, C. W., D. S. Noel, and C. A. Federer. 1984. Effects of forest clearcutting in New England on stream chemistry. Journal of Environmental Quality 13:204-210.

Matter, W. J., and J. J. Ney. 1981. The impact of surface mine reclamation on headwater streams in southwest Virginia. Hydrobiologia 78:63-71.

McCulloch, W. L., W. L. Goodfellow, and J. A. Black. 1993. Characterization, identification and confirmation of total dissolved solids as effluent toxicants. Environmental Toxicology and Risk Assessment 2:213-227.

McCune, B., and J. B. Grace. 2002. Analysis of ecological communities. MjM Software Design, Gleneden Beach, OR. 
McDowell, W. H., and G. E. Likens. 1988. Origin, composition, and flux of dissolved organic carbon in the Hubbard Brook valley. Ecological Monographs 58:177-195.

McLachlan, S. M., and D. R. Bazely. 2001. Recovery patterns of understory herbs and their use as indicators of deciduous forest regeneration. Conservation Biology 15:98-110.

Meegan, S. K., and S. A. Perry. 1996. Periphyton communities in headwater streams of different water chemistry in the central Appalachian mountains. Journal of Freshwater Ecology 11:247-256.

Meegan, S. K., S. A. Perry, and W. B. Perry. 1996. Detrital processing in streams exposed to acidic precipitation in the Central Appalachian mountains. Hydrobiologia 339:101-110.

Merovich, G. T. Jr., and J. T. Petty. 2007. Interactive effects of multiple stressors and restoration priorities in a mined Appalachian watershed. Hydrobiologia 575:13-31.

Merovich, G. T., J. M. Stiles, J. T. Petty, P. F. Ziemkiewicz, and J. B. Fulton. 2007. Water chemistry-based classification of streams and implications for restoring mined Appalachian watersheds. Environmental Toxicology and Chemistry 26:1361-1369. 
Merriam, E. R. 2009. Mining and residential development interact to produce highly impaired stream condition in an intensively mined Appalachian watershed. Thesis. West Virginia University, Morgantown, WV.

Metzeling, L., and J. Miller. 2001. Evaluation of the sample size used for the rapid bioassessment of rivers using macroinvertebrates. Hydrobiologia 444:159-170.

Meyer, J. L., and J. O’Hop. 1983. Leaf-shredding insects as a source of dissolved organic carbon in headwater streams. American Midland Naturalist 109:175-183.

Meyer, J. L., M. J. Paul, and W. K. Taulbee. 2005. Stream ecosystem function in urbanizing landscapes. Journal of the North American Benthological Society 24:602-612.

Meyer, J. L., D. L. Strayer, J. B. Wallace, S. L. Eggert, G. S. Helfman, and N. E. Leonard. 2007. The contribution of headwater streams to biodiversity in river networks. Journal of the American Water Resources Association 43:86-103.

Meyer, J. L., and C. M. Tate. 1983. The effects of watershed disturbance on dissolved organic carbon dynamics of a stream. Ecology 64:33-44. 
Meyer, J. L., and J. B. Wallace. 2001. Lost linkages and lotic ecology: rediscovering small streams. Pages 295-317 in M. C. Press, N. J. Huntley, and S. Levin, editors. Ecology: Achievement and Challenge. Blackwell Science, Oxford, United Kingdom.

Meyer, J. L., J. B. Wallace, and S. L. Eggert. 1998. Leaf litter as a source of dissolved organic carbon in streams. Ecosystems 1:240-249.

Mierzwa, K. S. 2000. Wetland mitigation and amphibians: preliminary observations at a southwestern Illinois bottomland hardwood forest restoration site. Journal of the Iowa Academy of Science 107:191-194.

Minter, M. S. 2009. Organic matter processing and opportunities for stream mitigation in an intensively mined West Virginia watershed. Thesis. West Virginia University, Morgantown, WV.

Mitsch, W. J., and J. G. Gosselink. 2000. Wetlands. Third edition. John Wiley and Sons, New York, NY.

Mulholland, P. J., A. V. Palumbo, J. W. Elwood, and A. Rosemond. 1987. Effects of acidification on leaf decomposition in streams. Journal of the North American Benthological Society 6:147-158. 
Nicolau. J. M. 2003. Trends in relief design and construction in opencast mining reclamation. Land Degradation and Development 14:215-226.

Niyogi, D. K., W. M. Lewis, Jr., and D. K. McKnight. 2001. Litter breakdown in mountain streams affected by mine drainage: biotic mediation of abiotic controls. Ecological Applications 11:506-516.

Oksanen, J., R. Kindt, P. Legendre, B. O’Hara, G. L. Simpson, P. Solymos, H. Henry, H. Stevens, and H. Wagner. 2008. Vegan: community ecology package. R package version $1.15-0$.

Palmer, M. A. 2009. Reforming watershed restoration: science in need of application and applications in need of science. Estuaries and Coasts 32:1559-2723.

Palmer, S. M., D. Hope, M. F. Billett, J. J. C. Dawson, and C. L. Bryant. 2001. Sources of organic and inorganic carbon in a headwater stream: evidence from carbon isotope studies. Biogeochemistry 52:321-338.

Pechmann, J. H., R. A. Estes, D. E. Scott, and J. W. Gibbons. 2001. Amphibian colonization and use of ponds created for trial mitigation of wetland loss. Wetlands 21:93-111. 
Perry, M. C., C. B. Sibrel, and G. A. Gough. 1996. Wetlands mitigation partnership between an electric power company and a federal wildlife refuge. Environmental Management 20:933-939.

Petty, J. T., and D. Thorne. 2005. An ecologically based approach to identifying restoration priorities in an acid-impacted watershed. Restoration Ecology 13:348-357.

Pollio, C. A. 2005. Effects of pH and heavy metal concentrations on amphibian breeding and community structure on a reclaimed pyrite mine in northern Virginia. Catesbeiana 25:51-75.

Pond, G. J., M. E. Passmore, F. A. Borsuk, L. Reynolds, and C. J. Rose. 2008. Downstream effects of mountaintop coal mining: comparing biological conditions using family- and genus-level macroinvertebrate bioassessment tools. Journal of the North American Benthological Society 27:717-737.

Pope, S. E., L. Fahrig, and H. G. Merriam. 2000. Landscape complementation and metapopultion effects on leopard frog populations. Ecology 81:2498-2508.

Prasad, M. N. V., and H. M. D. O. Freitas. 1999. Feasible biotechnological and bioremediation strategies for serpentine soils and mine spoils. Electronic Journal of Biotechnology 2:20-34. 
Purcell, A. H., C. Friedrich, and V. H. Resh. 2002. An assessment of a small urban stream restoration project in northern California. Restoration Ecology 10:685-694.

R Development Core Team. 2008. R: a language and environment for statistical computing. R Foundation for Statistical Computing, Vienna, Austria.

Raikow, D. F., S. A. Grubbs, and K. W. Cummins. 1995. Debris dam dynamics and coarse particulate organic matter retention in an Appalachian Mountain stream. Journal of the North American Benthological Society 14:535-546.

Raisin, G. W., D. S. Mitchell, and R. L. Croome. 1997. The effectiveness of a small constructed wetland in ameliorating diffuse nutrient loadings from an Australian rural catchment. Ecological Engineering 9:19-35.

Ranken, R. B., W. K. Gram, D. K, Fantz, S. C. Richter, T. J. Miller, K. B. Ricke, B. Russell, and X. Wang. 2004. Effects of forest management on amphibians and reptiles in Missouri Ozark forests. Conservation Biology 18:174-188.

Rentch, J. S., J. T. Anderson, S. Lamont, J. Sencindiver, and R. Eli. 2008. Vegetation along hydrologic, edaphic, and geochemical gradients in a high-elevation poor fen in Canaan Valley, West Virginia. Wetlands Ecology and Management 16:237-253. 
Roberts, L. 1993. Wetlands trading is a loser's game, say ecologists. Science 260:18901892.

Robertson, A. L., and A. M. Milner. 1999. Meiobenthic arthropod communities in new streams in Glacier Bay National Park, Alaska. Hydrobiologia 397:197-209.

Rodrigue, J. A. 2001. Woody species diversity, forest and site productivity, stumpage value, and carbon sequestration of forests on mined lands reclaimed prior to the passage of the Surface Mining Control and Reclamation Act of 1977. Thesis. Virginia polytechnic Institute and State University, Blacksburg, VA.

Rosgen, David L. 2001. A practical method of computing streambank erosion rate, Seventh Federal Interagency Sediment Conference, Reno, Nevada, 24-29, March 2001. Reno, NV.

Saunders, D. L., J. J. Meeuwig, and A. C. J. Vincent. 2002. Freshwater protected areas: strategies for conservation. Conservation Biology 16:30-41.

Schuster, W. S., and R. J. Hutnik. 1987. Community development on 35-year-old planted minespoil banks in Pennsylvania. Reclamation, Revegetation, and Restoration 6:109-120. 
Shaffer, H. B., R. A. Alford, B. D. Woodward, S. J. Richards, R. G. Altig, and C. Gascon. 1994. Quantitative sampling of amphibian larvae. Pages 130-131 in W. R. Heyer, M. A. Donnelly, R. W. McDiarmid, L. C. Hayek, and M. S. Foster, editors. Measuring and monitoring biological diversity. Standard methods for amphibians. Smithsonian Institution, Washington, D.C.

Short, R. A., and P. E. Maslin. 1977. Processing of leaf litter by a stream detritivore: effect of nutrient availability to collectors. Ecology 58:935-938.

Simon, K. S., M. A. Simon, and, E. F. Benfield. 2009. Variation in ecosystem function in Appalachian stream along an acidity gradient. Ecological Applications 19:1147-1160.

Skousen, J. G., C. D. Johnson, and K. Garbutt. 1994. Natural revegetation of 15 abandoned mine land sites in West Virginia. Journal of Environmental Quality 23:12241230.

Skousen, J., P. Ziemkiewicz, and C. Venable. 2006. Tree recruitment and growth on 20year-old, unreclaimed surface mined lands in West Virginia. International Journal of Mining, Reclamation and Environment 20:142-154.

Sobolewski. A. 1999. A review of processes responsible for metal removal in wetlands treating contaminated mine drainage. International Journal of phytoremediation 1:19-51. 
Speaker, R., K. Moore, and S. Gregory. 1984. Analysis of the process of retention of organic matter in stream ecosystems. Verhandlung der Internationalen Vereinigung für Angewandte und Theoretische Limnologie 22:1835-1841.

Spencer, R. G. M., J. M. E. Ahad, A. Baker, G. L. Cowie, R. Ganeshram, R. C. UpstillGoddard, and G. Uher. 2007. The estuarine mixing behaviour of peatland derived dissolved organic carbon and its relationship to chromophoric dissolved organic matter in two North Sea estuaries (U.K.). Estuarine, Coastal and Shelf Science 74:131-144.

Spieles D. J., and W. J. Mitsch. 2000. Macroinvertebrate community structure in high and low nutrient constructed wetlands. Wetlands 20:716-729.

Stauffer, J. R., and C. P. Ferreri. 2002. Characterization of stream fish assembladges in selected regions of mountaintop removal/valley fill coal mining. Appendix D in Programmatic Environmental Impact Statement on Mountaintop Mining/Valley Fills in Appalachia. United States Environmental Protection Agency, Region 3, Philadelphia, PA.

Stevens, C. E., A. W. Diamons, and T. S. Gabor. 2002. Anuran call surveys on small wetlands in Prince Edward Island, Canada restored by dredging of sediments. Wetlands 22:90-99. 
Stocum, A. S. 1980. Natural vegetation and its relationship to the environment of selected abandoned coal surface mines in the Cumberland Mountains of Tennessee. Thesis. University of Tennessee, Knoxville, TN.

Stuart, S. N., J. S. Chanson, N. A. Cox, B. E. Young, A. S. L. Rodrigues, D. L. Fishman, and R. W. Waller. 2004. Status and trends of amphibian declines and extinctions worldwide. Science 306:1783-1786.

Swan, C. M. 2004. Leaf diversity alters litter breakdown in a Piedmont stream. Journal of the North American Benthological Society 23:15-28.

Tate, C. M., and J. L. Meyer. 1983. The influence of hydrologic conditions and successional state on dissolved organic carbon export from forested watersheds. Ecological Society of America 64:25-32.

Taylor, J., and B. A. Middleton. 2004. Comparison of litter decomposition in a natural versus coal-slurry pond reclaimed as a wetland. Land Degradation and Development 15:439-446.

Thompson, R. L., W. G. Vogel, and D. D. Taylor. 1984. Vegetation and flora of a coal surface-mined area in Laurel County, Kentucky. Castanea 49:111-126. 
Thompson, R. L., G. L. Wade, and R. A. Straw. 1996. Natural and planted flora of the Log Mountain surface mined demonstration area, Bell County Kentucky. Pages 484-503 in Proceedings of the 1996 Annual Meeting of the American Society for Surface Mining and Reclamation, W. L. Daniels, J. A. Burger, and C. E. Zipper, editors. Virginia Tech Research Division, Blacksburg, VA.

Tiwary, R. K. 2001. Environmental impact of coal mining on water regime and its management. Water, Air, and Soil Pollution 132:185-199.

Torbert, J. L., J. A. Burger, S. H. Schoenholz, and R. E. Kreh. 2000. Growth of three pine species after eleven years on reclaimed mine soils in Virginia. Northern Journal of Applied Forestry 17:95-99.

USACOE. 2007. Functional assessment approach for high gradient streams in West Virginia. United States Army Corps of Engineers, Huntington District, Huntington, WV.

USACOE and VADEQ. 2007. Unified stream methodology. United States Army Corps of Engineers, Norfolk District, Norfolk, VA, and Virginia Department of Environmental Quality, Richmond, VA.

USEPA. 2005. Mountaintop mining/ valley fill cumulative impact assessment. United States Environmental Protection Agency, Region 3, Philadelphia, PA. 
Vannote, R. L., G. W. Minshall, K. W. Cummins, J. R. Sedell, and C. E. Cushing. 1980. The river continuum concept. Canadian Journal of Fisheries and Aquatic Sciences 37:130-137.

Wallace, J. B., S. L. Eggert, J. L. Meyer, and J. R. Webster. 1997. Multiple trophic levels of a forest stream linked to terrestrial litter inputs. Science 277:102-104.

Webster, J. R., A. P. Covich, J. L. Tank, and T. V. Crockett. 1994. Retention of coarse organic particles in streams in the southern Appalachian Mountains. Journal of The North American Benthological Society 13:140-150.

Whiles, M. R., and J. B. Wallace. 1997. Leaf litter decomposition and macroinvertebrate communities in headwater streams draining pine and hardwood catchments. Hydrobiologia 353:107-119.

Whiting, G. J., and J. P. Chanton. 2001. Greenhouse carbon balance of wetlands: methane emission versus carbon sequestration. Tellus 53:521-528.

Wichard, W., P. T. P. Tsui, and H. Komnick. 1973. Effect of different salinities on the coniform chloride cells of mayfly larvae. Journal of Insect Physiology 19:1825-1835. 
Wieder, R. K., and G. E. Lang. 1984. Influence of wetlands and coal mining on stream water chemistry. Water, Air, and Soil Pollution 23:381-396.

Wiley, J. B., and E. D. Brogan. 2003. Comparison of peak discharges among sites with and without valley fills for the July 8-9, 2001, flood in the headwaters of Clear Fork, Coal River Basin, mountaintop coal-mining region, Southern West Virginia. Open-File Report 03-133. United States Geological Survey, Charleston, WV.

Wiley, J. B., F. D. Evaldi, J. H. Eyechaner, and D. B. Chambers. 2001. Reconnaissance of stream geomorphology, low streamflow, and stream temperature in the mountaintop coal-mining region, southern West Virginia. Water-Resources Investigations Report 014092. United States Geological Survey, Charleston, WV.

Winger, P. V., P. J. Lasier, and K. J. Bogenrieder. 2005. Combined use of rapid bioassessment protocols and sediment quality triad to assess stream quality. Environmental Monitoring and Assessment 100:267-295.

Winterbourn, M. J., J. S. Rounick, and B. Cowie. 1981. Are New Zealand stream ecosystems really different? New Zealand Journal of Marine and Freshwater Research 15:321-328. 
Wipfli, M. S. 2005. Trophic linkages between headwater forests and downstream fish habitats: implications for forest and fish management. Landscape and Urban Planning 72:201-213.

Wipfli, M. S., J. S. Richardson, and R. J. Naiman. 2007. Ecological linkages between headwaters and downstream ecosystems: transport of organic matter, invertebrates, and wood down headwater channels. Journal of the American Water Resouces Association 43:72-85.

WVDEP. 1996. An ecological assessment of the Cheat River watershed.

WVDEP/0502004-1996. West Virginia Division of Environmental Protection Charleston, WV.

WVDEP. 2007. Code of state rules. Title 47 Section 47-2-3. West Virginia Department of Environmental Protection, Charleston, WV.

Yavitt, J. B., T. J. Fahey, R. Long, and C. T. Driscoll. 2006. Solutes and soil in and around an in-stream wetland on the Hubbard Brook experimental forest, New Hampshire, U.S.A. Wetlands 26:376-384.

Young, R. G., and A. D. Huryn. 1999. Effects of land use on stream metabolism and organic matter turnover. Ecological Applications 9:1359-1376. 
Zedler, J. B. 2003. Wetlands at your service: reducing impacts of agriculture at the watershed scale. Frontiers in Ecology and the Environment 1:65-72.

Zedler, J. B. 2004. Compensating for wetland losses in the United States. Ibis 146: 92100. 
Tables

Table 1. Site name, site code, site type, approximate age, mean discharge, calculated drainage area (DA), and HUC 10 watershed (as defined by the Natural Resources Conservation Service), latitude and longitude in decimal degrees for reclaimed mine perimeter channels and reference streams. $\mathrm{P}=$ reclaimed mine perimeter channel. $\mathrm{R}=$ reference site na $=$ not applicable

\begin{tabular}{|c|c|c|c|c|c|c|c|c|}
\hline Site Names & $\begin{array}{l}\text { Site } \\
\text { Code }\end{array}$ & $\begin{array}{l}\text { Site } \\
\text { Type }\end{array}$ & $\begin{array}{c}\text { Approx. } \\
\text { Age } \\
\text { (years) }\end{array}$ & $\begin{array}{c}\text { Mean } \\
\text { Discharge } \\
\left(\mathrm{m}^{3} / \mathrm{s}\right)\end{array}$ & $\begin{array}{c}\text { Calculated } \\
\text { DA (ha) }\end{array}$ & (HUC 10) Watershed & $\begin{array}{l}\text { Latitude } \\
\text { (DD) }\end{array}$ & $\begin{array}{l}\text { Longitude } \\
\text { (DD) }\end{array}$ \\
\hline White Oak & P_WO & $\mathrm{P}$ & 3 & 0.01588 & 45 & Coal River & 38.04778 & -81.52139 \\
\hline Argus & P_AR & $\mathrm{P}$ & 5 & 0.00127 & 6 & East Fork Twelvepole & 37.98972 & -82.25222 \\
\hline Stanley Branch & P_ST & $\mathrm{P}$ & 10 & 0.01165 & 33 & Mud River & 38.08306 & -81.93472 \\
\hline Sugartree & P_SU & $\mathrm{P}$ & 10 & 0.01304 & 37 & Mud River & 38.09007 & -81.95751 \\
\hline Big Horse & P_BH & $\mathrm{P}$ & 20 & 0.00300 & 12 & Little Coal River & 38.08500 & -81.89750 \\
\hline Unnamed Tributary to Hell Creek & R_HC & $\mathrm{R}$ & na & 0.00048 & 7 & Pigeon Creek & 37.73044 & -82.23232 \\
\hline Unnamed Tributary to Lukey Fork & R_LF & $\mathrm{R}$ & na & 0.00280 & 10 & Mud River & 38.05944 & -81.95306 \\
\hline Unnamed Tributary to Mud Creek East & R_ME & $\mathrm{R}$ & na & 0.00107 & 5 & Mud River & 38.04647 & -81.91148 \\
\hline Unnamed Tributary to Mud Creek West & R_MW & $\mathrm{R}$ & na & 0.00287 & 11 & Mud River & 38.06105 & -81.94331 \\
\hline Unnamed Tributary to White Oak & R_WO & $\mathrm{R}$ & na & 0.00440 & 16 & Coal River & 38.05250 & -81.52278 \\
\hline
\end{tabular}


Table 2. Sampled parameters for reclaimed mine perimeter channels and reference sites with sampling dates.

\begin{tabular}{ll}
\hline \multicolumn{1}{c}{ Response Variables } & \multicolumn{1}{c}{ Sample Dates } \\
\hline Mean Daily Water Temp $\left({ }^{\circ} \mathrm{C}\right)$ & June 08 - June 09 \\
Mean Q $\left(\mathrm{m}^{3} / \mathrm{s}\right)$ & Feb 08, Mar 08, May, 08, June 08, July 08, Oct 08, Dec 08, Feb 09, May 09 \\
\hline Water Chemistry & Feb 08, Mar 08, June 08, Oct 08, Feb 09, May 09 \\
\hline Mean Alkalinity $(\mathrm{mg} / \mathrm{L})$ & Feb 08, Mar 08, June 08, Oct 08, Feb 09, May 09 \\
Mean Acidity $(\mathrm{mg} / \mathrm{L})$ & Feb 08, Mar 08, June 08, Oct 08, Feb 09, May 09 \\
\hline Seasonal Water Chemistry & \\
\hline Mean pH & Feb 08, Mar 08, May, 08, June 08, July 08, Oct 08, Dec 08, Feb 09, May 09 \\
Mean Cond $(\mu \mathrm{S} / \mathrm{cm})$ & Feb 08, Mar 08, May, 08, June 08, July 08, Oct 08, Dec 08, Feb 09, May 09 \\
Mean DO $(\mathrm{mg} / \mathrm{L})$ & Feb 08, Mar 08, May, 08, June 08, July 08, Oct 08, Dec 08, Feb 09, May 09 \\
Mean TDS $(\mathrm{mg} / \mathrm{L})$ & Feb 08, Mar 08, May, 08, June 08, July 08, Oct 08, Dec 08, Feb 09, May 09 \\
\hline Habitat Assessment & \\
\hline EPA RBP & March 08 \\
VA USM & June 08 \\
WV FCU & June 08 \\
BEHI & June 08 \\
ORAM & Oct 08 \\
\hline Vegetation & June 08 \\
\hline Macroinvertebrates & \\
\hline WVSCI Score & May 08 \\
Pct Chironomid & May 08 \\
Pct Tolerant & May 08 \\
Pct EPT & May 08 \\
\hline
\end{tabular}


Table 2 continued.

\begin{tabular}{ll}
\hline \multicolumn{1}{c}{ Response Variables } & \multicolumn{1}{c}{ Sample Dates } \\
\hline EPT Richness & May 08 \\
Total Invertebrate Richness & May 08 \\
Total Inverts & May 08 \\
Total Invert Biomass $\left(\mathrm{g} / \mathrm{m}^{2}\right)$ & May 08 \\
\hline Amphibians & \\
\hline Amph Species Richness & Mar 08, May 08, June 08, July 08 \\
Larval Amph Species Richness & Mar 08, May 08, June 08, July 08 \\
Adult Amph Species Richness & Mar 08, May 08, June 08, July 08 \\
Total No Amph & Mar 08, May 08, June 08, July 08 \\
Total No Adult Amph & Mar 08, May 08, June 08, July 08 \\
Total No Larval Amph & Mar 08, May 08, June 08, July 08 \\
Mean Larval Amph Biomass $\left(100 \mathrm{~g} / \mathrm{m}^{2}\right)$ & Mar 08, May 08, June 08, July 08 \\
Mean Amph Density (ind/m²) & Mar 08, May 08, June 08, July 08 \\
Pct Grassland Amph & Mar 08, May 08, June 08, July 08 \\
Grassland Amph Species & Mar 08, May 08, June 08, July 08 \\
Pct Forest Amph & Mar 08, May 08, June 08, July 08 \\
Pct Lotic Amph & Mar 08, May 08, June 08, July 08 \\
Pct Lentic Amph & Mar 08, May 08, June 08, July 08 \\
Lentic Amph Species & Mar 08, May 08, June 08, July 08 \\
\hline OM Processing & \\
\hline Decomp Rate & May 08, June 08, July 08, Oct 08, Feb 09 \\
\hline OM Retention & \\
\hline Mean Leaf Distance (m) & March 08, June 08, Oct, 08, Feb 09 \\
Mean Cumm Stick Distance (m) & March 08, May 08, June 08, Oct 08 \\
Retention Rate & derived \\
Anl Mean DOC (mg/L) & May 08, Jun 08, Oct 08, Feb 09 \\
Processing Power * 100 & derived \\
\hline & \\
\hline
\end{tabular}


Table 3. Habitat assessment scores for reclaimed mine perimeter channels and reference streams. RBP= Rapid Bioassessment Protocol, USM= Unified Stream Method, FCU= Functional Channel Unit Assessment, BEHI= Bank Erosion Hazard Index, and ORAM = Ohio Rapid Assessment Method. Mean and standard deviation by site type are given in the last two rows. Perimeter channel sites are listed in increasing age since reclamation. Statistical significance is indicated by $*=<0.05$.

\begin{tabular}{lcccccc}
\hline Site Code & $\begin{array}{c}\text { EPA } \\
\text { RBP* }\end{array}$ & $\begin{array}{c}\text { VA } \\
\text { USM* }\end{array}$ & $\begin{array}{c}\text { WV } \\
\text { FCU* }\end{array}$ & BEHI* & $\begin{array}{c}\text { BEHI } \\
\text { Qualifier }\end{array}$ & $\begin{array}{c}\text { ORAM } \\
\text { Score* }\end{array}$ \\
\hline P_WO & 55 & 5 & 3 & 36 & High & 18 \\
P_AR & 88 & 3 & 3 & 12 & Low & 21 \\
P_ST & 79 & 4 & 2 & 24 & Moderate & 48 \\
P_SU & 85 & 4 & 4 & 24 & Moderate & 44 \\
P_BH & 84 & 4 & 3 & 20 & Low & 43 \\
R_HC & 172 & 7 & 9 & 46 & Very High & 50 \\
R_LF & 132 & 6 & 8 & 39 & High & 68 \\
R_ME & 136 & 6 & 9 & 42 & Very High & 71 \\
R_MW & 133 & 6 & 10 & 36 & High & 58 \\
R_WO & 175 & 7 & 9 & 31 & High & 59 \\
\hline Perimeter & $78 \pm 13$ & $4 \pm 1$ & $3 \pm 1$ & $23 \pm 9$ & - & $35 \pm 14$ \\
Reference & $150 \pm 22$ & $6 \pm 0$ & $9 \pm 1$ & $39 \pm 6$ & - & $61 \pm 8$ \\
\hline
\end{tabular}


Table 4. Mean and standard error for site types. Water chemistry means were calculated using $1 / 2$ the method detection limit (MDL) for values at MDL. T test statistics for means $*=<0.05, * *=<0.005, * * *=<0.001$.

\begin{tabular}{|c|c|c|c|}
\hline Response Variables & Perimeter Mean & Reference Mean & $\begin{array}{l}\text { T test } \mathrm{P} \text { vs } \mathrm{R} \\
(\mathrm{df}=8)\end{array}$ \\
\hline \multicolumn{4}{|l|}{ Temperature } \\
\hline Max Daily Temp $\left({ }^{\circ} \mathrm{C}\right)$ & $30.7(3.2)$ & $31.9(2.4)$ & -0.2922 \\
\hline Min Daily Temp $\left({ }^{\circ} \mathrm{C}\right)$ & $0.15(0.08)$ & $0.00(0.00)$ & 2.2826 \\
\hline Mean Daily Temp $\left({ }^{\circ} \mathrm{C}\right)$ & $10.5(0.2)$ & $9.6(0.7)$ & 1.1182 \\
\hline CV for Mean Daily Temp & $63.6(3.5)$ & $58.9(4.8)$ & 0.7953 \\
\hline \multicolumn{4}{|l|}{ Discharge } \\
\hline Mean Spring Q (m³ $/ \mathrm{s})$ & $0.011(0.004)$ & $0.001(0.001)$ & 2.7123* \\
\hline Mean Sum Q (m³/s) & $0.003(0.003)$ & $0.000(0.000)$ & 1.0716 \\
\hline Mean Aut Q (ms $/ \mathrm{s})$ & $0.006(0.004)$ & $0.001(0.001)$ & 1.1153 \\
\hline Mean Winter Q (m $/ \mathrm{s})$ & $0.017(0.005)$ & $0.006(0.002)$ & 1.8001 \\
\hline Mean Q $\left(\mathrm{m}^{3} / \mathrm{s}\right)$ & $0.009(0.003)$ & $0.002(0.001)$ & 2.1576 \\
\hline \multicolumn{4}{|l|}{ Water Chemistry } \\
\hline Mean Alkalinity (mg/L) & $138(13)$ & $5(1)$ & $12.8148^{* * *}$ \\
\hline Mean Acidity (mg/L) & $0(0)$ & $13(5)$ & $-4.8816^{* *}$ \\
\hline Mean Al (mg/L) & $0.1(0.0)$ & $0.5(0.5)$ & -0.867 \\
\hline Mean Ca (mg/L) & $163(31)$ & $21(15)$ & $4.9602 * *$ \\
\hline Mean Fe (mg/L) & $0.10(0.04)$ & $0.06(0.00)$ & 1.0342 \\
\hline Mean Mg (mg/L) & $154(34)$ & $9(4)$ & $6.1238 * * *$ \\
\hline Mean Mn (mg/L) & $0.3(0.2)$ & $0.4(0.3)$ & 0.2048 \\
\hline Mean $\mathrm{SO}_{4}(\mathrm{mg} / \mathrm{L})$ & 1008 (196) & $32(20)$ & $7.7072^{* * *}$ \\
\hline Mean Cl (mg/L) & $13.8(9.7)$ & $11.4(10.2)$ & 0.4478 \\
\hline Mean $\mathrm{NO}_{2}(\mathrm{mg} / \mathrm{L})$ & $0.04(0.03)$ & $3.10(3.08)$ & -0.9352 \\
\hline Mean $\mathrm{NO}_{3}(\mathrm{mg} / \mathrm{L})$ & $11.0(10.4)$ & $0.8(0.2)$ & 0.8778 \\
\hline Mean TP (mg/L) & $0.08(0.04)$ & $0.05(0.01)$ & 0.6656 \\
\hline Mean $\mathrm{NH}_{3}(\mathrm{mg} / \mathrm{L})$ & $0.007(0.003)$ & $0.013(0.002)$ & -1.9669 \\
\hline Mean Ba (mg/L) & $0.016(0.002)$ & $0.093(0.060)$ & -1.7213 \\
\hline
\end{tabular}


Table 4 continued.

\begin{tabular}{lccc}
\hline \multicolumn{1}{c}{ Response Variables } & Perimeter Mean & Reference Mean & $\begin{array}{c}\text { T test P vs R } \\
(\mathrm{df}=8)\end{array}$ \\
\hline Mean Cd $(\mathrm{mg} / \mathrm{L})$ & $0.007(0.000)$ & $0.008(0.000)$ & -0.6325 \\
Mean Co $(\mathrm{mg} / \mathrm{L})$ & $0.011(0.002)$ & $0.009(0.001)$ & 1.0018 \\
Mean Cr $(\mathrm{mg} / \mathrm{L})$ & $0.006(0.000)$ & $0.009(0.001)$ & $-2.5058^{*}$ \\
Mean Cu $(\mathrm{mg} / \mathrm{L})$ & $0.008(0.000)$ & $0.008(0.000)$ & $\mathrm{NA}$ \\
Mean Na $(\mathrm{mg} / \mathrm{L})$ & $13.2(6.3)$ & $23.7(22.2)$ & 0.0937 \\
Mean Ni $(\mathrm{mg} / \mathrm{L})$ & $0.034(0.019)$ & $0.024(0.011)$ & 0.4772 \\
Mean Zn $(\mathrm{mg} / \mathrm{L})$ & $0.020(0.008)$ & $0.042(0.031)$ & -0.4481 \\
Mean Se $(\mathrm{mg} / \mathrm{L})$ & $0.024(0.002)$ & $0.030(0.005)$ & -1.019 \\
Mean Spring pH & $7.3(0.1)$ & $6.9(0.5)$ & 0.7736 \\
Mean Summer pH & $7.2(0.2)$ & $5.7(0.3)$ & $4.0200^{* *}$ \\
Mean Autumn pH & $7.7(0.1)$ & $7.1(0.5)$ & 1.4153 \\
Mean Winter pH & $7.4(0.1)$ & $7.3(0.5)$ & 0.1104 \\
Mean pH & $7.4(0.1)$ & $6.7(0.4)$ & 1.5589 \\
Mean Spr Cond $(\mu \mathrm{S} / \mathrm{cm})$ & $2310(495)$ & $602(445)$ & $2.5668^{*}$ \\
Mean Sum Cond $(\mu \mathrm{S} / \mathrm{cm})$ & $2255(488)$ & $642(501)$ & 2.3055 \\
Mean Aut Cond $(\mu \mathrm{S} / \mathrm{cm})$ & $2147(448)$ & $133(75)$ & $4.5142^{* *}$ \\
Mean Win Cond $(\mu \mathrm{S} / \mathrm{cm})$ & $2077(395)$ & $147(64)$ & $4.8184^{* *}$ \\
Mean Cond $(\mu \mathrm{s} / \mathrm{cm})$ & $2197(414)$ & $461(326)$ & $3.2938^{*}$ \\
Mean Spring DO $(\mathrm{mg} / \mathrm{L})$ & $6.8(0.6)$ & $7.7(1.0)$ & -0.7069 \\
Mean Sum DO $(\mathrm{mg} / \mathrm{L})$ & $9.1(1.0)$ & $10.4(2.9)$ & -0.2203 \\
Mean Aut DO $(\mathrm{mg} / \mathrm{L})$ & $9.5(1.3)$ & $10.2(1.3)$ & 0.5170 \\
Mean Winter DO $(\mathrm{mg} / \mathrm{L})$ & $9.3(1.1)$ & $11.7(0.7)$ & -1.7323 \\
Mean DO $(\mathrm{mg} / \mathrm{L})$ & $8.7(0.5)$ & $9.9(1.0)$ & -1.1108 \\
Spring TDS $(\mathrm{mg} / \mathrm{L})$ & $1366(294)$ & $76(28)$ & $5.9862^{* * *}$ \\
Summer TDS $(\mathrm{mg} / \mathrm{L})$ & $1818(455)$ & $157(95)$ & $4.5826^{* *}$ \\
Autumn TDS $(\mathrm{mg} / \mathrm{L})$ & - & - & - \\
\hline & & &
\end{tabular}


Table 4 continued.

\begin{tabular}{lccc}
\hline \multicolumn{1}{c}{ Response Variables } & Perimeter Mean & Reference Mean & $\begin{array}{c}\text { T test P vs R } \\
(\mathrm{df}=8)\end{array}$ \\
\hline Winter TDS (mg/L) & $27.0(5.0)$ & $3.7(0.7)$ & $6.8737^{* * *}$ \\
Mean TDS (mg/L) & $25.2(3.0)$ & $2.7(0.4)$ & $6.8135^{* * *}$ \\
Spring TC (mg/L) & $3.3(0.6)$ & - & $6.1920^{* * *}$ \\
Summer TC (mg/L) & $3.4(0.6)$ & $1.4(0.1)$ & $10.3569^{* * *}$ \\
Autumn TC (mg/L) & $15.6(2.0)$ & $2.6(0.3)$ & - \\
Winter TC (mg/L) & $18.5(2.1)$ & $2.6(0.3)$ & $3.4641^{*}$ \\
Mean TC (mg/L) & $27.0(5.0)$ & $3.7(0.7)$ & $9.6959^{* * *}$ \\
\hline Habitat Assessment & & & \\
\hline EPA RBP & $78(6)$ & $150(10)$ & $6.2240^{* * *}$ \\
VA USM & $4(0)$ & $6(0)$ & $-5.3492^{* * *}$ \\
WV FCU & $3(0)$ & $9(0)$ & $-14.6677^{* * *}$ \\
BEHI & $23(4)$ & $39(3)$ & $-3.2882^{*}$ \\
ORAM & $35(6)$ & $61(4)$ & $-3.5899^{*}$ \\
\hline Vegetation & & \\
\hline Pct Bare Ground & $3(2)$ & $29(8)$ & $-3.2254^{*}$ \\
Pct Cattail & $21(7)$ & $0(0)$ & $3.0614^{*}$ \\
Pct Fern & $0(0)$ & $11(2)$ & $-5.1953^{* * *}$ \\
Pct Forb & $22(8)$ & $22(5)$ & 0.0269 \\
Pct Grass & $22(4)$ & $2(1)$ & $5.5151^{* * *}$ \\
Pct Open Water & $13(6)$ & $0(0)$ & 2.0459 \\
Pct Tree & $1(1)$ & $16(3)$ & $-4.1779^{* *}$ \\
Pct Vine & $2(1)$ & $8(2)$ & $-3.1965^{*}$ \\
Species per km ${ }^{2}$ & $0.1(0.1)$ & $2.5(0.3)$ & $-9.0068^{* * *}$ \\
Trees per km ${ }^{2}$ & $0.3(0.3)$ & $9.2(2.2)$ & $-6.3294^{* * *}$ \\
Pct Canopy Cover & $4(4)$ & $91(1)$ & $-26.1052^{* * *}$ \\
\hline
\end{tabular}


Table 4 continued.

\begin{tabular}{lccc}
\hline \multicolumn{1}{c}{ Response Variables } & Perimeter Mean & Reference Mean & $\begin{array}{c}\text { T test P vs R } \\
\text { (df }=8)\end{array}$ \\
\hline Macroinvertebrates & & & \\
\hline WVSCI Score & $48(5)$ & $68(8)$ & -2.0154 \\
Pct Chironomid & $58(16)$ & $32(11)$ & 1.4183 \\
Pct Tolerant & $70(15)$ & $42(13)$ & 1.5593 \\
Pct EPT & $5(4)$ & $48(16)$ & $-2.4847^{*}$ \\
EPT Richness & $1(0)$ & $4(1)$ & $-2.6662^{*}$ \\
Total Richness & $8(2)$ & $7(1)$ & 0.5282 \\
Total Inverts & $763(273)$ & $213(87)$ & 1.8116 \\
Pct 2 Dominant Sp & $78(10)$ & $66(6)$ & 1.2398 \\
Total Biomass (g/m $\left.{ }^{2}\right)$ & $31.8(18.9)$ & $34.5(14.9)$ & -0.0852 \\
Pct Collector- Gatherer & $74(12)$ & $57(9)$ & 1.3313 \\
Pct Filterer & $2(2)$ & $0(0)$ & 1.3208 \\
Pct Scraper & $6(4)$ & $3(3)$ & 0.5337 \\
Pct Shredder & $2(2)$ & $27(11)$ & -2.1756 \\
Pct Predator & $8(3)$ & $5(3)$ & 0.8231 \\
Pct Omnivore & $8(5)$ & $3(3)$ & 0.7782 \\
Pct Unknown & $0(0)$ & $5(2)$ & $-2.5767 *$ \\
\hline Amphibians & & & \\
\hline Total No Amph Sp & $3(1)$ & $3(0)$ & -0.6040 \\
Total Larval Amph Sp & $2(1)$ & $2(0)$ & 0.1989 \\
Total Adult Amph Sp & $1(0)$ & $2(0)$ & -2.1909 \\
Total No Amph & $24(14)$ & $36(14)$ & -0.6352 \\
Mean No Amph & $6(4)$ & $9(4)$ & -0.6352 \\
Total No Adult Amph & $5(3)$ & $28(13)$ & -1.9154 \\
\hline
\end{tabular}


Table 4 continued.

\begin{tabular}{lccc}
\hline \multicolumn{1}{c}{ Response Variables } & Perimeter Mean & Reference Mean & $\begin{array}{c}\text { T test P vs R } \\
(\mathrm{df}=8)\end{array}$ \\
\hline Total No Adult Amph & $5(3)$ & $28(13)$ & -1.9154 \\
Mean No Adult Amph & $1(1)$ & $7(3)$ & -2.0744 \\
Total No Larval Amph & $19(11)$ & $8(3)$ & 0.7208 \\
Mean No Larval Amph & $5(3)$ & $2(1)$ & 2.0714 \\
Total Larval Amph Biomass $\left(100 \mathrm{~g} / \mathrm{m}^{2}\right)$ & $0.053(0.041)$ & $0.002(0.001)$ & 1.2522 \\
Mean Larval Amph Biomass $\left(100 \mathrm{~g} / \mathrm{m}^{2}\right)$ & $0.0133(0.0103)$ & $0.0005(0.0002)$ & 1.2522 \\
Mean Amph Density (ind/m $\left.{ }^{2}\right)$ & $1.2(0.7)$ & $1.8(0.7)$ & -0.6386 \\
Pct Grassland Amph & $58(18)$ & $0(0)$ & $2.7647^{*}$ \\
Pct Forest Amph & $95(5)$ & $100(0)$ & -1.0000 \\
Pct Lotic Amph & $5(3)$ & $86(13)$ & $-5.1102^{* * *}$ \\
Pct Lentic Amph & $89(8)$ & $54(8)$ & $3.0617^{*}$ \\
\hline Decomposition & & & \\
\hline Decomp Rate & $0.0021(0.0002)$ & $0.0035(0.0009)$ & -1.5186 \\
Mean Total Wt (g) (325 d) & $6.7(0.9)$ & $5.3(1.6)$ & 0.7314 \\
Mean \% Organic (325 d) & $85(7)$ & $78(6)$ & 0.5694 \\
Mean Organic Mass (g) (325 d) & $5.3(0.1)$ & $3.8(0.9)$ & 1.7560 \\
Mean \% Org Mass Lost (325 d) & $47(1)$ & $62(9)$ & -1.7389 \\
\hline OM Retention & & & \\
\hline Mean Leaf Distance (m) & $0.52(0.52)$ & $0.42(0.15)$ & -0.6724 \\
Mean Cum Stick Distance (m) & $7.44(7.44)$ & $26.89(4.81)$ & $-2.9434^{*}$ \\
Mean Cum Stick Dist/ Day & $0.04(0.04)$ & $0.14(0.02)$ & $-2.9434^{*}$ \\
Retention Rate & $-0.064(0.014)$ & $-0.020(0.005)$ & 2.0714 \\
Pct Sticks Retained & $87(13)$ & $59(9)$ & $2.5499^{*}$ \\
No Sticks Exiting Reach & $21(5)$ & $-3.7641^{*}$ \\
\hline
\end{tabular}


Table 4 continued.

\begin{tabular}{lccc}
\hline \multicolumn{1}{c}{ Response Variables } & Perimeter Mean & Reference Mean & $\begin{array}{c}\text { T test P vs R } \\
(\mathrm{df}=8)\end{array}$ \\
\hline Dissolved Organic Carbon & & & \\
\hline Spring DOC $(\mathrm{mg} / \mathrm{L})$ & $4.9(1.7)$ & $2.5(0.6)$ & 1.0170 \\
Summer DOC $(\mathrm{mg} / \mathrm{L})$ & $2.8(1.2)$ & $1.0(0.2)$ & 1.6977 \\
Autumn DOC $(\mathrm{mg} / \mathrm{L})$ & $4.2(1.4)$ & - & - \\
Winter DOC $(\mathrm{mg} / \mathrm{L})$ & $2.1(0.4)$ & $1.0(0.1)$ & $3.0508^{*}$ \\
Mean DOC $(\mathrm{mg} / \mathrm{L})$ & $3.5(0.9)$ & $1.5(0.3)$ & 2.0183 \\
\hline Processing Power & \multicolumn{3}{l}{} \\
\hline Processing Power * 100 & $0.013(0.003)$ & $0.007(0.002)$ & 1.6318 \\
\hline
\end{tabular}


Table 5. Percentage of vegetation from vegetation survey for reference sites and reclaimed mine perimeter channels. Mean and standard deviation by site type are given in the last two rows. Perimeter channel sites are listed in increasing age since reclamation. Statistical significance is indicated by $*=<0.05$.

\begin{tabular}{|c|c|c|c|c|c|c|c|c|}
\hline Site Code & $\begin{array}{c}\text { Bare } \\
\text { Ground* }\end{array}$ & Cattail* & Fern* & Forb & Grass* & $\begin{array}{l}\text { Open } \\
\text { Water }\end{array}$ & Tree* & Vine* \\
\hline P_WO & 11 & 3 & 0 & 13 & 19 & 38 & 5 & 6 \\
\hline P_AR & 0 & 7 & 0 & 51 & 30 & 4 & 0 & 0 \\
\hline P_ST & 0 & 34 & 0 & 8 & 31 & 8 & 0 & 3 \\
\hline P_SU & 2 & 24 & 0 & 27 & 21 & 8 & 0 & 0 \\
\hline P_BH & 3 & 34 & 2 & 10 & 11 & 7 & 2 & 0 \\
\hline R_HC & 23 & 0 & 16 & 31 & 2 & 0 & 16 & 5 \\
\hline R_LF & 40 & 0 & 8 & 11 & 2 & 0 & 11 & 11 \\
\hline R_ME & 51 & 0 & 7 & 7 & 0 & 0 & 9 & 9 \\
\hline R_MW & 26 & 0 & 8 & 29 & 5 & 0 & 14 & 5 \\
\hline R_WO & 6 & 0 & 15 & 31 & 0 & 0 & 28 & 12 \\
\hline Perimeter & $3 \pm 5$ & $21 \pm 15$ & $0 \pm 1$ & $22 \pm 18$ & $22 \pm 8$ & $13 \pm 14$ & $1 \pm 2$ & $2 \pm 3$ \\
\hline Reference & $29 \pm 17$ & $0 \pm 0$ & $11 \pm 5$ & $22 \pm 12$ & $2 \pm 2$ & $0 \pm 0$ & $16 \pm 7$ & $8 \pm 4$ \\
\hline
\end{tabular}


Table 6. Percent canopy cover and tree count data for reference sites and reclaimed mine perimeter channels. Mean and standard deviation by site type are given in the last two rows. Perimeter channel sites are listed in increasing age since reclamation. Statistical significance is indicated by $*=<0.05$.

\begin{tabular}{lccc}
\hline Site Code & $\begin{array}{c}\text { Species* } \\
\text { per } \\
1000 \mathrm{~m}^{2}\end{array}$ & $\begin{array}{c}\text { Trees* } \\
\text { per } \\
1000 \mathrm{~m}^{2}\end{array}$ & $\begin{array}{c}\text { Pct* } \\
\text { Canopy } \\
\text { Cover }\end{array}$ \\
\hline P_WO & 0.0 & 0.0 & 0 \\
P_AR & 0.0 & 0.0 & 1 \\
P_ST & 0.0 & 0.0 & 20 \\
P_SU & 0.0 & 0.0 & 0 \\
P_BH & 0.4 & 1.3 & 1 \\
R_HC & 2.1 & 3.8 & 89 \\
R_LF & 1.7 & 9.2 & 93 \\
R_ME & 2.9 & 10.4 & 92 \\
R_MW & 2.5 & 5.8 & 92 \\
R_WO & 3.3 & 16.7 & 90 \\
\hline Perimeter & $0.1 \pm 0.2$ & $0.3 \pm 0.6$ & $4 \pm 9$ \\
Reference & $2.5 \pm 0.7$ & $9.2 \pm 5.0$ & $91 \pm 2$ \\
\hline
\end{tabular}


Table 7. Repeated measures ANOVA analysis of seasonal parameters for reclaimed mine perimeter channels and reference streams. Statistical significance is indicated by *= $<0.05, * *=<0.005, * * *=<0.001$.

\begin{tabular}{lccc}
\hline \multicolumn{1}{c}{ Parameter } & $\begin{array}{c}\text { Type } \\
\mathrm{df}=1\end{array}$ & $\begin{array}{c}\text { Season } \\
\mathrm{df}=3\end{array}$ & $\begin{array}{c}\text { Type:Season } \\
\mathrm{df}=3\end{array}$ \\
\hline $\mathrm{pH}$ & 4.1082 & 1.2056 & 1.4659 \\
Temp $\left({ }^{\circ} \mathrm{C}\right)$ & $6.1466^{*}$ & $24.2531^{* * *}$ & $4.1556^{*}$ \\
Cond $(\mu \mathrm{S} / \mathrm{cm})$ & $14.486^{* *}$ & 1.1711 & 0.3070 \\
DO $(\mathrm{mg} / \mathrm{L})$ & 0.0646 & $19.6173^{* * *}$ & 0.3648 \\
$\mathrm{TDS}(\mathrm{mg} / \mathrm{L})$ & $24.343^{* *}$ & 1.5243 & 0.7794 \\
$\mathrm{Q}\left(\mathrm{m}^{3} / \mathrm{s}\right)$ & 5.0276 & $12.071^{* * *}$ & 1.0351 \\
DOC $(\mathrm{mg} / \mathrm{L})$ & 3.0713 & $5.4466^{*}$ & 0.0508 \\
\hline
\end{tabular}


Table 8. Temperature data $\left({ }^{\circ} \mathrm{C}\right)$ for reference sites and reclaimed mine perimeter channels for periods when streams contained water. Mean and standard deviation by site type are given in the last two rows. Perimeter channel sites are listed in increasing age since reclamation. No data were recovered from $\mathrm{P} \_$WO. Statistical significance is indicated by $*=<0.05, * *=<0.005, * * *=<0.001$.

\begin{tabular}{lccccc}
\hline Site Code & $\begin{array}{c}\text { Max Daily } \\
\text { Temp }\end{array}$ & $\begin{array}{c}\text { Min Daily } \\
\text { Temp }\end{array}$ & $\begin{array}{c}\text { Mean Daily } \\
\text { Temp }\end{array}$ & $\begin{array}{c}\text { CV for Mean } \\
\text { Daily Temp }\end{array}$ & $\begin{array}{c}\text { Mean Daily } \\
\text { Temp Range }\end{array}$ \\
\hline P_WO & - & - & - & - & - \\
P_AR & 22.08 & 0.41 & 9.82 & 54.51 & $1.54 \pm 1.27$ \\
P_ST & 26.45 & 0.14 & 10.89 & 63.20 & $3.85 \pm 2.70$ \\
P_SU & 40.57 & 0.00 & 10.93 & 63.96 & $4.45 \pm 2.48$ \\
P_BH & 34.57 & 0.00 & 10.10 & 75.97 & $6.03 \pm 4.66$ \\
R_HC & 38.90 & 0.00 & 12.51 & 42.44 & $4.89 \pm 6.28$ \\
R_LF & 31.38 & 0.00 & 9.01 & 69.39 & $5.21 \pm 4.18$ \\
R_ME & 23.86 & 0.00 & 9.11 & 54.57 & $3.13 \pm 2.23$ \\
R_MW & 34.07 & 0.00 & 8.26 & 62.55 & $4.84 \pm 4.80$ \\
R_WO & 31.05 & 0.00 & 9.05 & 65.66 & $5.96 \pm 4.01$ \\
\hline Perimeter & $30.92 \pm 8.26$ & $0.14 \pm 0.19$ & $10.44 \pm 0.56$ & $64.41 \pm 8.82$ & - \\
Reference & $31.85 \pm 5.46$ & $0.00 \pm 0.00$ & $9.59 \pm 1.67$ & $58.92 \pm 10.71$ & - \\
\hline
\end{tabular}


Table 9. Amphibian abundance survey totals, for four sample periods, observed on reclaimed mine perimeter channels and reference sites. Frog and salamander species’ preference for grassland or forest was based on information from Green and Pauley (1987). Mean and standard deviation by site type are given in the last two rows. Perimeter channel sites are listed in increasing age since reclamation. Statistical significance is indicated by $*=<0.05$.

\begin{tabular}{|c|c|c|c|c|c|c|c|c|c|c|}
\hline Site Code & $\begin{array}{c}\text { Total } \\
\text { Larva* }\end{array}$ & $\begin{array}{c}\text { Larval } \\
\text { Species* }\end{array}$ & $\begin{array}{c}\text { Total } \\
\text { Adults }\end{array}$ & $\begin{array}{c}\text { Adult } \\
\text { Species }\end{array}$ & $\begin{array}{c}\text { Total } \\
\text { Individuals* }\end{array}$ & $\begin{array}{c}\text { Total } \\
\text { Species* }\end{array}$ & $\begin{array}{l}\text { Pct Grassland } \\
\text { Amphibians* }\end{array}$ & $\begin{array}{c}\text { Pct Forest } \\
\text { Amphibians* }\end{array}$ & $\begin{array}{c}\text { Pct Lotic } \\
\text { Amphibians* }\end{array}$ & $\begin{array}{c}\text { Pct Lentic } \\
\text { Amphibians* }\end{array}$ \\
\hline P_WO & 0 & 0 & 6 & 2 & 6 & 2 & 100 & 100 & 17 & 100 \\
\hline P_AR & 63 & 5 & 17 & 2 & 80 & 5 & 89 & 100 & 0 & 81 \\
\hline P_ST & 9 & 1 & 3 & 1 & 12 & 1 & 25 & 100 & 8 & 100 \\
\hline P_SU & 12 & 4 & 1 & 1 & 13 & 4 & 69 & 77 & 0 & 62 \\
\hline P_BH & 12 & 2 & 0 & 0 & 12 & 2 & 8 & 100 & 0 & 100 \\
\hline R_HC & 3 & 1 & 8 & 2 & 11 & 2 & 0 & 100 & 100 & 55 \\
\hline R_LF & 8 & 2 & 45 & 4 & 53 & 5 & 0 & 100 & 98 & 57 \\
\hline R_ME & 13 & 2 & 69 & 2 & 82 & 3 & 0 & 100 & 100 & 44 \\
\hline R_MW & 14 & 2 & 15 & 2 & 29 & 3 & 0 & 100 & 100 & 83 \\
\hline R_WO & 1 & 1 & 2 & 2 & 3 & 3 & 0 & 100 & 33 & 33 \\
\hline Perimeter & $19 \pm 25$ & $2 \pm 2$ & $5 \pm 7$ & $1 \pm 1$ & $25 \pm 31$ & $3 \pm 2$ & $58 \pm 40$ & $95 \pm 10$ & $5 \pm 7$ & $89 \pm 17$ \\
\hline Reference & $8 \pm 6$ & $2 \pm 1$ & $28 \pm 28$ & $2 \pm 1$ & $36 \pm 32$ & $3 \pm 1$ & $0 \pm 0$ & $100 \pm 0$ & $86 \pm 30$ & $54 \pm 18$ \\
\hline
\end{tabular}


Table 10. Larval amphibian biomass $\left(\mathrm{g} / 100 \mathrm{~m}^{2}\right)$ for four sampling occasions observed on reclaimed mine perimeter channels and in reference sites. Mean and standard deviation by site type are given in the last two rows. Perimeter channel sites are listed in increasing age since reclamation.

\begin{tabular}{lcccccc}
\hline Site Code & March & May & June & July & Total & Mean \\
\hline P_WO & 0.00 & 0.00 & 0.00 & 0.00 & 0.00 & 0.00 \\
P_AR & 6.91 & 2.91 & 8.22 & 3.37 & 21.41 & 5.35 \\
P_ST & 0.00 & 0.06 & 0.00 & 0.00 & 0.06 & 0.01 \\
P_SU & 0.00 & 0.01 & 0.10 & 0.09 & 0.20 & 0.05 \\
P_BH & 0.00 & 4.87 & 0.11 & 0.00 & 4.99 & 1.25 \\
R_HC & 0.00 & 0.06 & 0.00 & 0.00 & 0.06 & 0.02 \\
R_LF & 0.05 & 0.14 & 0.02 & 0.00 & 0.21 & 0.05 \\
R_ME & 0.06 & 0.10 & 0.08 & 0.00 & 0.23 & 0.06 \\
R_MW & 0.08 & 0.20 & 0.02 & 0.11 & 0.41 & 0.10 \\
R_WO & 0.00 & 0.00 & 0.05 & 0.00 & 0.05 & 0.01 \\
\hline Perimeter & $1.38 \pm 3.09$ & $1.57 \pm 2.23$ & $1.69 \pm 3.65$ & $0.69 \pm 1.50$ & $5.33 \pm 9.24$ & $1.33 \pm 2.31$ \\
Reference & $0.04 \pm 0.04$ & $0.10 \pm 0.08$ & $0.03 \pm 0.03$ & $0.02 \pm 0.05$ & $0.19 \pm 0.14$ & $0.05 \pm 0.04$ \\
\hline
\end{tabular}


Table 11. ANCOVA analysis of the effects of site type, conductivity, and their interaction on various ecological measures in reclaimed mine perimeter channels and reference sites. Degrees of freedom $=7$. Statistical significance is indicated by $*=<0.05$, $* *=<0.005$, $* * *=<0.001$.

\begin{tabular}{|c|c|c|c|}
\hline Parameters & Type & Cond & $\begin{array}{l}\text { Type } \mathrm{x} \\
\text { Cond }\end{array}$ \\
\hline Decomp Rate & -0.085 & -1.020 & $3.417^{*}$ \\
\hline Mean Total Wt (g) (325 d) & $3.394 *$ & $4.829 * *$ & -1.895 \\
\hline Mean \% Organic (325 d) & -2.162 & -1.972 & $5.035 * *$ \\
\hline Mean Organic Mass (g) (325 d) & 0.615 & 1.837 & 0.744 \\
\hline Mean \% Org Mass Lost (325 d) & -0.854 & -0.854 & $4.168^{* *}$ \\
\hline WVSCI Score & -0.900 & $-2.673^{*}$ & $5.089 * *$ \\
\hline Pct Chironomid & 0.214 & 1.123 & 0.030 \\
\hline Pct Tolerant & 0.428 & 1.518 & -0.120 \\
\hline Pct EPT & -0.440 & $-2.420 *$ & $2.463^{*}$ \\
\hline EPT Richness & -0.877 & $-3.551 * *$ & $3.820 * *$ \\
\hline Total Richness & -1.789 & 0.133 & $3.318^{*}$ \\
\hline Total Inverts & -1.185 & -0.520 & 1.759 \\
\hline Pct 2 Dominant Sp & 0.241 & 1.035 & 1.056 \\
\hline Total Biomass $\left(\mathrm{g} / \mathrm{m}^{2}\right)$ & -0.756 & -0.935 & 1.682 \\
\hline Pct Collector- Gatherer & 0.175 & 1.010 & 0.762 \\
\hline Pct Filterer & -0.465 & 0.206 & 0.285 \\
\hline Pct Scraper & -1.636 & -1.562 & 2.009 \\
\hline Pct Shredder & 0.593 & -0.566 & 0.601 \\
\hline Pct Predator & 0.110 & 0.606 & 0.118 \\
\hline Pct Omnivore & -0.989 & -0.700 & 1.180 \\
\hline Pct Unknown & 0.915 & -0.405 & 0.416 \\
\hline Amphibian Richness & -1.738 & $-2.502 *$ & $5.533^{* * *}$ \\
\hline Larval Amphibian Richness & $0.027^{*}$ & $0.018^{*}$ & $4.775 * *$ \\
\hline Adult Amphibian Richness & 0.703 & -0.432 & 1.228 \\
\hline Total No Amph & -1.331 & -2.007 & $3.062 *$ \\
\hline Mean No Amph & -1.331 & -2.007 & $3.062 *$ \\
\hline Total No Adult Amph & -0.054 & -1.265 & 1.738 \\
\hline Mean No Adult Amph & 0.102 & -1.163 & 1.598 \\
\hline Total No Larval Amph & $-2.465^{*}$ & -2.337 & $3.511^{* *}$ \\
\hline Mean No Larval Amph & -1.674 & -0.739 & -1.469 \\
\hline Total Larval Amph Biomass $\left(100 \mathrm{~g} / \mathrm{m}^{2}\right)$ & -1.558 & -1.058 & 1.694 \\
\hline Mean Larval Amph Biomass $\left(100 \mathrm{~g} / \mathrm{m}^{2}\right)$ & -1.558 & -1.058 & 1.694 \\
\hline Mean Amph Density (ind/m²) & -1.326 & -2.003 & $3.059 *$ \\
\hline Pct Grassland Amph & -1.018 & 0.392 & 0.643 \\
\hline Pct Forest Amph & 1.429 & 1.061 & $3.041^{*}$ \\
\hline Pct Lotic Amph & $2.472 *$ & -0.003 & 0.079 \\
\hline Pct Lentic Amph & -0.723 & 1.009 & 1.269 \\
\hline
\end{tabular}


Table 12. Combined larval and adult amphibian density (individuals $/ \mathrm{m}^{2}$ ) observed on reclaimed mine perimeter channels and reference sites for four sample periods. Mean and standard deviation by site type are given in the last two rows. Perimeter channel sites are listed by increasing age since reclamation.

\begin{tabular}{lccccc}
\hline Site Code & March & May & June & July & $\begin{array}{c}\text { Mean } \\
\text { Density }\end{array}$ \\
\hline P_WO & 0.1 & 0.1 & 0.1 & 0.1 & 0.1 \\
P_AR & 0.7 & 1.3 & 1.0 & 1.1 & 1.0 \\
P_ST & 0.0 & 0.5 & 0.0 & 0.0 & 0.1 \\
P_SU & 0.0 & 0.2 & 0.3 & 0.3 & 0.2 \\
P_BH & 0.0 & 0.6 & 0.1 & 0.0 & 0.2 \\
R_HC & 0.0 & 0.5 & 0.3 & 0.0 & 0.2 \\
R_LF & 0.6 & 0.8 & 1.2 & 0.1 & 0.7 \\
R_ME & 1.1 & 1.2 & 1.2 & 0.8 & 1.0 \\
R_MW & 0.1 & 0.5 & 0.5 & 0.5 & 0.4 \\
R_WO & 0.0 & 0.1 & 0.1 & 0.0 & 0.0 \\
\hline Perimeter & $0.2 \pm 0.3$ & $0.5 \pm 0.5$ & $0.3 \pm 0.4$ & $0.3 \pm 0.5$ & $0.3 \pm 0.4$ \\
Reference & $0.3 \pm 0.5$ & $0.6 \pm 0.4$ & $0.6 \pm 0.5$ & $0.3 \pm 0.3$ & $0.5 \pm 0.4$ \\
\hline
\end{tabular}


Table 13. Frog and salamander species expected (Exp) to occur in grassland and forest in southwestern West Virginia, based on Green and Pauley (1987) compared to those actually observed (Obs) as (a) adults during visual encounter surveys (VES) (seen or heard), in (l) larval surveys, or (b) for both larval and VES. The preceding "p" indicates individuals encountered in perimeter sites and " $r$ " indicates occurance within reference sites.

\begin{tabular}{|c|c|c|c|c|c|}
\hline \multirow{2}{*}{ Aquatic Salamanders } & & \multicolumn{2}{|c|}{ Grassland } & \multicolumn{2}{|c|}{ Forest } \\
\hline & & Exp & Obs & Exp & Obs \\
\hline Appalachian Seal Salamander & Desmognathus monticola & & & $\mathrm{x}$ & r.a \\
\hline Eastern Hellbender & Cryptobranchus alleganiensis & & & $\mathrm{x}$ & \\
\hline Midland Mud Salamander & Pseudotriton montanus & & & $\mathrm{x}$ & \\
\hline Mudpuppy & Necturus maculosus & $\mathrm{x}$ & & $\mathrm{x}$ & \\
\hline Northern Dusky Salamander & Desmognathus fuscus & & & $\mathrm{x}$ & r.b \\
\hline Northern Red Salamander & Pseudotriton ruber & $\mathrm{x}$ & & $\mathrm{x}$ & \\
\hline Northern Two-lined Salamander & Eurycea bislineata & & & $\mathrm{x}$ & r.a \\
\hline Red-spotted Newt & Notophthalmus v. viridenscens & $\mathrm{x}$ & p.b & $\mathrm{x}$ & \\
\hline Southern Two-lined Salamander & Eurycea cirrigera & & & $\mathrm{x}$ & r.l \\
\hline Spring Salamander & Gyrinophilus porphyriticus & & & $\mathrm{x}$ & r.a \\
\hline \multicolumn{6}{|l|}{ Terrestrial Salamanders } \\
\hline Cumberland Plateau Salamander & Plethodon kentucki & & & $\mathrm{x}$ & \\
\hline Four-toed Salamander & Hemidactylium scutatum & & & $\mathrm{x}$ & \\
\hline Green Salamander & Aneides aeneus & & & $\mathrm{x}$ & \\
\hline Jefferson Salamander & Ambystoma jeffersonianum & & & $\mathrm{x}$ & \\
\hline Longtail Salamander & Eurycea longicauda & $\mathrm{x}$ & & $\mathrm{x}$ & \\
\hline Marbled Salamander & Ambystoma орасит & & & $\mathrm{x}$ & \\
\hline Ravine Salamander & Plethodon richmondi & & & $\mathrm{x}$ & \\
\hline Redback Salamander & Plethodon cinereus & & & $\mathrm{x}$ & \\
\hline Slimy Salamander & Plethodon glutinosus & & & $\mathrm{x}$ & \\
\hline Spotted Salamander & Ambystoma maculatum & & & $\mathrm{x}$ & \\
\hline Wehrle's Salamander & Plethodon wherlei & & & $\mathrm{x}$ & \\
\hline Ambystoma species & Ambystoma sp. & & p.l & $\mathrm{x}$ & \\
\hline \multicolumn{6}{|l|}{ Aquatic Frogs } \\
\hline Bullfrog & Rana catesbeiana & $\mathrm{x}$ & p.a & $\mathrm{x}$ & \\
\hline Greenfrog & Rana clamitans & $\mathrm{x}$ & p.b & $\mathrm{x}$ & \\
\hline Pickerel frog & Rana palustris & $\mathrm{x}$ & p.a & $\mathrm{x}$ & \\
\hline Northern Leopard Frog & Rana pipiens & $\mathrm{x}$ & & $\mathrm{x}$ & \\
\hline \multicolumn{6}{|l|}{ Terrestrial Frogs } \\
\hline Eastern American Toad & Bufo americana & $x$ & p.l & & \\
\hline Eastern Spadefoot & Scaphiopus holbrookii & & & $\mathrm{x}$ & \\
\hline Fowler's Toad & Bufo woodhouseii & & & & \\
\hline Gray Treefrog & Hyla chrysoscelis & & p.l & $\mathrm{x}$ & \\
\hline Mountain Chorus Frog & Pseudacris brachyphona & & & $\mathrm{x}$ & \\
\hline Northern Peeper & Pseudacris c. cricifer & & p.l & $\mathrm{x}$ & r.a \\
\hline Wood Frog & Rana sylvatica & & & $\mathrm{x}$ & \\
\hline
\end{tabular}


Table 14. Macroinvertebrate measurements from reclaimed mine perimeter channels and reference sites. Mean and standard deviation by site type are given in the last two rows. Perimeter channel sites are listed in increasing age since reclamation. Statistical significance is indicated by $*=<0.05$.

\begin{tabular}{|c|c|c|c|c|c|c|c|c|c|c|c|}
\hline Site Code & $\begin{array}{l}\text { WVSCI } \\
\text { Rating }\end{array}$ & $\begin{array}{l}\text { WVSCI } \\
\text { Score* }\end{array}$ & $\begin{array}{c}\text { Pct } \\
\text { Chironomid }\end{array}$ & Pct Tolerant & $\begin{array}{c}\text { Pct } \\
\text { EPT* }^{*}\end{array}$ & $\begin{array}{c}\text { EPT } \\
\text { Richness* }\end{array}$ & $\begin{array}{c}\text { Total } \\
\text { Richness* }\end{array}$ & $\begin{array}{c}\text { Total } \\
\text { Inverts }\end{array}$ & $\begin{array}{c}\text { Pct } 2 \\
\text { Dominant }\end{array}$ & \# 1 Dominant & \# 2 Dominant \\
\hline P_WO & Poor & 33 & 94 & 100 & 0 & 0 & 2 & 1329 & 98 & Chironomidae & Unknown Diptera \\
\hline P_AR & Marginal & 64 & 10 & 40 & 19 & 1 & 8 & 86 & 39 & Snails & Baetidae \\
\hline P_ST & Marginal & 56 & 29 & 29 & 8 & 1 & 7 & 191 & 75 & Cyclopoida & Chironomidae \\
\hline P_SU & Poor & 44 & 85 & 87 & 0 & 2 & 10 & 1384 & 92 & Chironomidae & Cyclopoida \\
\hline P_BH & Poor & 44 & 72 & 92 & 0 & 0 & 13 & 823 & 86 & Chironomidae & Oligochaeta \\
\hline R_HC & Poor & 52 & 38 & 58 & 6 & 1 & 6 & 47 & 62 & Chironomidae & Cyclopoida \\
\hline R_LF & Excellent & 88 & 0 & 11 & 89 & 6 & 7 & 145 & 57 & Ameletidae & Peltoperlidae \\
\hline R_ME & Good & 80 & 20 & 23 & 74 & 4 & 7 & 301 & 69 & Peltoperlidae & Chironomidae \\
\hline R_MW & Good & 76 & 34 & 38 & 52 & 7 & 10 & 512 & 57 & Chironomidae & Ameletidae \\
\hline R_WO & Poor & 45 & 68 & 82 & 18 & 2 & 4 & 60 & 87 & Chironomidae & Capniidae/Leuctridae \\
\hline Perimeter & - & $48 \pm 12$ & $58 \pm 37$ & $70 \pm 33$ & $5 \pm 8$ & $1 \pm 1$ & $8 \pm 4$ & $763 \pm 611$ & $78 \pm 23$ & - & - \\
\hline Reference & - & $68 \pm 19$ & $32 \pm 25$ & $42 \pm 28$ & $48 \pm 35$ & $4 \pm 3$ & $7 \pm 2$ & $213 \pm 195$ & $66 \pm 12$ & - & - \\
\hline
\end{tabular}


Table 15. Percent of macroinvertebrates by feeding guild observed on reclaimed mine perimeter channels and reference sites. Guilds include collector gatherer (CG), filterer (FI), scraper (SC), shredder (SH), predator (PR), omnivore (OM), and unknown (UN). Mean and standard deviation by site type are given in the last two rows. Perimeter channel sites are listed in increasing age since reclamation. Statistical significance is indicated by $*=<0.05$.

\begin{tabular}{lccccccc}
\hline Site Code & CG & FI & SC & SH & PR & OM & UN* \\
\hline P_WO & 94 & 0 & 0 & 0 & 6 & 0 & 0 \\
P_AR & 30 & 0 & 21 & 9 & 21 & 19 & 0 \\
P_ST & 70 & 2 & 2 & 0 & 4 & 22 & 0 \\
P_SU & 93 & 0 & 6 & 0 & 1 & 0 & 1 \\
P_BH & 82 & 8 & 2 & 0 & 8 & 0 & 0 \\
R_HC & 55 & 0 & 17 & 6 & 2 & 17 & 2 \\
R_LF & 61 & 0 & 0 & 20 & 14 & 0 & 6 \\
R_ME & 25 & 0 & 0 & 69 & 0 & 0 & 5 \\
R_MW & 61 & 0 & 0 & 22 & 6 & 0 & 10 \\
R_WO & 82 & 0 & 0 & 18 & 0 & 0 & 0 \\
\hline Perimeter & $74 \pm 26$ & $2 \pm 3$ & $6 \pm 9$ & $2 \pm 4$ & $8 \pm 8$ & $8 \pm 11$ & $0 \pm 0$ \\
Reference & $57 \pm 20$ & $0 \pm 0$ & $3 \pm 8$ & $27 \pm 24$ & $5 \pm 6$ & $3 \pm 8$ & $5 \pm 4$ \\
\hline
\end{tabular}


Table 16. Mean organic matter transport distances and retention rate for reclaimed mine perimeter channels and reference sites. Mean and standard deviation by site type are given in the last two rows. Perimeter channel sites are listed in increasing age since reclamation. Statistical significance is indicated by $*=<0.05$.

\begin{tabular}{|c|c|c|c|c|c|c|c|}
\hline Site Code & $\begin{array}{c}\text { Mean Leaf } \\
\text { Distance (m) }\end{array}$ & $\begin{array}{l}\text { Mean Cum Stick } \\
\text { Distance }(\mathrm{m})^{*}\end{array}$ & $\begin{array}{c}\text { Mean Cum } \\
\text { Stick Dist/Day* }\end{array}$ & Retention Rate & $\begin{array}{l}\text { Pct Sticks } \\
\text { Retained* }\end{array}$ & $\begin{array}{c}\text { Dowels Exiting } \\
\text { Reach* }\end{array}$ & Gradient \\
\hline P_WO & 2.6 & 37.2 & 0.2 & -0.0089 & 36 & 32 & 6 \\
\hline P_AR & 0.0 & 0.0 & 0.0 & -0.0782 & 100 & 0 & 1 \\
\hline P_ST & 0.0 & 0.0 & 0.0 & -0.0782 & 100 & 0 & 1 \\
\hline P_SU & 0.0 & 0.0 & 0.0 & -0.0782 & 100 & 0 & 1 \\
\hline P_BH & 0.0 & 0.0 & 0.0 & -0.0782 & 100 & 0 & 1 \\
\hline R_HC & 0.4 & 11.7 & 0.1 & -0.0367 & 84 & 8 & 17 \\
\hline R_LF & 0.2 & 30.2 & 0.2 & -0.0204 & 64 & 18 & 6 \\
\hline R_ME & 0.0 & 22.9 & 0.1 & -0.0216 & 66 & 17 & 16 \\
\hline R_MW & 0.8 & 28.6 & 0.1 & -0.0147 & 52 & 24 & 8 \\
\hline R_WO & 0.8 & 41.1 & 0.2 & -0.0066 & 28 & 36 & 7 \\
\hline Perimeter & $0.5 \pm 1.2$ & $7.4 \pm 16.6$ & $0.0 \pm 0.1$ & $-0.0644 \pm 0.0310$ & $87 \pm 29$ & $6 \pm 14$ & $2 \pm 2$ \\
\hline Reference & $0.4 \pm 0.3$ & $26.9 \pm 10.7$ & $0.1 \pm 0.1$ & $-0.0200 \pm 0.0111$ & $59 \pm 21$ & $21 \pm 10$ & $11 \pm 5$ \\
\hline
\end{tabular}


Table 17. Dissolved organic carbon measures (mg/L) for reference sites and reclaimed mine perimeter channels. Reference sites did not contain water at the time of autumn sampling. Autumn samples for P_ST were contaminated. Site mean is the mean of spring, summer, and winter only. Mean and standard deviation by site type are given in the last two rows. Perimeter channel sites are listed in increasing age since reclamation. Statistical significance is indicated by $*=<0.05$.

\begin{tabular}{lccccc}
\hline Site Code & Spring & Summer & Autumn & Winter* & Site Mean \\
\hline P_WO & 0.42 & 1.10 & 1.29 & 1.18 & 0.90 \\
P_AR & 5.71 & 1.53 & 2.99 & 3.20 & 3.48 \\
P_ST & 7.74 & 2.34 & - & 2.94 & 4.34 \\
P_SU & 8.99 & 7.49 & 8.01 & 1.72 & 6.07 \\
P_BH & 1.72 & 1.47 & 4.41 & 1.52 & 1.57 \\
R_HC & 0.32 & 0.27 & - & 0.67 & 0.42 \\
R_LF & 3.43 & 1.42 & - & 0.98 & 1.94 \\
R_ME & 2.61 & 0.86 & - & 0.92 & 1.46 \\
R_MW & 2.77 & 1.39 & - & 1.18 & 1.78 \\
R_WO & 3.37 & 1.29 & - & 1.12 & 1.93 \\
\hline Perimeter & $4.92 \pm 3.73$ & $2.79 \pm 2.65$ & $4.18 \pm 3.10$ & $2.11 \pm 0.90$ & $3.27 \pm 2.09$ \\
Reference & $2.50 \pm 1.27$ & $1.05 \pm 0.49$ & - & $0.97 \pm 0.20$ & $1.51 \pm 0.64$ \\
\hline
\end{tabular}


Table 18. Total dissolved carbon measures (mg/L) for reference sites and reclaimed mine perimeter channels. Reference sites did not contain water at the time of autumn sampling. Autumn samples for P_ST were contaminated. Site mean is the mean of spring, summer, and winter only. Mean and standard deviation by site type are given in the last two rows. Perimeter channel sites are listed in increasing age since reclamation. Statistical significance is indicated by $*=<0.05$.

\begin{tabular}{lccccc}
\hline Site Code & Spring* & Summer* & Autumn & Winter* & Site Mean* \\
\hline P_WO & 44.4 & 26.3 & 2.0 & 2.1 & 24.3 \\
P_AR & 28.1 & 18.9 & 2.9 & 2.9 & 16.6 \\
P_ST & 26.1 & 33.7 & - & 3.0 & 20.9 \\
P_SU & 22.8 & 29.0 & 5.1 & 5.8 & 19.2 \\
P_BH & 13.6 & 18.3 & 3.3 & 3.1 & 11.7 \\
R_HC & 1.2 & 2.1 & - & 1.1 & 1.5 \\
R_LF & 5.3 & 3.2 & - & 1.4 & 3.3 \\
R_ME & 4.0 & 3.7 & - & 1.5 & 3.0 \\
R_MW & 4.1 & 3.1 & - & 1.6 & 2.9 \\
R_WO & 4.1 & 1.7 & - & 1.6 & 2.5 \\
\hline Perimeter & $27.0 \pm 5.0$ & $25.2 \pm 3.0$ & $3.3 \pm 0.6$ & $3.4 \pm 0.6$ & $18.5 \pm 2.1$ \\
Reference & $3.7 \pm 0.7$ & $2.7 \pm 0.4$ & - & $1.4 \pm 0.1$ & $2.6 \pm 0.3$ \\
\hline
\end{tabular}


Table 19. Mean total weight (g), mean organic (g) and inorganic mass (g), percent organic, percent organic mass lost, decomposition rate $(\mathrm{k})$. and processing power observed on reclaimed mine perimeter channels and reference sites after 325 days of exposure. Mean and standard deviation by site type are given in the last two rows. Perimeter channel sites are listed in increasing age since reclamation. Statistical significance is indicated by $*=<0.05$.

\begin{tabular}{|c|c|c|c|c|c|c|c|c|}
\hline Site Code & $\begin{array}{l}\text { Days of } \\
\text { Exposure }\end{array}$ & $\begin{array}{l}\text { Mean Total } \\
\text { Weight* }\end{array}$ & $\begin{array}{c}\text { Mean } \\
\text { Organic } \\
\text { Mass } \\
\end{array}$ & $\begin{array}{c}\text { Mean } \\
\text { Inorganic } \\
\text { Mass } \\
\end{array}$ & $\begin{array}{l}\text { Mean \% } \\
\text { Organic* }\end{array}$ & $\begin{array}{c}\text { Mean \% } \\
\text { Organic } \\
\text { Mass Lost* }\end{array}$ & Decomp Rate* & $\begin{array}{c}\text { Process Power } \\
* 100\end{array}$ \\
\hline P_WO & 199 & 10.2 & 5.6 & 4.6 & 57 & 45 & -0.00268 & 0.002 \\
\hline P_AR & 325 & 5.8 & 5.1 & 0.7 & 88 & 50 & -0.00231 & 0.018 \\
\hline P_ST & 328 & 6.0 & 5.5 & 0.5 & 92 & 45 & -0.00167 & 0.013 \\
\hline P_SU & 329 & 5.6 & 5.2 & 0.4 & 92 & 49 & -0.00205 & 0.016 \\
\hline P_BH & 325 & 5.7 & 5.4 & 0.3 & 94 & 47 & -0.00194 & 0.015 \\
\hline R_HC & 200 & 11.0 & 6.0 & 5.0 & 57 & 41 & -0.00248 & 0.009 \\
\hline R_LF & 327 & 1.4 & 1.1 & 0.3 & 82 & 89 & -0.00666 & 0.014 \\
\hline R_ME & 329 & 3.4 & 2.9 & 0.5 & 85 & 71 & -0.00380 & 0.008 \\
\hline R_MW & 328 & 5.1 & 3.8 & 1.4 & 75 & 63 & -0.00297 & 0.004 \\
\hline R_WO & 326 & 5.6 & 5.3 & 0.3 & 94 & 48 & -0.00149 & 0.001 \\
\hline Perimeter & & $6.7 \pm 2.0$ & $5.3 \pm 0.2$ & $1.3 \pm 1.8$ & $85 \pm 16$ & $47 \pm 2$ & $-0.00213 \pm 0.00038$ & $0.013 \pm 0.006$ \\
\hline Reference & & $5.3 \pm 3.6$ & $3.8 \pm 1.9$ & $1.5 \pm 2.0$ & $78 \pm 14$ & $62 \pm 19$ & $-0.00348 \pm 0.00196$ & $0.007 \pm 0.005$ \\
\hline
\end{tabular}


Table 20. Correlation of parameters with decomposition rates and mean conductivity for reference sites and reclaimed mine perimeter channels. Mean and standard error are given in the first two rows.

\begin{tabular}{|c|c|c|c|c|}
\hline Response Variables & Perimeter Mean & $\begin{array}{l}\text { Reference } \\
\text { Mean }\end{array}$ & $\begin{array}{l}\text { Correlation } \\
\text { with Decomp }\end{array}$ & $\begin{array}{l}\text { Correlation } \\
\text { with } \\
\text { Conductivity }\end{array}$ \\
\hline Mean Q $\left(\mathrm{m}^{3} / \mathrm{s}\right)$ & $0.009(0.003)$ & $0.002(0.001)$ & & 0.76 \\
\hline \multicolumn{5}{|l|}{ Water Chemistry } \\
\hline Mean Alkalinity (mg/L) & $138(13)$ & $5(1)$ & & 0.84 \\
\hline Mean Ca (mg/L) & $163(31)$ & $21(15)$ & & 0.99 \\
\hline Mean Mg (mg/L) & $154(34)$ & $9(4)$ & & 0.96 \\
\hline Mean $\mathrm{SO}_{4}(\mathrm{mg} / \mathrm{L})$ & 1008 (196) & $32(20)$ & & 0.89 \\
\hline Mean Summer pH & $7.2(0.2)$ & $5.7(0.3)$ & & 0.80 \\
\hline Mean Spr Cond $(\mu \mathrm{S} / \mathrm{cm})$ & $2310(495)$ & $602(445)$ & & 0.95 \\
\hline Mean Sum Cond $(\mu \mathrm{S} / \mathrm{cm})$ & 2255 (488) & $642(501)$ & & 0.93 \\
\hline Mean Aut Cond $(\mu S / c m)$ & 2147 (448) & $133(75)$ & & 0.89 \\
\hline Mean Win Cond $(\mu \mathrm{S} / \mathrm{cm})$ & 2077 (395) & 147 (64) & & 0.93 \\
\hline Mean Cond $(\mu \mathrm{S} / \mathrm{cm})$ & 2197 (414) & $461(326)$ & & 1.00 \\
\hline Spring TDS (mg/L) & 1366 (294) & $76(28)$ & & 0.91 \\
\hline Summer TDS (mg/L) & $1818(455)$ & 157 (95) & & 0.96 \\
\hline Autumn TDS (mg/L) & - & - & & - \\
\hline Winter TDS (mg/L) & 1317 (269) & 77 (33) & & 0.91 \\
\hline Mean TDS (mg/L) & 1501 (279) & $103(50)$ & & 0.97 \\
\hline Spring TC (mg/L) & $27.0(5.0)$ & $3.7(0.7)$ & & 0.78 \\
\hline Summer TC (mg/L) & $25.2(3.0)$ & $2.7(0.4)$ & & 0.80 \\
\hline Mean TC (mg/L) & $18.5(2.1)$ & $2.6(0.3)$ & & 0.81 \\
\hline \multicolumn{5}{|l|}{ Habitat Assessment } \\
\hline EPA RBP & $78(6)$ & $150(10)$ & & -0.78 \\
\hline WV FCU & $3(0)$ & $9(0)$ & & -0.84 \\
\hline ORAM & $35(6)$ & $61(4)$ & & -0.80 \\
\hline
\end{tabular}


Table 20 continuted.

\begin{tabular}{|c|c|c|c|c|}
\hline Response Variables & Perimeter Mean & Reference Mean & $\begin{array}{c}\text { Correlation } \\
\text { with } \\
\text { Decomp } \\
\end{array}$ & $\begin{array}{l}\text { Correlation } \\
\text { with } \\
\text { Conductivity }\end{array}$ \\
\hline \multicolumn{5}{|l|}{ Vegetation } \\
\hline Pct Open Water & $13(6)$ & $0(0)$ & & 0.82 \\
\hline Species per $\mathrm{km}^{2}$ & $0.1(0.1)$ & $2.5(0.3)$ & & -0.80 \\
\hline Pct Canopy Cover & $4(4)$ & $91(1)$ & & -0.82 \\
\hline \multicolumn{5}{|l|}{ Macroinvertebrates } \\
\hline WVSCI Score & $48(5)$ & $68(8)$ & 0.75 & \\
\hline Pct EPT & $5(4)$ & $48(16)$ & 0.86 & -0.75 \\
\hline EPT Richness & $1(0)$ & $4(1)$ & & -0.80 \\
\hline Pct Predator & $8(3)$ & $5(3)$ & & 0.95 \\
\hline Pct Unknown & $0(0)$ & $5(2)$ & 0.83 & \\
\hline \multicolumn{5}{|l|}{ Amphibians } \\
\hline Total Adult Amph Sp & $1(0)$ & $2(0)$ & 0.78 & \\
\hline Total No Adult Amph & $5(3)$ & $28(13)$ & 0.80 & \\
\hline Pct Lotic Amph & $5(3)$ & $86(13)$ & & -0.75 \\
\hline Pct Lentic Amph & $89(8)$ & $54(8)$ & & 0.75 \\
\hline \multicolumn{5}{|l|}{ OM Processing } \\
\hline Decomp Rate & $0.0021(0.0002)$ & $0.0035(0.0009)$ & 1.00 & \\
\hline Mean Total Wt (g) (325 d) & $6.7(0.9)$ & $5.3(1.6)$ & & 0.77 \\
\hline Mean Organic Mass (g) (325 d) & $5.3(0.1)$ & $3.8(0.9)$ & -0.94 & \\
\hline Mean \% Org Mass Lost (325 d) & $47(1)$ & $62(9)$ & 0.95 & \\
\hline \multicolumn{5}{|l|}{ OM Retention } \\
\hline Mean Cum Stick Distance (m) & $7.44(7.44)$ & $26.89(4.81)$ & 0.76 & \\
\hline Mean Cum Stick Dist/ Day & $0.04(0.04)$ & $0.14(0.02)$ & 0.76 & \\
\hline
\end{tabular}


Table 21. Ecological units (EU) ratios, $\mathrm{EU}_{\mathrm{I}}$ ratios (calculated using ideal reference means), perimeter means, reference means, and ideal reference means for reclaimed mine perimeter channels and reference sites. Species parameters are standardized by the area of aquatic feature sampled.

\begin{tabular}{lccccc}
\hline \multicolumn{1}{c}{ Response Variables } & Perimeter Mean & Reference Mean & Ideal Ref Mean & EU Ratio & $\begin{array}{c}\text { EU I } \\
\text { Ratios }\end{array}$ \\
\hline Mean Larval Amph Biomass $\left(100 \mathrm{~g} / \mathrm{m}^{2}\right)$ & $1.33(1.03)$ & $0.05(0.02)$ & $0.07(0.02)$ & 28 & 19 \\
Mean Cond $(\mu \mathrm{S} / \mathrm{cm})$ & $2197(414)$ & $461(326)$ & $61(2)$ & 5 & 36 \\
Retention Rate & $-0.0644(0.0139)$ & $-0.0199(0.0049)$ & $-0.0189(0.0021)$ & 3.2 & 3.4 \\
Mean DOC $(\mathrm{mg} / \mathrm{L})$ & $3.51(0.94)$ & $1.51(0.28)$ & $1.73(0.14)$ & 2.3 & 2.0 \\
Processing Power *100 & $0.013(0.003)$ & $0.007(0.002)$ & $0.009(0.003)$ & 1.8 & 1.5 \\
Pct Lentic Amph & $89(8)$ & $54(8)$ & $61(11)$ & 0.97 & 0.86 \\
Total Invert Biomass $\left(\mathrm{g} / \mathrm{m}^{2}\right)$ & $31.8(18.9)$ & $34.5(14.9)$ & $44.2(22.3)$ & 0.92 & 0.72 \\
WVSCI Score & $48(5)$ & $68(8)$ & $81(3)$ & 0.71 & 0.59 \\
Total Invertebrate Richness & $8(2)$ & $7(1)$ & $8(1)$ & 0.71 & 0.60 \\
Decomp Rate & $0.0021(0.0002)$ & $0.0035(0.0009)$ & $0.0045(0.0011)$ & 0.61 & 0.48 \\
EPA RBP & $78(6)$ & $150(10)$ & $134(1)$ & 0.52 & 0.59 \\
EPT Richness & $1(0)$ & $4(1)$ & $6(1)$ & 0.13 & 0.09 \\
Pct EPT & $5(4)$ & $48(16)$ & $72(11)$ & 0.10 & 0.06 \\
Pct Lotic Amph & $5(3)$ & $86(13)$ & $99(1)$ & 0.03 & 0.03 \\
\hline
\end{tabular}


Figures

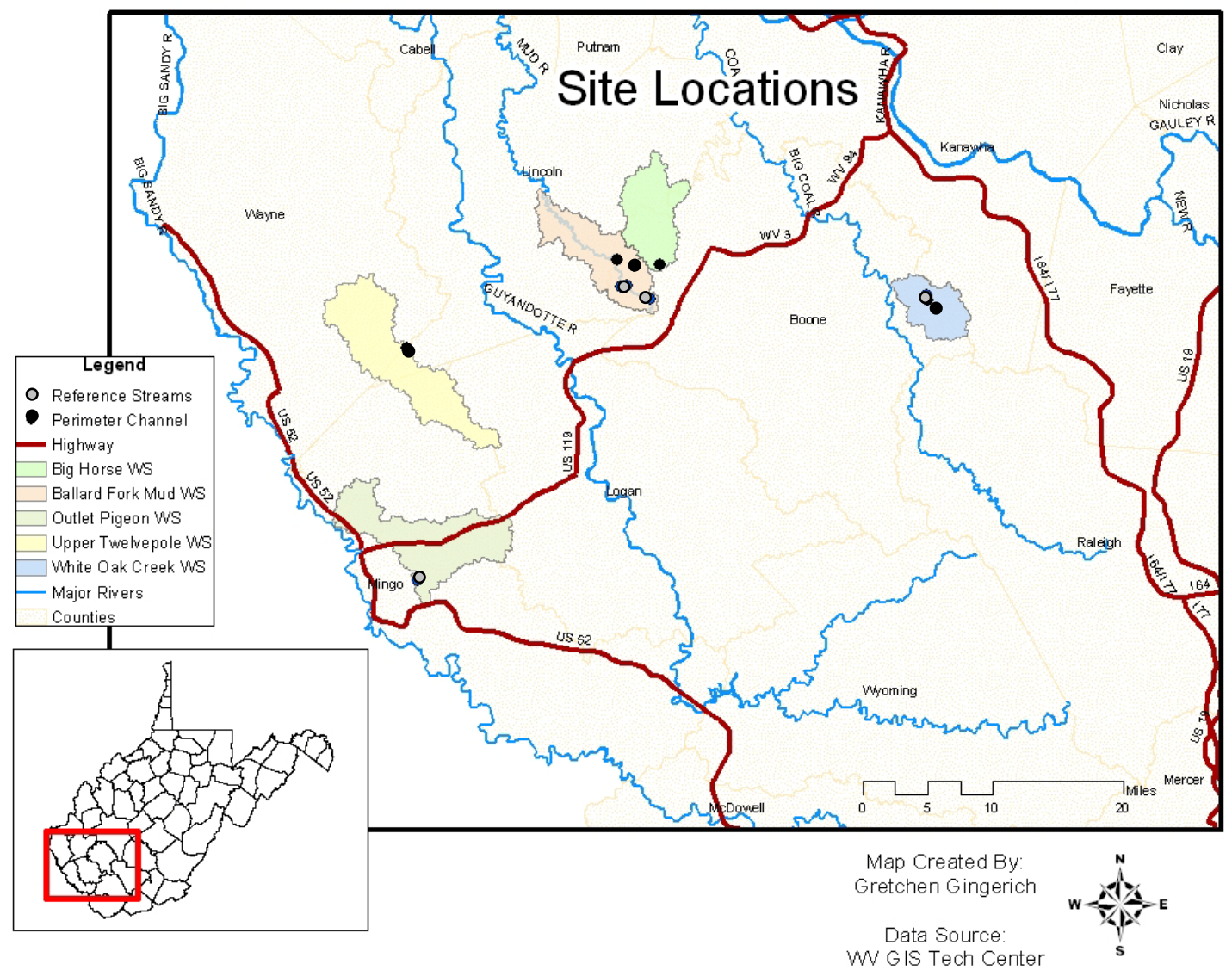

Figure 1. Site locations and HUC 12 watersheds for reference sites (gray dots) and perimeter channels (black dots). 


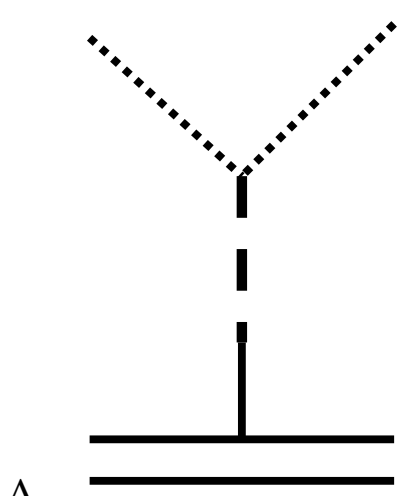

A.

Figure 2. A.) A typical headwater system: two ephemeral streams (dotted line) feeding into an intermittent (dashed line), feeding into a perennial (solid line), and finally to a broad river. B.) A series of sediment ponds, or wetlands, on the perimeter of a valley-fill system. This system usually has an intermittent or perennial outflow off-site to a larger system. 


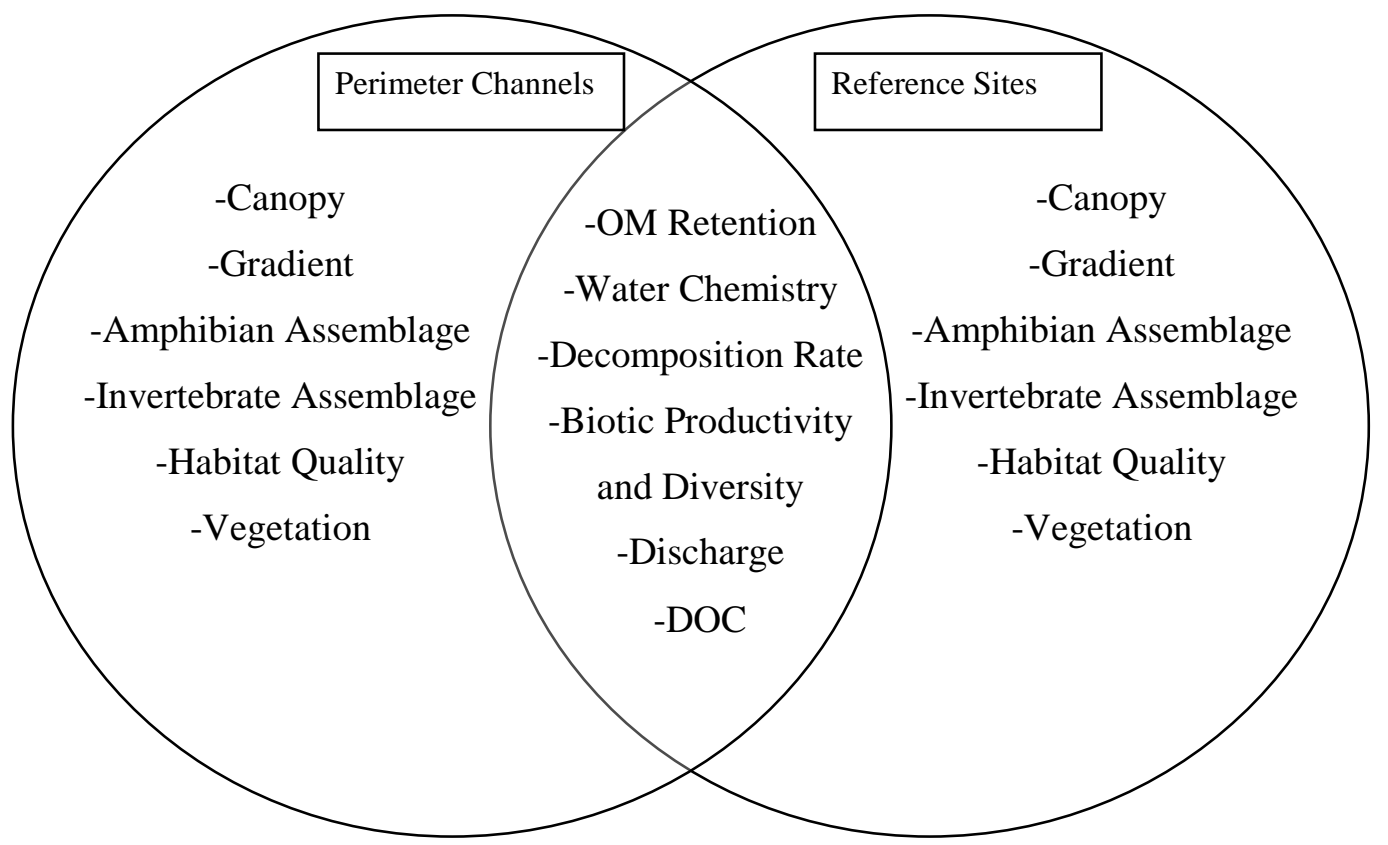

Figure 3. Directly comparable and indirectly comparable site parameters for reference and reclaimed surface mine sites. 




Figure 4. Seasonal $\mathrm{pH}$ for reclaimed mine perimeter channels and reference streams combined by site type. A range of $\mathrm{pH}$ 6.0-8.0 (dashed lines) is considered normal or acceptable. 


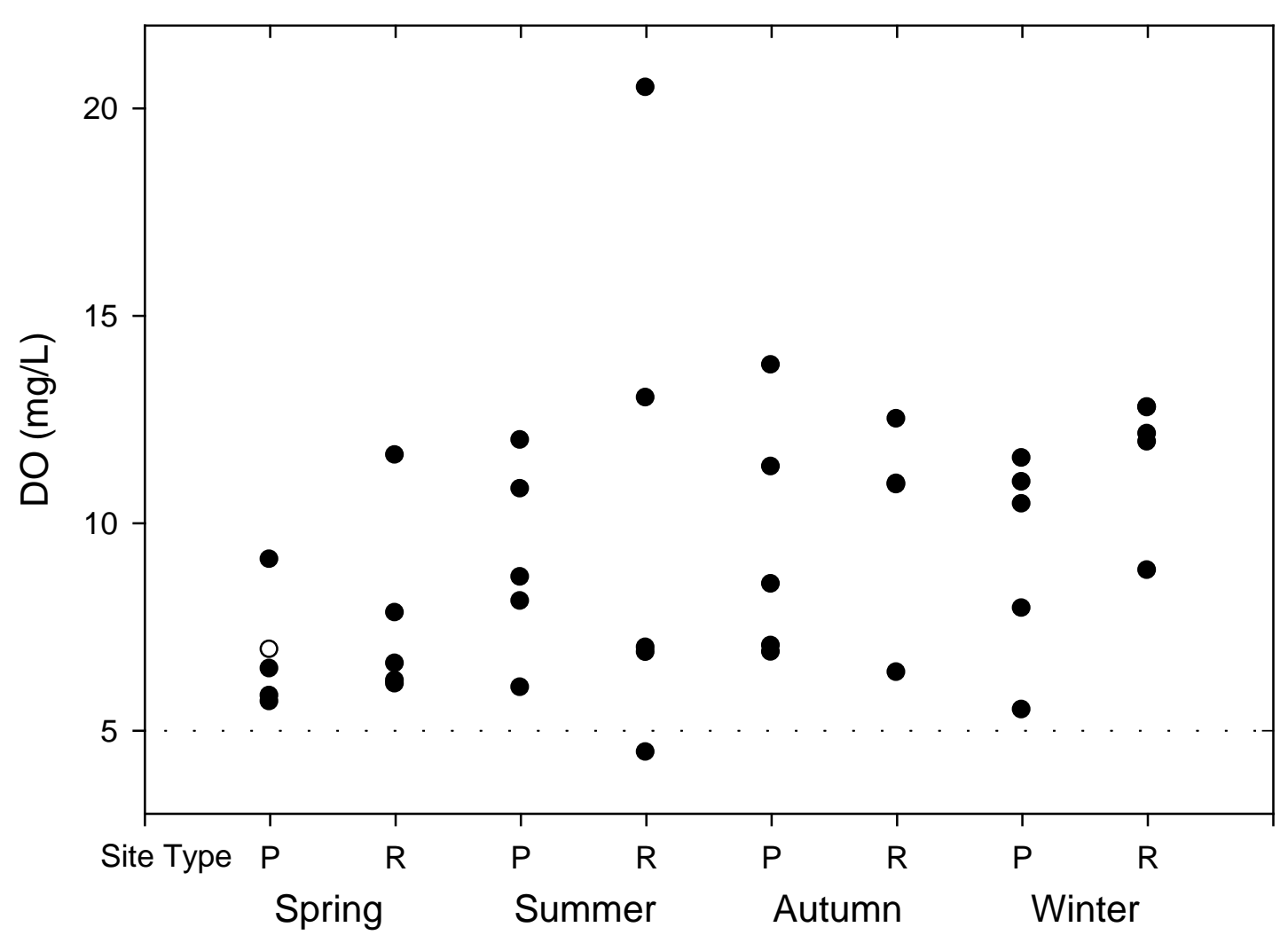

Figure 5. Seasonal dissolved oxygen (mg/L) for reclaimed mine perimeter channels and reference streams combined by site type. A limit of $5.0 \mathrm{mg} / \mathrm{L}$ (dashed line) is recommended for the health of aquatic life. 


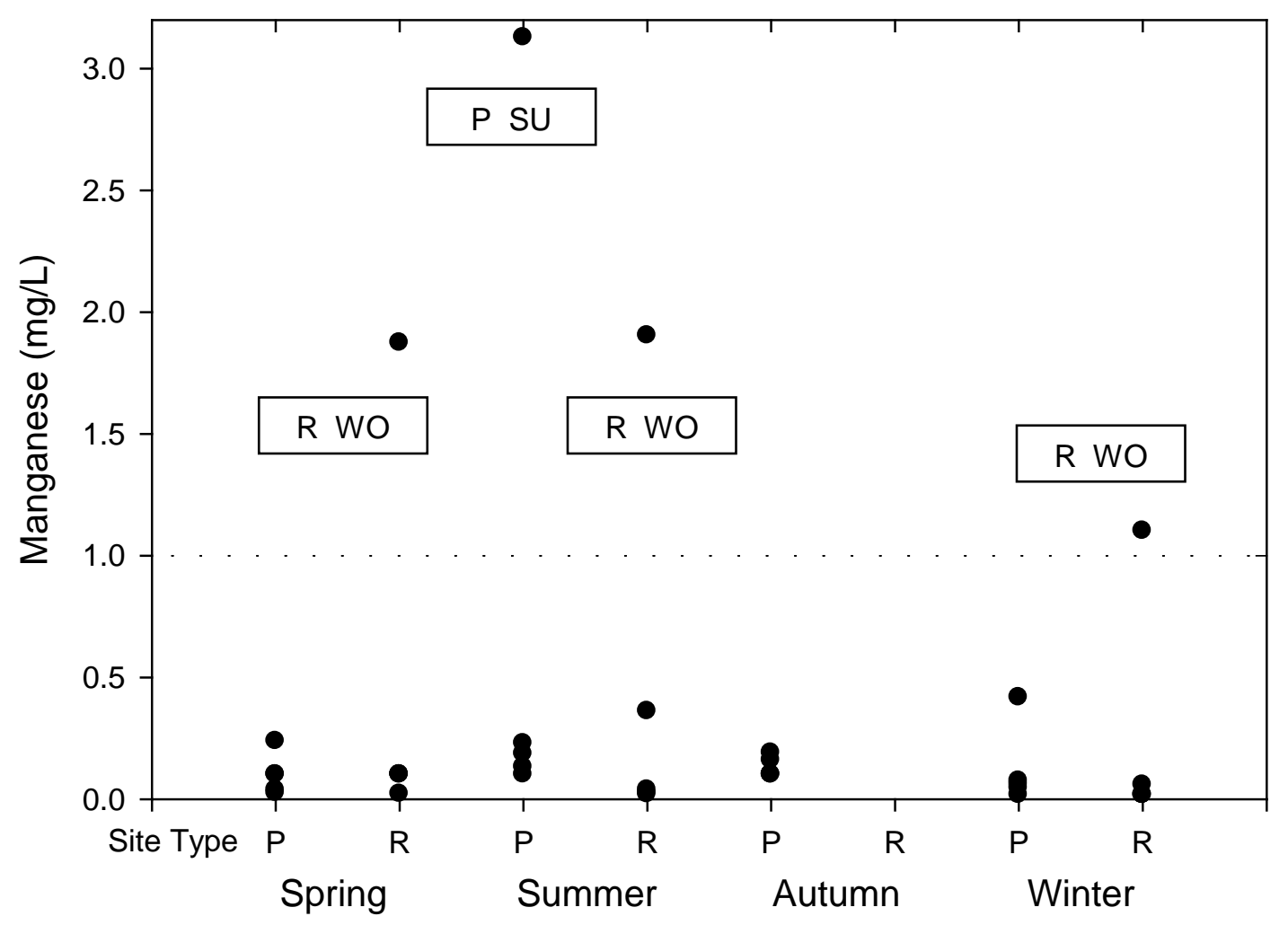

Figure 6. Seasonal manganese $(\mathrm{mg} / \mathrm{L})$ for reclaimed mine perimeter channels and reference streams combined by site type. The WWF limit is $1 \mathrm{mg} / \mathrm{L}$ (dashed line). Method detection limits (MDL) were $0.017 \mathrm{mg} / \mathrm{L}$. Reference sites did not contain enough water for sampling in autumn. 


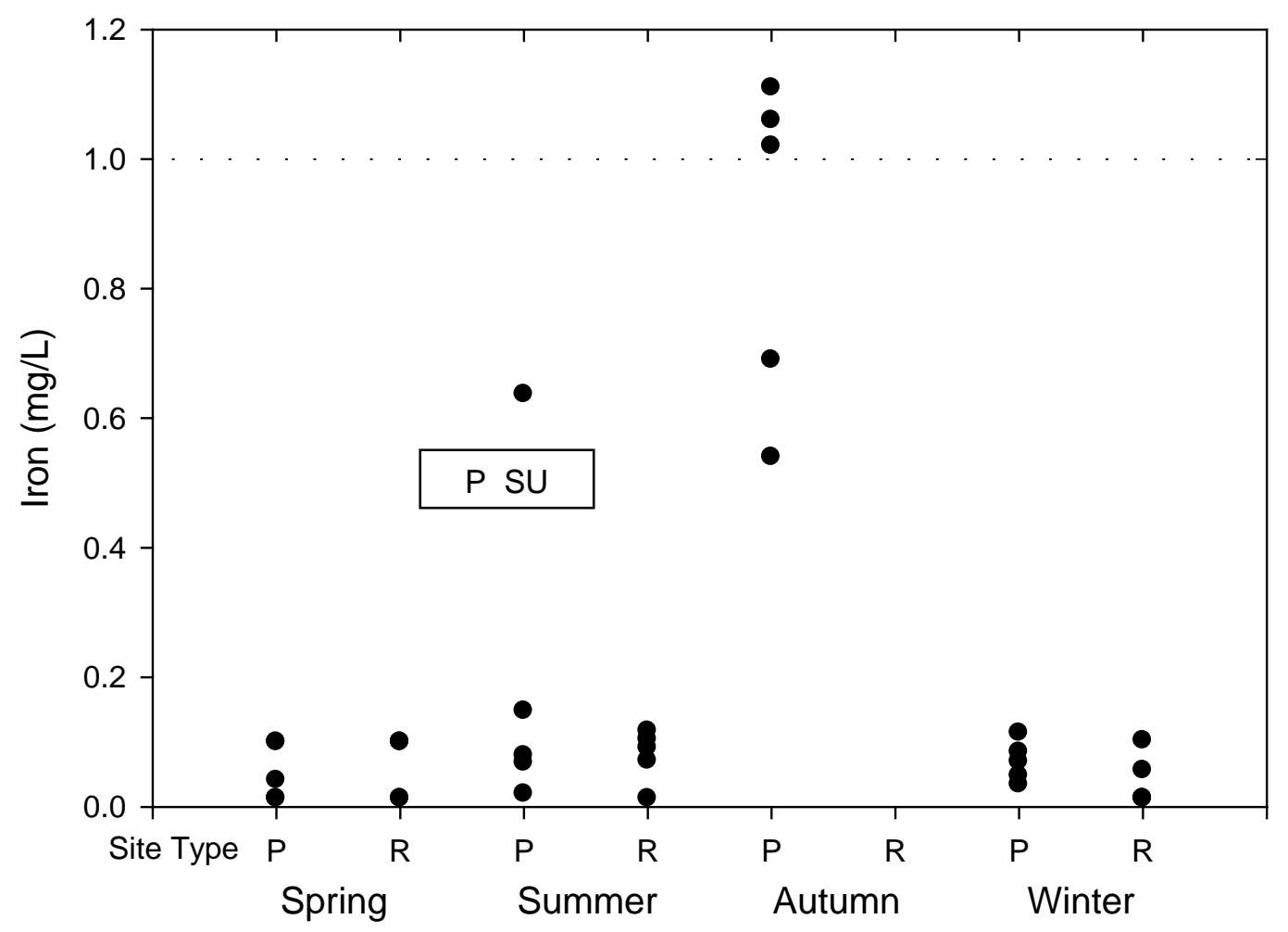

Figure 7. Seasonal iron $(\mathrm{mg} / \mathrm{L})$ for reclaimed mine perimeter channels and reference streams combined by site type. A limit of $1.0 \mathrm{mg} / \mathrm{L}$ is recommended for the health of aquatic life (dashed line). Reference sites did not contain enough water for sampling in autumn. 


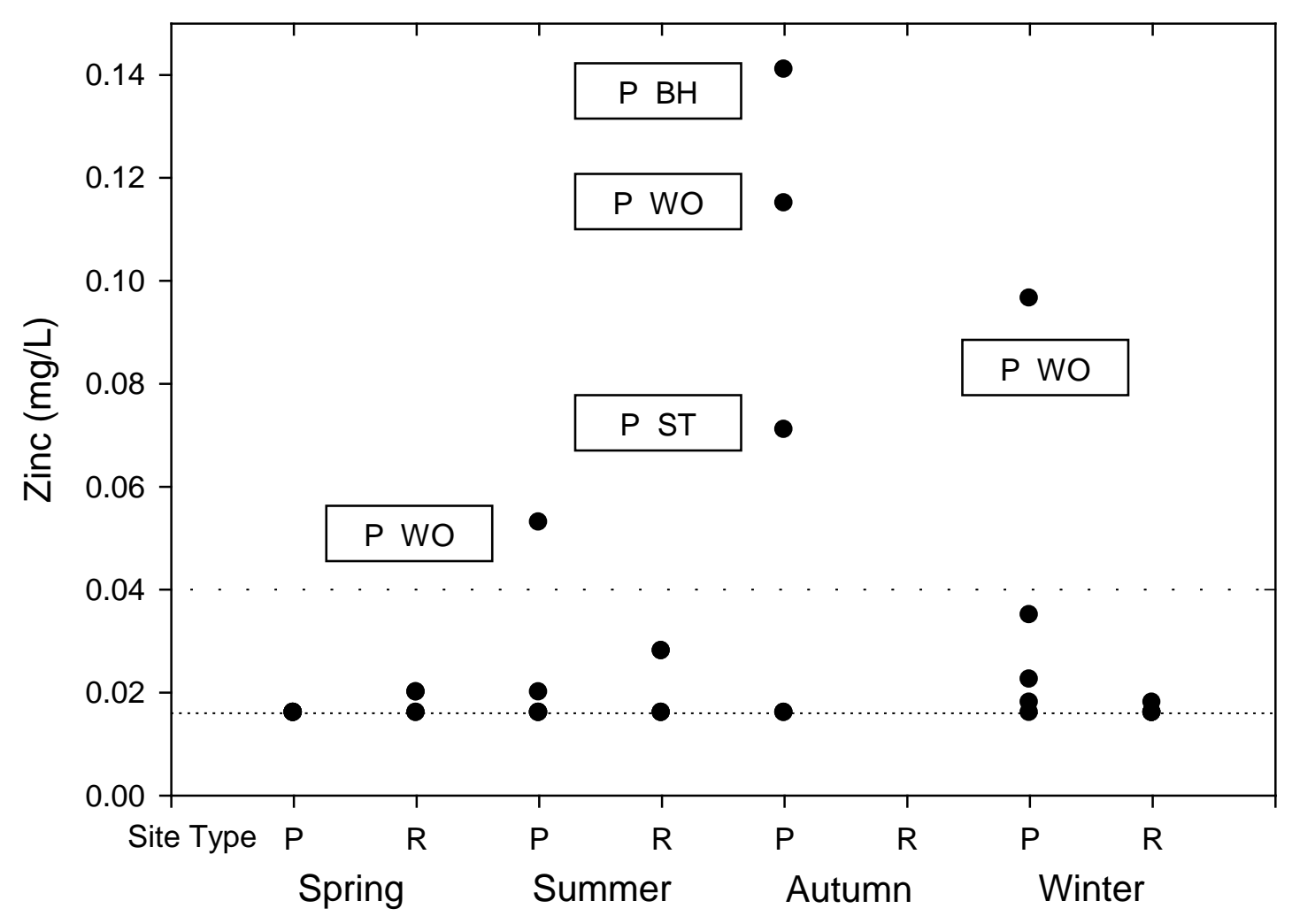

Figure 8. Seasonal zinc (mg/L) for reclaimed mine perimeter channels and reference streams combined by site type. MDL was $0.016 \mathrm{mg} / \mathrm{L}$ (dotted line). The recommended level for the health of aquatic life is $0.04 \mathrm{mg} / \mathrm{L}$ (dashed line). Reference sites did not contain enough water for sampling in autumn. 


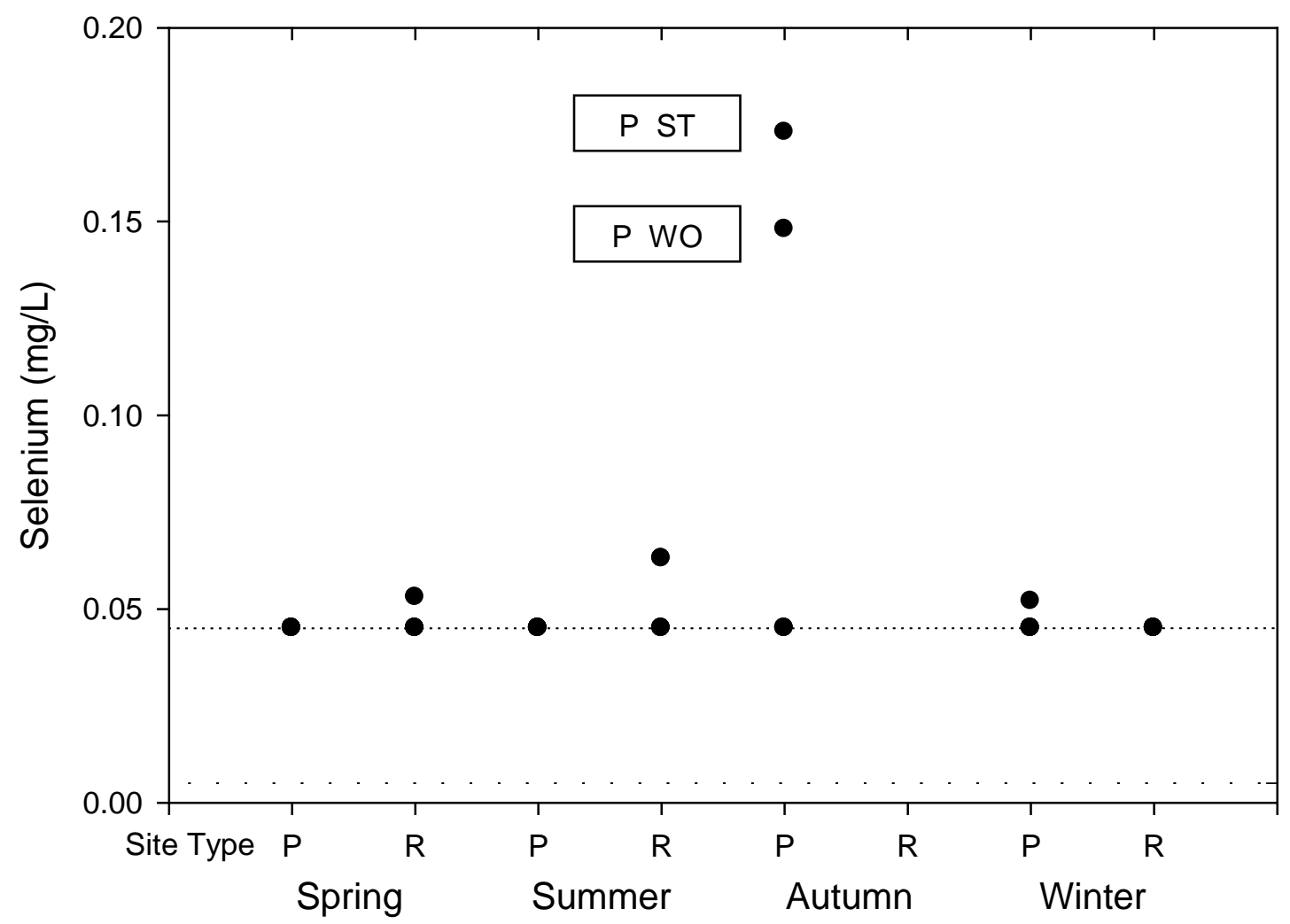

Figure 9. Seasonal selenium (mg/L) for reclaimed mine perimeter channels and reference streams combined by site type. The WWF limit is $0.005 \mathrm{mg} / \mathrm{L}$ (dashed line). MDL was $0.045 \mathrm{mg} / \mathrm{L}$ (dotted line). Reference sites did not contain enough water for sampling in autumn. 


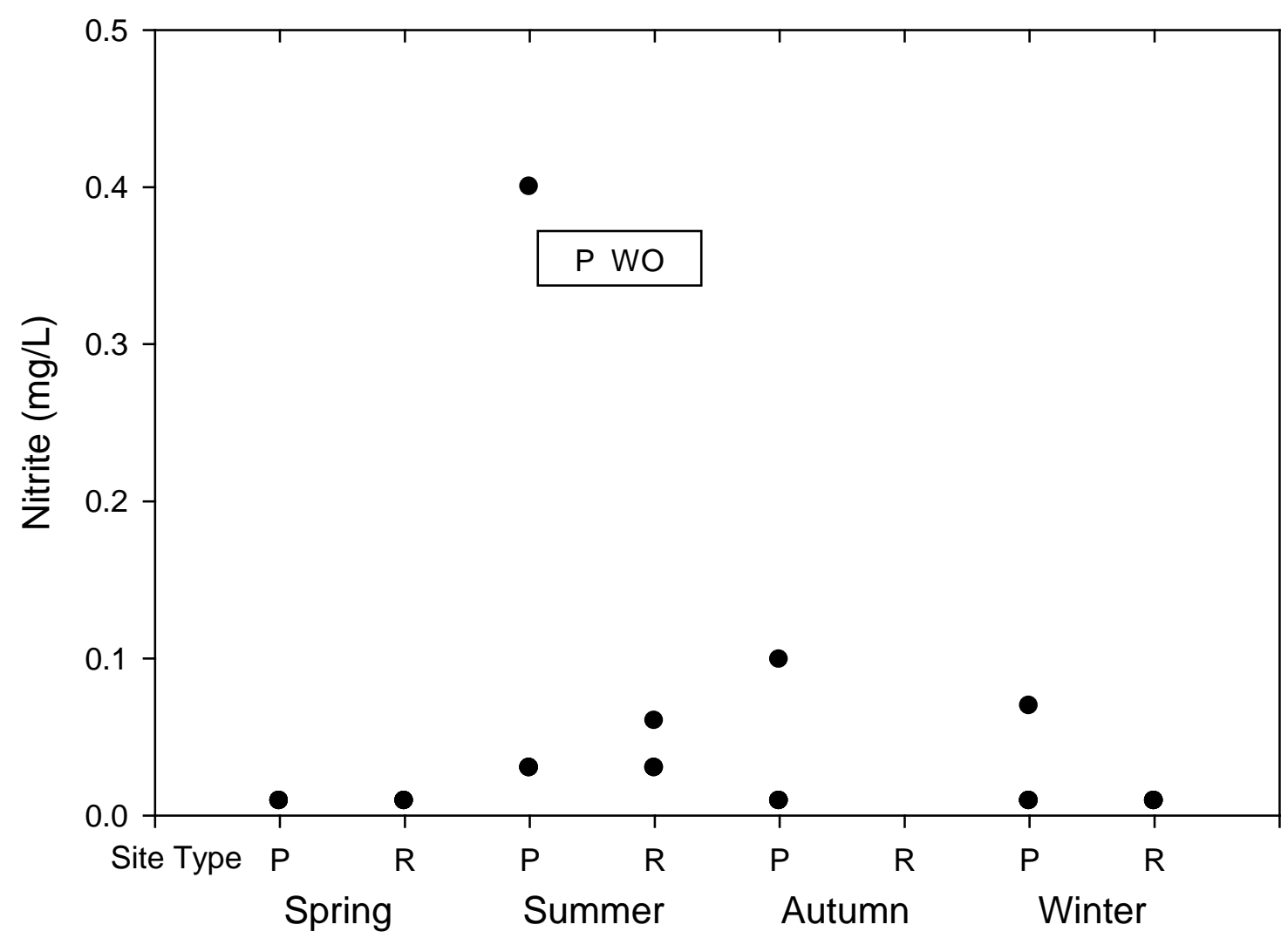

Figure 10. Seasonal nitrite $(\mathrm{mg} / \mathrm{L})$ for reclaimed mine perimeter channels and reference streams combined by site type. R_HC experienced a summer measure of $46.230 \mathrm{mg} / \mathrm{L}$ (not shown) after disturbance. Reference sites did not contain enough water for sampling in autumn. 




Figure 11. Seasonal nitrate (mg/L) for reclaimed mine perimeter channels and reference streams combined by site type. The WWF limit is $90 \mathrm{mg} / \mathrm{L}$ (dashed line). Reference sites did not contain enough water for sampling in autumn. 


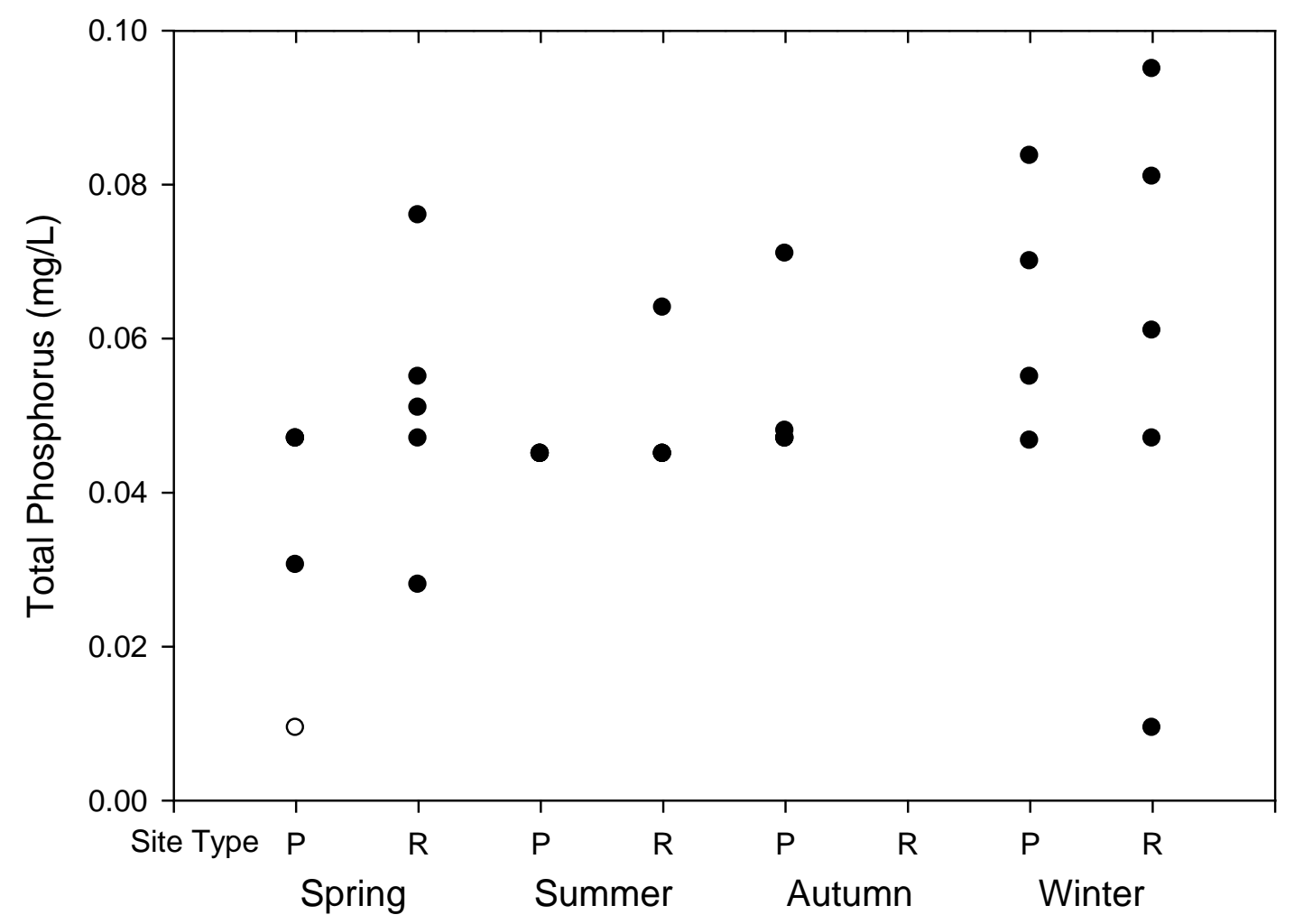

Figure 12. Seasonal total phosphorus (mg/L) for reclaimed mine perimeter channels and reference streams combined by site type. In 1986, EPA recommended a $0.1 \mathrm{mg} / \mathrm{L}$ limit for streams not emptying into reservoirs. Reference sites did not contain enough water for sampling in autumn. 


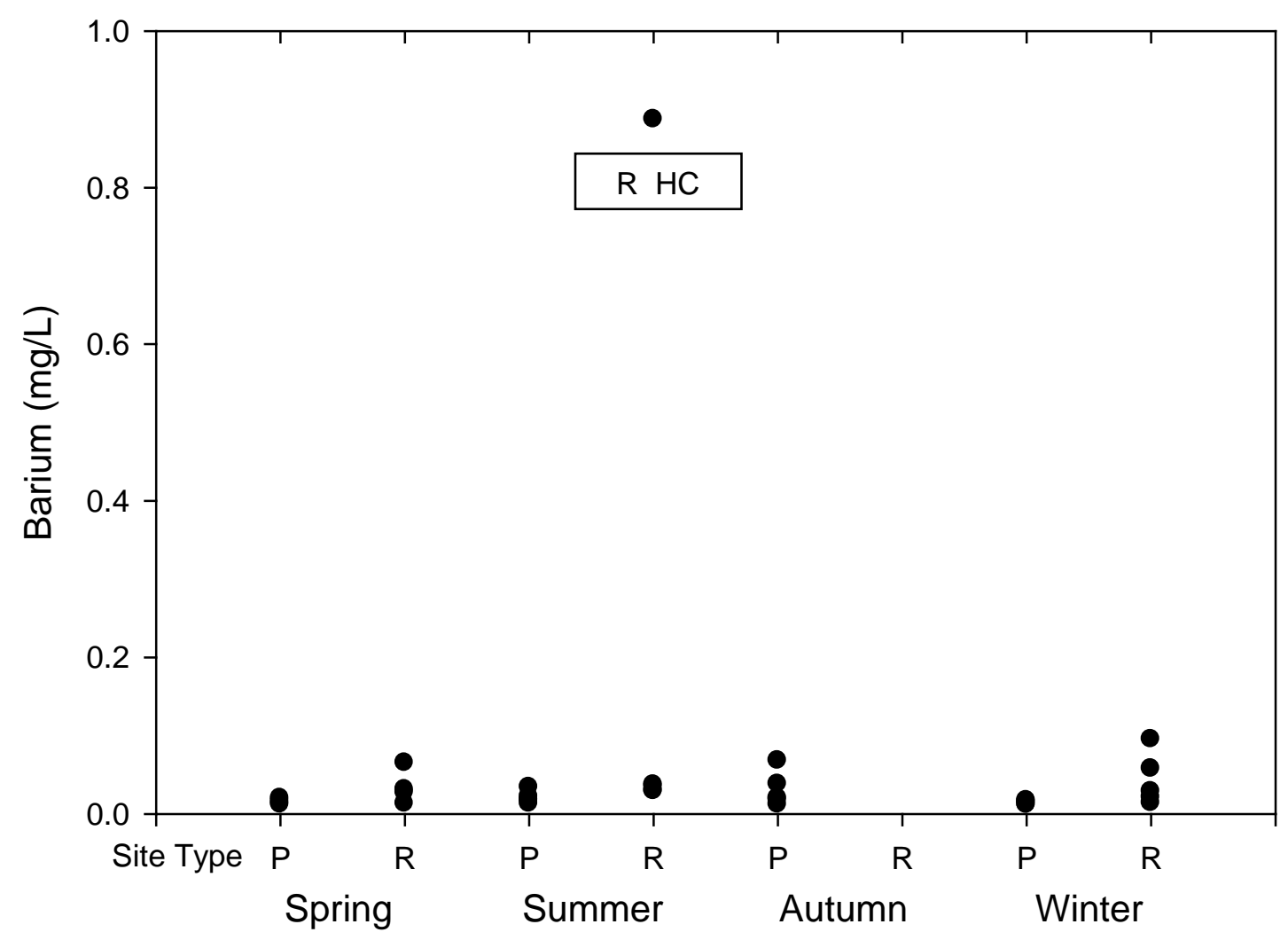

Figure 13. Seasonal barium (mg/L) for reclaimed mine perimeter channels and reference streams combined by site type. Reference sites did not contain enough water for sampling in autumn. 


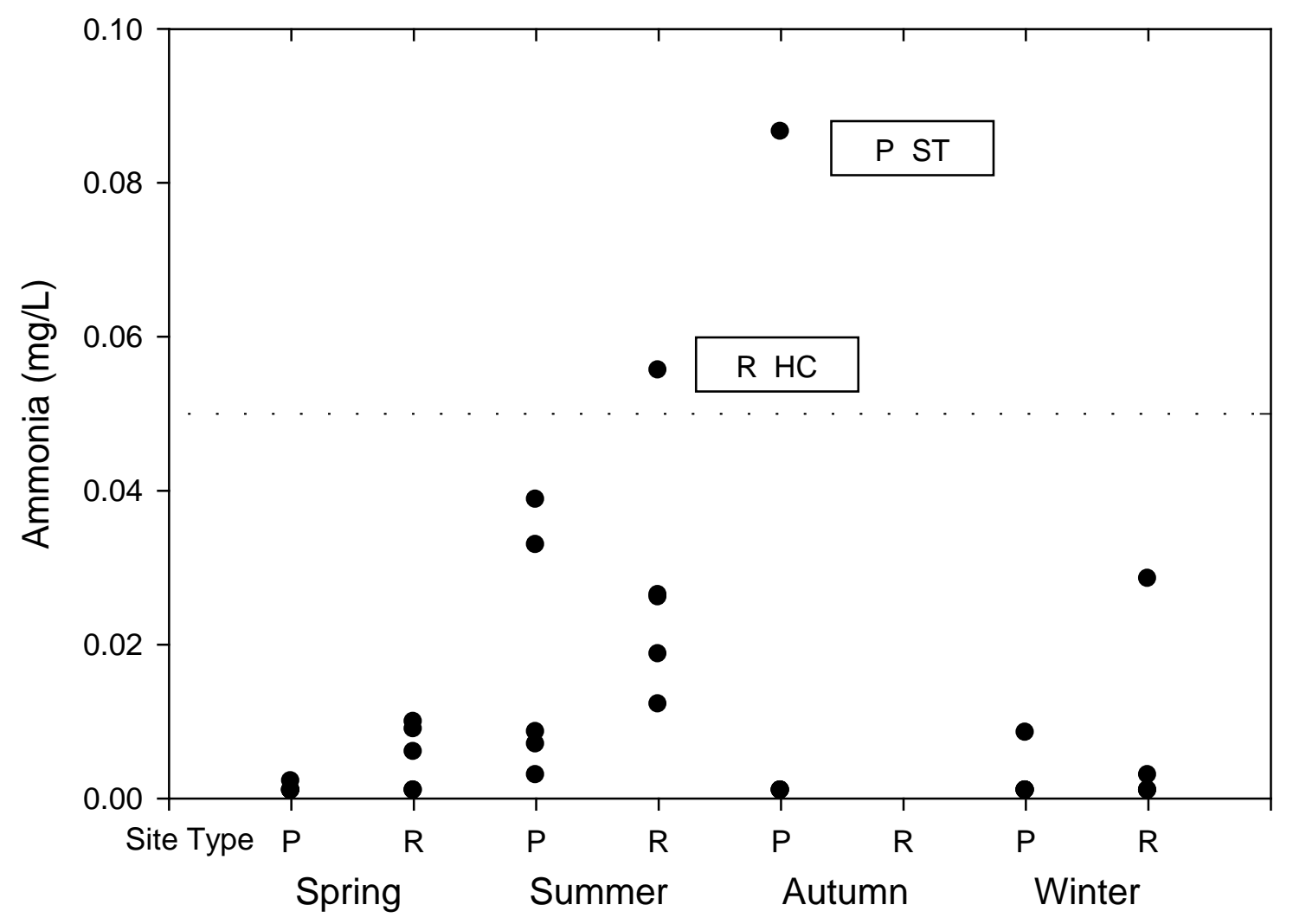

Figure 14. Seasonal ammonia (mg/L) for reclaimed mine perimeter channels and reference streams combined by site type. The recommended limit for aquatic life health is $0.05 \mathrm{mg} / \mathrm{L}$ (dashed line). Reference sites did not contain enough water for sampling in autumn. 


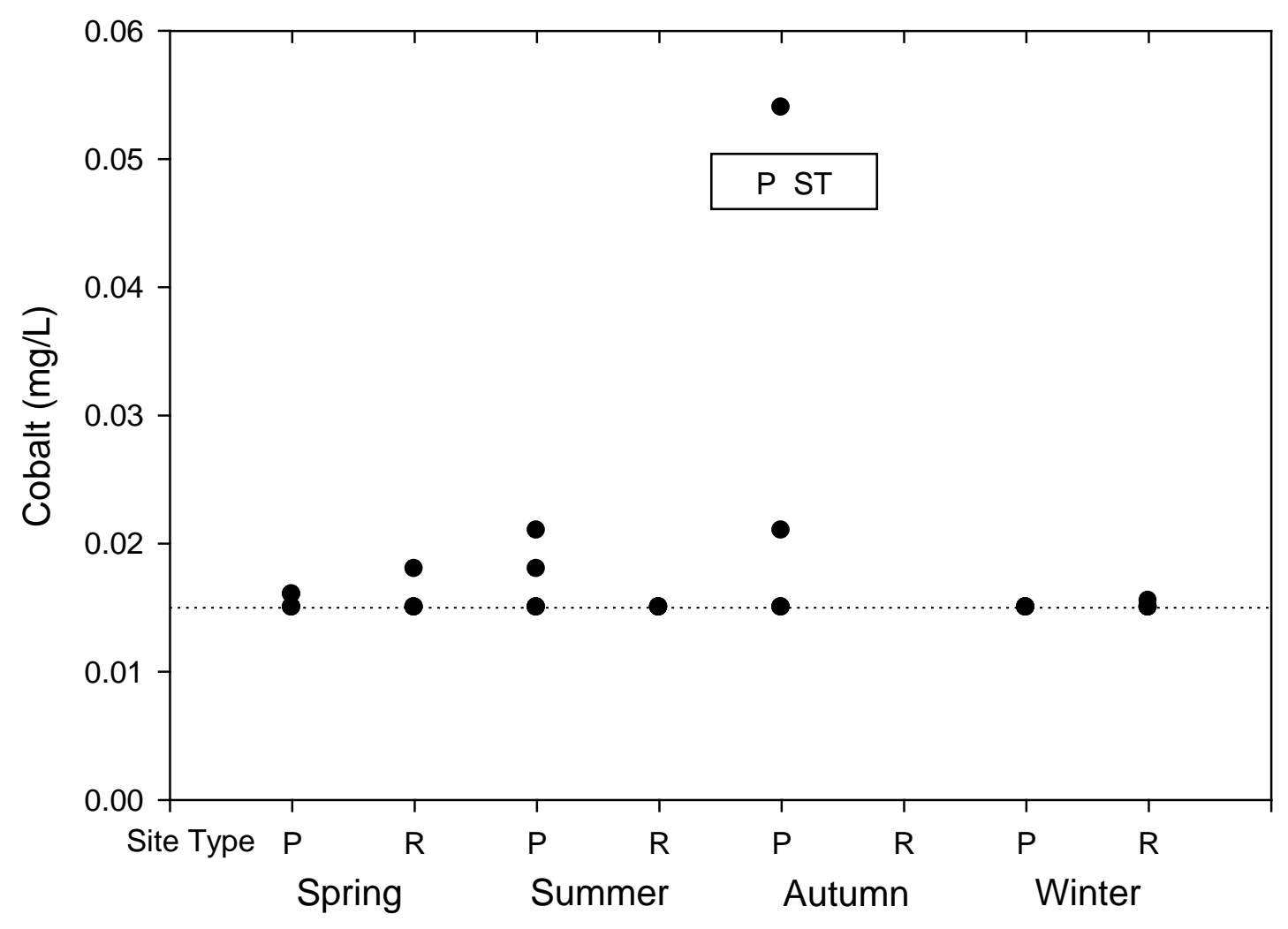

Figure 15. Seasonal cobalt (mg/L) for reclaimed mine perimeter channels and reference streams combined by site type. There is no recommended limit for aquatic health. MDL was $0.015 \mathrm{mg} / \mathrm{L}$ (dotted line). Reference sites did not contain enough water for sampling in autumn. 


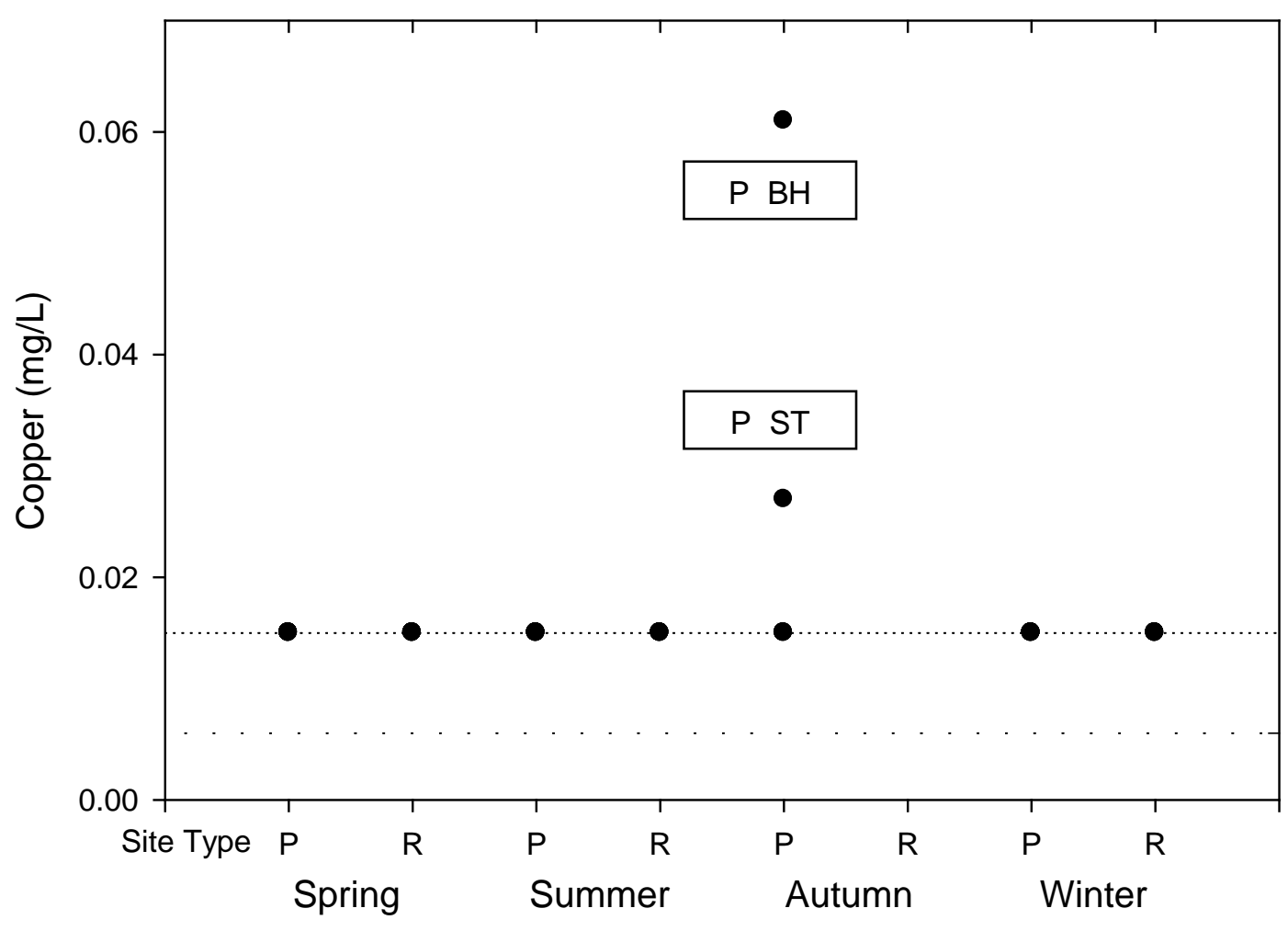

Figure 16. Seasonal copper $(\mathrm{mg} / \mathrm{L})$ for reclaimed mine perimeter channels and reference streams combined by site type. The WWF limit is $0.006 \mathrm{mg} / \mathrm{L}$ (dashed line). MDL was $0.015 \mathrm{mg} / \mathrm{L}$ (dotted line). Reference sites did not contain enough water for sampling in autumn. 




Figure 17. Seasonal cadmium (mg/L) for reclaimed mine perimeter channels and reference streams combined by site type. The WWF limit is $0.007 \mathrm{mg} / \mathrm{L}$ (dashed line). However, method detection limit (MDL) was 0.014 (dotted line). Reference sites did not contain enough water for sampling in autumn. 




Figure 18. Seasonal acidity $(\mathrm{mg} / \mathrm{L})$ for reclaimed mine perimeter channels and reference streams combined by site type. Reference sites did not contain enough water for sampling in autumn. 


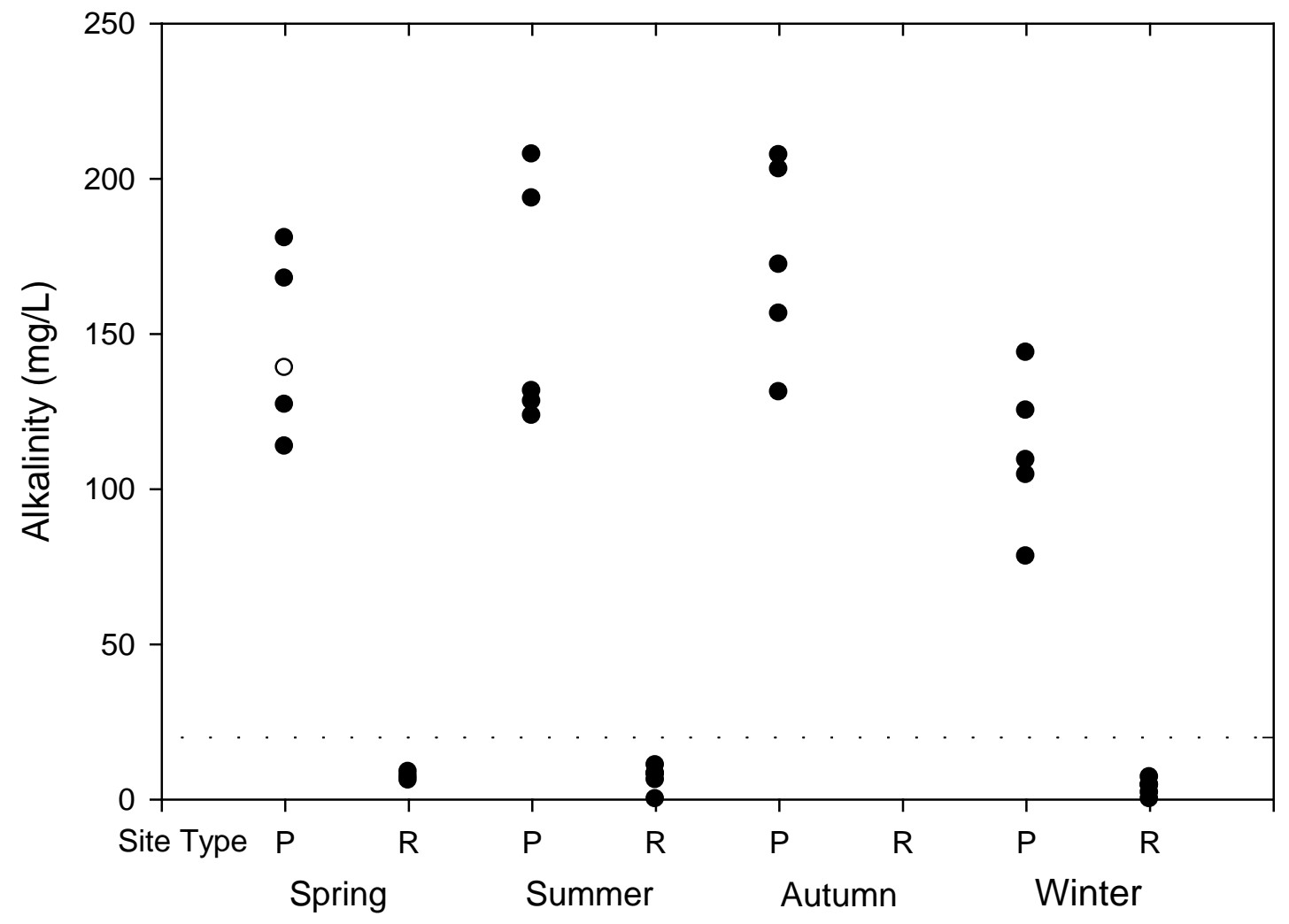

Figure 19. Seasonal alkalinity $(\mathrm{mg} / \mathrm{L})$ for reclaimed mine perimeter channels and reference streams combined by site type. An alkalinity of $>20 \mathrm{mg} / \mathrm{L}$ (dashed line) is considered to have good buffering capacity. Reference sites did not contain enough water for sampling in autumn. 


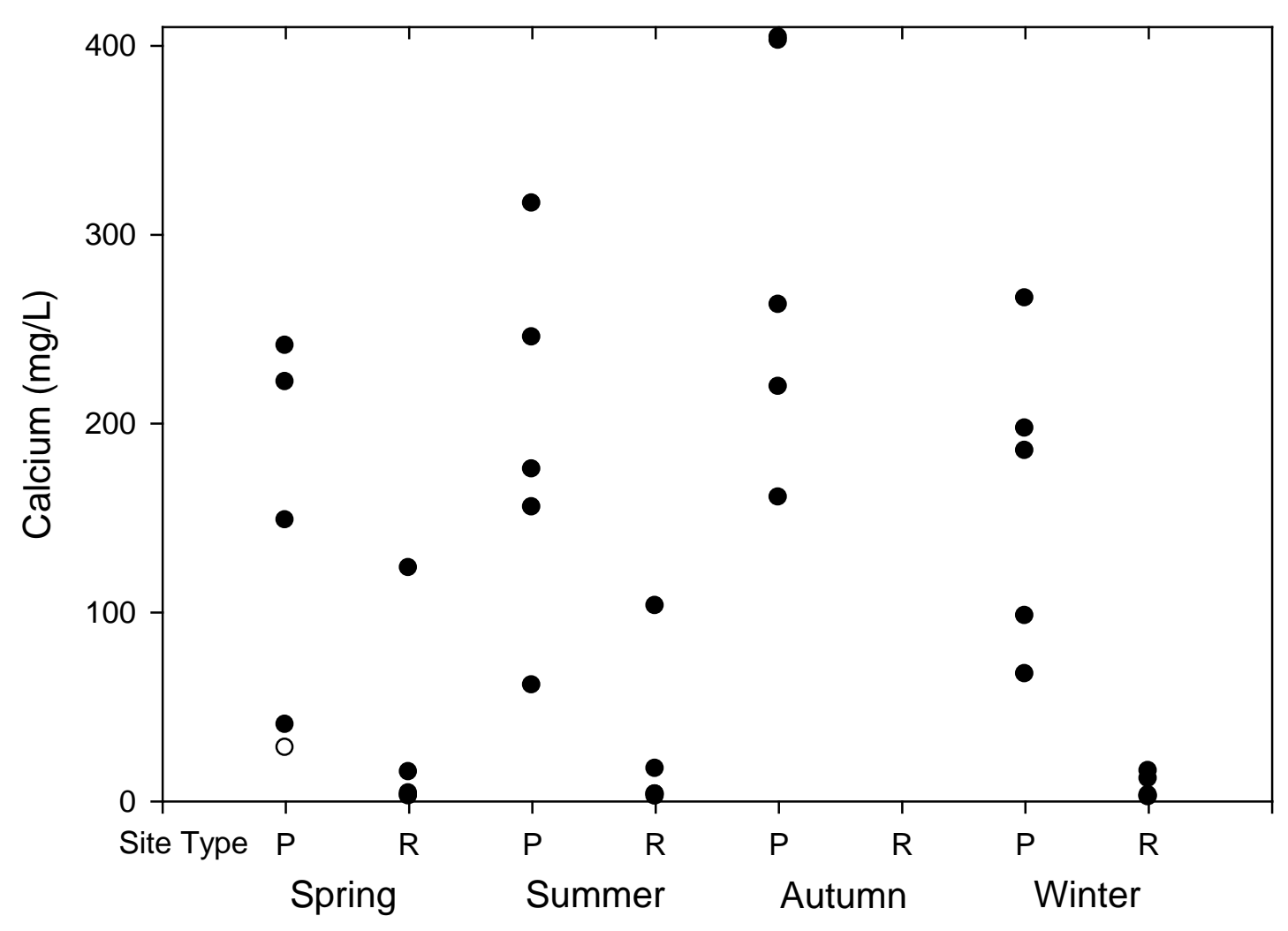

Figure 20. Seasonal calcium (mg/L) for reclaimed mine perimeter channels and reference streams combined by site type. Reference sites did not contain enough water for sampling in autumn. 


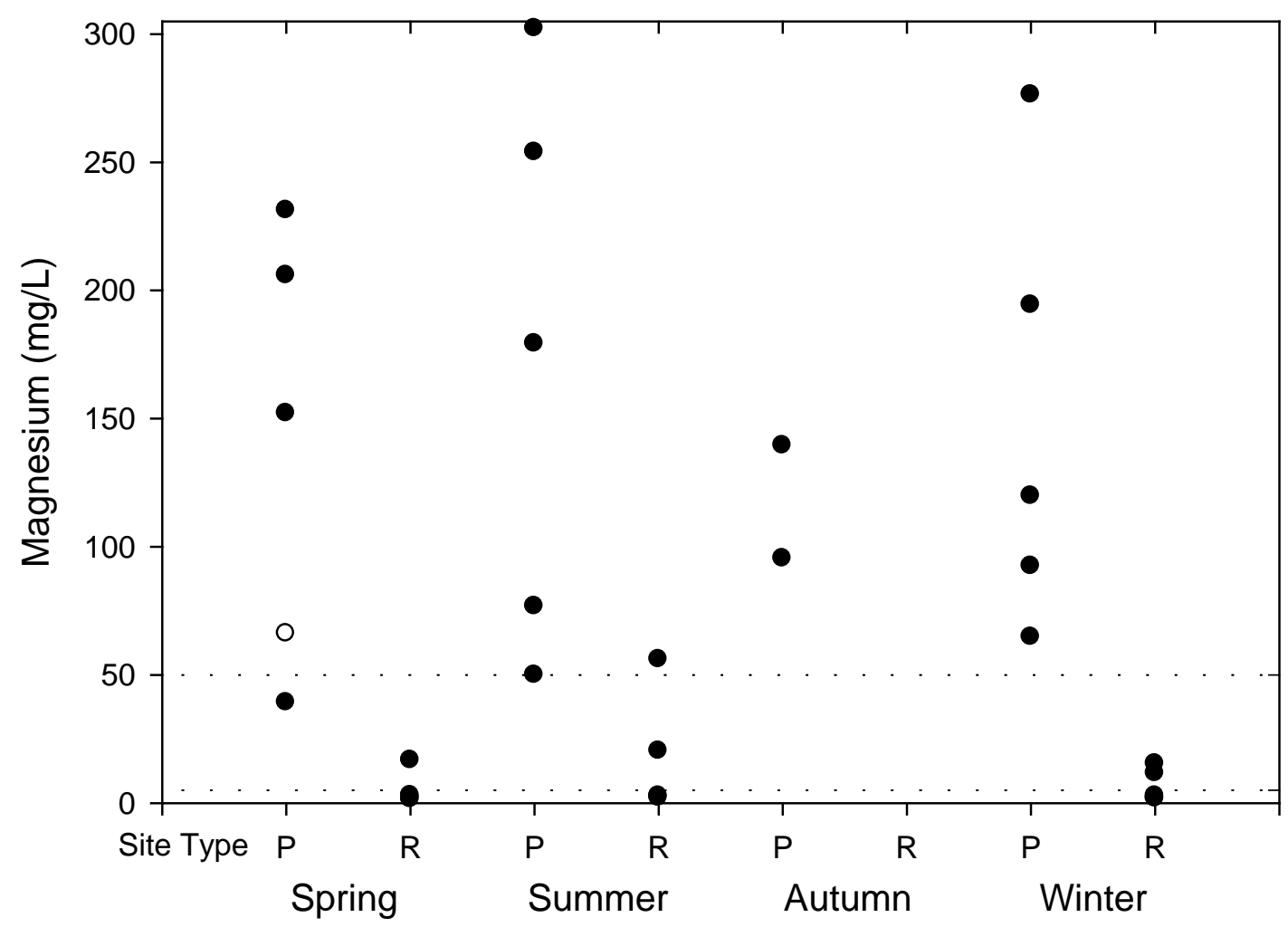

Figure 21. Seasonal magnesium (mg/L) for reclaimed mine perimeter channels and reference streams combined by site type. Streams with magnesium sources usually have levels of 5-50 mg/L (dashed lines). Reference sites did not contain enough water for sampling in autumn. 


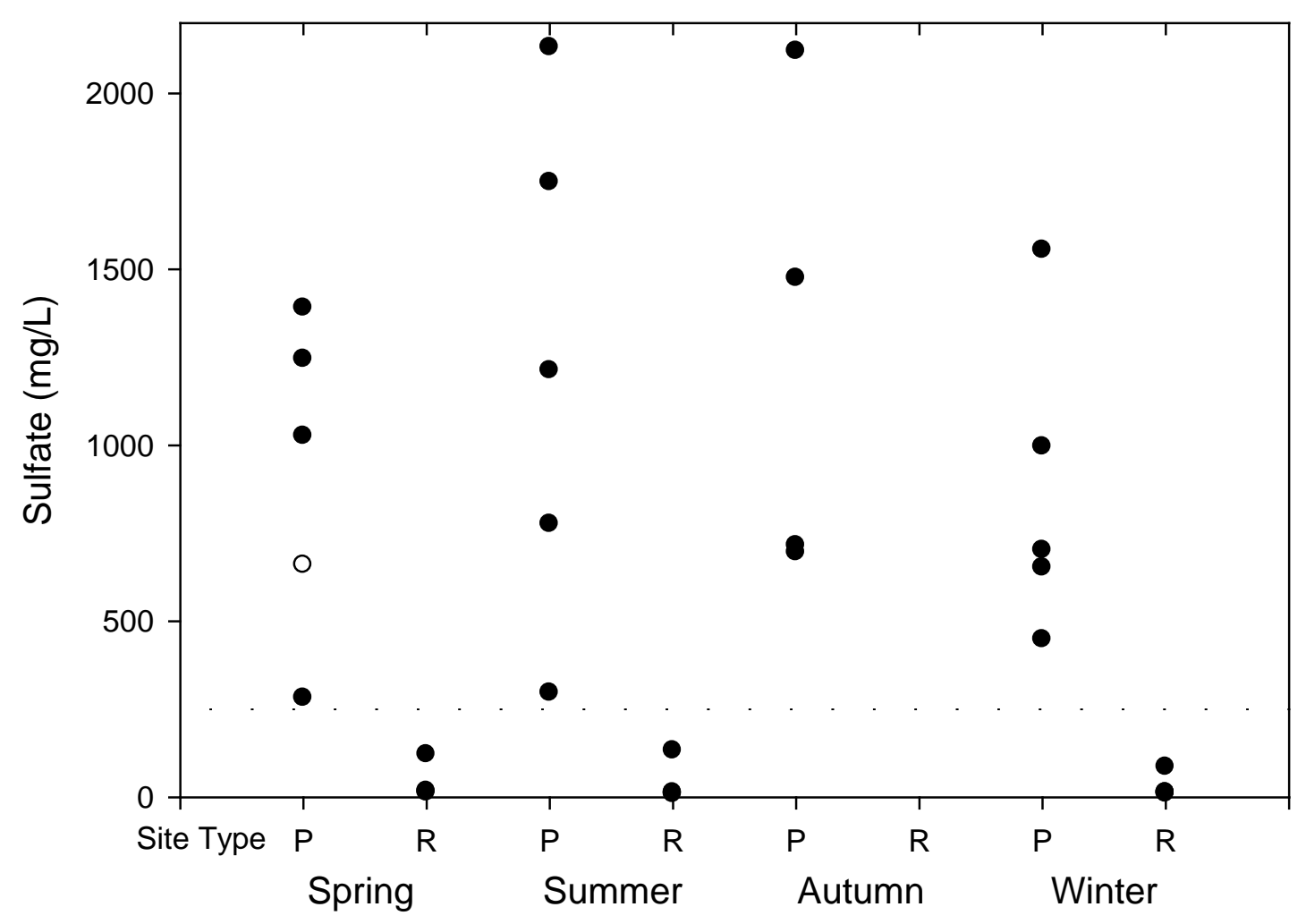

Figure 22. Seasonal sulfate $(\mathrm{mg} / \mathrm{L})$ for reclaimed mine perimeter channels and reference streams combined by site type. Perimeter sites measured above 250 mg/L (dashed line). Reference sites did not contain enough water for sampling in autumn. 


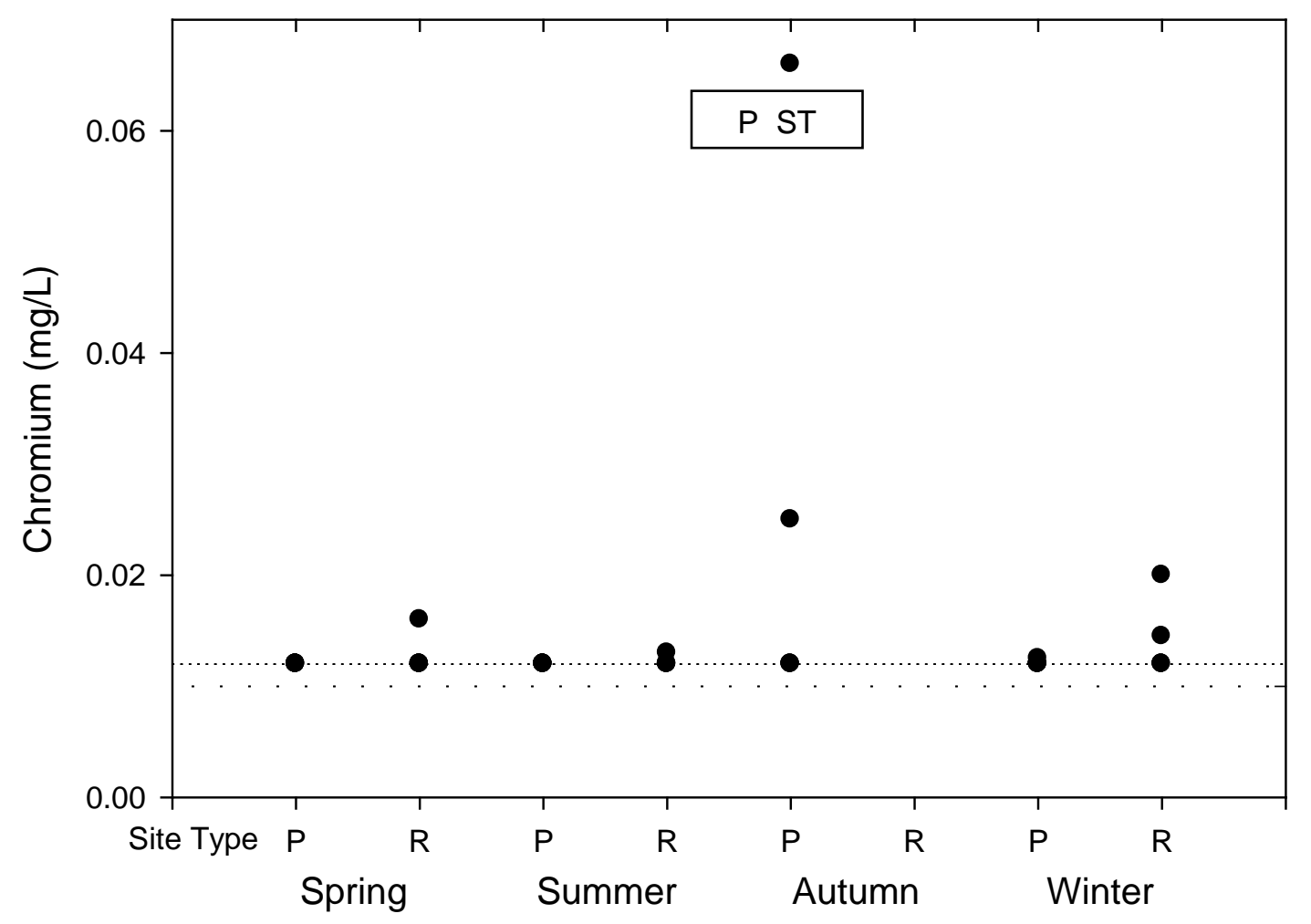

Figure 23. Seasonal chromium (mg/L) for reclaimed mine perimeter channels and reference streams combined by site type. The WWF limit for chromium is $0.01 \mathrm{mg} / \mathrm{L}$ (dashed line). MDL was $0.012 \mathrm{mg} / \mathrm{L}$ (dotted line). Reference sites did not contain enough water for sampling in autumn. 


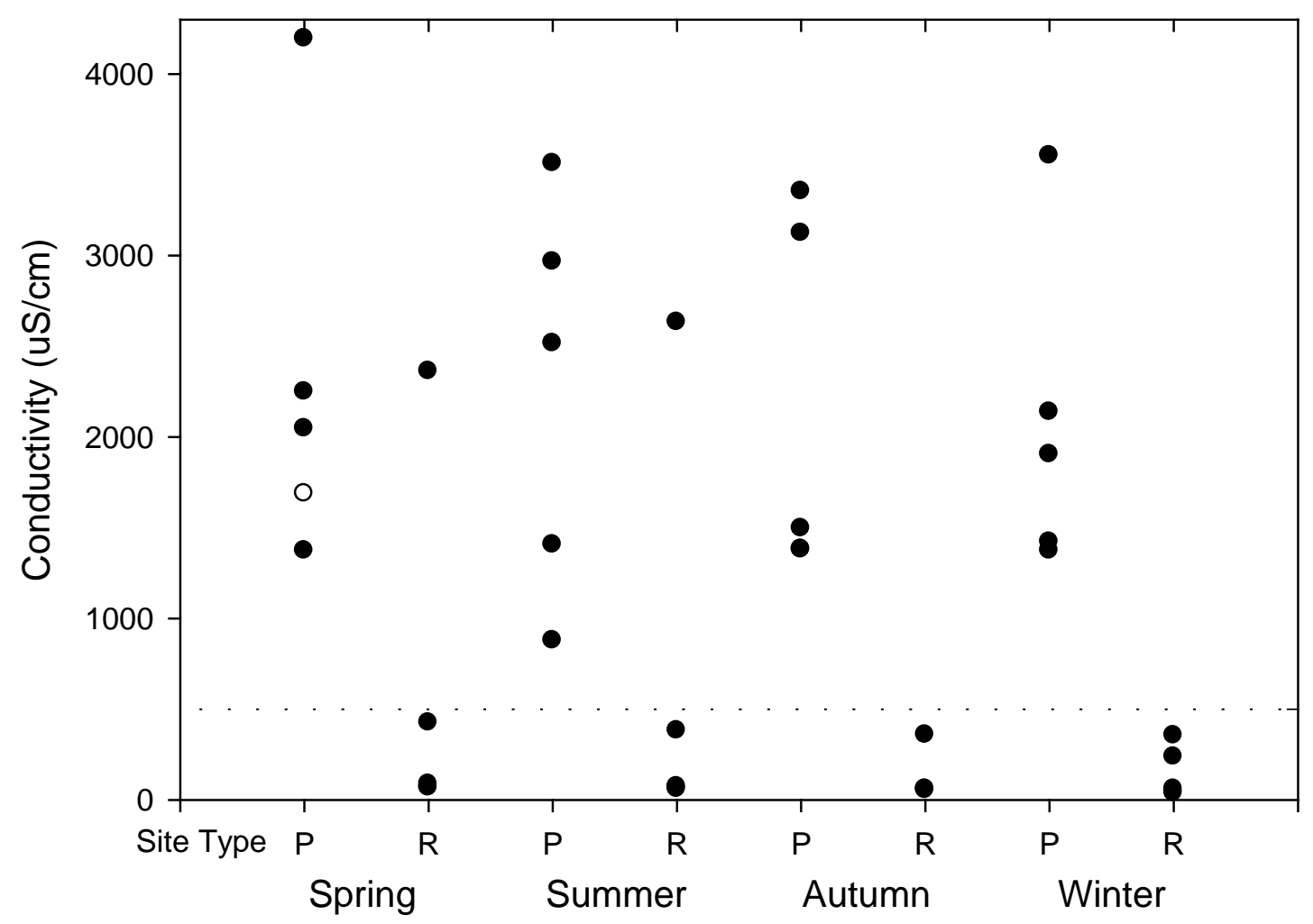

Figure 24. Seasonal conductivity $(\mu \mathrm{S} / \mathrm{cm})$ for reclaimed mine perimeter channels and reference streams combined by site type. A conductivity of $500 \mu \mathrm{S} / \mathrm{cm}$ (dashed line) is the EPA recommended upper limit for healthy fisheries. 


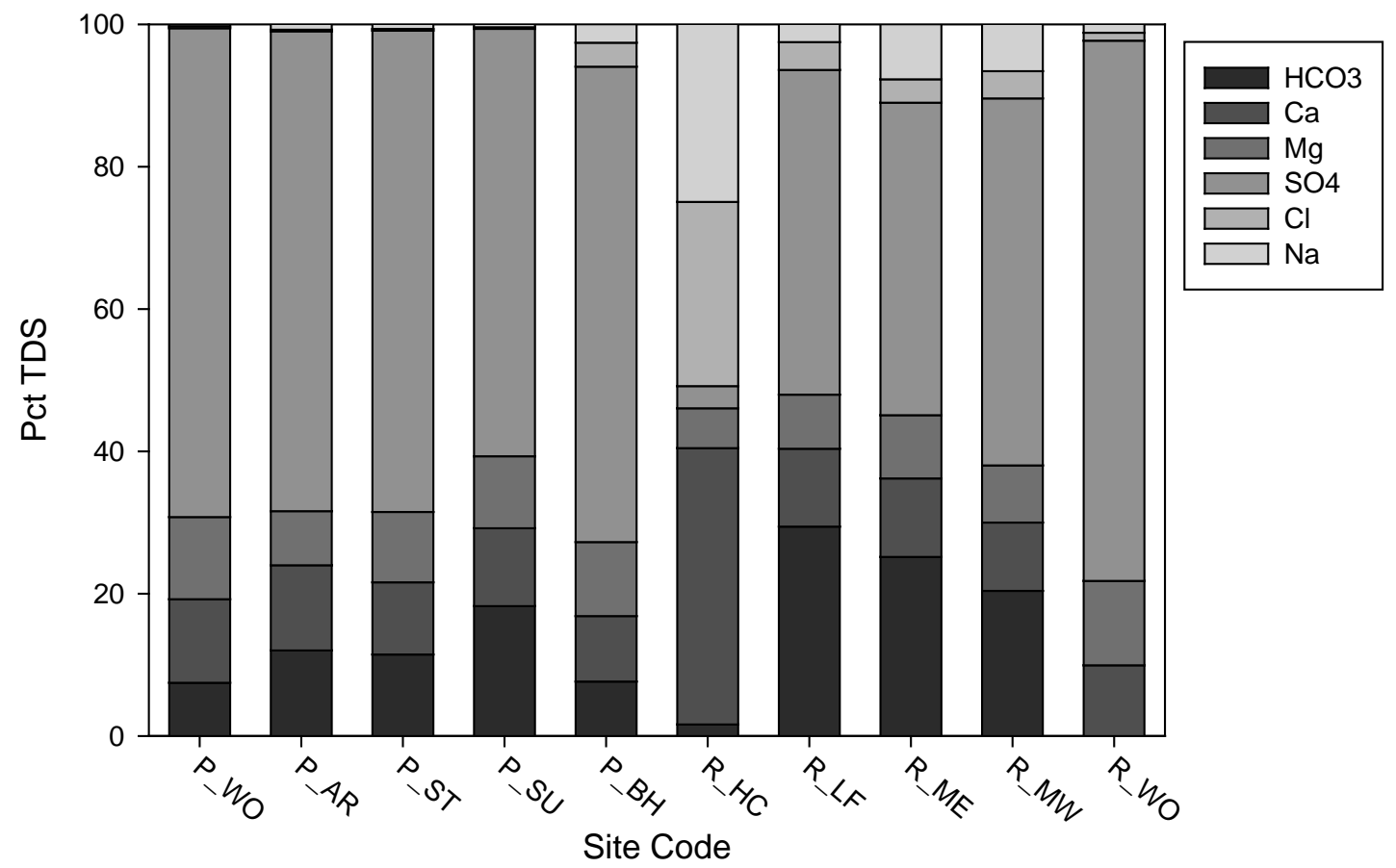

Figure 25. The percent of mean TDS that was composed of bicarbonate, calcium, magnesium, sulfate, chloride, and sodium for reclaimed surface mine perimeter channel and reference sites. Perimeter channels are presented in order of age since reclamation. 




Figure 26. Seasonal aluminum (mg/L) for reclaimed mine perimeter channels and reference streams combined by site type. The WWF limit is $0.75 \mathrm{mg} / \mathrm{L}$ (dashed line). Method detection limits (MDL) were $0.021 \mathrm{mg} / \mathrm{L}$ (dotted line). Reference sites did not contain enough water for sampling in autumn. 




Figure 27. Seasonal nickel (mg/L) for reclaimed mine perimeter channels and reference streams combined by site type. Method detection limit (MDL) was $0.019 \mathrm{mg} / \mathrm{L}$ (dotted line). The WWF limit is $0.088 \mathrm{mg} / \mathrm{L}$ (dashed line). Reference sites did not contain enough water for sampling in autumn. 


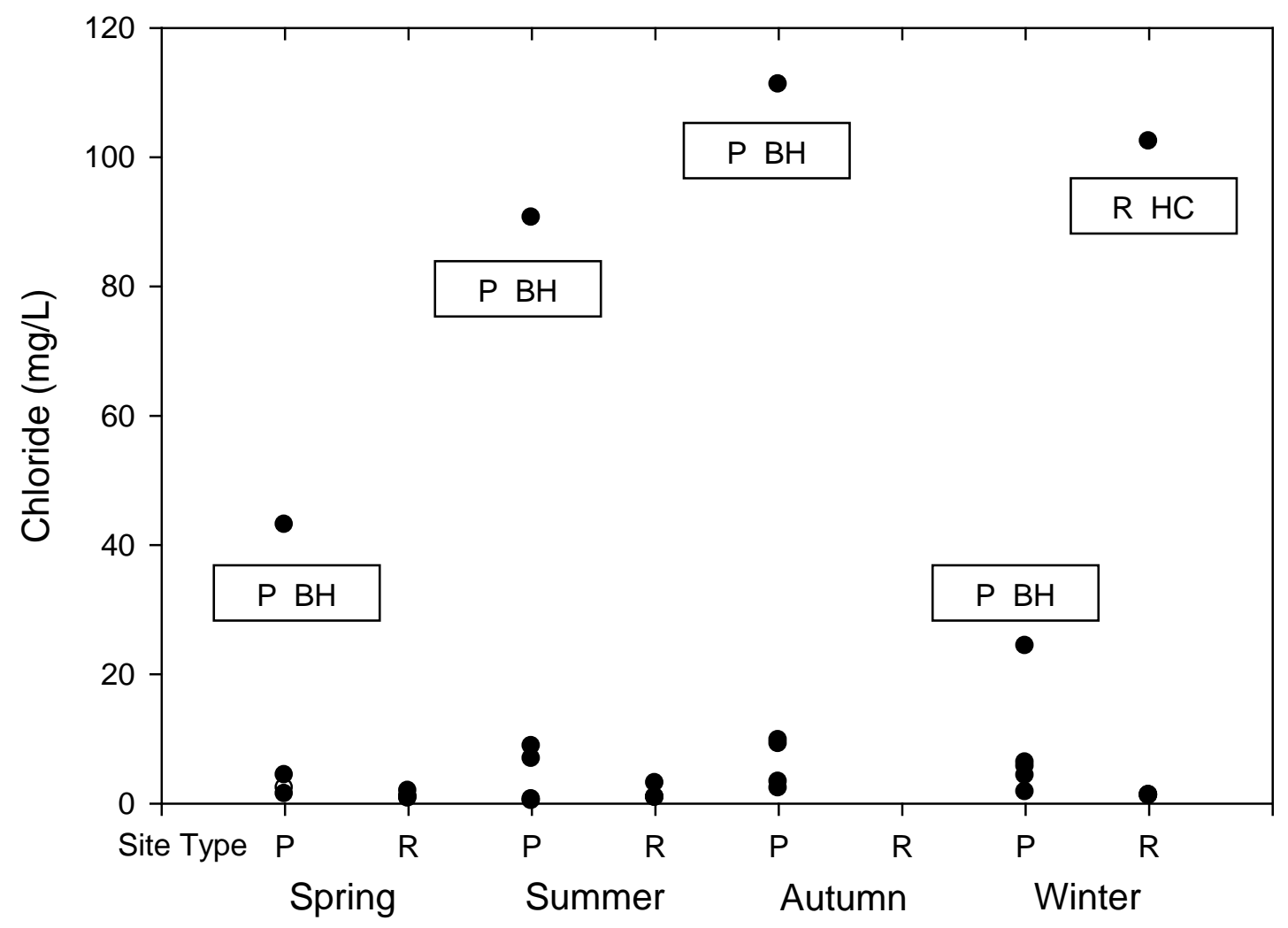

Figure 28. Seasonal chloride (mg/L) for reclaimed mine perimeter channels and reference streams combined by site type. Recommended limit for the protection of aquatic life is $600 \mathrm{mg} / \mathrm{L}$. R_HC experienced a summer measure of $1070.73 \mathrm{mg} / \mathrm{L}$ (not shown) after disturbance. Reference sites did not contain enough water for sampling in autumn. 


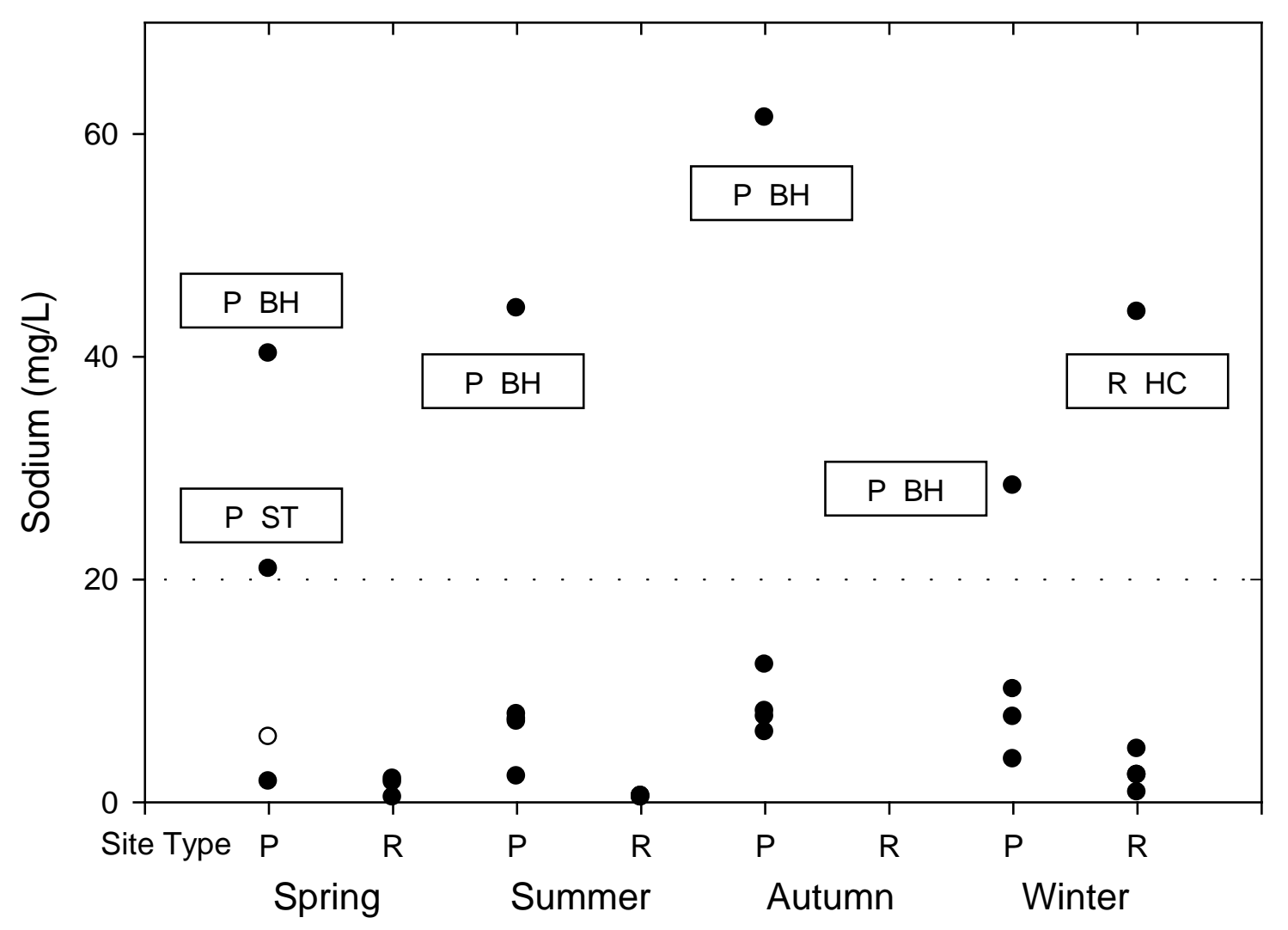

Figure 29. Seasonal sodium (mg/L) for reclaimed mine perimeter channels and reference streams combined by site type. Perimeter channels measured above $20 \mathrm{mg} / \mathrm{L}$ (dashed line). Summer R_HC measured $293.22 \mathrm{mg} / \mathrm{L}$ (not shown). Reference sites did not contain enough water for sampling in autumn. 


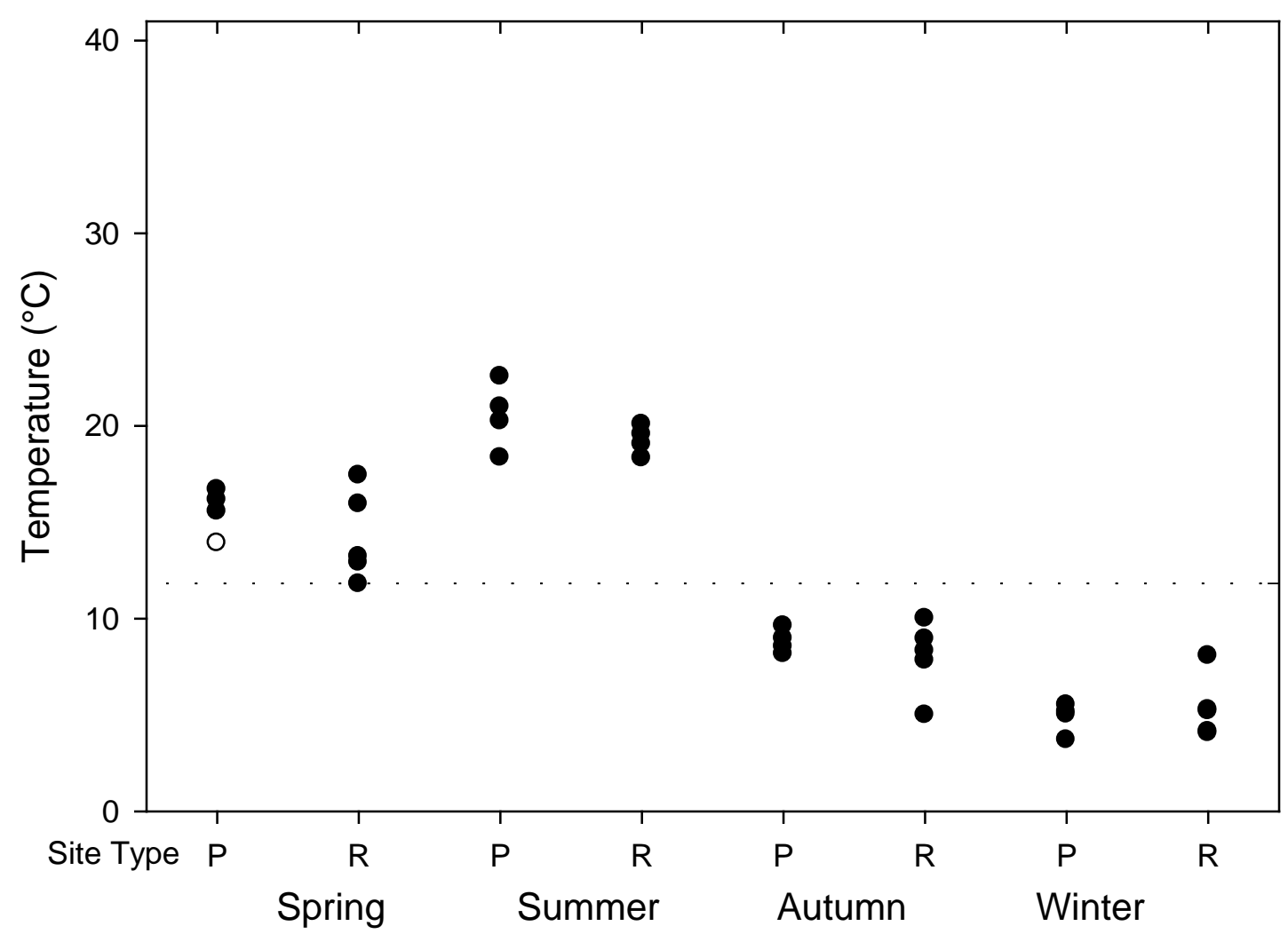

Figure 30. Mean daily temperature for reclaimed mine perimeter channels $(\mathrm{P})$ and reference sites $(\mathrm{R})$ during periods when streams contained water. The mean of these temperatures is $11.7^{\circ} \mathrm{C}$ (dashed line). 




Figure 31. Maximum daily temperature for reclaimed mine perimeter channels $(\mathrm{P})$ and reference sites $(\mathrm{R})$ during periods when streams contained water. The mean of these temperatures is $22.9^{\circ} \mathrm{C}$ (dashed line). 


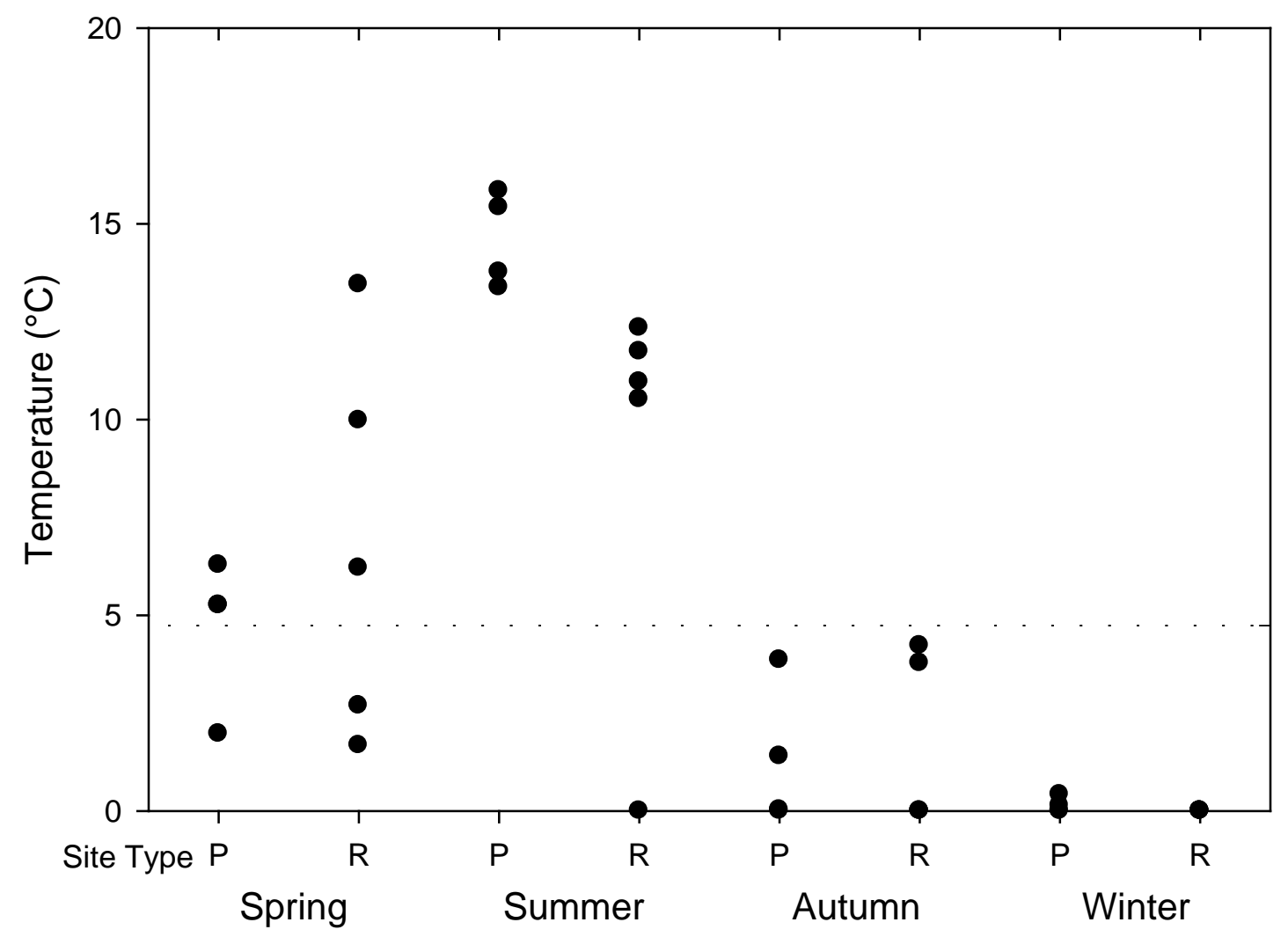

Figure 32. Minimum daily temperature for reclaimed mine perimeter channels (P) and reference sites $(\mathrm{R})$ during periods when streams contained water. The mean of these temperatures is $4.7^{\circ} \mathrm{C}$ (dashed line). 


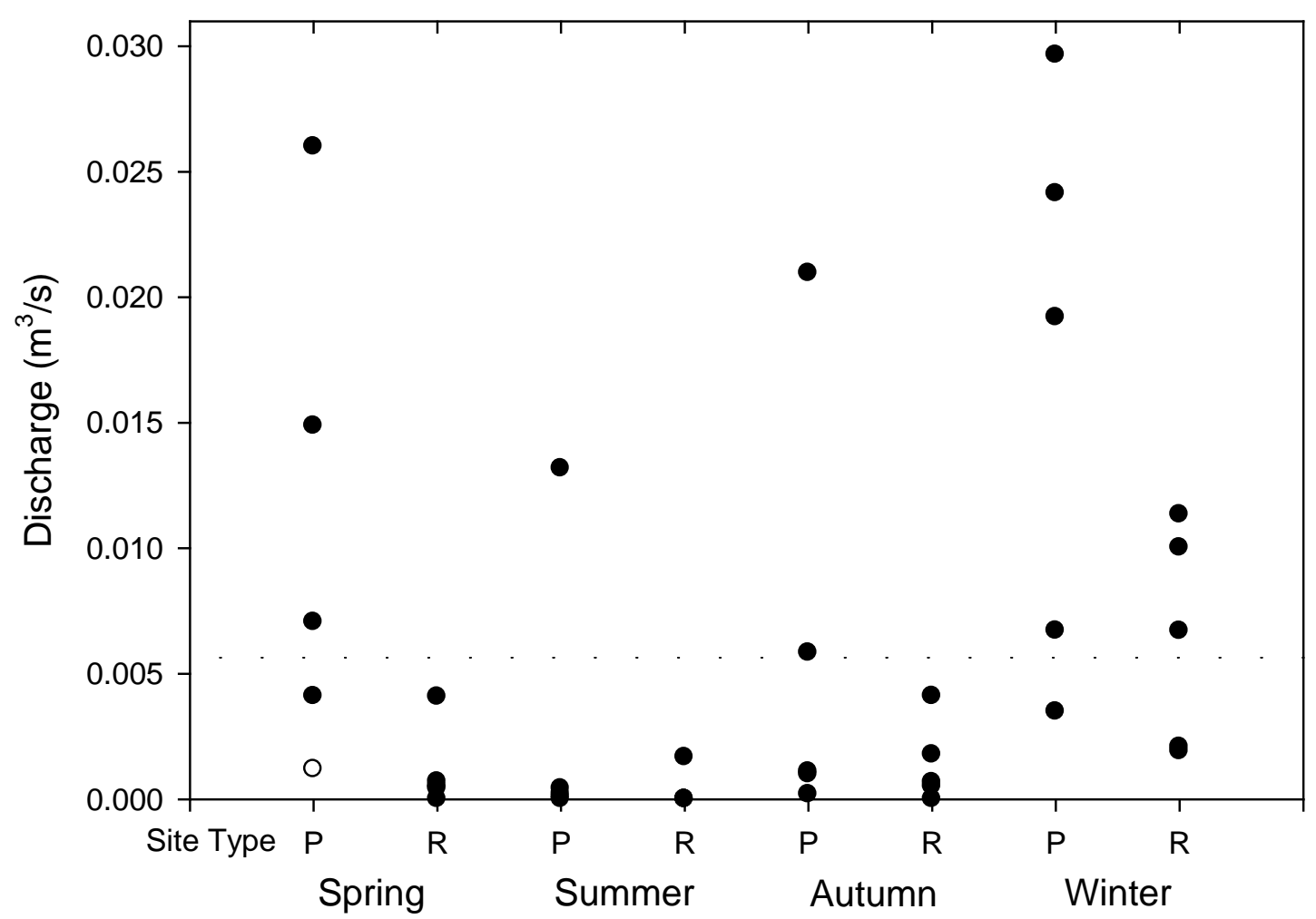

Figure 33. Seasonal discharge $\left(\mathrm{m}^{3} / \mathrm{s}\right)$ for reclaimed mine perimeter channels and reference streams combined by site type. The mean discharge is $0.0057 \mathrm{~m}^{3} / \mathrm{s}$ (dashed line). 




Figure 34. Mean amphibian density and standard error on reclaimed mine perimeter channels and reference sites determined from amphibian abundance surveys performed on four sample dates. Perimeter channel sites are listed in increasing age since reclamation. Perimeter channel sites are shown in black, and reference channel sites are shown in gray. 


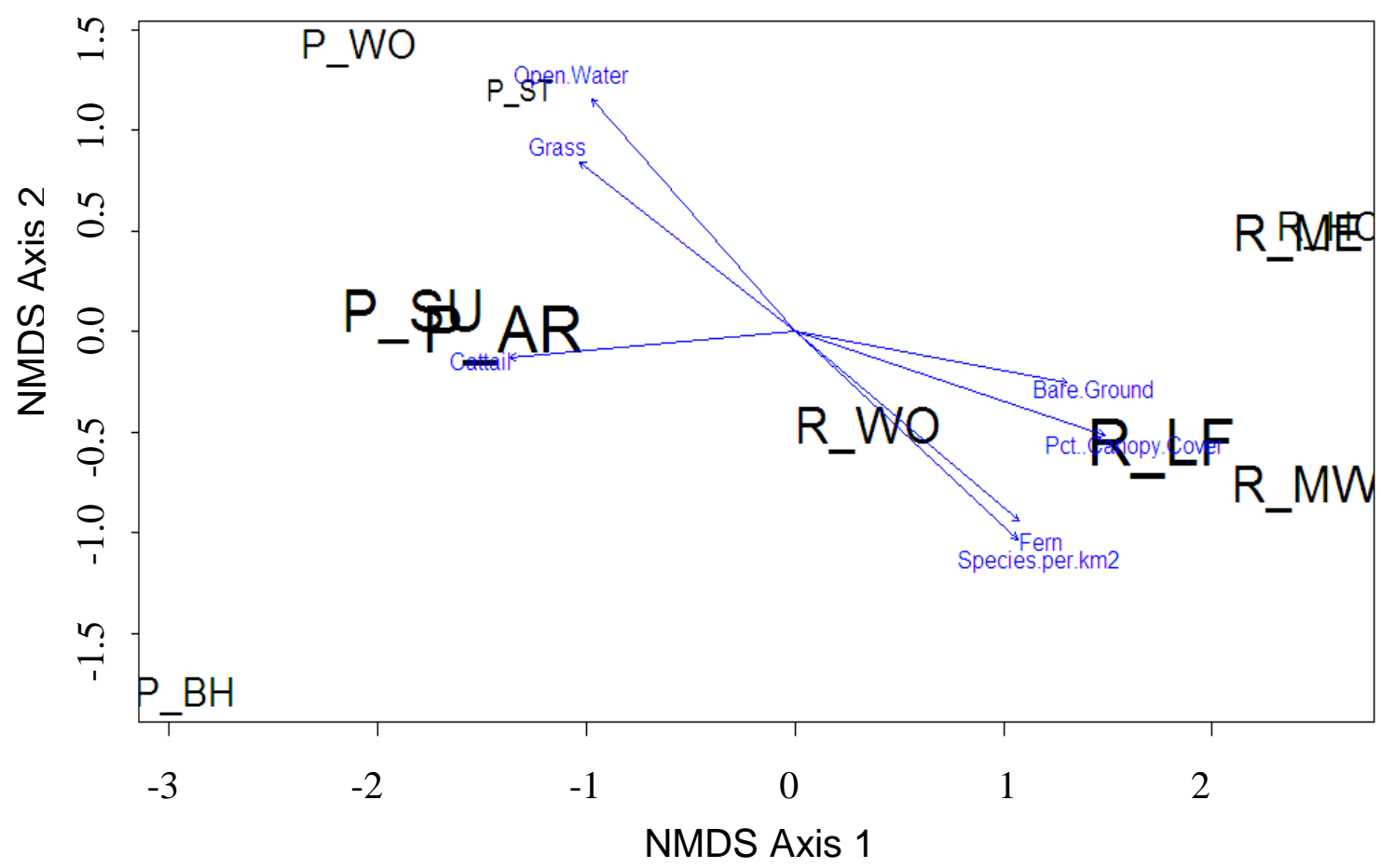

Figure 35. NMDS ordination analysis distinguishing site type by amphibian community data with overlaying significant vegetation vectors. Vegetation vectors include percent open water, grass, cattail, bare ground, percent canopy cover (Pct.Canopy.Cover), fern, and species per $\mathrm{km}^{2}$. The direction of the vector indicates the direction of influence the vector has on determining community composition. The size of the character indicates the species richness of the site with larger characters indicating sites with greater richness. 


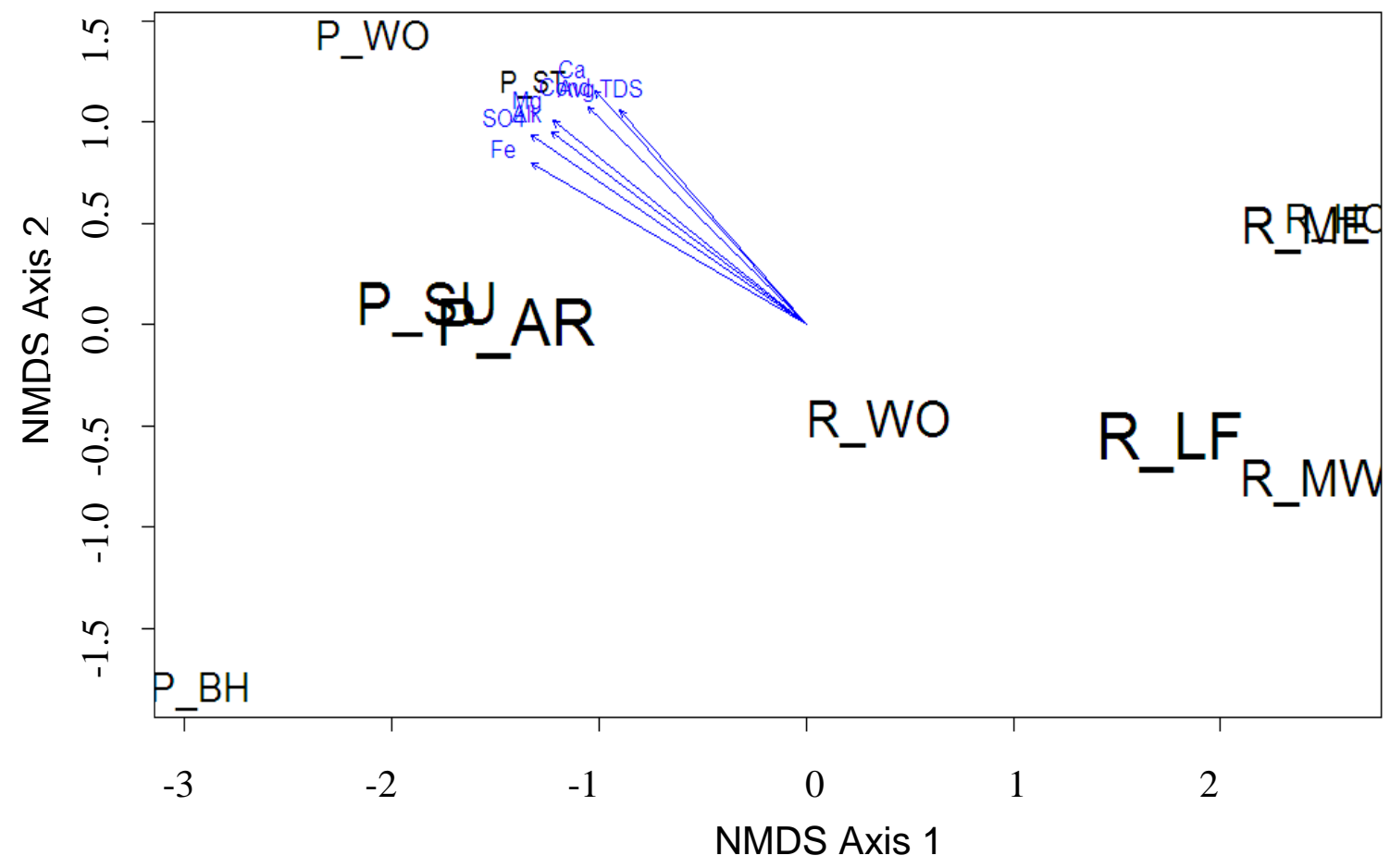

Figure 36. NMDS ordination analysis distinguishing site type by amphibian community data with overlaying significant water chemistry vectors. The direction of the vector indicates the direction of influence the vector has on determining community composition. Vector measures include mean conductivity (Cond), sulfate $\left(\mathrm{SO}_{4}\right)$, magnesium (Mg), mean total dissolved solids (Avg.TDS), calcium (Ca), alkalinity (Alk), and iron $(\mathrm{Fe})$. The size of the character indicates the species richness of the site with larger characters indicating sites with greater richness. 


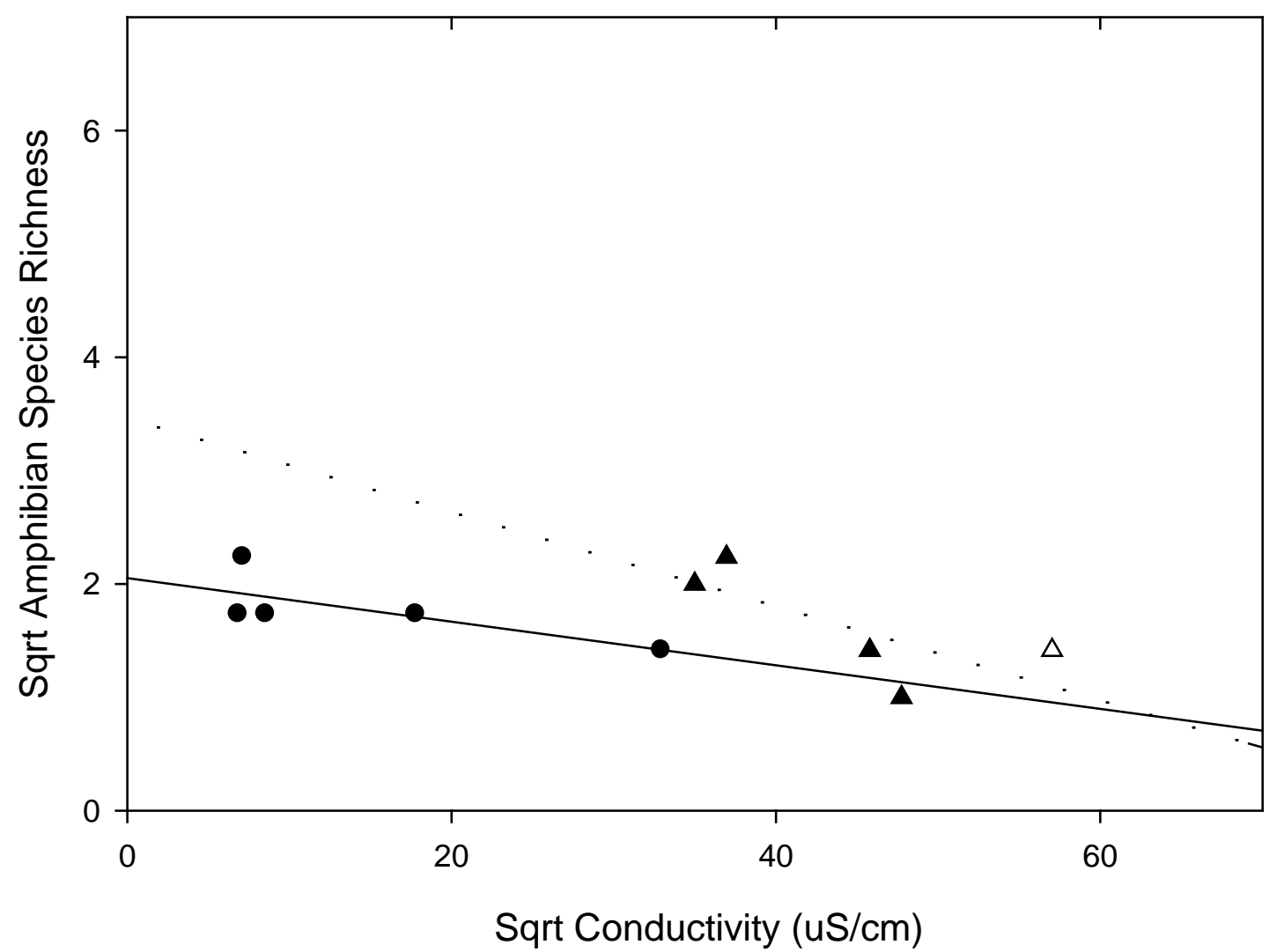

Figure 37. Mean conductivity versus amphibian species richness for four sampling periods. Reclaimed mine perimeter channel sites are represented by black triangles and dotted regression line. Reference sites are represented by black circles and solid regression line. 


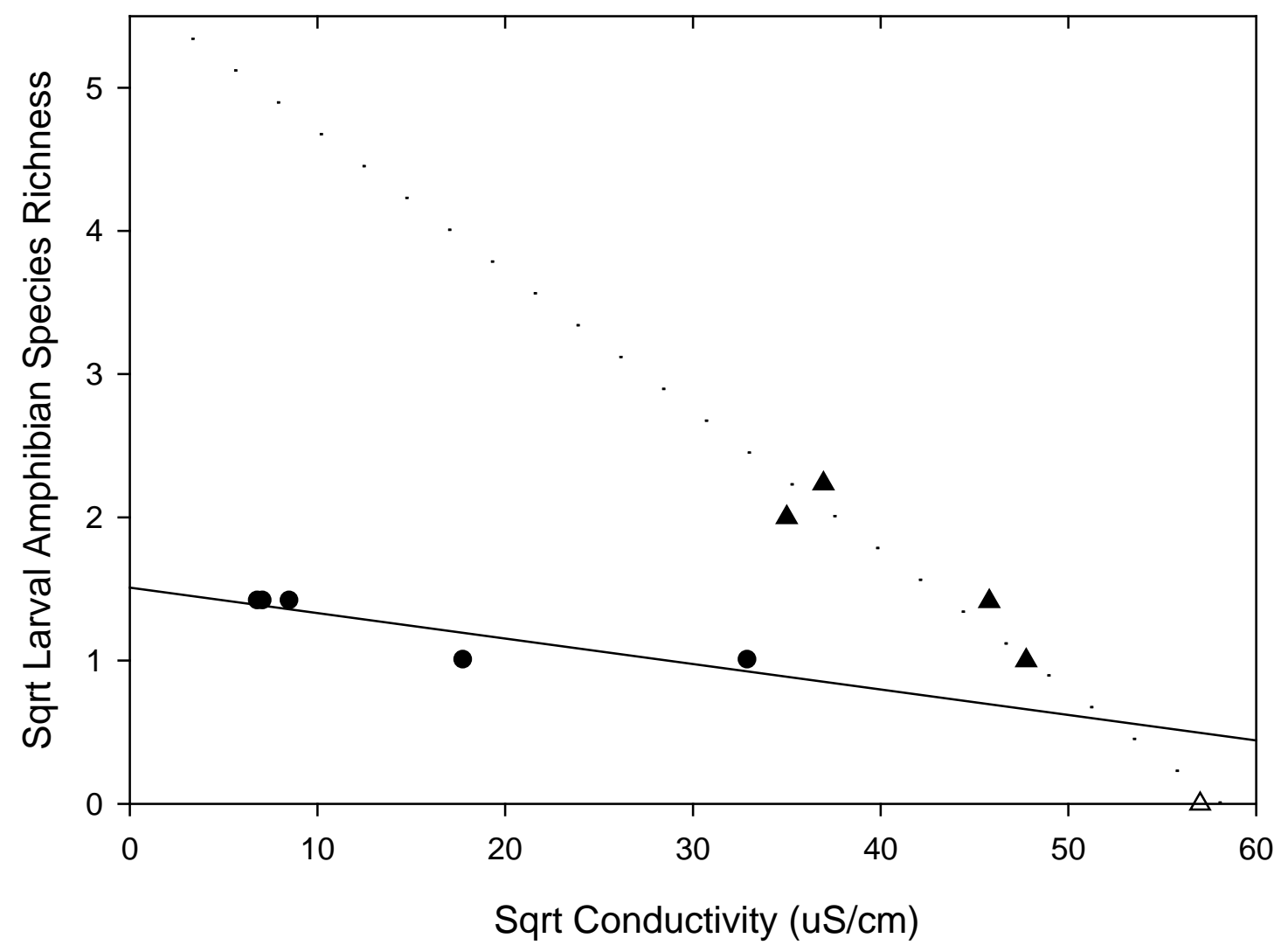

Figure 38. Mean conductivity versus the total number of larval amphibian species for four sampling periods. Reclaimed mine perimeter channel sites are represented by black triangles and dotted regression line. Reference sites are represented by black circles and solid regression line. 




Figure 39. Mean conductivity versus the total number of larval amphibians captured during four amphibian sampling periods. Reclaimed mine perimeter channel sites are represented by black triangles and dotted regression line. Reference sites are represented by black circles and solid regression line. 


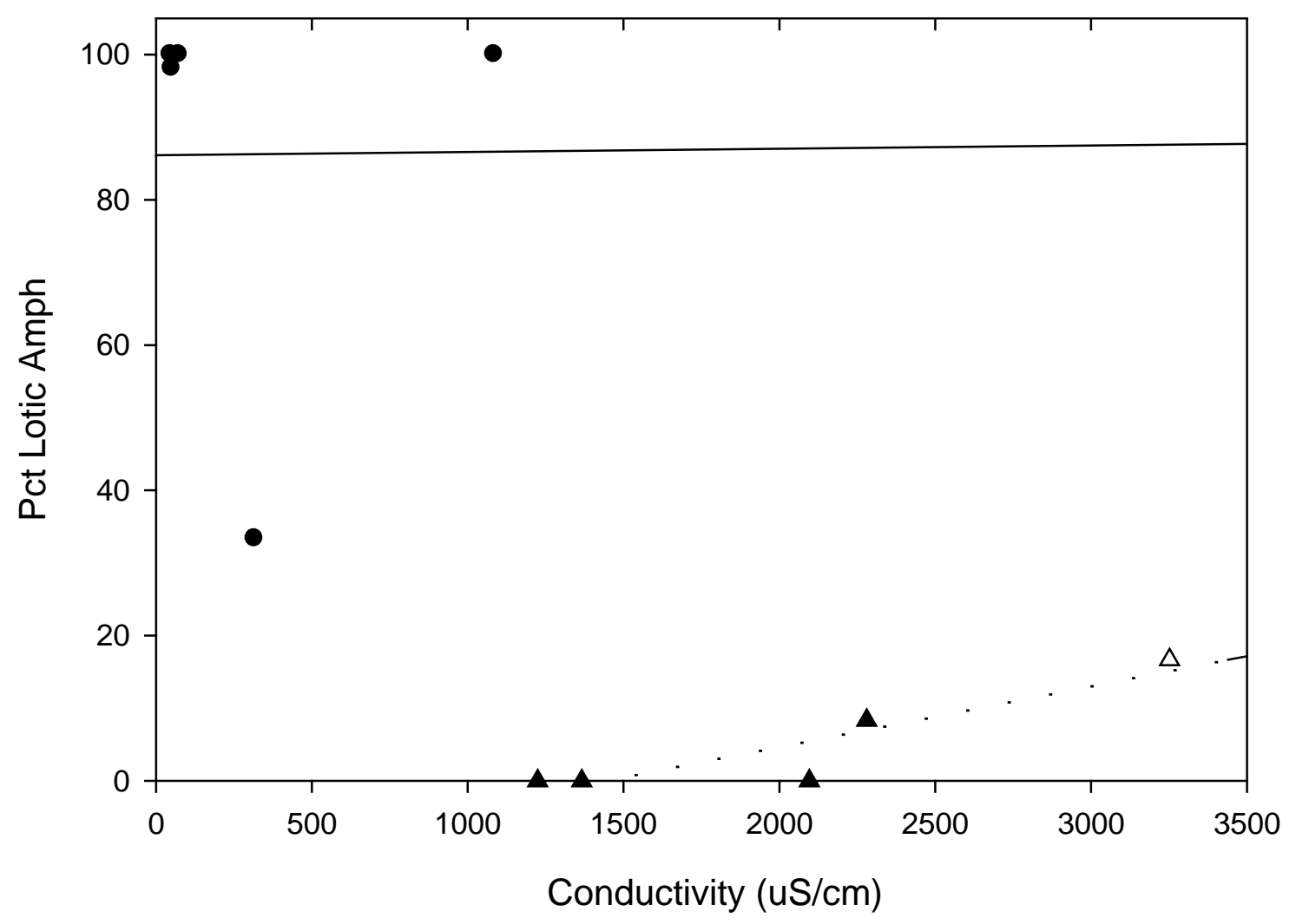

Figure 40. Mean conductivity versus mean percentage of amphibian species present that utilize lotic habitat. Reclaimed mine perimeter channel sites are represented by black triangles and dotted regression line. Reference sites are represented by black circles and solid regression line. 




Figure 41. Mean conductivity versus the percentage of amphibian species present, during four sampling periods, that utilize forest habitat. Reclaimed mine perimeter channel sites are represented by black triangles and dotted regression line. Reference sites are represented by black circles and solid regression line. 


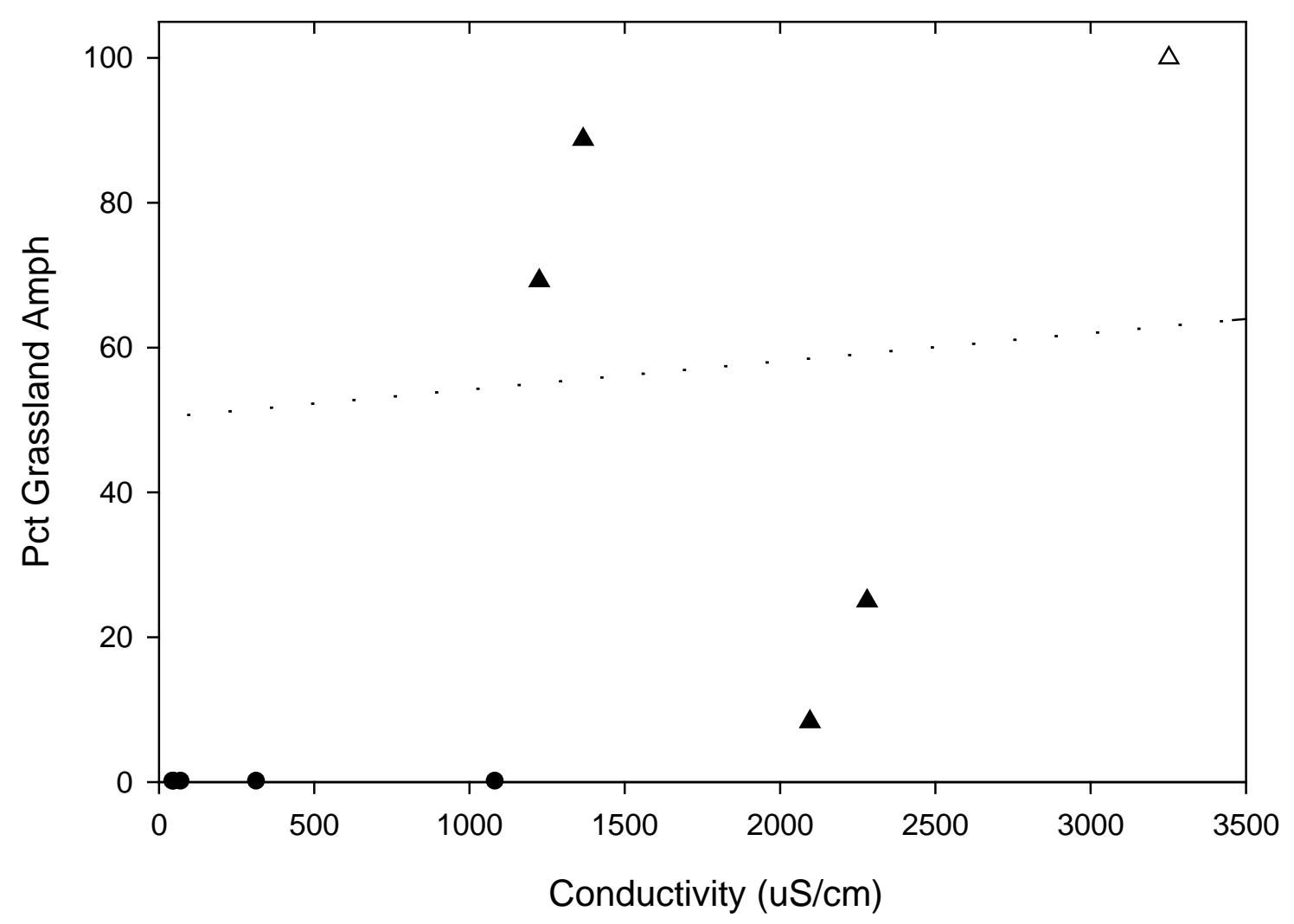

Figure 42. Mean conductivity versus the percentage of amphibian species present that utilize grassland habitat. Reclaimed mine perimeter channel sites are represented by black triangles and dotted regression line. Reference sites are represented by black circles and solid regression line. 


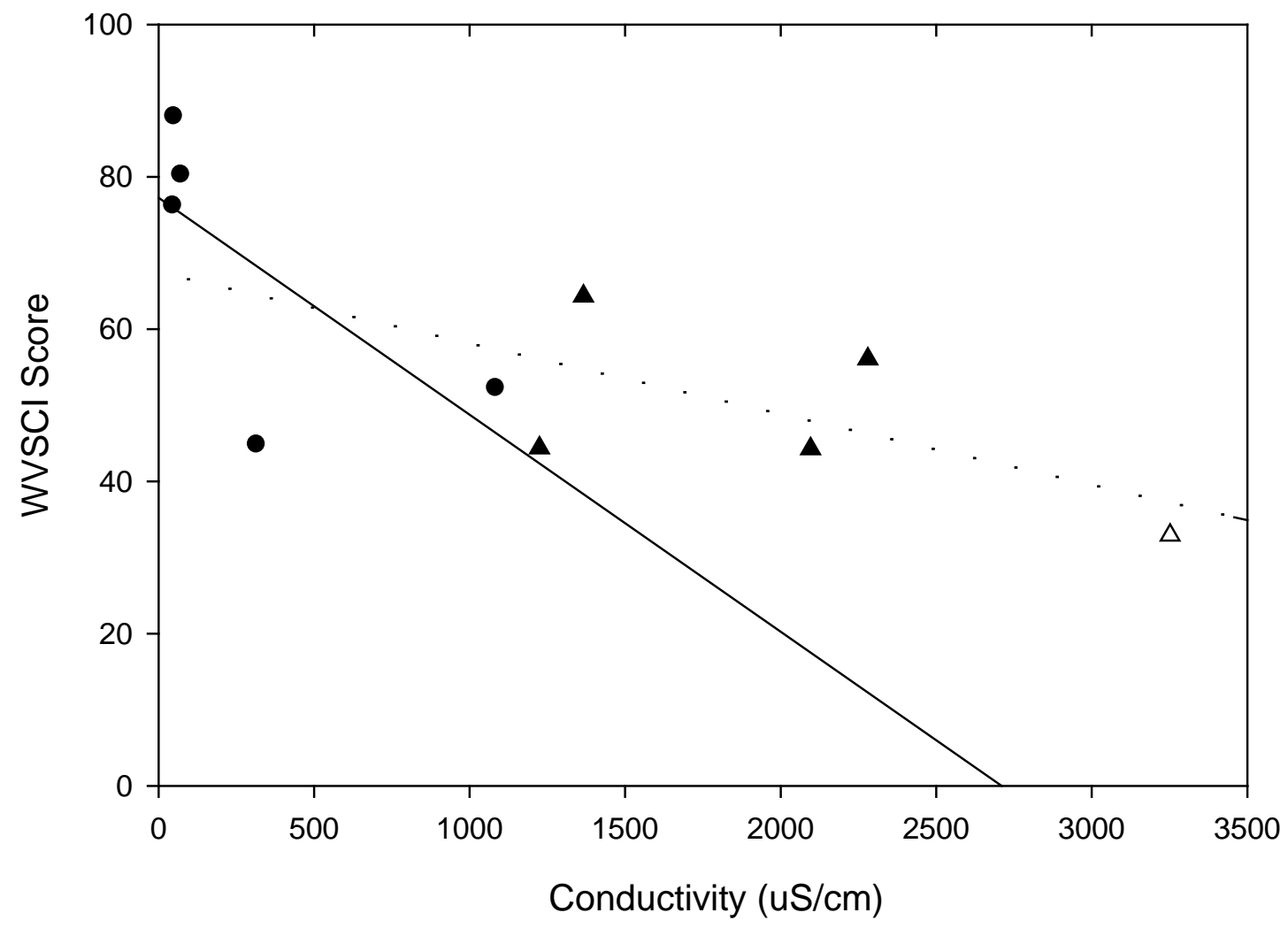

Figure 43. Mean conductivity versus WVSCI score for the spring 2008 sampling period. Reclaimed mine perimeter channel sites are represented by black triangles and dotted regression line. Reference sites are represented by black circles and solid regression line. 


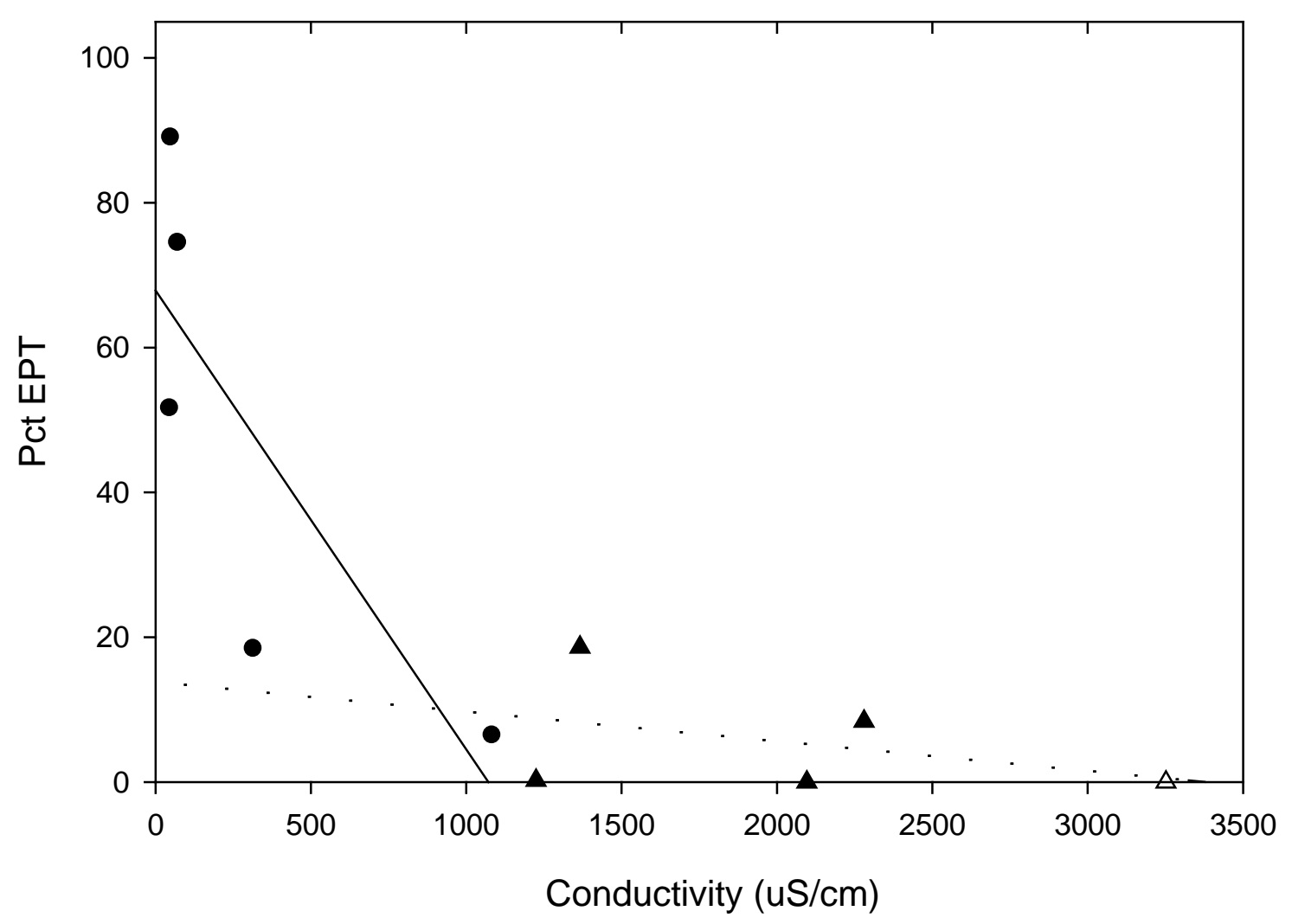

Figure 44. Mean conductivity versus percent EPT for the spring 2008 sampling period. Reclaimed mine perimeter channel sites are represented by black triangles and dotted regression line. Reference sites are represented by black circles and solid regression line. 




Figure 45. Mean conductivity versus EPT species richness for the spring 2008 sampling period. Reclaimed mine perimeter channel sites are represented by black triangles and dotted regression line. Reference sites are represented by black circles and solid regression line. 


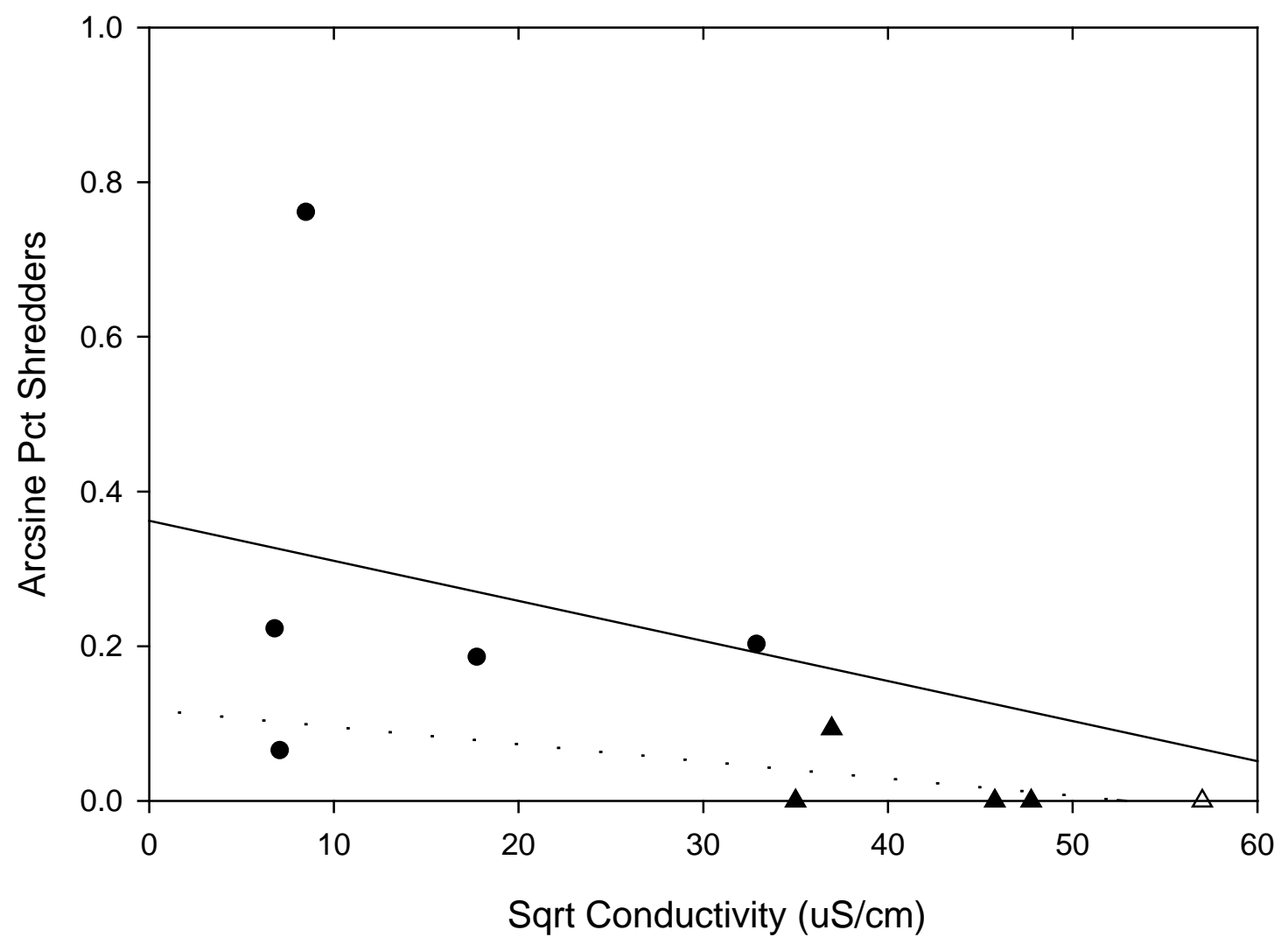

Figure 46. Mean conductivity versus percentage of shredders for the spring 2008 sampling period. Reclaimed mine perimeter channel sites are represented by black triangles and dotted regression line. Reference sites are represented by black circles and solid regression line 


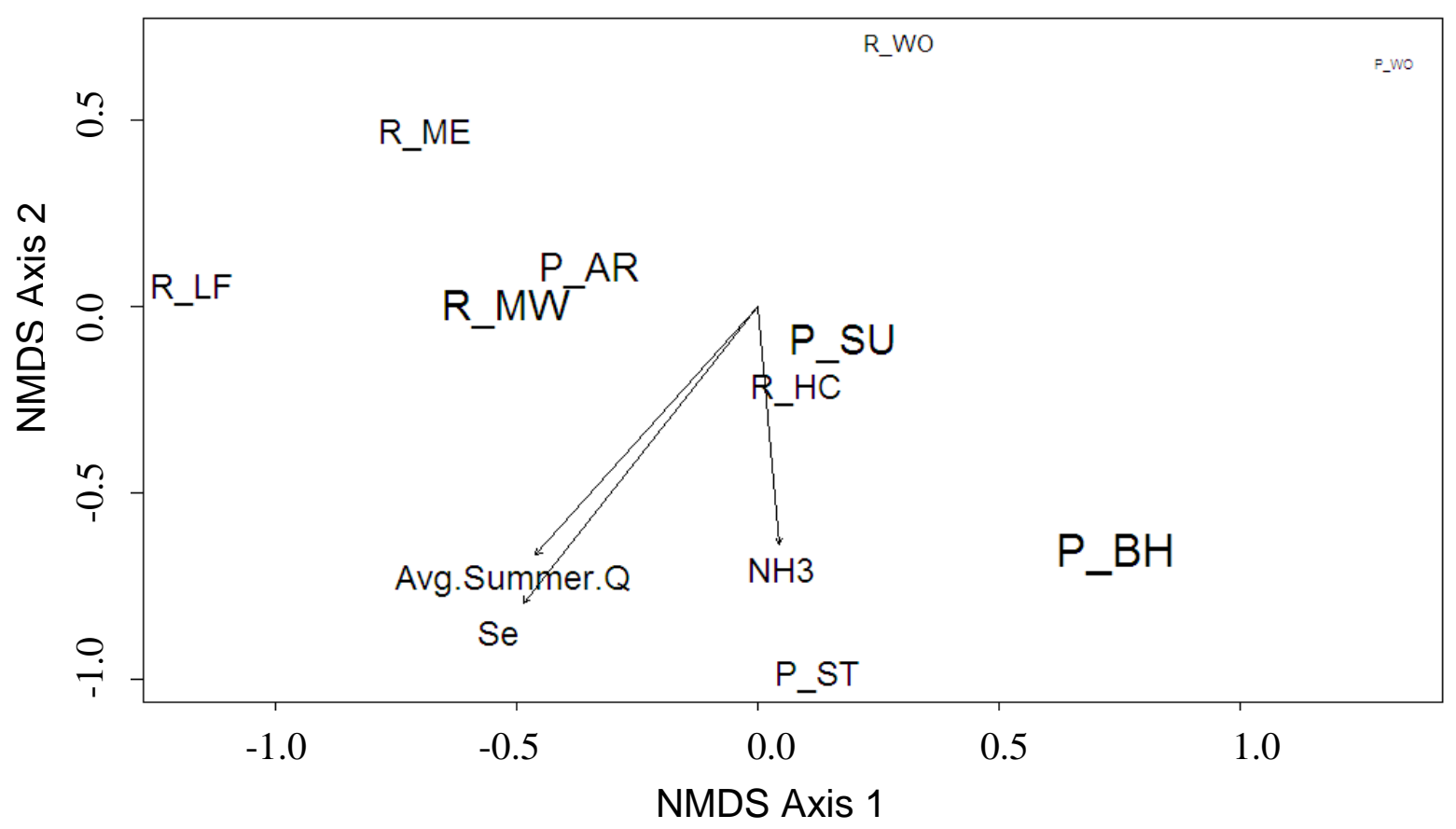

Figure 47. NMDS ordination analysis distinguishing site type by macroinvertebrate community data with overlaying significant environmental vectors. The direction of the vector indicates the direction of influence the vector has on determining community composition. Vector measures include $\mathrm{NH}_{3}$, mean summer discharge (Avg.Summer.Q), and selenium (Se). The size of the site character indicates the family richness of the site with larger characters indicating sites with greater richness. 


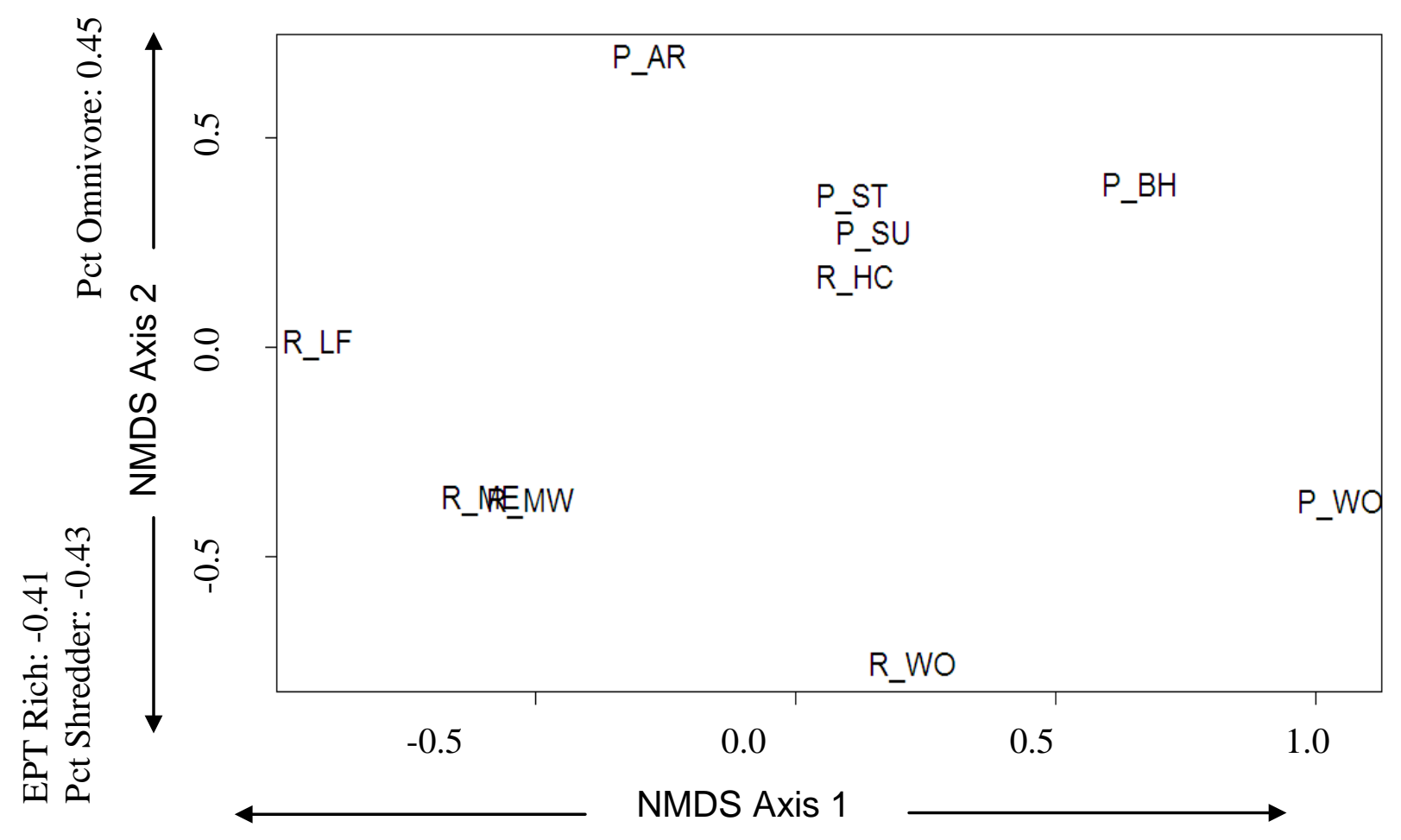

WVSCI: -0.60

Pct Tolerant: 0.64

Pct EPT: -0.59

EPT Rich: -0.61

Pct Unknown: -0.59

Figure 48. NMDS ordination analysis distinguishing site type by macroinvertebrate community data with Spearman rank correlations are annotated along each axis. The size of the site character indicates the species richness of the site with larger characters indicating sites with greater richness. 


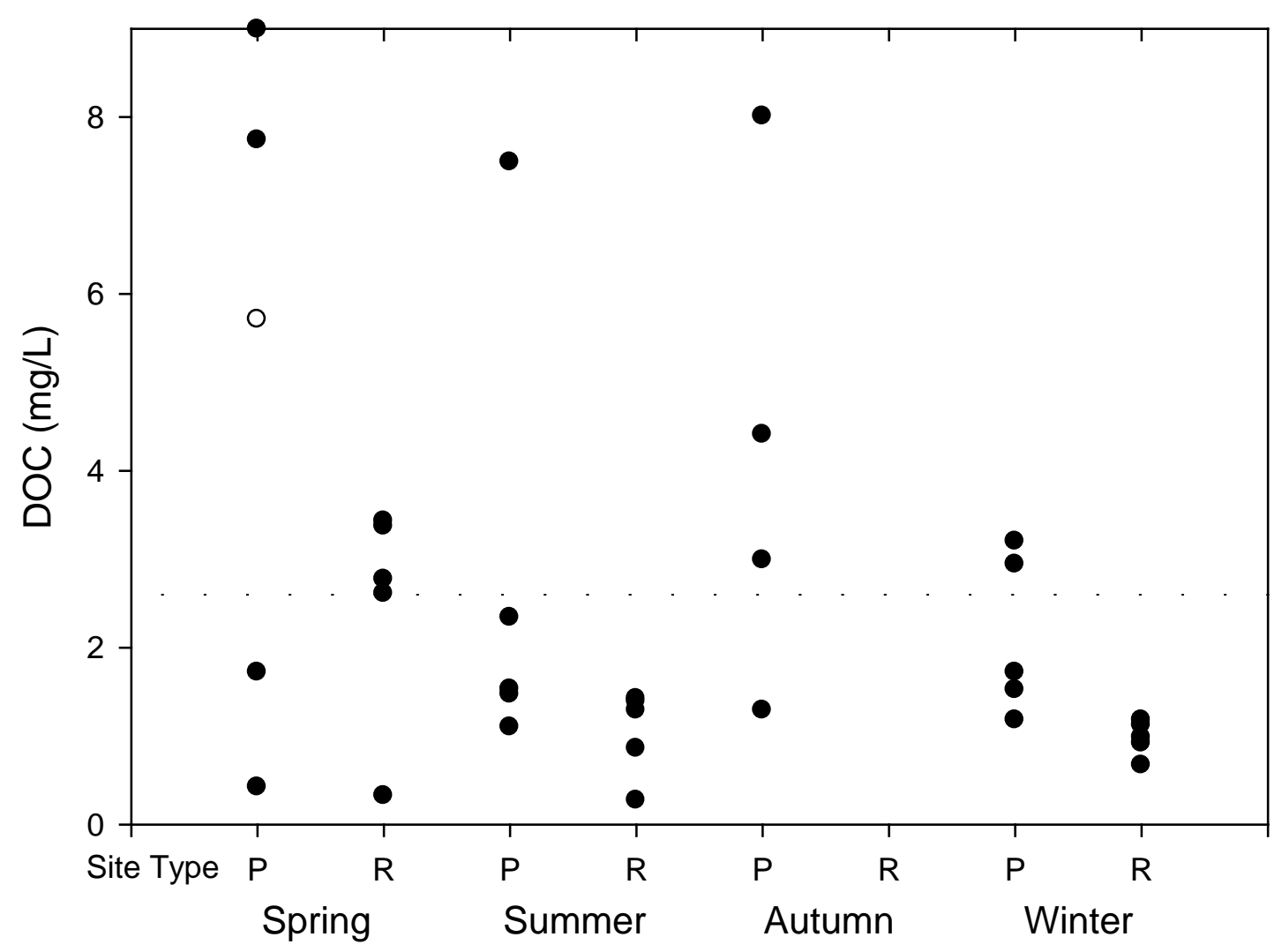

Figure 49. Seasonal DOC measurements for reclaimed mine perimeter channels and reference sites combined by site type. Mean DOC is $2.60 \mathrm{mg} / \mathrm{L}$ (dashed line). Reference sites did not contain enough water for autumn sampling. 


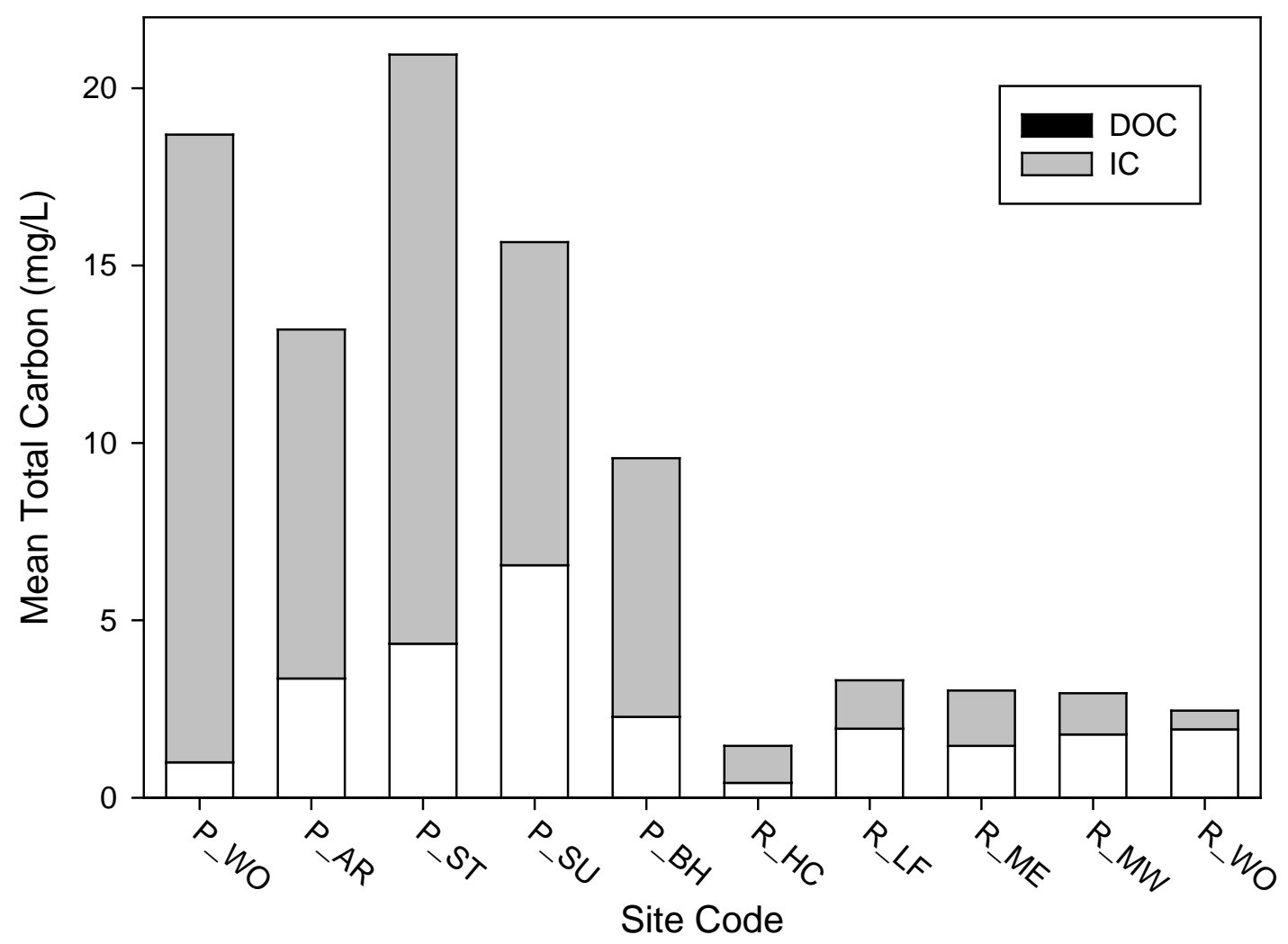

Figure 50. Mean total carbon for reclaimed mine perimeter channels and reference sites given by concentration of dissolved organic carbon (DOC) and inorganic carbon (IC). Perimeter channel sites are listed in increasing age since reclamation. 


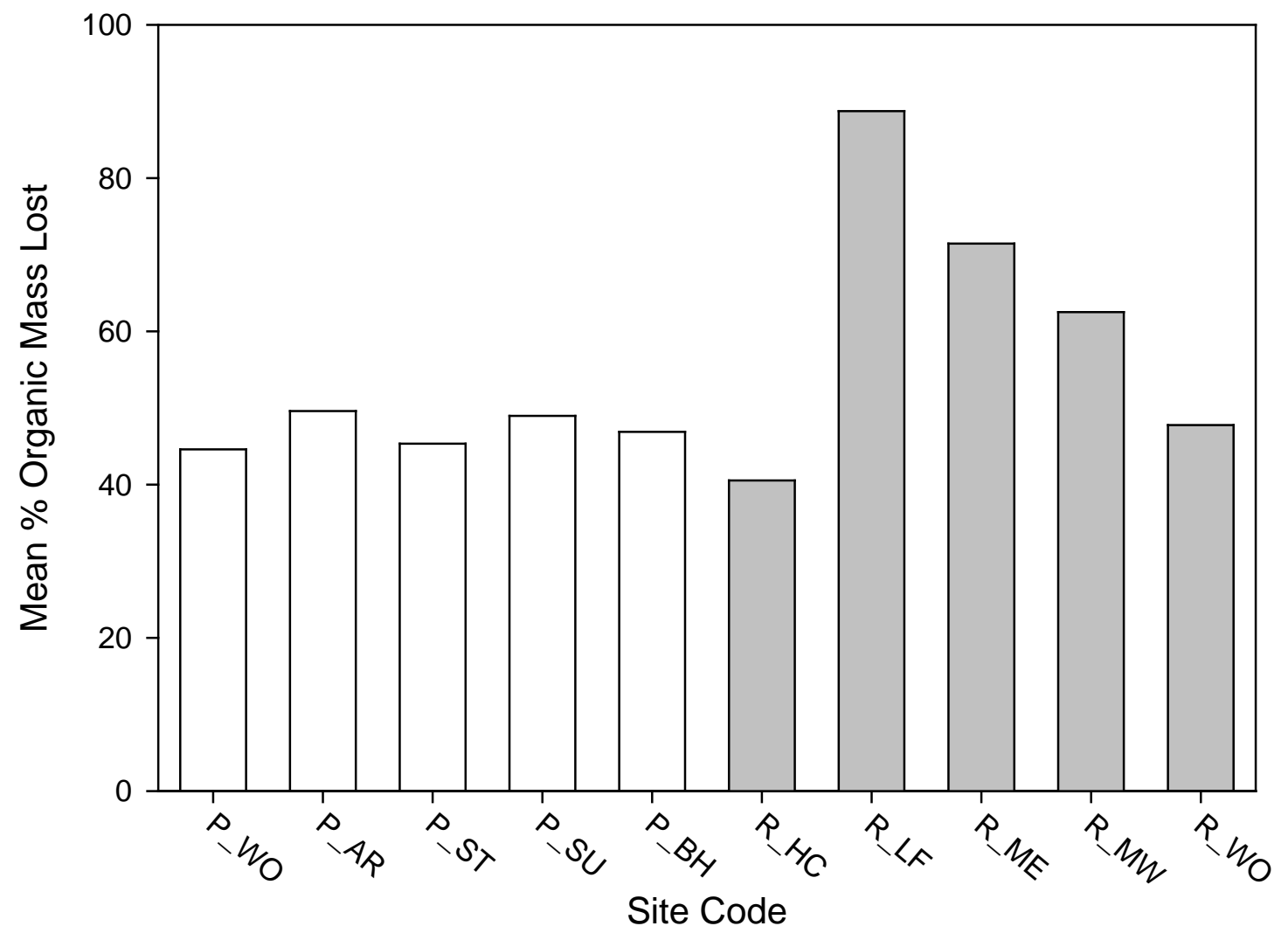

Figure 51. Mean percent organic mass lost from original leaf litter inputs after $~ 325$ days of exposure on reclaimed mine perimeter channels and reference sites. Perimeter channel sites are listed in order of increasing age since reclamation. Perimeter channel sites are shown in black and reference channel sites are shown in gray. 




Figure 52. Decomposition rate (-k) of Quercus palustris (pin oak) leaf litter on reclaimed mine perimeter channels and reference streams after $\sim 325$ days of exposure. Perimeter channel sites are listed in increasing age since reclamation. Perimeter channel sites are shown in black and reference channel sites are shown in gray. 


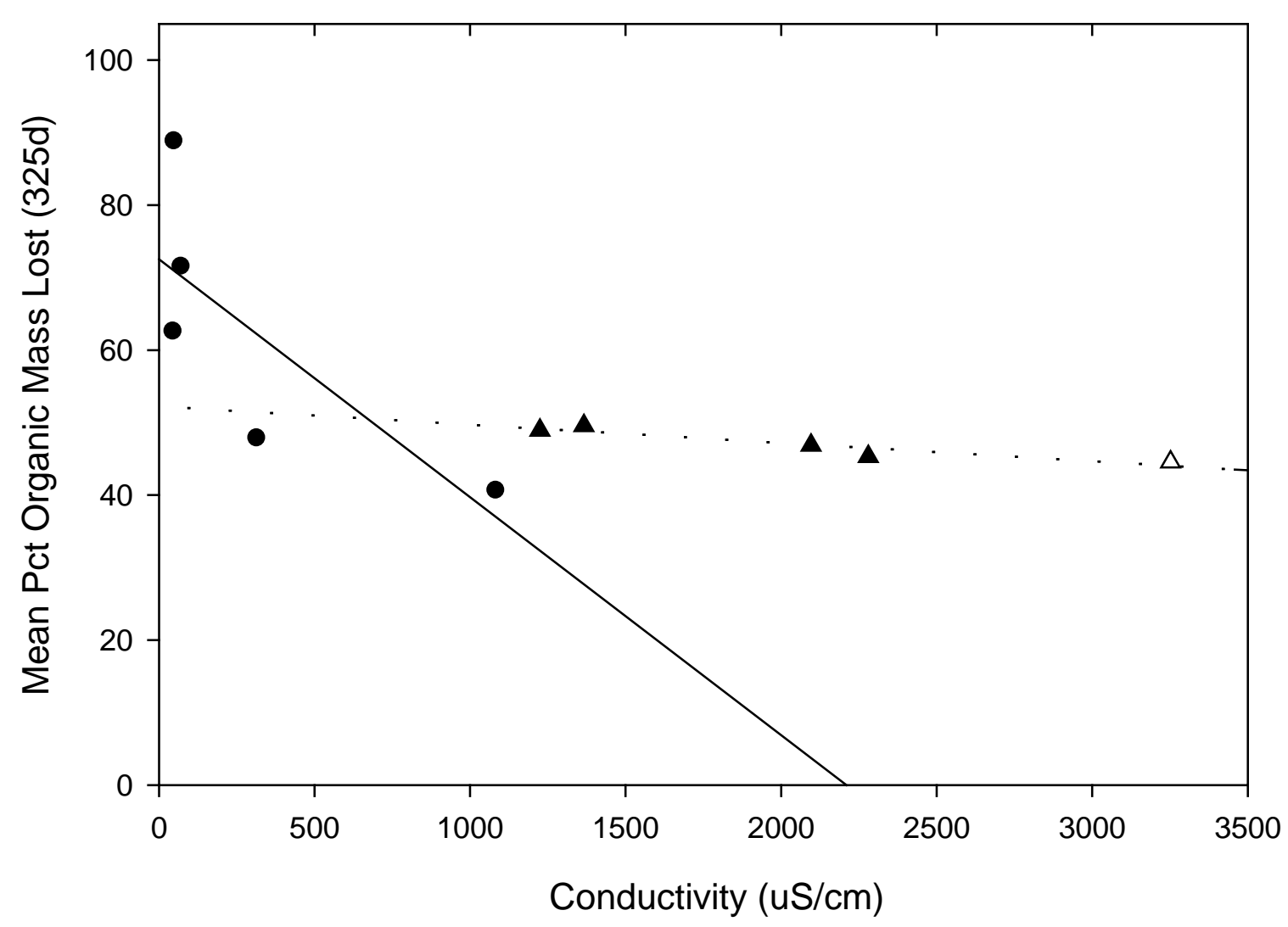

Figure 53. Mean conductivity versus mean percent organic mass lost from leaf litter packs after 325 days. Reclaimed mine perimeter channel sites are represented by black triangles and dotted regression line. Reference sites are represented by black circles and solid regression line. 




Figure 54. Mean conductivity versus mean percent organic matter composition in leaf litter packs after 325 days. Reclaimed mine perimeter channel sites are represented by black triangles and dotted regression line. Reference sites are represented by black circles and solid regression line. 


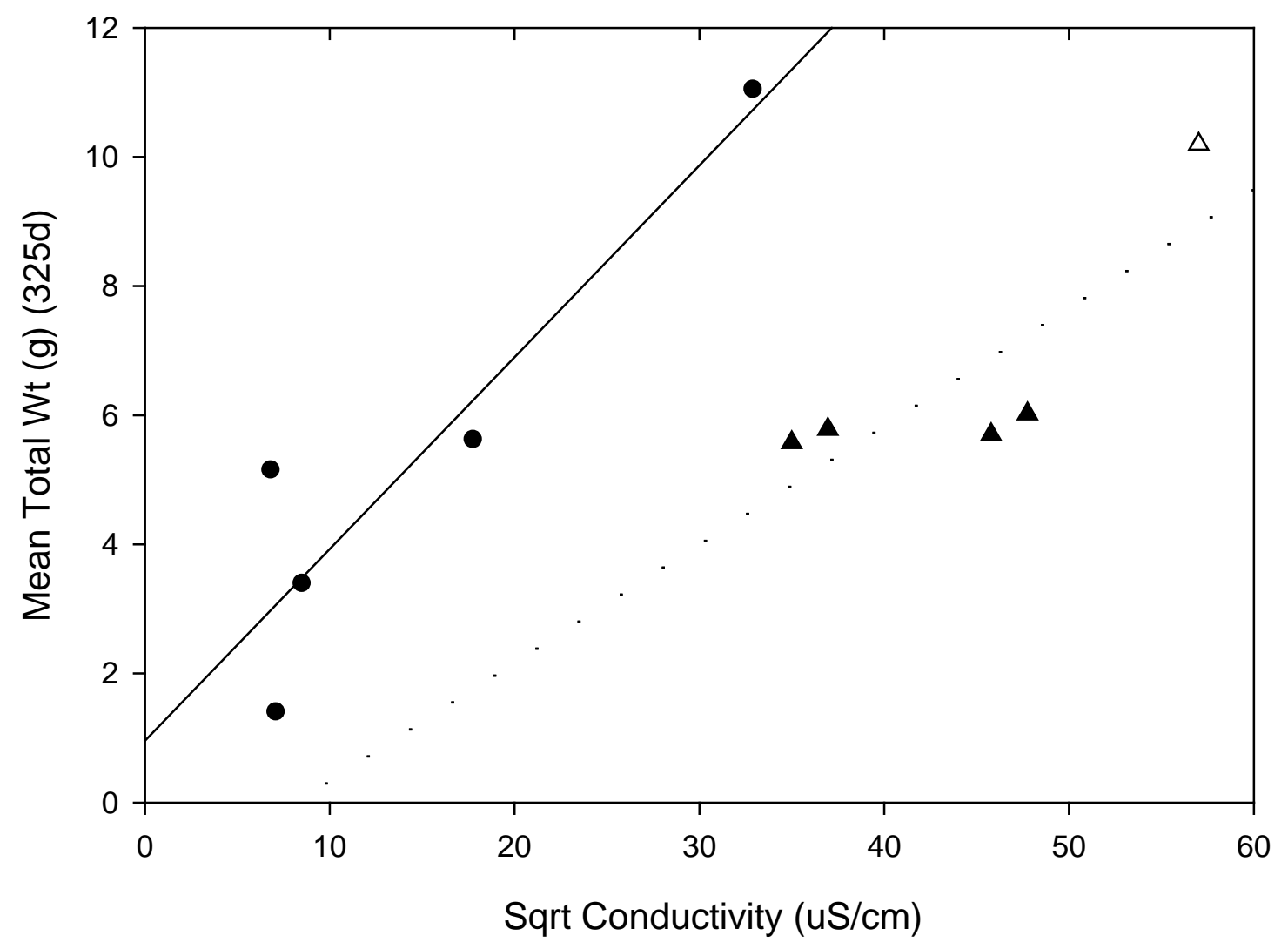

Figure 55. Mean conductivity versus mean total weight of leaf litter packs after $\sim 325$ days. Reclaimed mine perimeter channel sites are represented by black triangles and dotted regression line. Reference sites are represented by black circles and solid regression line. 


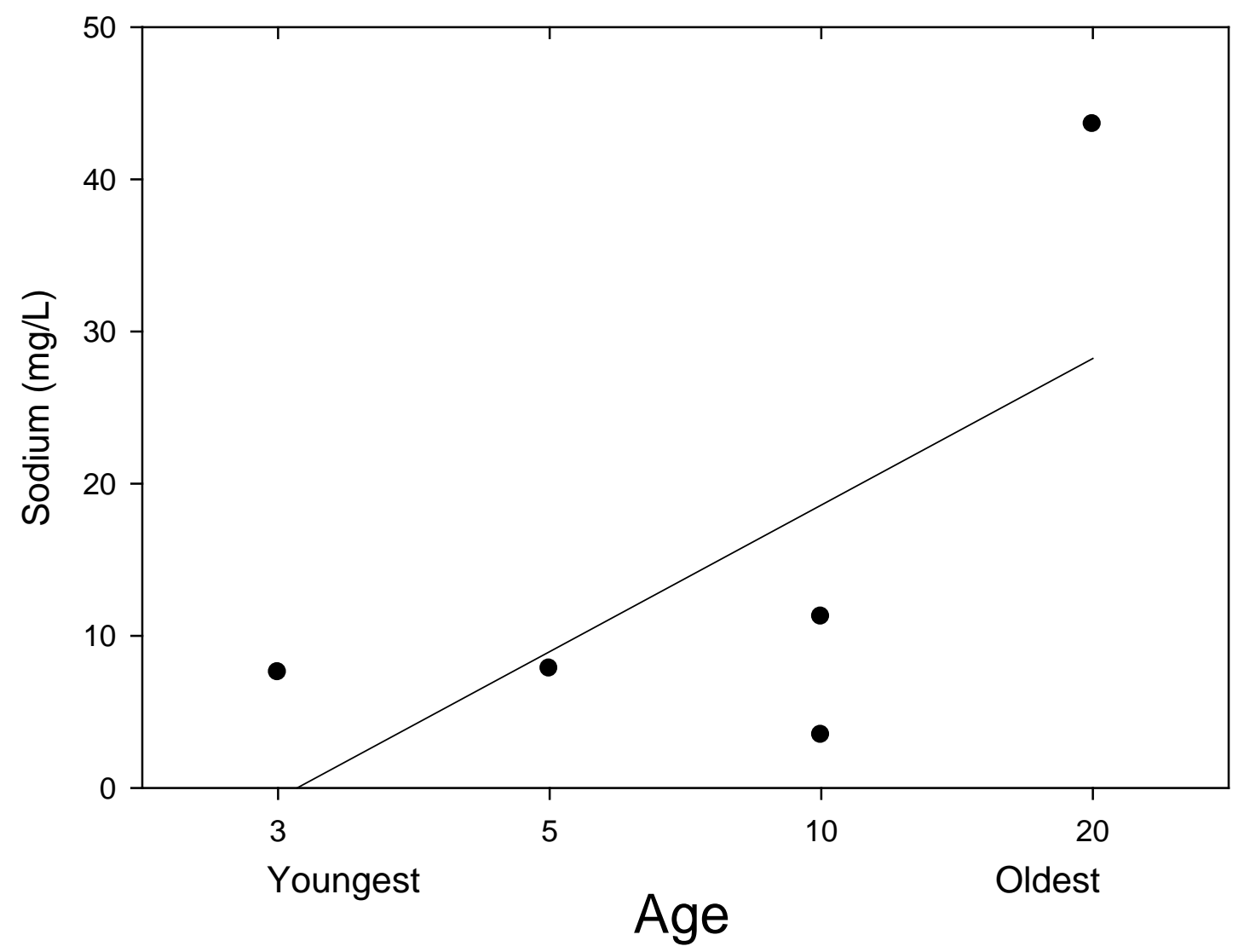

Figure 56. Mean sodium (mg/L) levels for reclaimed mine perimeter channel sites in order of age since reclamation. Confidence interval for reference sites (-16.7 - 71.1 $\mathrm{mg} / \mathrm{L}$ ) is not shown. 


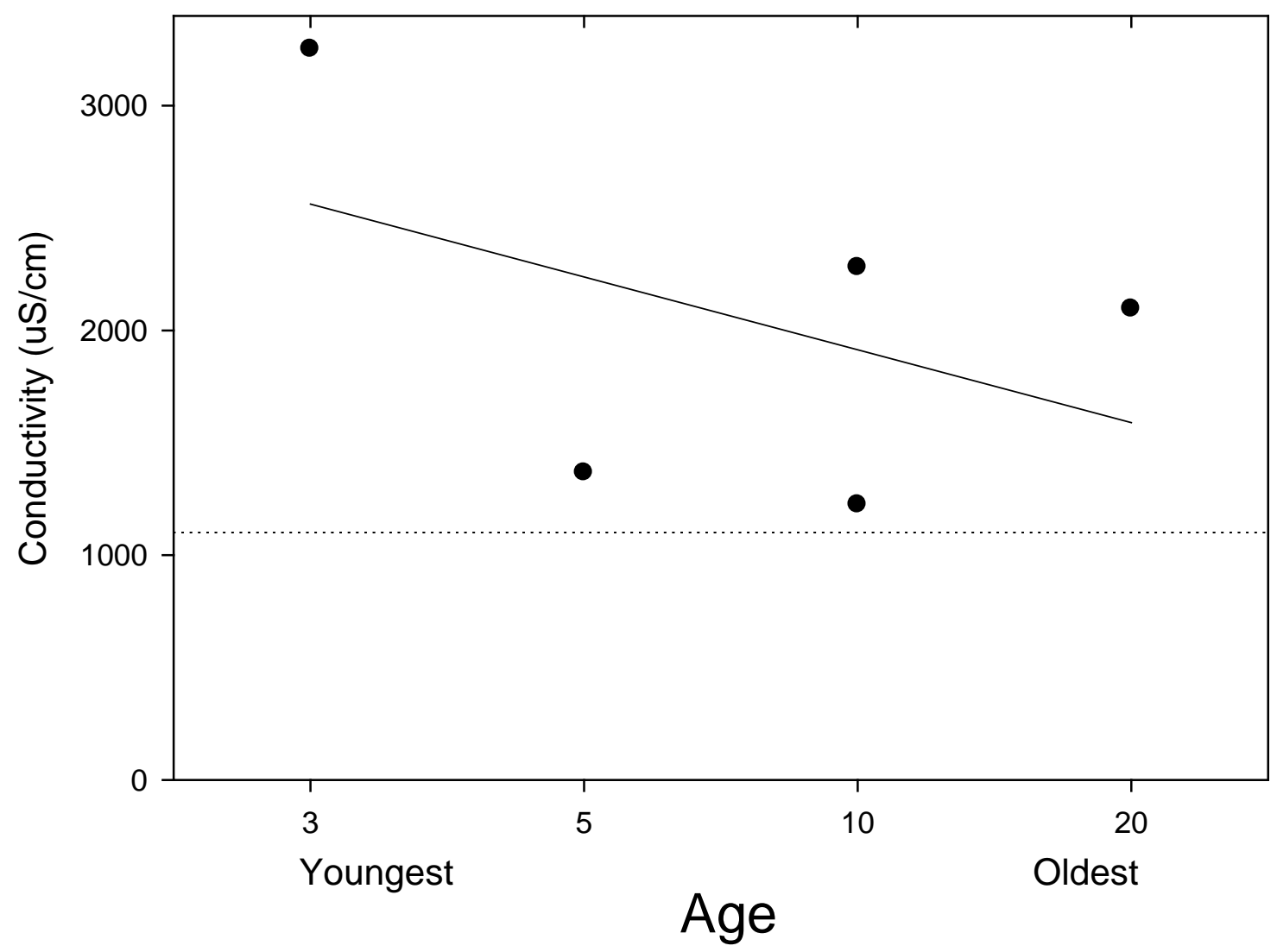

Figure 57. Mean conductivity $(\mu \mathrm{S} / \mathrm{cm})$ levels for reclaimed mine perimeter channel sites in order of age since reclamation. Confidence interval for reference sites $(-179-1101$ $\mu \mathrm{S} / \mathrm{cm}$ ) is shown (dotted line). 


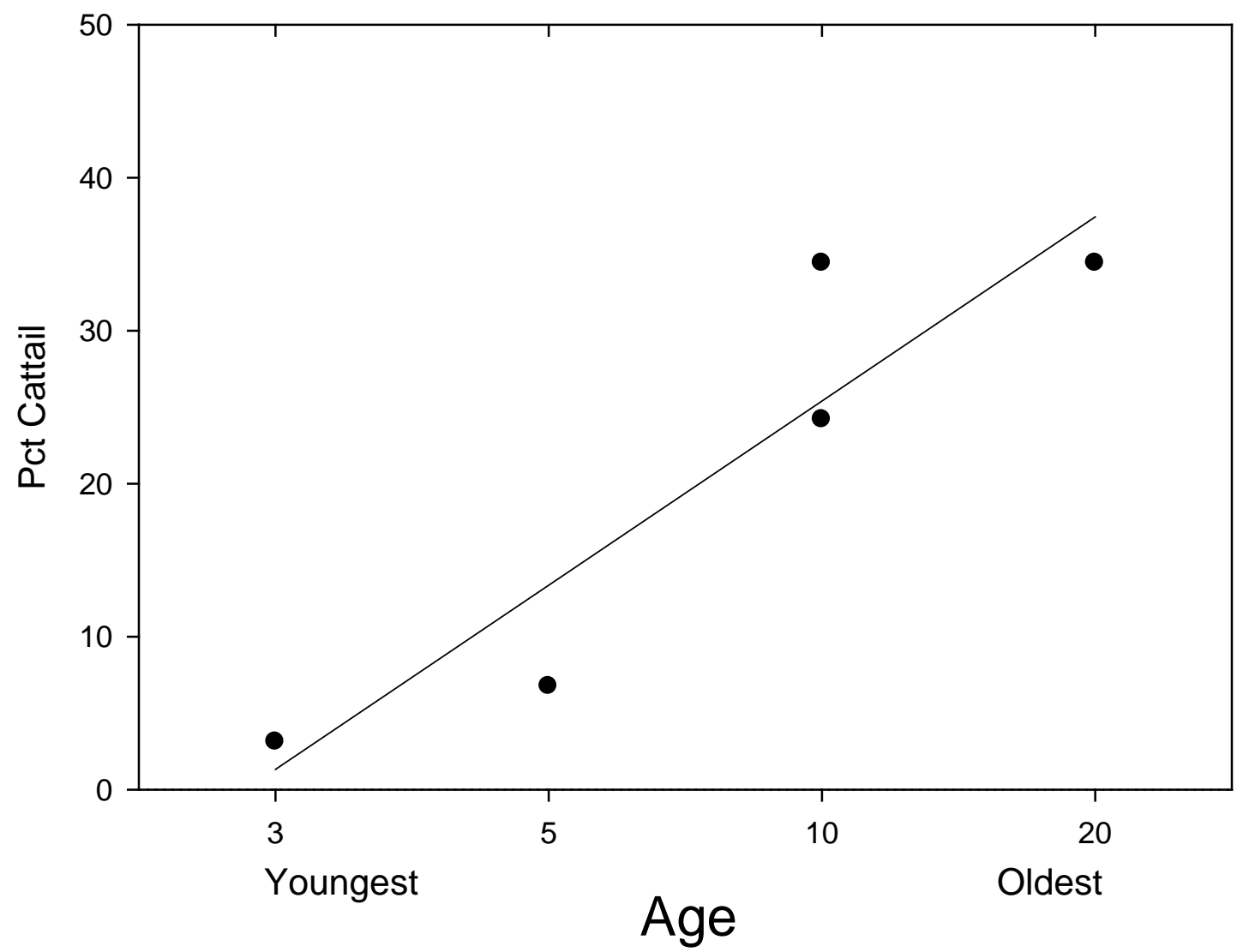

Figure 58. Percent cattail for reclaimed mine perimeter channel sites in order of age since reclamation. Confidence interval for reference sites was zero. 


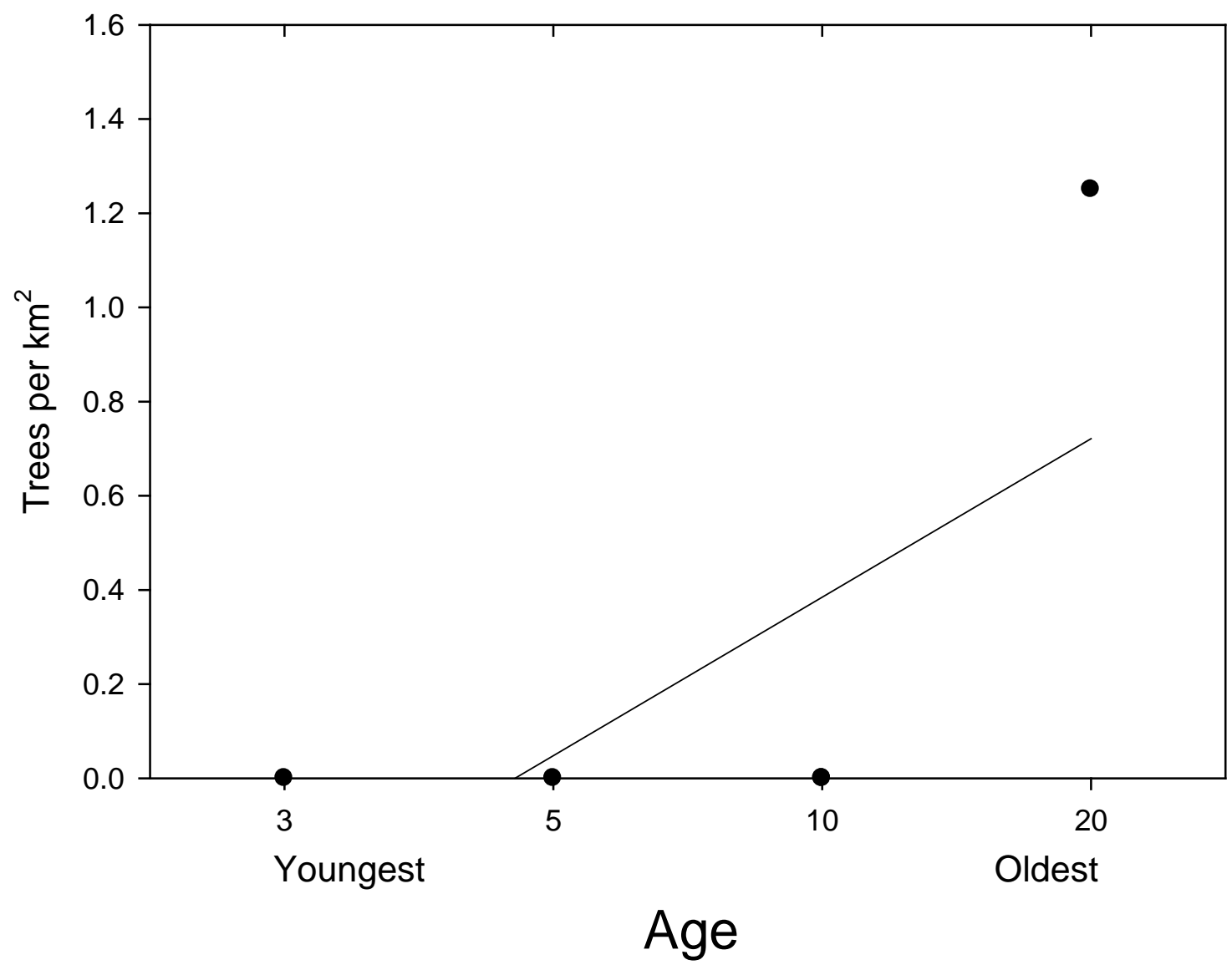

Figure 59. Trees per $\mathrm{km}^{2}$ for reclaimed mine perimeter channel sites in order of age since reclamation. Confidence interval for reference sites $(4.8-13.5)$ is not shown. 


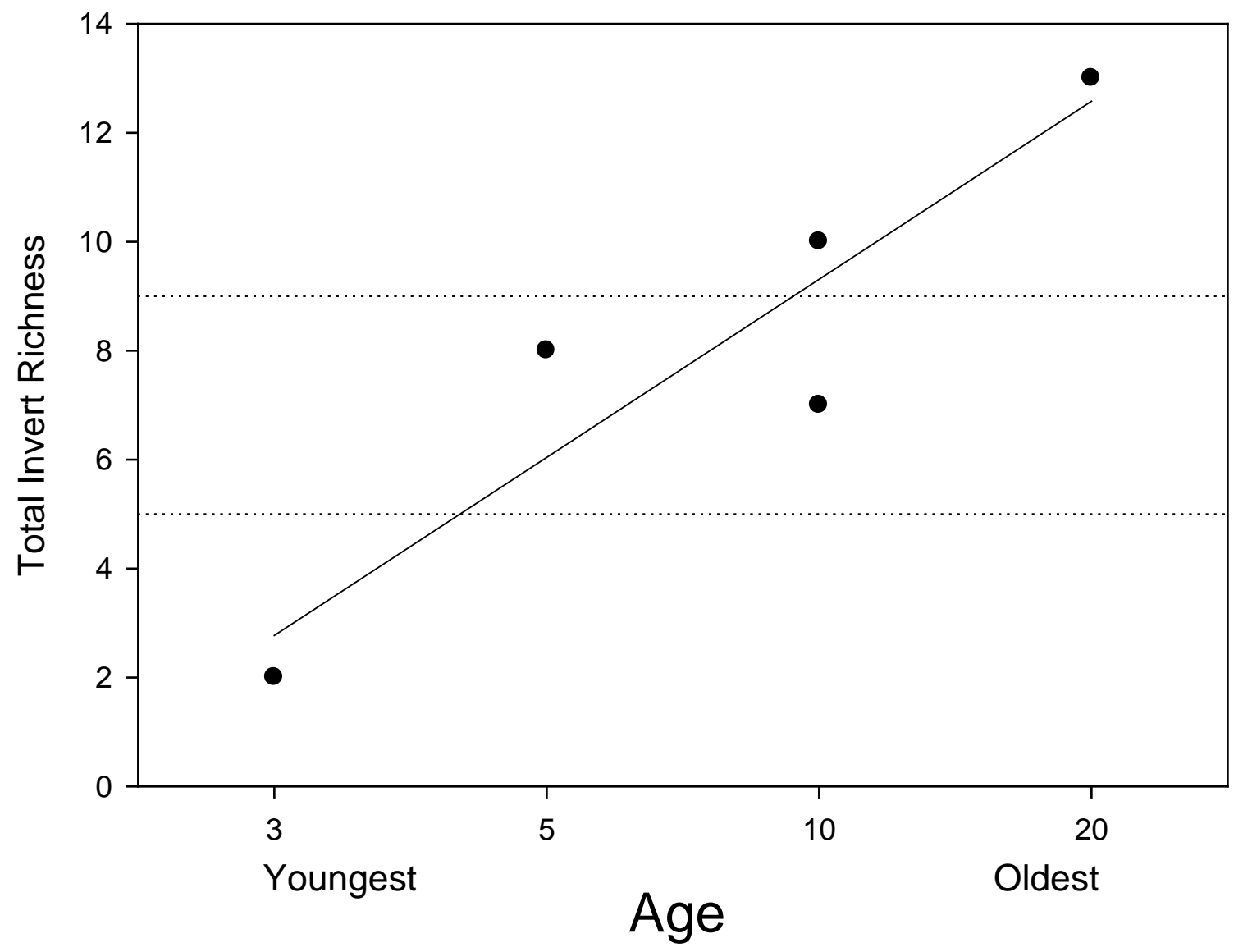

Figure 60. Total invertebrate richness for reclaimed mine perimeter channel sites in order of age since reclamation. Confidence interval for reference sites (5-9) is shown (dotted line). 


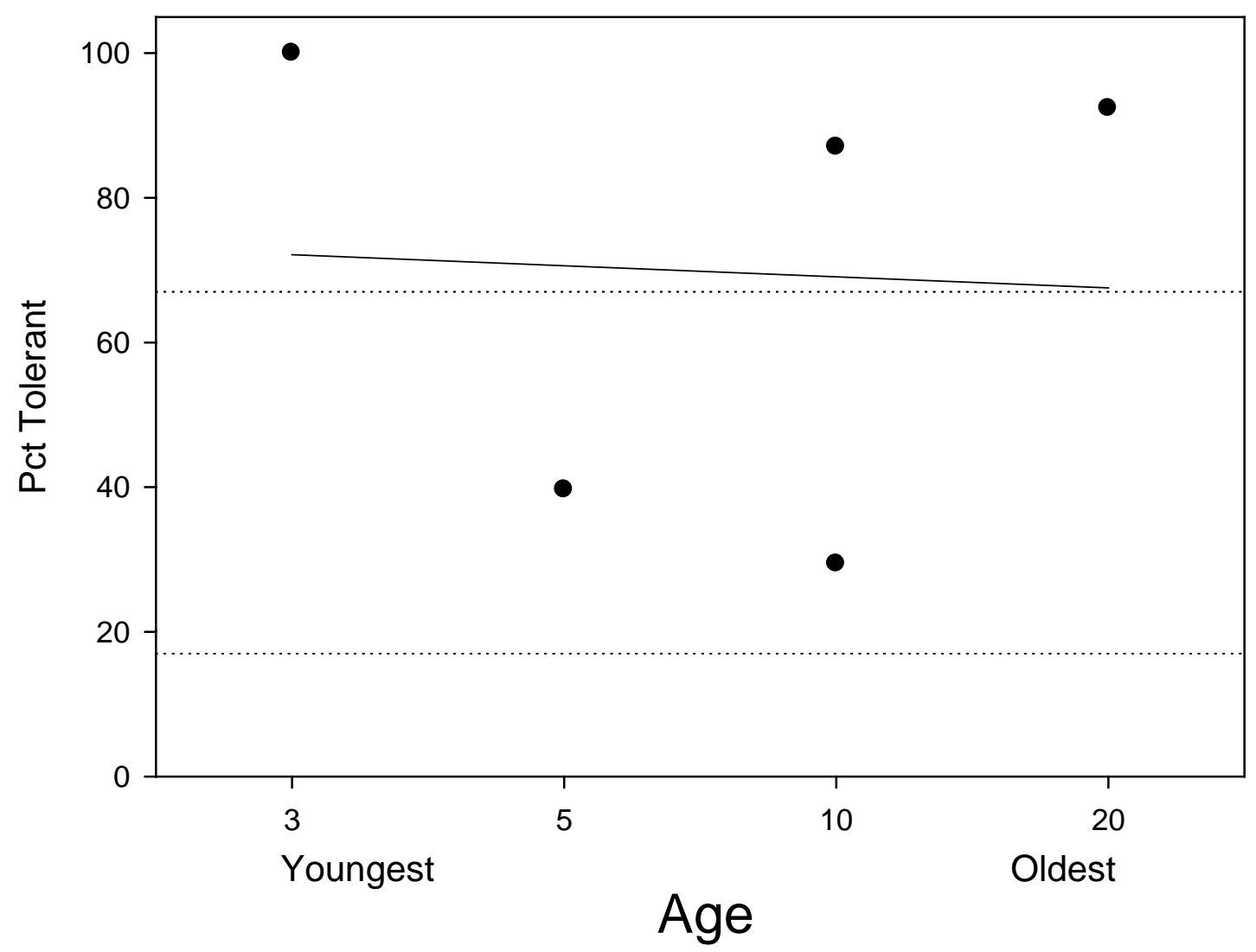

Figure 61. Percent tolerant invertebrates for reclaimed mine perimeter channel sites in order of age since reclamation. Confidence interval for reference sites $(17-67)$ is shown (dotted line). 


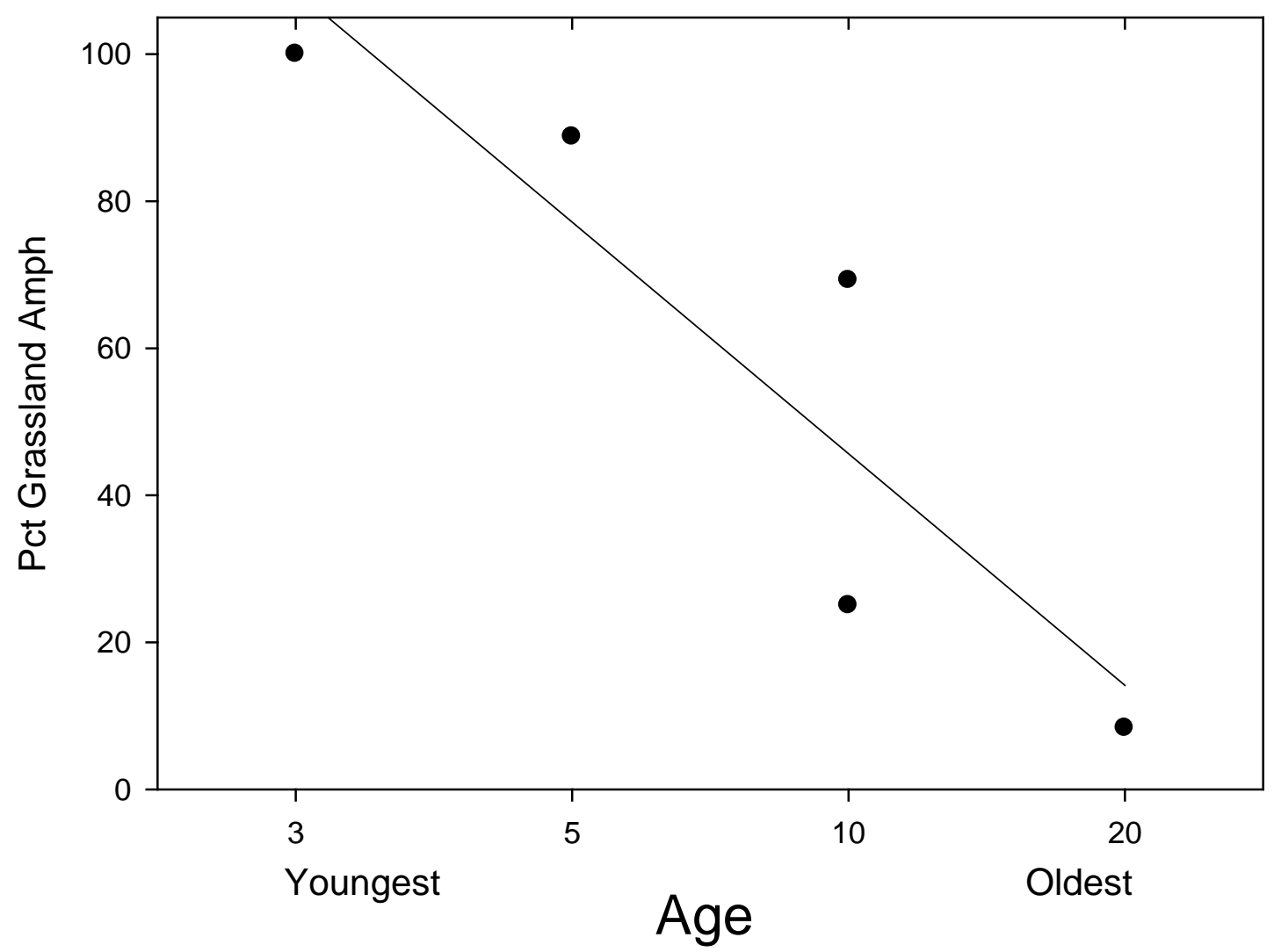

Figure 62. Percent grassland amphibians for reclaimed mine perimeter channel sites in order of age since reclamation. Confidence interval for reference sites (0) is not shown. 
Appendices

Appendix A. Seasonal water chemistry measures for reference sites and reclaimed mine perimeter channels. Reference sites did not contain enough water for sampling during autumn. MDL= method detection limit. Mean and standard deviation by site type are given in the last two rows. Perimeter channel sites are listed in increasing age since reclamation.

\begin{tabular}{|c|c|c|c|c|c|c|c|c|c|}
\hline & Season & $\begin{array}{c}\text { Acidity } \\
\text { mg/L }\end{array}$ & $\begin{array}{c}\text { Alk } \\
\mathrm{mg} / \mathrm{L}\end{array}$ & $\begin{array}{l}\text { Cond } \\
\mu S / c m\end{array}$ & $\begin{array}{c}\mathrm{Ca} \\
\mathrm{mg} / \mathrm{L}\end{array}$ & $\begin{array}{c}\mathrm{Mg} \\
\mathrm{mg} / \mathrm{L}\end{array}$ & $\begin{array}{c}\mathrm{SO}_{4} \\
\mathrm{mg} / \mathrm{L}\end{array}$ & $\begin{array}{c}\mathrm{Na} \\
\mathrm{mg} / \mathrm{L}\end{array}$ & $\begin{array}{c}\mathrm{Cl} \\
\mathrm{mg} / \mathrm{L}\end{array}$ \\
\hline \multirow{4}{*}{ P_WO } & Spring & 0 & 181 & - & 241 & 231 & 1245 & - & - \\
\hline & Summer & 0 & 194 & 3230 & 316 & 302 & 2131 & 7.43 & 6.9 \\
\hline & Autumn & 0 & 207 & 3620 & 403 & 442 & 2120 & 7.66 & 9.2 \\
\hline & Winter & 0 & 144 & 2905 & 266 & 276 & 1555 & 7.64 & 6.3 \\
\hline \multirow{4}{*}{ P_AR } & Spring & 0 & 139 & 1382 & 28 & 66 & 660 & 5.84 & 2.3 \\
\hline & Summer & 0 & 123 & 1343 & 176 & 77 & 776 & 7.21 & 0.6 \\
\hline & Autumn & 0 & 131 & 1428 & 219 & 95 & 715 & 8.15 & 2.3 \\
\hline & Winter & 0 & 104 & 1311 & 185 & 92 & 652 & 10.11 & 4.3 \\
\hline \multirow{4}{*}{ P_ST } & Spring & 0 & 168 & - & 222 & 206 & 1390 & 20.91 & 4.3 \\
\hline & Summer & 0 & 208 & 2560 & 246 & 254 & 1747 & 7.87 & 8.8 \\
\hline & Autumn & 0 & 203 & 3250 & 404 & 486 & 2290 & 12.32 & 9.8 \\
\hline & Winter & 0 & 125 & 1030 & 67 & 65 & 448 & 3.84 & 1.7 \\
\hline \multirow{4}{*}{ P_SU } & Spring & 0 & 114 & 769 & 40 & 39 & 282 & 1.83 & 1.4 \\
\hline & Summer & 0 & 128 & 741 & 61 & 50 & 297 & 2.29 & 0.3 \\
\hline & Autumn & 0 & 156 & 1452 & 161 & 140 & 695 & 6.27 & 3.3 \\
\hline & Winter & 0 & 109 & 1937 & 197 & 194 & 996 & - & 5.7 \\
\hline \multirow{4}{*}{ P_BH } & Spring & 0 & 127 & - & 149 & 152 & 1026 & 40.25 & 43.1 \\
\hline & Summer & 0 & 131 & 2120 & 155 & 179 & 1212 & 44.31 & 90.6 \\
\hline & Autumn & 0 & 172 & 2580 & 263 & 382 & 1475 & 61.43 & 111.2 \\
\hline & Winter & 0 & 78 & 1588 & 98 & 120 & 702 & 28.40 & 24.3 \\
\hline \multirow{4}{*}{ Perimeter } & Spring & $0 \pm 0$ & $146 \pm 28$ & $1076 \pm 628$ & $136 \pm 99$ & $139 \pm 84$ & $921 \pm 451$ & $17.21 \pm 16.94$ & $12.8 \pm 18.4$ \\
\hline & Summer & $0 \pm 0$ & $157 \pm 40$ & $1999 \pm 982$ & $191 \pm 96$ & $172 \pm 109$ & $1233 \pm 734$ & $13.82 \pm 17.19$ & $21.4 \pm 38.8$ \\
\hline & Autumn & $0 \pm 0$ & $174 \pm 32$ & $2466 \pm 1008$ & $290 \pm 110$ & $309 \pm 179$ & $1459 \pm 752$ & $19.17 \pm 23.73$ & $27.1 \pm 47.1$ \\
\hline & Winter & $0 \pm 0$ & $112 \pm 24$ & $1754 \pm 726$ & $163 \pm 80$ & $150 \pm 86$ & $871 \pm 430$ & $12.50 \pm 10.98$ & $8.5 \pm 9.0$ \\
\hline
\end{tabular}


Appendix A continued.

\begin{tabular}{|c|c|c|c|c|c|c|c|c|c|}
\hline & Season & $\begin{array}{c}\text { Acidity } \\
\text { mg/L }\end{array}$ & $\begin{array}{c}\text { Alk } \\
\mathrm{mg} / \mathrm{L}\end{array}$ & $\begin{array}{r}\text { Cond } \\
\mu S / \mathrm{cm}\end{array}$ & $\begin{array}{c}\mathrm{Ca} \\
\mathrm{mg} / \mathrm{L}\end{array}$ & $\begin{array}{c}\mathrm{Mg} \\
\mathrm{mg} / \mathrm{L}\end{array}$ & $\begin{array}{c}\mathrm{SO}_{4} \\
\mathrm{mg} / \mathrm{L}\end{array}$ & $\begin{array}{c}\mathrm{Na} \\
\mathrm{mg} / \mathrm{L}\end{array}$ & $\begin{array}{c}\mathrm{Cl} \\
\mathrm{mg} / \mathrm{L}\end{array}$ \\
\hline \multirow{4}{*}{ R_HC } & Spring & 21 & - & 54 & 123 & 1 & - & 0.42 & 1.9 \\
\hline & Summer & 12 & 6 & 2740 & 103 & 56 & 8 & 293.22 & - \\
\hline & Autumn & - & - & - & - & - & - & - & - \\
\hline & Winter & - & 4 & 462 & 16 & 12 & 10 & 44.00 & 102.4 \\
\hline \multirow{4}{*}{ R_LF } & Spring & 4 & 7 & - & 3 & 2 & 13 & - & 0.8 \\
\hline & Summer & - & 8 & 52 & 3 & 2 & 10 & 0.41 & 0.9 \\
\hline & Autumn & - & - & - & - & - & - & - & - \\
\hline & Winter & 4 & 7 & 50 & 2 & 2 & 11 & 0.86 & 1.3 \\
\hline \multirow{4}{*}{ R_ME } & Spring & 6 & 9 & 67 & 4 & 3 & 16 & 1.78 & 1.1 \\
\hline & Summer & 5 & 11 & 64 & 3 & 3 & 13 & 0.42 & 0.9 \\
\hline & Autumn & - & - & - & - & - & - & - & - \\
\hline & Winter & 7 & 5 & 89 & 3 & 3 & 13 & 4.76 & 1.1 \\
\hline \multirow{4}{*}{ R_MW } & Spring & 4 & 6 & 47 & 3 & 2 & 17 & 2.07 & 1.0 \\
\hline & Summer & 6 & 8 & 51 & 2 & 2 & 11 & 0.54 & 0.9 \\
\hline & Autumn & - & - & - & - & - & - & - & - \\
\hline & Winter & 8 & 2 & 44 & 2 & 2 & 13 & 2.41 & 1.1 \\
\hline \multirow{4}{*}{ R_WO } & Spring & 28 & - & - & 15 & 17 & 121 & . & 0.7 \\
\hline & Summer & 35 & 0 & 356 & 17 & 20 & 132 & 0.54 & 3.1 \\
\hline & Autumn & - & - & - & - & - & - & - & - \\
\hline & Winter & 32 & 0 & 278 & 12 & 15 & 86 & 2.41 & 1.2 \\
\hline \multirow{4}{*}{ Reference } & Spring & $13 \pm 11$ & $7 \pm 4$ & $56 \pm 31$ & $30 \pm 53$ & $5 \pm 7$ & $42 \pm 50$ & $1.42 \pm 1.00$ & $1.1 \pm 0.5$ \\
\hline & Summer & $14 \pm 14$ & $7 \pm 4$ & $652 \pm 1174$ & $26 \pm 44$ & $17 \pm 23$ & $35 \pm 54$ & $59.03 \pm 130.92$ & $1.4 \pm 1.2$ \\
\hline & Autumn & - & - & - & - & - & - & - & - \\
\hline & Winter & $13 \pm 12$ & $4 \pm 3$ & $185 \pm 182$ & $7 \pm 6$ & $7 \pm 6$ & $26 \pm 33$ & $10.89 \pm 18.56$ & $21.4 \pm 45.3$ \\
\hline
\end{tabular}


Appendix A continued.

\begin{tabular}{|c|c|c|c|c|c|c|c|c|}
\hline & Season & $\begin{array}{c}\mathrm{Al} \\
\mathrm{mg} / \mathrm{L}\end{array}$ & $\begin{array}{c}\mathrm{Fe} \\
\mathrm{mg} / \mathrm{L}\end{array}$ & $\begin{array}{c}\text { Se } \\
\mathrm{mg} / \mathrm{L}\end{array}$ & $\begin{array}{c}\mathrm{Zn} \\
\mathrm{mg} / \mathrm{L}\end{array}$ & $\begin{array}{c}\mathrm{Cd} \\
\mathrm{mg} / \mathrm{L}\end{array}$ & $\begin{array}{c}\mathrm{Cr} \\
\mathrm{mg} / \mathrm{L}\end{array}$ & $\begin{array}{c}\text { Co } \\
\mathrm{mg} / \mathrm{L}\end{array}$ \\
\hline \multirow{4}{*}{ P_WO } & Spring & 0.065 & 0.01 & MDL & MDL & MDL & MDL & 0.016 \\
\hline & Summer & 0.068 & 0.02 & MDL & 0.053 & MDL & MDL & 0.021 \\
\hline & Autumn & 0.130 & 1.06 & 0.148 & 0.141 & MDL & MDL & MDL \\
\hline & Winter & 0.104 & 0.11 & 0.052 & 0.097 & 0.012 & 0.013 & 0.013 \\
\hline \multirow{4}{*}{ P_AR } & Spring & 0.100 & 0.10 & MDL & MDL & MDL & MDL & MDL \\
\hline & Summer & 0.085 & 0.15 & MDL & MDL & MDL & MDL & MDL \\
\hline & Autumn & 0.100 & 0.54 & MDL & MDL & MDL & MDL & MDL \\
\hline & Winter & 0.036 & 0.05 & MDL & MDL & MDL & MDL & MDL \\
\hline \multirow{4}{*}{ P_ST } & Spring & 0.088 & 0.04 & MDL & MDL & MDL & MDL & MDL \\
\hline & Summer & 0.053 & 0.08 & MDL & MDL & MDL & MDL & MDL \\
\hline & Autumn & 0.100 & 1.11 & 0.173 & 0.071 & 0.057 & 0.066 & 0.054 \\
\hline & Winter & 0.061 & 0.07 & MDL & 0.018 & MDL & MDL & 0.013 \\
\hline \multirow{4}{*}{ P_SU } & Spring & 0.100 & 0.10 & MDL & MDL & MDL & MDL & MDL \\
\hline & Summer & 0.072 & 0.64 & MDL & MDL & MDL & MDL & 0.018 \\
\hline & Autumn & 0.100 & 0.69 & MDL & MDL & MDL & MDL & MDL \\
\hline & Winter & 0.037 & 0.03 & MDL & 0.035 & MDL & MDL & MDL \\
\hline \multirow{4}{*}{ P_BH } & Spring & 0.056 & 0.01 & MDL & MDL & MDL & MDL & 0.016 \\
\hline & Summer & 0.065 & 0.07 & MDL & 0.020 & MDL & MDL & MDL \\
\hline & Autumn & 0.100 & 1.02 & MDL & 0.115 & 0.023 & 0.025 & 0.021 \\
\hline & Winter & 0.069 & 0.08 & MDL & 0.023 & MDL & MDL & 0.013 \\
\hline \multirow{4}{*}{ Perimeter } & Spring & $0.082 \pm 0.020$ & $0.05 \pm 0.04$ & - & - & - & - & $0.016 \pm 0.009$ \\
\hline & Summer & $0.069 \pm 0.012$ & $0.19 \pm 0.25$ & - & $0.037 \pm 0.023$ & - & - & $0.020 \pm 0.011$ \\
\hline & Autumn & $0.106 \pm 0.013$ & $0.88 \pm 0.25$ & $0.161 \pm 0.088$ & $0.109 \pm 0.065$ & $0.040 \pm 0.025$ & $0.046 \pm 0.029$ & $0.038 \pm 0.024$ \\
\hline & Winter & $0.061 \pm 0.028$ & $0.07 \pm 0.03$ & $0.052 \pm 0.023$ & $0.043 \pm 0.037$ & $0.012 \pm 0.005$ & $0.013 \pm 0.006$ & $0.013 \pm 0.007$ \\
\hline
\end{tabular}


Appendix A continued.

\begin{tabular}{|c|c|c|c|c|c|c|c|c|}
\hline & Season & $\begin{array}{c}\mathrm{Al} \\
\mathrm{mg} / \mathrm{L}\end{array}$ & $\begin{array}{c}\mathrm{Fe} \\
\mathrm{mg} / \mathrm{L}\end{array}$ & $\begin{array}{c}\mathrm{Se} \\
\mathrm{mg} / \mathrm{L}\end{array}$ & $\begin{array}{c}\mathrm{Zn} \\
\mathrm{mg} / \mathrm{L}\end{array}$ & $\begin{array}{c}\mathrm{Cd} \\
\mathrm{mg} / \mathrm{L}\end{array}$ & $\begin{array}{c}\mathrm{Cr} \\
\mathrm{mg} / \mathrm{L}\end{array}$ & $\begin{array}{c}\mathrm{Co} \\
\mathrm{mg} / \mathrm{L}\end{array}$ \\
\hline \multirow{4}{*}{ R_HC } & Spring & 0.100 & 0.10 & MDL & MDL & MDL & 0.016 & MDL \\
\hline & Summer & 0.155 & 0.12 & MDL & MDL & MDL & MDL & MDL \\
\hline & Autumn & - & - & - & - & - & - & - \\
\hline & Winter & MDL & 0.01 & MDL & MDL & MDL & MDL & MDL \\
\hline \multirow{4}{*}{ R_LF } & Spring & MDL & 0.01 & MDL & MDL & MDL & MDL & 0.018 \\
\hline & Summer & 0.051 & 0.10 & MDL & MDL & MDL & MDL & MDL \\
\hline & Autumn & - & - & - & - & - & - & - \\
\hline & Winter & 0.085 & 0.06 & MDL & 0.018 & 0.012 & 0.020 & 0.013 \\
\hline \multirow{4}{*}{ R_ME } & Spring & 0.100 & 0.10 & MDL & 0.020 & MDL & MDL & MDL \\
\hline & Summer & 0.072 & 0.09 & MDL & MDL & MDL & MDL & MDL \\
\hline & Autumn & - & - & - & - & - & - & - \\
\hline & Winter & MDL & 0.01 & MDL & MDL & MDL & MDL & MDL \\
\hline \multirow{4}{*}{ R_MW } & Spring & 0.100 & 0.10 & MDL & 0.020 & MDL & MDL & MDL \\
\hline & Summer & 0.023 & 0.07 & 0.063 & 0.028 & MDL & 0.013 & MDL \\
\hline & Autumn & - & - & - & - & - & - & - \\
\hline & Winter & MDL & 0.01 & MDL & MDL & MDL & MDL & MDL \\
\hline \multirow{4}{*}{ R_WO } & Spring & 3.000 & 0.01 & 0.053 & 0.458 & MDL & MDL & - \\
\hline & Summer & 3.139 & 0.01 & 0.063 & 0.028 & MDL & MDL & MDL \\
\hline & Autumn & - & - & - & - & - & - & - \\
\hline & Winter & 1.308 & 0.10 & MDL & MDL & 0.012 & 0.015 & 0.016 \\
\hline \multirow{4}{*}{ Reference } & Spring & $0.825 \pm 1.309$ & $0.07 \pm 0.05$ & $0.053 \pm 0.024$ & $0.166 \pm 0.201$ & - & $0.016 \pm 0.007$ & $0.018 \pm 0.008$ \\
\hline & Summer & $0.069 \pm 1.371$ & $0.08 \pm 0.04$ & $0.063 \pm 0.035$ & $0.028 \pm 0.002$ & - & $0.013 \pm 0.006$ & - \\
\hline & Autumn & - & - & - & - & - & - & - \\
\hline & Winter & $0.696 \pm 0.569$ & $0.04 \pm 0.04$ & - & $0.018 \pm 0.008$ & $0.012 \pm 0.007$ & $0.017 \pm 0.010$ & $0.014 \pm 0.008$ \\
\hline
\end{tabular}


Appendix A continued.

\begin{tabular}{|c|c|c|c|c|c|c|c|c|c|}
\hline & Season & $\begin{array}{c}\mathrm{Cu} \\
\mathrm{mg} / \mathrm{L}\end{array}$ & $\begin{array}{c}\mathrm{Ba} \\
\mathrm{mg} / \mathrm{L}\end{array}$ & $\begin{array}{c}\mathrm{Mn} \\
\mathrm{mg} / \mathrm{L}\end{array}$ & $\begin{array}{c}\mathrm{Ni} \\
\mathrm{mg} / \mathrm{L}\end{array}$ & $\begin{array}{l}\mathrm{NO}_{2} \\
\mathrm{mg} / \mathrm{L}\end{array}$ & $\begin{array}{c}\mathrm{NO}_{3} \\
\mathrm{mg} / \mathrm{L}\end{array}$ & $\begin{array}{c}\mathrm{NH}_{3} \\
\mathrm{mg} / \mathrm{L}\end{array}$ & $\begin{array}{c}\mathrm{TP} \\
\mathrm{mg} / \mathrm{L}\end{array}$ \\
\hline \multirow{4}{*}{ P_WO } & Spring & MDL & 0.02 & 0.02 & 0.05 & MDL & MDL & MDL & MDL \\
\hline & Summer & MDL & 0.02 & 0.19 & 0.13 & 0.40 & 143.83 & 0.033 & 0.05 \\
\hline & Autumn & MDL & MDL & 0.19 & 0.06 & 0.10 & 79.27 & MDL & MDL \\
\hline & Winter & MDL & MDL & 0.42 & 0.14 & 0.07 & 13.53 & 0.009 & 0.68 \\
\hline \multirow{4}{*}{ P_AR } & Spring & MDL & 0.01 & 0.10 & MDL & MDL & 2.28 & MDL & MDL \\
\hline & Summer & MDL & 0.02 & 0.23 & MDL & 0.03 & 1.01 & 0.007 & 0.05 \\
\hline & Autumn & MDL & 0.02 & 0.16 & MDL & MDL & 0.24 & - & MDL \\
\hline & Winter & MDL & 0.02 & 0.05 & MDL & MDL & 2.25 & MDL & 0.07 \\
\hline \multirow{4}{*}{ P_ST } & Spring & MDL & 0.02 & 0.04 & 0.03 & MDL & 0.74 & MDL & MDL \\
\hline & Summer & MDL & 0.02 & 0.13 & MDL & 0.03 & - & 0.039 & 0.05 \\
\hline & Autumn & 0.061 & 0.07 & 0.10 & 0.06 & MDL & 0.70 & 0.087 & 0.07 \\
\hline & Winter & MDL & 0.02 & 0.06 & 0.02 & MDL & 0.17 & MDL & MDL \\
\hline \multirow{4}{*}{ P_SU } & Spring & MDL & 0.02 & 0.10 & MDL & MDL & 0.06 & 0.002 & 0.03 \\
\hline & Summer & MDL & 0.03 & 3.13 & 0.04 & 0.03 & 0.02 & 0.009 & 0.05 \\
\hline & Autumn & MDL & 0.04 & 0.10 & MDL & MDL & MDL & MDL & MDL \\
\hline & Winter & MDL & 0.02 & 0.02 & MDL & MDL & - & MDL & 0.06 \\
\hline \multirow{4}{*}{ P_BH } & Spring & MDL & MDL & 0.24 & MDL & MDL & MDL & MDL & MDL \\
\hline & Summer & MDL & 0.01 & 0.10 & MDL & 0.03 & 0.02 & 0.003 & 0.05 \\
\hline & Autumn & 0.027 & 0.02 & 0.10 & MDL & MDL & 0.03 & MDL & 0.05 \\
\hline & Winter & MDL & MDL & 0.07 & 0.02 & MDL & 0.93 & MDL & 0.08 \\
\hline \multirow{4}{*}{ Perimeter } & Spring & - & $0.02 \pm 0.01$ & $0.10 \pm 0.08$ & $0.04 \pm 0.02$ & - & $1.03 \pm 0.98$ & $0.002 \pm 0.001$ & $0.03 \pm 0.01$ \\
\hline & Summer & - & $0.02 \pm 0.01$ & $0.75 \pm 1.33$ & $0.09 \pm 0.06$ & $0.10 \pm 0.17$ & $36.22 \pm 64.21$ & $0.018 \pm 0.017$ & $0.05 \pm 0.00$ \\
\hline & Autumn & $0.044 \pm 0.027$ & $0.04 \pm 0.03$ & $0.13 \pm 0.04$ & $0.06 \pm 0.03$ & $0.10 \pm 0.04$ & $20.06 \pm 35.34$ & $0.087 \pm 0.039$ & $0.06 \pm 0.03$ \\
\hline & Winter & - & $0.02 \pm 0.01$ & $0.12 \pm 0.17$ & $0.19 \pm 0.06$ & $0.07 \pm 0.03$ & $4.22 \pm 5.75$ & $0.009 \pm 0.004$ & $0.22 \pm 0.28$ \\
\hline
\end{tabular}


Appendix A continued.

\begin{tabular}{|c|c|c|c|c|c|c|c|c|c|}
\hline & Season & $\begin{array}{c}\mathrm{Cu} \\
\mathrm{mg} / \mathrm{L}\end{array}$ & $\begin{array}{c}\mathrm{Ba} \\
\mathrm{mg} / \mathrm{L}\end{array}$ & $\begin{array}{r}\mathrm{Mn} \\
\mathrm{mg} / \mathrm{L}\end{array}$ & $\begin{array}{c}\mathrm{Ni} \\
\mathrm{mg} / \mathrm{L}\end{array}$ & $\begin{array}{c}\mathrm{NO}_{2} \\
\mathrm{mg} / \mathrm{L}\end{array}$ & $\begin{array}{c}\mathrm{NO}_{3} \\
\mathrm{mg} / \mathrm{L}\end{array}$ & $\begin{array}{c}\mathrm{NH}_{3} \\
\mathrm{mg} / \mathrm{L}\end{array}$ & $\begin{array}{c}\mathrm{TP} \\
\mathrm{mg} / \mathrm{L}\end{array}$ \\
\hline \multirow{4}{*}{ R_HC } & Spring & MDL & 0.01 & 0.10 & MDL & MDL & 0.11 & 0.006 & 0.03 \\
\hline & Summer & MDL & 0.89 & 0.36 & 0.03 & 46.23 & 1.85 & 0.056 & 0.05 \\
\hline & Autumn & - & - & - & - & - & - & - & - \\
\hline & Winter & MDL & 0.10 & 0.02 & MDL & MDL & 0.97 & MDL & MDL \\
\hline \multirow{4}{*}{ R_LF } & Spring & MDL & 0.03 & 0.02 & MDL & MDL & 0.24 & MDL & 0.06 \\
\hline & Summer & MDL & 0.03 & 0.03 & MDL & 0.06 & 1.61 & 0.012 & 0.05 \\
\hline & Autumn & - & - & - & - & - & - & - & - \\
\hline & Winter & MDL & 0.06 & 0.06 & 0.02 & MDL & 0.57 & 0.029 & 0.10 \\
\hline \multirow{4}{*}{ R_ME } & Spring & MDL & 0.03 & 0.10 & MDL & MDL & 1.06 & 0.009 & 0.08 \\
\hline & Summer & MDL & 0.04 & 0.04 & MDL & 0.03 & 1.79 & 0.019 & 0.05 \\
\hline & Autumn & - & - & - & - & - & - & - & - \\
\hline & Winter & MDL & 0.02 & 0.02 & MDL & MDL & 0.69 & MDL & 0.06 \\
\hline \multirow{4}{*}{ R_MW } & Spring & MDL & 0.03 & 0.10 & MDL & MDL & MDL & 0.010 & MDL \\
\hline & Summer & MDL & 0.03 & 0.02 & MDL & 0.03 & 0.29 & 0.026 & 0.06 \\
\hline & Autumn & - & - & - & - & - & - & - & - \\
\hline & Winter & MDL & 0.01 & 0.02 & MDL & MDL & 0.12 & MDL & 0.08 \\
\hline \multirow{4}{*}{ R_WO } & Spring & MDL & 0.07 & 1.87 & 0.19 & MDL & 0.23 & MDL & 0.05 \\
\hline & Summer & MDL & 0.04 & 1.90 & MDL & 0.03 & 1.52 & 0.026 & 0.05 \\
\hline & Autumn & - & - & - & - & - & - & - & - \\
\hline & Winter & MDL & 0.03 & 1.10 & MDL & MDL & 0.43 & 0.003 & MDL \\
\hline \multirow{4}{*}{ Reference } & Spring & - & $0.03 \pm 0.02$ & $0.44 \pm 0.80$ & $0.03 \pm 0.08$ & - & $0.41 \pm 0.42$ & $0.008 \pm 0.005$ & $0.05 \pm 0.03$ \\
\hline & Summer & - & $0.20 \pm 0.38$ & $0.47 \pm 0.81$ & $0.02 \pm 0.01$ & $9.28 \pm 20.66$ & $1.41 \pm 0.64$ & $0.028 \pm 0.017$ & $0.05 \pm 0.01$ \\
\hline & Autumn & - & - & - & - & - & - & - & - \\
\hline & Winter & - & $0.04 \pm 0.03$ & $0.24 \pm 0.48$ & $0.02 \pm 0.01$ & - & $0.56 \pm 0.32$ & $0.016 \pm 0.012$ & $0.08 \pm 0.04$ \\
\hline
\end{tabular}


Appendix B. Seasonal temperature data for reference sites and perimeter channels for periods when streams contained water. Mean and standard deviation by site type are given in the last two rows. Perimeter channel sites are listed in order of increasing age since reclamation.

\begin{tabular}{|c|c|c|c|c|c|}
\hline Site Code & Season & $\begin{array}{l}\text { Max Daily } \\
\text { Temp }\left({ }^{\circ} \mathrm{C}\right)\end{array}$ & $\begin{array}{l}\text { Min Daily } \\
\text { Temp }\left({ }^{\circ} \mathrm{C}\right)\end{array}$ & $\begin{array}{l}\text { Mean Daily } \\
\text { Temp }\left({ }^{\circ} \mathrm{C}\right)\end{array}$ & $\begin{array}{l}\text { CV for Mean } \\
\text { Daily Temp }\end{array}$ \\
\hline \multirow{4}{*}{ P_WO } & Spring & - & - & - & - \\
\hline & Summer & - & - & - & - \\
\hline & Autumn & - & - & - & - \\
\hline & Winter & - & - & - & - \\
\hline \multirow{4}{*}{ P_AR } & Spring & 20.5 & 5.3 & 13.9 & 23.0 \\
\hline & Summer & 22.1 & 15.4 & 18.3 & 5.3 \\
\hline & Autumn & 16.6 & 3.9 & 9.0 & 40.9 \\
\hline & Winter & 13.4 & 0.4 & 5.0 & 53.0 \\
\hline \multirow{4}{*}{ P_ST } & Spring & 26.1 & 6.3 & 16.7 & 23.2 \\
\hline & Summer & 28.2 & 13.8 & 20.2 & 7.8 \\
\hline & Autumn & 18.2 & 1.4 & 8.5 & 52.2 \\
\hline & Winter & 19.2 & 0.1 & 5.5 & 72.6 \\
\hline \multirow{4}{*}{ P_SU } & Spring & 40.6 & 5.3 & 15.6 & 26.7 \\
\hline & Summer & 29.1 & 15.8 & 22.6 & 6.4 \\
\hline & Autumn & 22.1 & 0.0 & 9.6 & 55.4 \\
\hline & Winter & 16.4 & 0.0 & 5.1 & 59.2 \\
\hline \multirow{4}{*}{ P_BH } & Spring & 34.6 & 2.0 & 16.1 & 27.6 \\
\hline & Summer & 30.3 & 13.4 & 21.0 & 8.2 \\
\hline & Autumn & 19.9 & 0.0 & 8.1 & 66.9 \\
\hline & Winter & 22.3 & 0.0 & 3.7 & 112.7 \\
\hline \multirow{4}{*}{ Perimeter } & Spring & $30.4 \pm 15.6$ & $4.7 \pm 2.7$ & $15.6 \pm 7.0$ & - \\
\hline & Summer & $27.4 \pm 12.7$ & $14.6 \pm 6.6$ & $20.5 \pm 9.3$ & - \\
\hline & Autumn & $19.2 \pm 8.8$ & $1.3 \pm 1.7$ & $8.8 \pm 4.0$ & - \\
\hline & Winter & $17.8 \pm 8.6$ & $0.1 \pm 0.2$ & $4.8 \pm 2.3$ & - \\
\hline
\end{tabular}


Appendix B continued.

\begin{tabular}{|c|c|c|c|c|c|}
\hline Site Code & Season & $\begin{array}{l}\text { Max Daily } \\
\text { Temp }\left({ }^{\circ} \mathrm{C}\right)\end{array}$ & $\begin{array}{l}\text { Min Daily } \\
\text { Temp }\left({ }^{\circ} \mathrm{C}\right)\end{array}$ & $\begin{array}{l}\text { Mean Daily } \\
\text { Temp }\left({ }^{\circ} \mathrm{C}\right)\end{array}$ & $\begin{array}{l}\text { CV for Mean } \\
\text { Daily Temp }\end{array}$ \\
\hline \multirow{4}{*}{ R_HC } & Spring & 33.2 & 10.0 & 17.4 & 15.6 \\
\hline & Summer & 38.9 & 11.7 & 20.1 & 6.5 \\
\hline & Autumn & 18.2 & 4.2 & 10.0 & 31.3 \\
\hline & Winter & 13.9 & 0.0 & 8.1 & 34.3 \\
\hline \multirow{4}{*}{ R_LF } & Spring & 31.4 & 2.7 & 12.9 & 33.0 \\
\hline & Summer & 29.3 & 10.5 & 19.6 & 9.0 \\
\hline & Autumn & 23.9 & 0.0 & 7.8 & 66.0 \\
\hline & Winter & 10.7 & 0.0 & 4.1 & 69.0 \\
\hline \multirow{4}{*}{ R_ME } & Spring & 22.5 & 6.2 & 11.8 & 23.9 \\
\hline & Summer & 24.3 & 11.0 & 18.3 & 8.3 \\
\hline & Autumn & 19.5 & 0.0 & 8.3 & 51.0 \\
\hline & Winter & 10.6 & 0.0 & 5.3 & 42.4 \\
\hline \multirow{4}{*}{ R_MW } & Spring & 34.1 & 1.7 & 13.2 & 32.1 \\
\hline & Summer & 16.1 & 0.0 & 5.2 & 63.9 \\
\hline & Autumn & 6.6 & 3.8 & 5.0 & 15.5 \\
\hline & Winter & 17.4 & 0.0 & 5.2 & 62.2 \\
\hline \multirow{4}{*}{ R_WO } & Spring & 28.2 & 13.4 & 15.9 & 6.4 \\
\hline & Summer & 32.2 & 12.3 & 19.0 & 10.4 \\
\hline & Autumn & 24.9 & 0.0 & 8.9 & 55.4 \\
\hline & Winter & 15.8 & 0.0 & 4.0 & 71.2 \\
\hline \multirow{4}{*}{ Reference } & Spring & $29.9 \pm 4.7$ & $6.8 \pm 4.9$ & $14.3 \pm 2.3$ & - \\
\hline & Summer & $28.2 \pm 8.6$ & $9.1 \pm 5.1$ & $16.4 \pm 6.3$ & - \\
\hline & Autumn & $18.6 \pm 7.3$ & $1.6 \pm 2.2$ & $8.0 \pm 1.9$ & - \\
\hline & Winter & $13.2 \pm 6.5$ & $0.0 \pm 10.0$ & $5.7 \pm 2.9$ & - \\
\hline
\end{tabular}


Appendix C. Adult amphibian abundance totals observed on reclaimed mine perimeter channels and reference streams for four sample periods. Totals by site type are given in the last two columns. Totals by site are given in the last two rows. Perimeter channel sites are listed in increasing age since reclamation.

\begin{tabular}{|c|c|c|c|c|c|c|c|c|c|c|c|c|}
\hline Species & P_WO & P_AR & P_ST & P_SU & P_BH & R_HC & R_LF & R_ME & R_MW & R_WO & Perimeter & Reference \\
\hline Desmognathus fuscus & 0 & 0 & 0 & 0 & 0 & 3 & 22 & 23 & 10 & 0 & 0 & 58 \\
\hline Desmognathus monticola & 0 & 0 & 0 & 0 & 0 & 5 & 20 & 46 & 4 & 0 & 0 & 75 \\
\hline Desmognathus unknown & 0 & 0 & 0 & 0 & 0 & 0 & 1 & 0 & 1 & 0 & 0 & 2 \\
\hline Eurycea bislineata & 0 & 0 & 0 & 0 & 0 & 0 & 1 & 0 & 0 & 1 & 0 & 2 \\
\hline Gyrinophilus porphyriticus & 0 & 0 & 0 & 0 & 0 & 0 & 1 & 0 & 0 & 0 & 0 & 1 \\
\hline Notophthalmus v. viridescens & 5 & 1 & 0 & 1 & 0 & 0 & 0 & 0 & 0 & 0 & 7 & 0 \\
\hline Pseudacris c. crucifer & 0 & 0 & 0 & 0 & 0 & 0 & 0 & 0 & 0 & 1 & 0 & 1 \\
\hline Rana catesbeiana & 0 & 0 & 1 & 0 & 0 & 0 & 0 & 0 & 0 & 0 & 1 & 0 \\
\hline Rana clamitans & 0 & 1 & 1 & 0 & 0 & 0 & 0 & 0 & 0 & 0 & 2 & 0 \\
\hline Rana palustris & 1 & 0 & 1 & 0 & 0 & 0 & 0 & 0 & 0 & 0 & 2 & 0 \\
\hline Rana sp. & 0 & 15 & 0 & 0 & 0 & 0 & 0 & 0 & 0 & 0 & 15 & 0 \\
\hline Total Individuals & 6 & 17 & 3 & 1 & 0 & 8 & 45 & 69 & 15 & 2 & 27 & 139 \\
\hline Total Species & 2 & 3 & 3 & 1 & 0 & 2 & 5 & 2 & 3 & 2 & 5 & 6 \\
\hline
\end{tabular}


Appendix D. Larval amphibian abundance survey totals observed on reclaimed mine perimeter channels and reference streams for four sample periods. Totals by site type are given in the last two columns. Totals by site are given in the last two rows. Perimeter channel sites are listed in increasing age since reclamation.

\begin{tabular}{|c|c|c|c|c|c|c|c|c|c|c|c|c|}
\hline Species & P_WO & P_AR & P_ST & P_SU & P_BH & R_HC & R_LF & R_ME & R_MW & R_WO & Perimeter & Reference \\
\hline Ambystoma sp. & 0 & 1 & 0 & 0 & 0 & 0 & 0 & 0 & 0 & 0 & 1 & 0 \\
\hline Bufo americana & 0 & 0 & 0 & 3 & 0 & 0 & 0 & 0 & 0 & 0 & 3 & 0 \\
\hline Desmognathus fuscus & 0 & 0 & 0 & 0 & 0 & 3 & 5 & 12 & 2 & 1 & 0 & 23 \\
\hline Eurycea cirrigera & 0 & 0 & 0 & 0 & 0 & 0 & 3 & 1 & 12 & 0 & 0 & 16 \\
\hline Hyla chrysoscelis & 0 & 1 & 0 & 1 & 11 & 0 & 0 & 0 & 0 & 0 & 13 & 0 \\
\hline Notophthalmus v. viridescens & 0 & 15 & 0 & 5 & 0 & 0 & 0 & 0 & 0 & 0 & 20 & 0 \\
\hline Pseudacris c. crucifer & 0 & 7 & 9 & 3 & 0 & 0 & 0 & 0 & 0 & 0 & 19 & 0 \\
\hline Rana clamitans & 0 & 39 & 0 & 0 & 1 & 0 & 0 & 0 & 0 & 0 & 40 & 0 \\
\hline Total Individuals & 0 & 63 & 9 & 12 & 12 & 3 & 8 & 13 & 14 & 1 & 96 & 39 \\
\hline Total Species & 0 & 5 & 1 & 4 & 2 & 1 & 2 & 2 & 2 & 1 & 6 & 2 \\
\hline
\end{tabular}


Appendix E. Combined larval and adult amphibian abundance survey totals observed on reclaimed mine perimeter channels and reference sites for four sample periods. Totals by site type are given in the last two columns. Totals by site are given in the last two rows. Perimeter channel sites are listed in order of increasing age since reclamation.

\begin{tabular}{|c|c|c|c|c|c|c|c|c|c|c|c|c|}
\hline Species & P_WO & P_AR & P_ST & P_SU & P_BH & R_HC & R_LF & R_ME & R_MW & R_WO & Perimeter & Reference \\
\hline Ambystoma sp. & 0 & 1 & 0 & 0 & 0 & 0 & 0 & 0 & 0 & 0 & 1 & 0 \\
\hline Bufo americana & 0 & 0 & 0 & 3 & 0 & 0 & 0 & 0 & 0 & 0 & 3 & 0 \\
\hline Desmognathus fuscus & 0 & 0 & 0 & 0 & 0 & 6 & 27 & 35 & 12 & 1 & 0 & 81 \\
\hline Desmognathus monticola & 0 & 0 & 0 & 0 & 0 & 5 & 20 & 46 & 4 & 0 & 0 & 75 \\
\hline Desmognathus unknown & 0 & 0 & 0 & 0 & 0 & 0 & 1 & 0 & 1 & 0 & 0 & 2 \\
\hline Eurycea bislineata & 0 & 0 & 0 & 0 & 0 & 0 & 1 & 0 & 0 & 1 & 0 & 2 \\
\hline Eurycea cirrigera & 0 & 0 & 0 & 0 & 0 & 0 & 3 & 1 & 12 & 0 & 0 & 16 \\
\hline Gyrinophilus porphyriticus & 0 & 0 & 0 & 0 & 0 & 0 & 1 & 0 & 0 & 0 & 0 & 1 \\
\hline Hyla chrysoscelis & 0 & 1 & 0 & 1 & 11 & 0 & 0 & 0 & 0 & 0 & 13 & 0 \\
\hline Notophthalmus v. viridescens & 5 & 16 & 0 & 6 & 0 & 0 & 0 & 0 & 0 & 0 & 27 & 0 \\
\hline Pseudacris c. crucifer & 0 & 7 & 9 & 3 & 0 & 0 & 0 & 0 & 0 & 1 & 19 & 1 \\
\hline Rana catesbeiana & 0 & 0 & 1 & 0 & 0 & 0 & 0 & 0 & 0 & 0 & 1 & 0 \\
\hline Rana clamitans & 0 & 40 & 1 & 0 & 1 & 0 & 0 & 0 & 0 & 0 & 42 & 0 \\
\hline Rana palustris & 1 & 0 & 1 & 0 & 0 & 0 & 0 & 0 & 0 & 0 & 2 & 0 \\
\hline Rana sp. & 0 & 15 & 0 & 0 & 0 & 0 & 0 & 0 & 0 & 0 & 15 & 0 \\
\hline Total Individuals & 6 & 80 & 12 & 13 & 12 & 11 & 53 & 82 & 29 & 3 & 123 & 178 \\
\hline Total Species & 2 & 6 & 4 & 4 & 2 & 2 & 6 & 3 & 4 & 3 & 9 & 7 \\
\hline
\end{tabular}


Appendix F. Macroinvertebrate abundance data given by Order (when known) for reclaimed mine perimeter channels and reference sites. Mean and standard deviation by site type are given in the last two columns. Perimeter channel sites are listed in order of increasing age since reclamation.

\begin{tabular}{|c|c|c|c|c|c|c|c|c|c|c|c|c|}
\hline Order & P_WO & P_AR & P_ST & P_SU & P_BH & R_HC & R_LF & R_ME & R_MW & R_WO & Perimeter & Reference \\
\hline Cladocera & 0 & 0 & 210 & 0 & 0 & 0 & 0 & 1 & 16 & 0 & $42 \pm 94$ & $3 \pm 7$ \\
\hline Clams & 0 & 0 & 8 & 0 & 16 & 0 & 0 & 0 & 0 & 0 & $5 \pm 7$ & $0 \pm 0$ \\
\hline Coleoptera & 0 & 8 & 15 & 0 & 3 & 0 & 0 & 0 & 0 & 0 & $5 \pm 7$ & $0 \pm 0$ \\
\hline Collembola & 0 & 0 & 0 & 0 & 24 & 0 & 0 & 8 & 56 & 0 & $5 \pm 11$ & $13 \pm 24$ \\
\hline Cyclopoida & 0 & 0 & 88 & 96 & 0 & 8 & 0 & 0 & 0 & 0 & $37 \pm 50$ & $2 \pm 4$ \\
\hline Diptera & 1329 & 33 & 56 & 1196 & 705 & 20 & 16 & 68 & 184 & 41 & $664 \pm 611$ & $66 \pm 69$ \\
\hline Ephemeroptera & 0 & 16 & 16 & 2 & 0 & 0 & 88 & 15 & 128 & 0 & $7 \pm 8$ & $46 \pm 58$ \\
\hline Hemiptera & 0 & 0 & 2 & 0 & 0 & 0 & 0 & 0 & 16 & 0 & $0 \pm 1$ & $3 \pm 7$ \\
\hline Odonata & 0 & 10 & 0 & 6 & 3 & 0 & 0 & 1 & 0 & 0 & $4 \pm 4$ & $0 \pm 0$ \\
\hline Oligochaeta & 0 & 1 & 0 & 8 & 56 & 8 & 0 & 0 & 8 & 8 & $13 \pm 24$ & $5 \pm 4$ \\
\hline Plecoptera & 0 & 0 & 0 & 1 & 0 & 3 & 41 & 208 & 135 & 11 & $0 \pm 0$ & $80 \pm 89$ \\
\hline Snails & 0 & 18 & 8 & 75 & 16 & 8 & 0 & 0 & 0 & 0 & $23 \pm 30$ & $2 \pm 4$ \\
\hline Trichoptera & 0 & 0 & 0 & 0 & 0 & 0 & 0 & 1 & 1 & 0 & $0 \pm 0$ & $0 \pm 1$ \\
\hline
\end{tabular}


Appendix G. Macroinvertebrate abundance data given as a percent by Order (when known) for reclaimed mine perimeter channels and reference streams. Mean and standard deviation by site type are given in the last two columns. Perimeter channel sites are listed in order of increasing age since reclamation.

\begin{tabular}{lcccccccccccc}
\hline \multicolumn{1}{c}{ Order } & P_WO & P_AR & P_ST & P_SU & P_BH & R_HC & R_LF & R_ME & R_MW & R_WO & Perimeter & Reference \\
\hline Cladocera & 0 & 0 & 52 & 0 & 0 & 0 & 0 & 0 & 3 & 0 & $10 \pm 23$ & $1 \pm 1$ \\
Clams & 0 & 0 & 2 & 0 & 2 & 0 & 0 & 0 & 0 & 0 & $1 \pm 1$ & $0 \pm 0$ \\
Coleoptera & 0 & 9 & 4 & 0 & 0 & 0 & 0 & 0 & 0 & 0 & $3 \pm 4$ & $0 \pm 0$ \\
Collembola & 0 & 0 & 0 & 0 & 3 & 0 & 0 & 3 & 10 & 0 & $1 \pm 1$ & $3 \pm 4$ \\
Cyclopoida & 0 & 0 & 22 & 7 & 0 & 17 & 0 & 0 & 0 & 0 & $6 \pm 9$ & $3 \pm 8$ \\
Diptera & 10 & 38 & 14 & 86 & 86 & 43 & 11 & 23 & 34 & 68 & $65 \pm 37$ & $36 \pm 22$ \\
Ephemeroptera & 0 & 19 & 4 & 0 & 0 & 0 & 61 & 5 & 24 & 0 & $5 \pm 8$ & $18 \pm 26$ \\
Hemiptera & 0 & 0 & 0 & 0 & 0 & 0 & 0 & 0 & 3 & 0 & $0 \pm 0$ & $1 \pm 1$ \\
Odonata & 0 & 12 & 0 & 0 & 0 & 0 & 0 & 0 & 0 & 0 & $2 \pm 5$ \\
Oligochaeta & 0 & 1 & 0 & 1 & 7 & 17 & 0 & 0 & 1 & 13 & $2 \pm 3$ \\
Plecoptera & 0 & 0 & 0 & 0 & 0 & 6 & 28 & 69 & 25 & 18 & 0 \\
Snails & 0 & 21 & 2 & 5 & 2 & 17 & 0 & 0 & 0 & 0 & $6 \pm 0$ \\
Trichoptera & 0 & 0 & 0 & 0 & 0 & 0 & 0 & 0 & 0 & 0 & 0 \\
\hline
\end{tabular}


Appendix H. Macroinvertebrate abundance data given by Genus (when known) for reclaimed mine perimeter channels and reference streams. Mean and standard deviation by site type are given in the last two columns. Perimeter channel sites are listed in order of increasing age since reclamation.

\begin{tabular}{|c|c|c|c|c|c|c|c|c|c|c|c|c|c|}
\hline Class/Order & Genera & P_WO & P_AR & P_ST & P_SU & P_BH & R_HC & R_LF & R_ME & R_MW & R_WO & Perimeter & Reference \\
\hline Oligochaeta & - & 0 & 1 & 0 & 8 & 56 & 8 & 0 & 0 & 8 & 8 & $13 \pm 24$ & $5 \pm 4$ \\
\hline Bivalvia (clam) & - & 0 & 0 & 8 & 0 & 16 & 0 & 0 & 0 & 0 & 0 & $5 \pm 7$ & $0 \pm 0$ \\
\hline Gastropoda (snail) & - & 0 & 18 & 8 & 75 & 16 & 8 & 0 & 0 & 0 & 0 & $23 \pm 30$ & $2 \pm 4$ \\
\hline Ephemeroptera & Baetis & 0 & 3 & 0 & 0 & 0 & 0 & 11 & 0 & 0 & 0 & $1 \pm 1$ & $2 \pm 5$ \\
\hline Ephemeroptera & Centroptilum & 0 & 13 & 0 & 0 & 0 & 0 & 0 & 0 & 0 & 0 & $3 \pm 6$ & $0 \pm 0$ \\
\hline Ephemeroptera & Acerpenna & 0 & 1 & 0 & 0 & 0 & 0 & 0 & 0 & 0 & 0 & $0 \pm 0$ & $0 \pm 0$ \\
\hline Ephemeroptera & Ephemerellidae(UNK) & 0 & 2 & 16 & 0 & 0 & 0 & 0 & 7 & 0 & 0 & $4 \pm 7$ & $1 \pm 3$ \\
\hline Ephemeroptera & Ephemerella & 0 & 0 & 0 & 0 & 0 & 0 & 2 & 0 & 35 & 0 & $0 \pm 0$ & $7 \pm 15$ \\
\hline Ephemeroptera & Ephemera & 0 & 0 & 0 & 0 & 0 & 0 & 0 & 0 & 5 & 0 & $0 \pm 0$ & $1 \pm 2$ \\
\hline Ephemeroptera & Ameletus & 0 & 0 & 0 & 2 & 0 & 0 & 67 & 0 & 102 & 0 & $0 \pm 1$ & $34 \pm 48$ \\
\hline Ephemeroptera & Mayfly(UNK) & 0 & 0 & 0 & 0 & 0 & 0 & 8 & 8 & 0 & 0 & $0 \pm 0$ & $3 \pm 4$ \\
\hline Trichoptera & Hydropsyche & 0 & 0 & 0 & 0 & 0 & 0 & 0 & 0 & 1 & 0 & $0 \pm 0$ & $0 \pm 0$ \\
\hline Trichoptera & Caddisfly(UNK) & 0 & 0 & 0 & 0 & 0 & 0 & 0 & 1 & 0 & 0 & $0 \pm 0$ & $0 \pm 0$ \\
\hline Plecoptera & Capnia & 0 & 0 & 0 & 0 & 0 & 0 & 1 & 0 & 0 & 0 & $0 \pm 0$ & $0 \pm 0$ \\
\hline Plecoptera & Leuctridae(UNK) & 0 & 0 & 0 & 0 & 0 & 3 & 0 & 49 & 74 & 11 & $0 \pm 0$ & $27 \pm 33$ \\
\hline Plecoptera & Leuctra & 0 & 0 & 0 & 0 & 0 & 0 & 12 & 0 & 0 & 0 & $0 \pm 0$ & $2 \pm 5$ \\
\hline Plecoptera & Capniidae/Leuctridae(UNK) & 0 & 0 & 0 & 0 & 0 & 0 & 0 & 0 & 16 & 0 & $0 \pm 0$ & $3 \pm 7$ \\
\hline Plecoptera & Perlodidae(UNK) & 0 & 0 & 0 & 0 & 0 & 0 & 0 & 0 & 16 & 0 & $0 \pm 0$ & $3 \pm 7$ \\
\hline Plecoptera & Isoperla & 0 & 0 & 0 & 0 & 0 & 0 & 12 & 0 & 0 & 0 & $0 \pm 0$ & $2 \pm 5$ \\
\hline Plecoptera & Yugus & 0 & 0 & 0 & 1 & 0 & 0 & 0 & 0 & 0 & 0 & $0 \pm 0$ & $0 \pm 0$ \\
\hline Plecoptera & Peltoperla & 0 & 0 & 0 & 0 & 0 & 0 & 16 & 150 & 0 & 0 & $0 \pm 0$ & $33 \pm 66$ \\
\hline Plecoptera & Nemouridae(UNK) & 0 & 0 & 0 & 0 & 0 & 0 & 0 & 9 & 3 & 0 & $0 \pm 0$ & $2 \pm 4$ \\
\hline
\end{tabular}


Appendix H continued.

\begin{tabular}{|c|c|c|c|c|c|c|c|c|c|c|c|c|c|}
\hline Class/Order & Genera & P_WO & P_AR & P_ST & P_SU & P_BH & R_HC & R_LF & R_ME & R_MW & R_WO & Perimeter & Reference \\
\hline Odonata & Gomphidae(UNK) & 0 & 8 & 0 & 0 & 0 & 0 & 0 & 0 & 0 & 0 & $2 \pm 4$ & $0 \pm 0$ \\
\hline Odonata & Libellulidae & 0 & 2 & 0 & 3 & 0 & 0 & 0 & 1 & 0 & 0 & $1 \pm 1$ & $0 \pm 0$ \\
\hline Odonata & Coenagrionidae & 0 & 0 & 0 & 3 & 3 & 0 & 0 & 0 & 0 & 0 & $1 \pm 2$ & $0 \pm 0$ \\
\hline Coleoptera & Dytiscidae(UNK) & 0 & 0 & 15 & 0 & 1 & 0 & 0 & 0 & 0 & 0 & $3 \pm 7$ & $0 \pm 0$ \\
\hline Coleoptera & Agabus & 0 & 0 & 0 & 0 & 2 & 0 & 0 & 0 & 0 & 0 & $0 \pm 1$ & $0 \pm 0$ \\
\hline Coleoptera & Peltodytes & 0 & 8 & 0 & 0 & 0 & 0 & 0 & 0 & 0 & 0 & $2 \pm 4$ & $0 \pm 0$ \\
\hline Diptera & Chironomidae & 1246 & 0 & 55 & 1112 & 0 & 0 & 0 & 0 & 0 & 24 & $483 \pm 638$ & $5 \pm 11$ \\
\hline Diptera & Tipulidae(UNK) & 0 & 0 & 0 & 0 & 1 & 1 & 0 & 0 & 0 & 0 & $0 \pm 0$ & $0 \pm 0$ \\
\hline Diptera & Tabanus & 0 & 0 & 0 & 0 & 0 & 0 & 8 & 0 & 0 & 0 & $0 \pm 0$ & $2 \pm 4$ \\
\hline Diptera & Chrysops & 0 & 0 & 0 & 0 & 1 & 0 & 0 & 0 & 0 & 0 & $0 \pm 0$ & $0 \pm 0$ \\
\hline Diptera & Simulium & 0 & 0 & 0 & 2 & 49 & 0 & 0 & 0 & 0 & 0 & $10 \pm 22$ & $0 \pm 0$ \\
\hline Diptera & Ceratopogonidae(UNK) & 83 & 8 & 1 & 0 & 0 & 0 & 0 & 0 & 0 & 0 & $18 \pm 36$ & $0 \pm 0$ \\
\hline Diptera & Bezzia & 0 & 0 & 0 & 0 & 1 & 0 & 0 & 0 & 0 & 0 & $0 \pm 0$ & $0 \pm 0$ \\
\hline Diptera & Stratiomyidae & 0 & 0 & 0 & 4 & 0 & 0 & 0 & 0 & 0 & 0 & $1 \pm 2$ & $0 \pm 0$ \\
\hline Diptera & Tanyderidae & 0 & 0 & 0 & 0 & 2 & 0 & 0 & 0 & 0 & 0 & $0 \pm 1$ & $0 \pm 0$ \\
\hline Diptera & Diptera(UNK) & 0 & 16 & 0 & 8 & 2 & 1 & 8 & 8 & 0 & 0 & $5 \pm 7$ & $3 \pm 4$ \\
\hline Diptera & Non-Tanypodinae & 0 & 9 & 0 & 35 & 593 & 18 & 0 & 51 & 176 & 17 & $127 \pm 261$ & $52 \pm 72$ \\
\hline Diptera & Tanypodinae & 0 & 0 & 0 & 35 & 56 & 0 & 0 & 0 & 0 & 0 & $18 \pm 26$ & $0 \pm 0$ \\
\hline Collembola & Sminthuridae(UNK) & 0 & 0 & 0 & 0 & 0 & 0 & 0 & 8 & 0 & 0 & $0 \pm 0$ & $2 \pm 4$ \\
\hline Collembola & Sminthurides & 0 & 0 & 0 & 0 & 0 & 0 & 0 & 0 & 56 & 0 & $0 \pm 0$ & $11 \pm 25$ \\
\hline Collembola & Agrenia bidenticulata & 0 & 0 & 0 & 0 & 24 & 0 & 0 & 0 & 0 & 0 & $5 \pm 11$ & $0 \pm 0$ \\
\hline Cyclopoida & Cladocera & 0 & 0 & 210 & 0 & 0 & 0 & 0 & 0 & 16 & 0 & $42 \pm 94$ & $3 \pm 7$ \\
\hline Hemiptera & Hemiptera(UNK) & 0 & 0 & 2 & 0 & 0 & 0 & 0 & 0 & 16 & 0 & $0 \pm 1$ & $3 \pm 7$ \\
\hline Hemiptera & Mesouelia & 0 & 0 & 0 & 0 & 0 & 0 & 0 & 0 & 0 & 0 & $0 \pm 0$ & $0 \pm 0$ \\
\hline Decapoda & Crayfish(UNK) & 0 & 0 & 0 & 0 & 0 & 0 & 0 & 1 & 0 & 0 & $0 \pm 0$ & $0 \pm 0$ \\
\hline Coleoptera & Hydrocanthus & 0 & 0 & 0 & 0 & 0 & 0 & 0 & 0 & 0 & 0 & $3 \pm 0$ & $0 \pm 0$ \\
\hline Calanoida & Copepod(UNK) & 0 & 0 & 88 & 96 & 0 & 16 & 0 & 0 & 0 & 0 & $37 \pm 50$ & $3 \pm 7$ \\
\hline
\end{tabular}

